\title{
PERSPECTIVES OF SUSTAINABLE \\ COLLABORATIVE MANAGEMENT: \\ A CASE STUDY IN KERINCI SEBLAT NATIONAL PARK, SUMATRA - INDONESIA
}

\author{
Dissertation \\ zur Erlangung des mathematisch-naturwissenschaftlichen Doktorgrades \\ 'Doctor rerum naturalium' \\ der Georg-August-Universität Göttingen \\ im Promotionsprogramm Geowissenschaften/Geographie \\ der Georg-August University School of Science (GAUSS)
}

vorgelet von

Doni Yusri

aus Krui-Lampung, Indonesia

Göttingen 2016 
Betreuungsausschuss:

Prof. Dr. Heiko Faust

Abteilung Humangeographie, Geographisches Institut, Fakultät für Geowissenschaften und Geographie, Georg-August-Universität Göttingen

Prof. Dr. Christoph Dittrich

Abteilung Humangeographie, Geographisches Institut, Fakultät für Geowissenschaften und Geographie, Georg-August-Universität Göttingen

Mitglieder der Prüfungskommission

Referent: $\quad$ Prof. Dr. Heiko Faust

Abteilung Humangeographie, Geographisches Institut, Fakultät für Geowissenschaften und Geographie, Georg-August-Universität Göttingen

Korreferent: Prof. Dr. Christoph Dittrich

Abteilung Humangeographie, Geographisches Institut, Fakultät für Geowissenschaften und Geographie, Georg-August-Universität Göttingen

$\underline{\text { Weitere Mitglieder der Prüfungskommission }}$

Prof. Dr. Ralph Mitlöhner, Burckhardt-Institute Tropical Silviculture and Forest Ecology, Fakultät für Forstwissenschaften und Waldökologie, Georg-August-Universität Göttingen

Prof. Dr. Daniela Sauer, Abteilung Physische Geographie, Geographisches Institut, Fakultät für Geowissenschaften und Geographie, Georg-August-Universität Göttingen

Lukas Giessen, PhD., Abteilung für Forst- und Naturschutzpolitik und Forstgeschichte, Fakultät für Forstwissenschaften und Waldökologie, Georg-August-Universität Göttingen

Dr. Markus Keck, Abteilung Humangeographie, Geographisches Institut, Fakultät für Geowissenschaften und Geographie, Georg-August-Universität Göttingen

\section{$\underline{\text { Tag der mündlichen Prüfung }}$}

Mittwoch, 15.06.2016 
"Kerinci valley is the piece of heaven that fell to earth"

"There's no one branch of tree broken"

(Local Indigenous Proverb) 
Table of contents

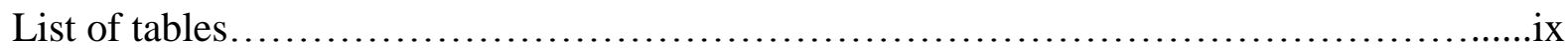

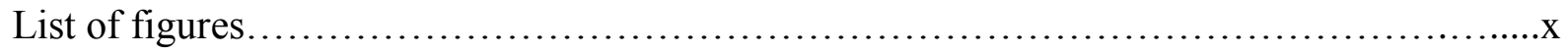

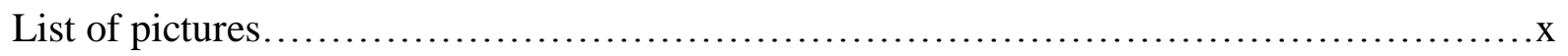

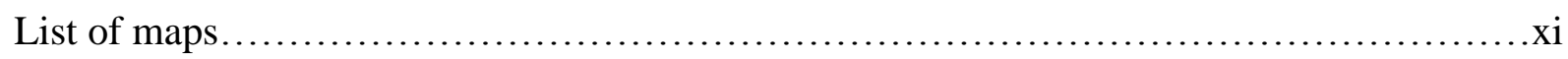

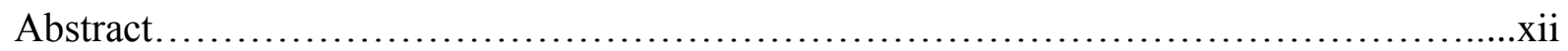

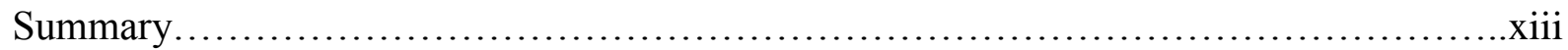

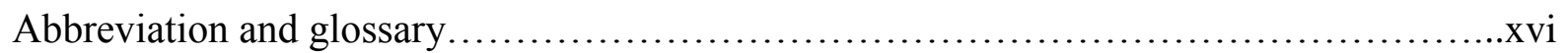

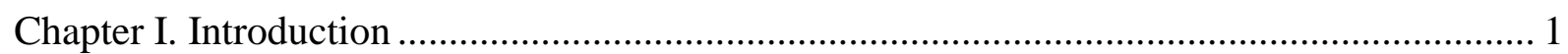

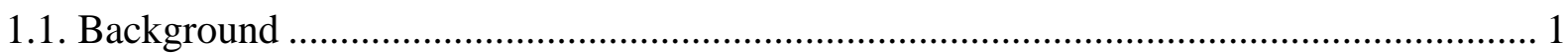

1.1.1. Challengings and problems in preserving protected areas ....................................... 1

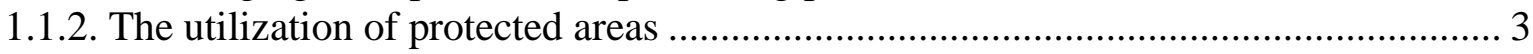

1.1.3. A study on a biodiversity conservation area: Kerinci Seblat National Park .............. 6

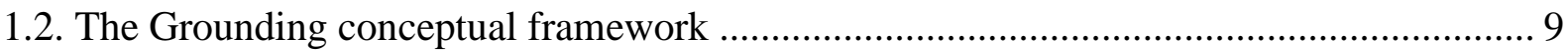

1.3. Formulation of problems and research objectives................................................... 13

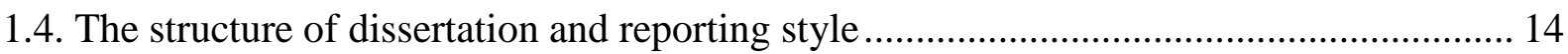

Chapter II. Theoritical Approaches and Conceptual Framework ......................................... 16

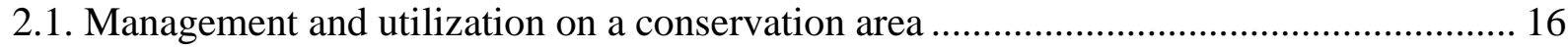

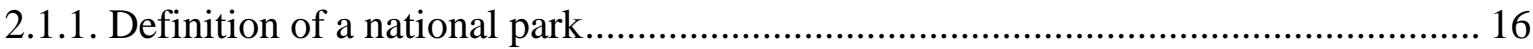

2.1.2. Zoning system as a management pattern of national park..................................... 20

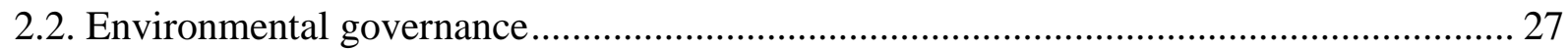

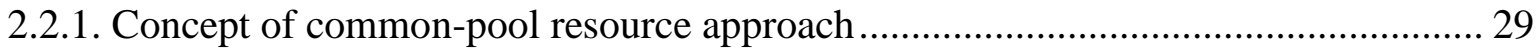

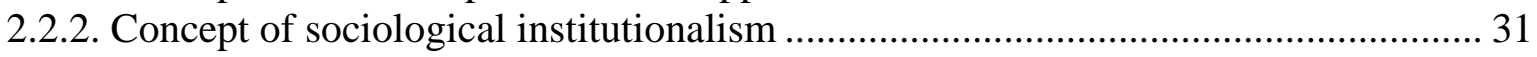

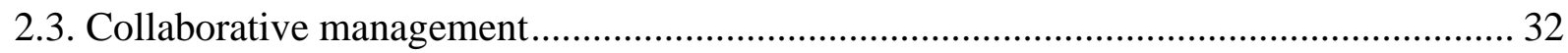

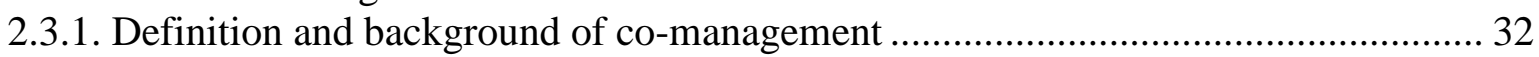

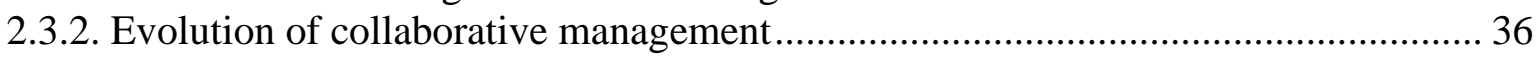

2.3.3. Concept of adaptive collaborative management..................................................... 39

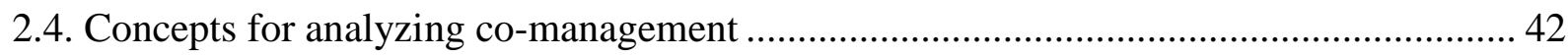

2.4.1. Concept of policy analysis: empowered deliberative democracy ........................... 42

2.4.2. Concept of institutional dimension: participation, power sharing, and process ........ 44

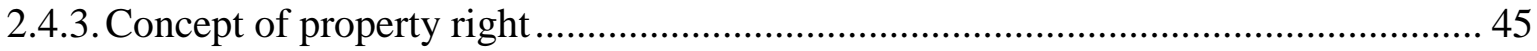

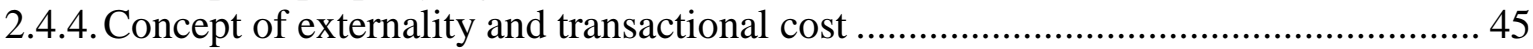

2.4.5. Concepts of sustainability ecotourism .................................................................. 48 


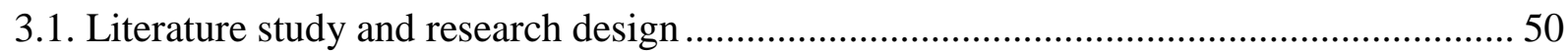

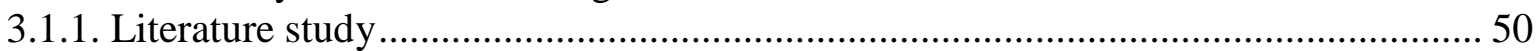

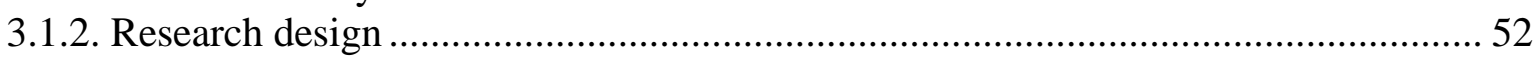

3.2. First fieldwork journey as fitting reasearch approach ............................................... 55

3.3. Setting research villages and procedures selecting respondent ....................................... 57

3.4. Data collection devices determinator for collaborative management .............................60 60

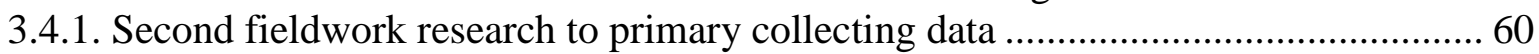

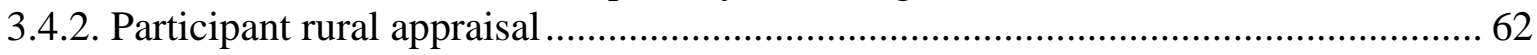

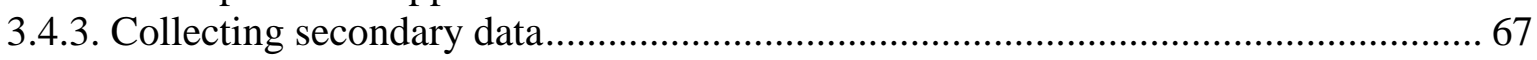

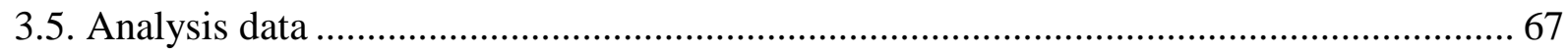

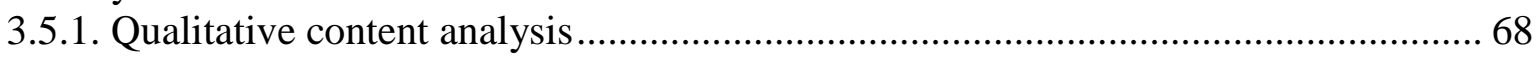

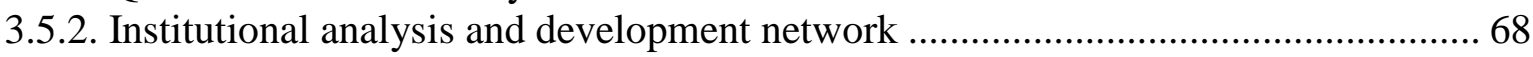

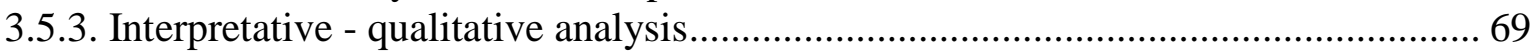

Chapter IV. Research Area and Geographic Characteristics ......................................... 70

4.1. Why has Kerinci Seblat National Park been selected as a research area? ...................... 70

4.1.1. Location and the area of Kerinci Seblat National Park ........................................... 70

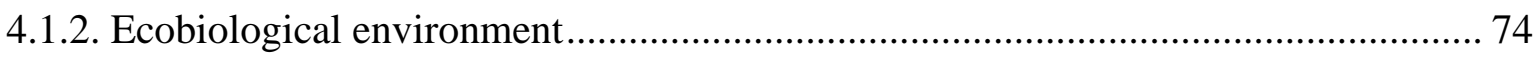

4.1.3. Management of Kerinci Seblat National Park .................................................... 79

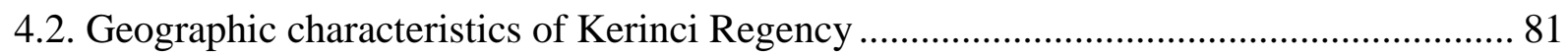

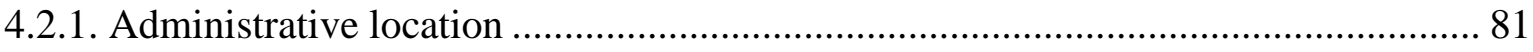

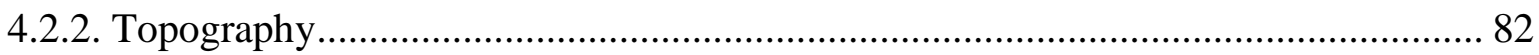

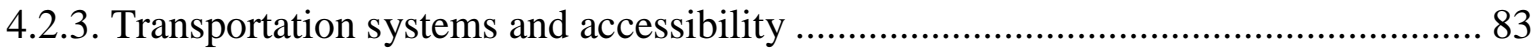

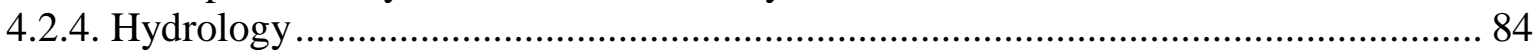

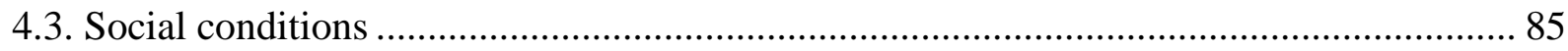

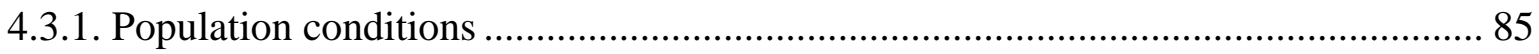

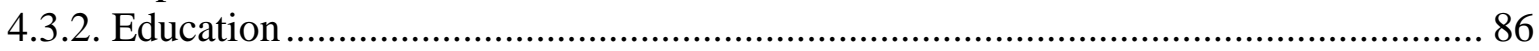

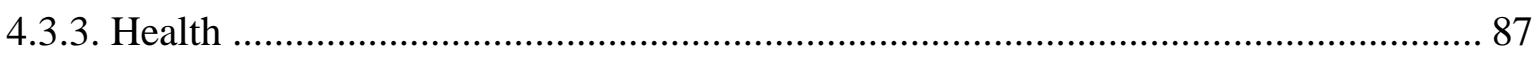

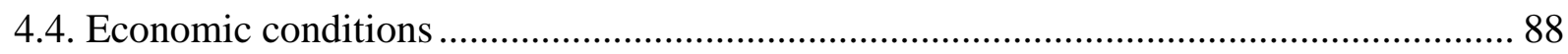

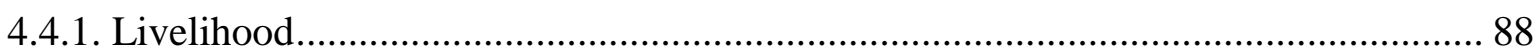

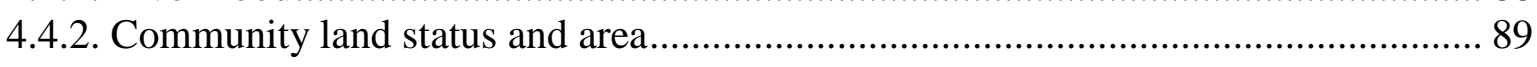

Chapter V. Perceptions and Interactions of Local Community towards the Surrounding Natural Environment: Findings from the Empirical Study ............................. 91

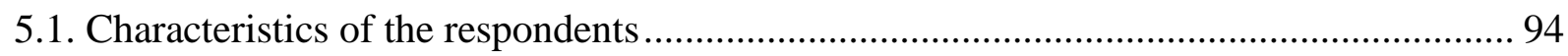

5.2. Findings of the empirical study from the viewpoints of local communities .................... 96

5.2.1. Local community's perceptions and interactions with forest resources, the environment and KSNP

5.2.2. The diverse perspectives of four local communities regarding the utilization of conservation areas 
5.3. Perceptions and interactions of the Lindung Jaya and Pelompek villagers related to natural resources

5.3.1. Livelihoods and horizontal conflicts over land authority.

5.3.2. The change in cultivation patterns regarding farming practices, horizontal conflicts

shifted into vertical conflicts over the Natural Resources Authority

5.3.3. Conservation areas are still polemic for local people.

5.4. Perceptions and interactions of the people in Lempur Tengah and Sanggaran Agung... 109

5.4.1. Customary forest and boundaries

5.5. Lessons learned from the empirical study.

5.5.1. Knowledge about the existence of KSNP.

5.5.2. The KSNP area borders, as well as the settlement and business locations of local residents

5.6. Community interactions with the forest resources, environment and KSNP.

5.6.1. The rights to land authority and management

Chapter VI. The Role of Governmental Agencies in Preserving Natural Resources:

Evidence from the Empirical Study.

6.1. Community and public involvement in forest planning according to the perspectives of the local government.

6.1.1. Community participation in the management of the agroforestry system according to local regulation for forest governance.

6.1.2 Creating indigenous forests to minimize conflicts and to protect the areas ............. 134

6.1.3. Improving communities' livelihoods from the perspectives of the local government.

6.1.4. Water resources as another potential natural resource ....................................... 138

6.1.5. Limited resources on local government.............................................................. 139

6.2. Perspectives of central government for managing the protected area according to the zoning system.

6.2.1. Fundamental law and organizational structure of KSNP .................................... 141

6.2.2. Management authority and utilization of the conservation area in KSNP .............. 143

6.2.3. Zoning system for empowering local people from the perspectives of KSNP ....... 145

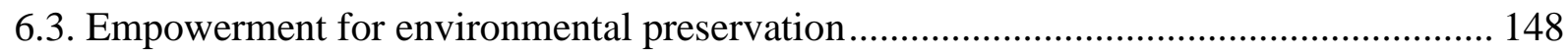

6.3.1. Perspectives of forest policies in the era of decentralization ................................ 148

6.3.2. Challenges for the management of Kerinci Seblat National Park .......................... 149

Chapter VII. Ecotourism as a Driver for Developing the Economy and Conservation Activity

7.1. Contribution of the tourism sector in Indonesia.

7.1.1. Ecotourism as a recent trend to link conservation and poverty alleviation in protected areas.

7.1.2. Ecotourism offers a better method of poverty reduction in areas surrounding national parks

7.2. Lesson from the empirical study: The challenge of the decentralization era for the development of ecotourism in protected areas. 
7.2.1. Perspectives of local people on the development of ecotourism potencies inside and in surrounding regions of the conservation area

7.2.2. History of Kerinci and the indigenous people of Kerinci.

7.3. Developing ecotourism to improve the economy and protect the sustainability of the area

7.4. National design and administration for the development of ecotourism in KSNP

7.5. Local governments efforts to create ecotourism destinations

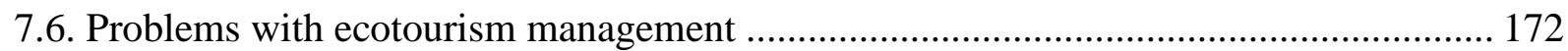

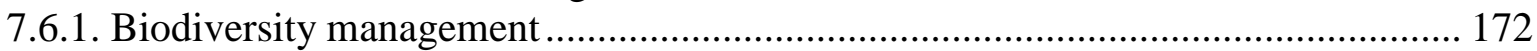

7.6.2. Ecotourism planning in Kerinci Seblat National Park........................................ 173

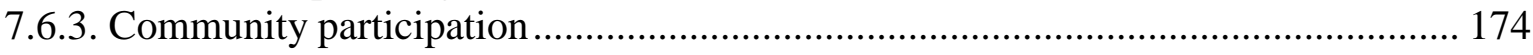

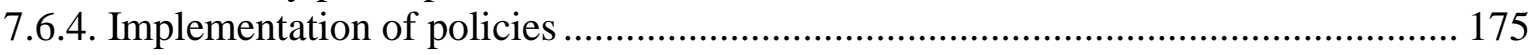

Chapter VIII. Developing Collaborative Management: Modelling, Obstacles and Opportunities for Collective Action among Stakeholders

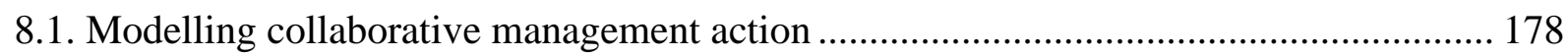

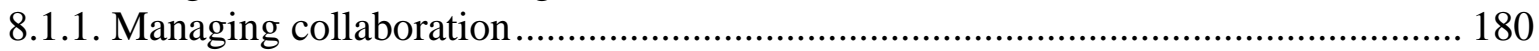

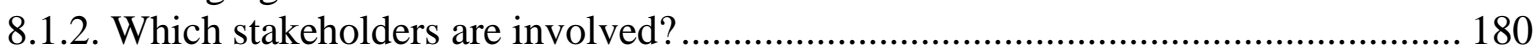

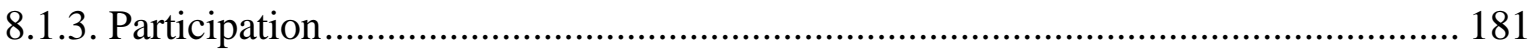

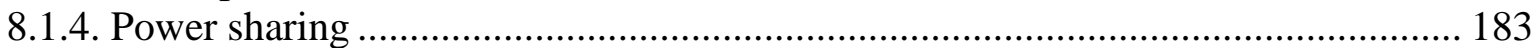

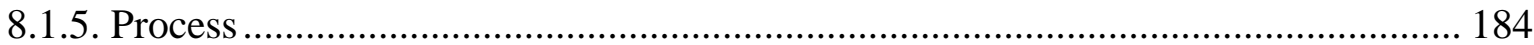

8.2. Obstacles related to developing co-management in Kerinci Seblat National Park

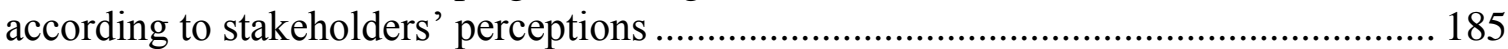

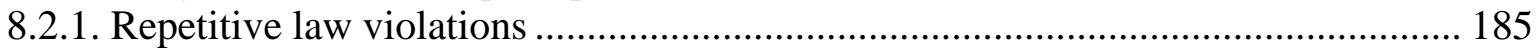

8.2.2. Negative perceptions towards the KSNP authority ......................................... 187

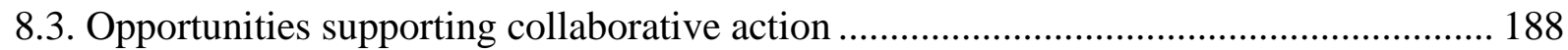

8.3.1. Key success factors to build co-management in KSNP: Perspectives of

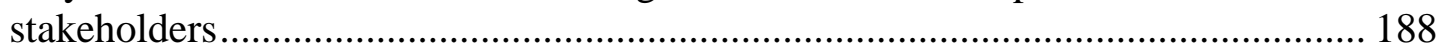

8.3.2. Political and economic development to encourage a co-management .................... 190

8.4. Solutions for conflicts related to protected natural resources management in the KSNP area

8.5. Similar need in the northern and southern regions to remove encroachers

8.6. Considering ecotourism as the most potential factor in collaborations between stakeholders and KSNP management

8.7. The responsible-adaptive co-management as an appropriate strategy

Chapter IX. Conclusion and Recommendation

9.1. Conclusion 


\section{List of tables}

Table 1 Cumulative growth of the protected areas network since 1962 ................................ 5

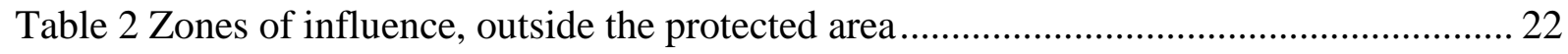

Table 3 Kinds of management zone defined within the protected area and wider zones ........ 23

Table 4 Management zones that may be either inside or outside the protected area ............... 25

Table 5 Definition of environmental governance ............................................................... 27

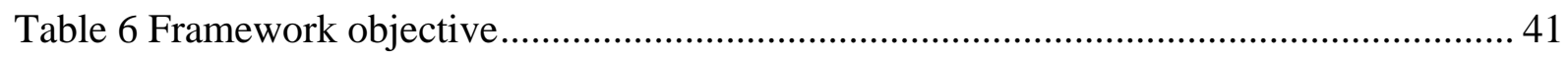

Table 7 Research question, perspectives approaches, and literatures sources ....................... 51

Table 8 Administrative level, stakeholder, research technique, and issued addressed ............56

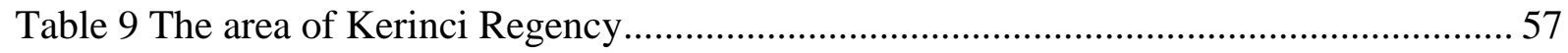

Table 10 The name of selected Sub-district and Village ..................................................... 59

Table 11 Stakeholder, respondents, and number of respondent........................................... 61

Table 12 The coverage area of Kerinci Seblat National Park ................................................ 71

Table 13 The name of rivers (water shed) in each provinces surrounding KSNP ................. 72

Table 14 The detail area of Kerinci Regency based on altitude above sea (in ha) ................. 73

Table 15 Forest cover and the changes in the Regions around KSNP .................................. 74

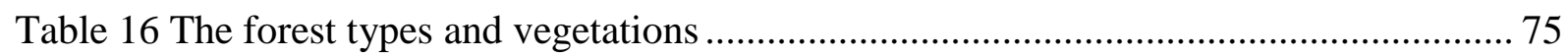

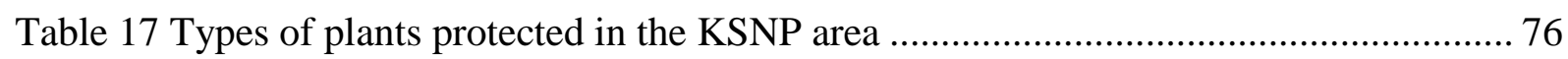

Table 18 Protected animals in the KSNP area of Kerinci Regency ...................................... 78

Table 19 Total education infrastructures and facilities in 2007 by level of education ............ 87

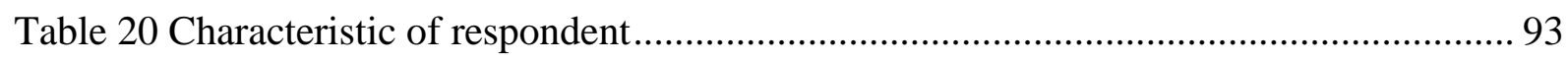

Table 21 Classification of forest areas in Kerinci Regency ............................................. 127

Table 22 Classification of forest areas in Jambi Province .................................................... 128

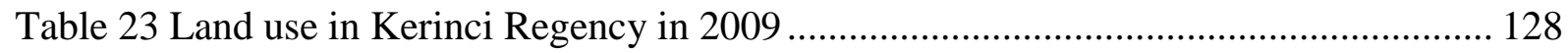

Table 24 Definite customary forests in Kerinci Regency .................................................. 132

Table 25 Proposed customary forest land in Kerinci Regency .......................................... 133

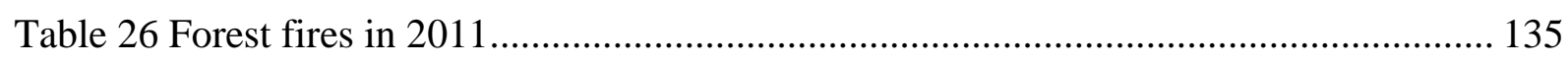

Table 27 Results of security forest operations in Kerinci Regency in 2011 ........................ 136

Table 28 The offices of the KSNP authority and its divisions ........................................ 145

Table 29 Location of tourist destinations in Jambi Province .............................................. 147

Table 30 Ecotourism destinations, attraction types and the organizer ................................. 162 
Table 31 Percentage of successful implementation set by the KSNP authority in 2013 167

Table 32 Tourist destinations in the KSNP conservation area in Jambi Province 168

\section{List of figures}

Figure 1 Evolution of the terrestrial and marine protected area network. 5

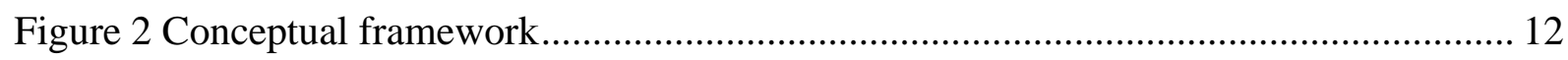

Figure 3 Spectrum of collaborative management …..................................................... 34

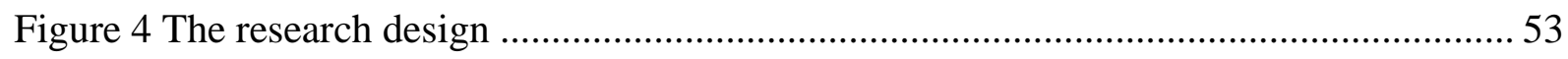

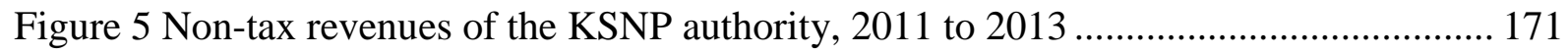

Figure 6 Number of KSNP visitors from 2011-2013 ..................................................... 171

Figure 7 The modelling of responsible-adaptive co-management from the empirical study. 179

\section{List of pictures}

Picture 1 A traditional event of Javanisch community in Kayu Aro Sub-district.................... 63

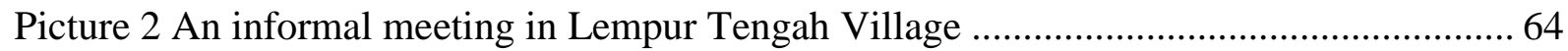

Picture 3 Focus group discussion with local communities located in Lindung Jaya village ... 65

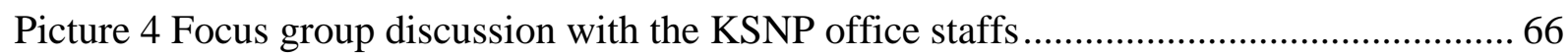

Picture 5 Production activities of local horticulture farmers in Kayu Aro Sub-district........... 95

Picture 6 An agricultural area in the KSNP area located in Gunung Raya Sub-district ......... 97

Picture 7 A cultivated land in the KSNP area located Gunung Tujuh Sub-district ................ 98

Picture 8 Residences in Lindung Jaya and Pelompek Villages........................................... 100

Picture 9 Loading potatoes as part of the farming activities in Pelompek Village ................ 103

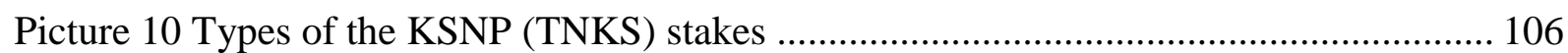

Picture 11 Encroachment area on the slopes of Mount Kerinci (white line) caused by local

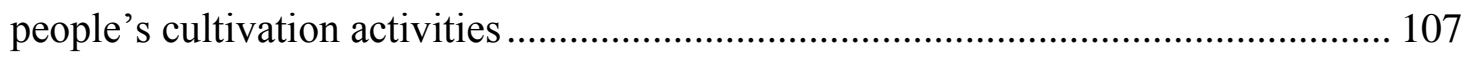

Picture 12 The horticulture-based crops around the cinnamon area .................................... 110

Picture 13 Loading cinnamon as part of agribusiness activities in Lempur Tengah.............. 115

Picture 14 A farmer showing the borders of the state-owned forest in Sanggaran Agung .... 118

Picture 15 Lake Kaco located in the core zone insight KSNP in Lempur Tengah ................ 119

Picture 16 Archaeological heritage of indigenous people in Lempur Tengah ....................... 158

Picture 17 One of traditional dances is performing at Lake Kerinci Festival in 2014 ........... 160

Picture 18 Tea pickers are picking tea leave in the state owned plantation in Kayu Aro ...... 163

Picture 19 The main entrance of Lake Gunung Tujuh located in Pelompek Village............. 165 


\section{List of maps}

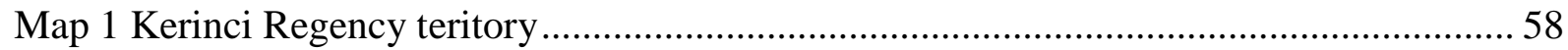

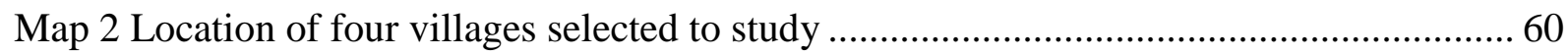

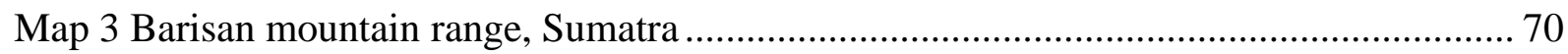

Map 4 Location of the production forest in the community based participation pattern (blue)

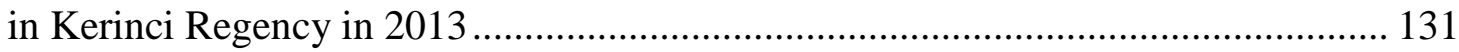

Map 5 Location of indigenous forest of Lekuk 50 Tumbi ................................................ 133 


\begin{abstract}
A conservation area is a natural resource in which management uses the resources based on the principles of protecting and preserving by utilizing wisely and minimizing inflicted damage. Although the damage resulting from conservation forest is smaller than the other forest types. Cooperation among stakeholders should set out from the perspective, delivery, and interaction patterns that are not unilaterally from one of stakeholder members. This research seeks to discover an appropriate collaborative management on the conservation area, especially in the national park area. The study was conducted in four selected villages surrounding Kerinci Seblat National Park where the villages are administratively part of Kerincy Regency. This study shows that there are at least three main actors such as local communities, government agencies and local governments which must manage the region as a collaboration. The pattern of collaborative management is suggested as responsible - adaptive collaborative management, which means that each actor in addition to carrying out its functions according to the agreement as well is responsible for the success of the tasks of the other actors at the same time. Three criteria such as participation, power sharing and process have been used to evaluate the role and function of each actor. In addition, each actor has also been examined with two collaborative management approaches namely the governance theory and the theory of common pool resources. This research proposes the ecotourism sector as a collective action to unite the stakeholders in the context of collaborative management to be sustainable. Running a sustainable collaborative management should start from mutual giving of responsibilities among the actors.
\end{abstract}

Keywords: Conservation area, collaboratiove management, actor, sustainability, responsibility, Kerinci Seblat National Park, Sumatra 


\section{Summary}

One of the most effective ways for preserving forests and biodiversity is to maintain the protected and conservation forests so as not to experience extensive damage and, if necessary, to widen the protected and conservation forest areas. The conservation area is a form of a natural resource in which the management practices of such an area are based on the principles of protecting and preserving by proper utilization and ensuring that minimal damage is inflicted on the area. Conservation activity is linked to preservation, maintenance, sustainable utilization, restoration, and enhancement of the natural environment. Preservation is an effort that is done with consciousness to avoid damages to nature's capacity to selfregenerate. Sustainable utilization is a utilization that is strived for the maintenance of renewable resources for the benefit of present and future generations. Restoration and enhancement is activity which is focused on the recovery of degraded ecosystems into healthier and more sustainable conditions. Conservation is combination of activities with some purposes such as protecting, using natural resources sustainably and restoring nature in different proportions depended on situation and perception.

Kerinci Seblat National Park (KSNP) in Indonesia is a park that gets substantial attention due to the potential of its biodiversity, as well as the fact that is surrounds the homes of people that have inhabited the region long before the forest was dedicated to be a national park. An issue of concern in Kerinci Regency is the use of land, a factor which needs more attention from the local government, the KSNP authority, and local communities. Land use in this region is dominated by conservation land, with an area of 191,819 ha, equivalent to 59.42 percent of the total area of Kerinci Regency. Other land uses are customary forest area $(0.25 \%)$, swamp $(0.02 \%)$, settlements $(0.63 \%)$, sugarcane plantations $(0.45 \%)$, tea plantations $(0.95 \%)$ and the local airport $(0.0004 \%)$. Land use requires more attention in order to anticipate development and population explosions that may have implications on the land usage. Population growth is predicted to be 0.1 percent annually. Therefore, the management of the above areas should be allocated equally so that the productivity of the region continues to grow without damaging or penetrating the conservation zone of Kerinci Seblat National Park.

Determining that a forest conservation area should be considered to be a national park does not automatically ensure the protection of the habitat or biodiversity. The conservation area will likely continue to experience disruption and threats to its sustainability. 
In the case of Kerinci Seblat National Park, one of these threats comes from the people that live in the surrounding area. For decades, residents living in Kerinci Regency have been dependent on the biodiversity in the park. Moreover, many of them still consider the presence of the conservation agency to be unwelcome because the park manager prohibits their use of the area.

This study used the empirical study approach with the main goal is to determine a pattern of appropriate collaboration that can unite stakeholders and work in a collective action. This study was conducted in Kerinci Regency located in KSNP (enclave). Secondary and primary data were collected by some methods such as participant observation, focus group discussion, open discussion, participant rural appraisal, and in depth interview. Data was analysed by qualitative content analysis, institutional analysis and development, and interpretative qualitative technique.

The result of the field study even suggested that this pattern of cooperation should be made among the stakeholders in special the local community, the KSNP authority and the local government in order to reduce the number of cases of land encroachment and conflicts of interest. This idea is known as collaborative management on protected area and provides equal opportunities in terms of power and responsibility sharing to all involved stakeholders. The situation in Kerinci Regency could have been dealt with through a collaborative adaptive management approach. This approach provides equal opportunities in terms of power sharing, gives regulations that allow high levels of participation among stakeholders and provides a sustainable learning process for the stakeholders, which is important since decision-making is a continuous process. This is in accordance with the main principle of adaptive comanagement is power sharing which is the final process, it is not the starting point. How the shared actions among stakeholders are regulated depends on the approach that is developed during the process. However, it must also be realized that the adaptive co-management approach emphasizes the wants and needs of each stakeholder. This means that each involved stakeholder or actor will only think of sustainability in the sense that they will only think about the outcomes which produce results for them. In other words, the adaptive comanagement approach leads to more sustainable actions and it gives opportunities to each stakeholder to maintain their position.

Based on this research, there is a new finding to resolve conflicts among stakeholders in Kerinci Seblat National Park. This study offers an approach called perspectives of responsible-adaptive-collaborative management. This perspective can continuously bridge the interests of multi-stakeholders and binds them to each other infinitely. Moreover, this 
perspective does not merely look at the aspects of process, participation, and power sharing for multiple stakeholders, but it also considers the responsibilities that must be taken by all involved stakeholders. For instance, when the KSNP authority has fulfilled the wants of the local community, the community not only gradually leaves the encroachment area, but they also have developed an understanding of guarding the nature protection program and protecting the area's biodiversity. On the other hand, when the community has followed the wishes of the KSNP authority and leaves the encroachment areas, the KSNP party does not only work with the local government provide aid, or seeds or calves, but it also increases economic prosperity for the local communities to provide long term solutions for economic wealthy.

The responsible-adaptive co-management approach is also believed to be less appropriate because at the end of the program, each party will maintain their original position and follow principles of sustainability: the sustainability of the program and the desire of each stakeholder. In short to enrich the case studies of the KSNP area and perhaps to give solutions for the natural resource management for all involved stakeholders, the researcher once again proposes the concept of responsibility-adaptive co-management. Adaptive co-management is still included as a potential approach because a collective action to compose new institutions for both rules and organization still requires processes, power sharing and participation. The principles are not enough. However, a principle which should be put in place is a responsibility. Moreover, each stakeholder should have one vision, i.e., how the various parties can cooperate interdependently, to be dependent on one another in fulfilling what is wanted and needed by all parties and to ensure collective responsibility. If the principle of responsibility is agreed upon all the actors, the collaborative management will take place sustainably.

Keywords: Empirical study, adaptive-comanagement, collective action, stakeholders, responsibility, sustainability 


\section{Abbreviation and Glossary}

BBTNKS

BSCC

CBRM

COED

Co-management

CPR

DAS

Data Potensi Desa

EDD

FGD

GDP

Hak Hutan Adat

HKM

$\mathrm{HPH}$

HP3M

HPT

HTI

IAD

ICDP

IUCN

JFM

KBWC

KPA

$\mathrm{KPH}$

KSA

KSNP

LTA

NGOs

Pemda

PIR
Balai Besar Taman Nasional Kerinci Seblat/the Kerinci Seblat

National Park authority

the Biological Science Club

community-based resource management

the Commission on Environment and Development

collaborative management

common pool resource

daerah aliran sungai/water resources

the village potential data

empowered deliberative democracy

focus group discussions

gross domestic product

customary forest land right

hutan kemasyarakatan/community forestry

hak pengusahaan hutan/forest concessionnaire holder rights

hutan produksi pola partisipasi masyarakat/ the production forest

of community based participation pattern

hutan produksi terbatas/ limited production forests

hutan tanaman industri/industrial forest plantation

institutional analysis and development

integrated conservation and development program

international union for conservation of nature

joint forest management

Kerinci Bird Watching Club

kawasan pelestarian alam/ the natural preservation area

kesatuan pemangkuan hutan/forest stewardship unit

kawasan suaka alam/ the natural conservation area

Kerinci Seblat National Park

Lembaga Tumbuh Alami (local NGO in Kerinci Regency that

concern to advocate coffee farmer)

non-government organizations

pemerintah daerah/local government

perkebunan inti rakyat/ nucleus estate of smallholders 
RHL

rehabilitasi hutan dan lahan/forest and land rehabilitation

RPJM

rancangan pembangunan jangka menengah/ the medium term development plan

Forum Silaturahmi informal meeting

SIMAKSI surat ijin masuk kawasan konservasi/ a permit to enter the conservation area

SMEs small medium enterprises

UNEP United Nations Environment Programme

UNESCO United Nations Educational, Scientific and Cultural Organization

WWF

WALHI Worldwide Fund for Nature

Wahana Lingkungan Hidup Indonesia/Indonesian Forum for Environment

Warsi Warung Konsultasi Konservasi (local NGO in Jambi province that concerns to advocate community for conserving and protecting natural resources) 


\section{Chapter I. Introduction}

\subsection{Background}

\subsubsection{Challengings and problems in preserving protected areas}

Indonesia is known as one of the greatest biodiversity hotspots in the world (Medail \& Quezel, 1999; Ross, 1999; Manurun, 2002; White \& Martin, 2002; Brooks, et al., 2006; Bellwood \& Meyer, 2009). Hotspots of biodiversity can be meant as areas particularly rich in species, threatened species, rare species, or some combination of these attributes and they can be used for conservation planning (Reid, 1998; Myers, Mittermeier, Mittermeier, Fonseca, \& Kent, 2000; Smith, Kark, Schneider, Wayne, \& Moritz, 2001; Sloan, Jenkins, Joppa, Gaveau, \& Laurance, 2014). There are approximately 49 different types of ecosystems within Indonesian's country. Although Indonesian's land area accounts for only $1.32 \%$ of the total global land area, it contains $10 \%$ of the global plant species, $12 \%$ of mammal species, $16 \%$ of reptile and amphibian species, $17 \%$ of bird species, $25 \%$ of fish spieces, and $15 \%$ of insect species (Manurun, 2002). One of the biodiversity focuses in Indonesia is forest resources and protected areas (Linkie, et al.,2008). The World Bank (2006), with cited The Indonesian government, claims that Indonesia has a forest area of 127 million hectares, while according to Nurrochmat, Darusman, \& Ruchjadi (2014), the country controls a forest area of 136 million hectares which is equivalent to approximately two-thirds of Indonesia's total land area. Current laws and regulations indicate that Indonesian forests should be utilized as a source of economic benefit for all Indonesian citizens, while protecting the biodiversity and valuable ecosystems found in these forests (Bank, 2006; Eilenberg, 2015).

An ever-increasing human population affects the demand for the provision of goods and services sourced from forest ecosystems (McNeely, 1994; Austin, et al., 2014). Human demand for a diverse range of goods and services produced from forests have caused problems in the forestry sector (Schwarze, et al., 2007; Young, et al., 2007). For example, the annual demand for wood which is conventionally produced by forests is approximately $3 \%$, exceeding the growth rate of global forest production of $1.5 \%$ per year. The impact of human activities on the demand for goods and services sourced by forests include damage to the forest ecosystem and a decrease in the amount of forest area itself (Arnold \& Pe'rez, 2001).

In Indonesia alone, approximately 1 to 2 million hectares of forest functions are converted every year, primarily in the areas of forest production and conversion (The World Bank, 2006; Wicke, Sikkema, Dornburg, \& Faaij, 2011). Production and conversion forests, 
specifically, are intended to be used for economic gain (Irawan, Tacconi, \& Ring, 2013). The data of the World Bank (2006) indicated that Indonesian production forests experienced nearly a 30 percent deforestation in 2000, indicating that a forest crisis has occurred in Indonesia. Regarding to another report, Margono, Potapov, Turubanova, Stolle, \& Hansen (2014) have concluded that a spatially and temporally explicit Indonesian Quantification of primary forest loss which totalled over 6.02 Mha from 2000 to 2012 and increased on average by 47.600 ha per year. Furthermore, they stated that annual primary forest loss in Indonesia (0.84 Mha) was estimated to be higher than in Brazil (0.46 Mha) in 2012. The primary causes of this crisis are illegal forest conversion and forest clearing without regard to the forest cover through not selectively cutting, as well as reforesting (Barr, Barney, \& Laird, 2014; Indarto, Kaneko, \& Kawata, 2015; Appanah, 2016). The forest cover is an indicator of a forest function (Tscharntke, et al., 2011) so if the forest cover does not peak at $28 \%$, for instance, the forest is not going to be sufficient for the economy, environmental or social life function (The World Bank, 2006). Of the four types of forest land classification regulated by the Indonesian Forestry Law of 1999 (article 6) such as production forest, conservation forest, protection forest and conversion forest, are considered to be the most rapidly changing forest areas based on some studied are production forest and conversion forest. Although it is not so rapid as production forest and conversion forest, conservation forest and protected forest areas are also experiencing deforestation estimated at a rate of 20 percent annually.

Among the primary causes of forest loss and degradation are the activities of smallscale businesses and large corporations, and political forces (Sodhi, 2010; Giessen, 2011; Khan, 2014 ; Indarto, Kaneko, \& Kawata, 2015; Gatto, Wollni, \& Qaim, 2015). The forestdamaging activities involve not a single actor, but the activities are a range of actors, from small-scale farmers, local governments, large plantation businessmen, timber processing business entrepreneurs and even mine entrepreneurs (Dauvergne, 1994; Chomitz, 2006; Obidzinski \&.Chaudhury, 2009; Barkmann, et al., 2010; Stibig, Achard, Carboni, Raši, \& Miettinen, 2014; Abood, Lee, Burivalova, Garcia-Ulloa, \& Koh, 2015). Agricultural expansion also contributes to forest loss (Morton et al., 2008; van der Werf et al., 2010; Stibig, Achard, Carboni, Raši, \& Miettinen, 2014). The expansion of oil palm plantations is a large factor (Lee, et al., 2014; Hein, et al., 2015) and one which requires greater forest clearing than that by small-scale farmers (Laurance, Sayer, \& Cassman, 2014; Abood, Lee, Burivalova, Garcia-Ulloa, \& Koh, 2015). Moreover, oil palm plantations are supported by a permit issued by the central government, as well as local governments (Sodhi et al., 2004; Frtzherbert, 2008; Carlsson, 2012). The high population on density areas around the forests tend to have high rates of deforestation as well, indicating a positive correlation between the 
population density and deforestation. Forest fires also contribute to deforestation and degradation, especially in the dry season when many forest areas are vulnerable to fire hazards (Davies \& Unam, 1999; Raymond et al., 2007; Morton et al., 2008; van der Werf et al., 2010).

In addition to the above factors, some of the following activities also threaten forest areas such as road construction, mining, the need for energy sources, and economic and political conditions (Sodhi et al., 2004; Adiwibowo, Shobudddin, Savitri, Syaf, \& Yusuf, 2008; Sodhi, 2010). In the past, Indonesia experienced forest damage and threats through the transmigration program (Gatto, Wollni, \& Qaim, 2015). The transmigration program moved more than 2.5 million people from Java to regions outside Java between the 1970s and the 1990s. The program resulted in the clearing of forest areas for residences, cultivated land and individual yards. Through the program, a migrant household was required to have at least two hectares of land. Whether or not it is fully realized, the transmigration program has resulted in significant loss of biodiversity and other forest resources throughout Indonesia (The World Bank, 2006).

\subsubsection{The utilization of protected areas}

Currently, issues related to natural resources utilization, especially regarding biodiversity and environmental services, has been of critical importance with respect to sovereignity, profit sharing and fairness (Hilman, 2001; Miranda, 2012; Gross-Camp, 2012). Indonesian biodiversity is a national asset to the nation, indicating that the natural biodiversity of plants, animals, microorganisms and genetic content of the unitary structure is part of a complex and dynamic environment (Gillison \& Liswanti, 2004; Allen, 2008; Alikodra, 2013). Therefore, the utilization of biodiversity lends extensive services and opportunities to supporting humanity and economic development (Berkes, 2007; Sayer et al., 2012; Alikodra, 2013).

Worldwide, approximately 50 million hectares of land area have been categorized as being protected areas and forest conservation areas, watersheds and biodiversity hotspots, 20 million hectares of which have been categorized as being under conservation and biodiversity protection (The World Bank, 2006). Indonesia has a land area of 187.9 million hectares, with 143 million hectares designated as state forest land, 16\% being comprised of protected forests, $11 \%$ conservation forests, $14 \%$ limited production forests/Hutan Produksi Terbatas (HPT), 19\% permanent production forests, 12\% converted forest land and $28 \%$ standard forest area (Verbist, Putra, \& Budidarsono, 2005; Suharjito, 2013). Local governments manage about 30 million hectares of critical land for conservation as part of protected forest. 
Land which is classified as protected forest is based on criteria such as slope, soil, rainfall and altitude but the classification is not on criteria directly linked to watersheds (Daerah Aliran Sungai/DAS). Millions hectares are managed by the agroforestry system, which contributes to biodiversity conservation and environmental services such as hydroelectric resources and agriculture (Verbist, Putra, \& Budidarsono, 2005).

In an effort to support the management of protected areas, the Indonesian territory is divided into three bio-geographical regions, with each having a diverse range of habitats, altitudes and climate zones. A bio-geographical region is an area that shows patterns of the biological spread of flora and fauna. In Indonesia, the bio-geographical regions accounted for are Sunda, Sahul and Wallacea. The Sunda (Oriental) and Sahul (Australia) regions are the main bio-geography, while the Wallacea is comprised of a combination of Sunda and Sahul bio-geography. Java, Sumatra, and Borneo are classified as part of Sunda and affiliated with the Asian region. Aru Islands and Papua as parts of the Sahul region (Australia-Indonesia biogeography). Wallacea includes Sulawesi, Maluku and Nusa Tenggara (Sodhi et al., 2004; Tokuda \& Yukawa, 2007; Supriatna, 2014). Seven major bio-geographical areas have been identified in Indonesia, e.g., Sumatra, Java, Bali, Borneo, Sulawesi, Sunda, Moluccas and Irian. The major bio-geographic regions are further divided into sub-biogeographical regions based on its individual flora and fauna. National park classification is also based on the particular species found in a given region, or ecosystem, or the uniqueness and scenery that needs to be protected, along with the uniqueness of a region on a national level (Supriatna, 2014).

Utilization of natural resources should consider the following conservation principles for instance protection, preservation, proper utilization and the minimization of negative impacts (Alikodra, 2013). In the previous section, it was stated that a national park is a nature conservation area or protected area which is dedicated to protecting the region and conserving biodiversity for educational, research and natural recreation purposes. Since 2013, the Indonesian government has established 50 national parks in both land and sea areas. This serves as a reflection of the seriousness of the government's efforts in preservation and management of biodiversity in Indonesia, with total conservation areas accounting for 15 million hectares. The function of conservation areas such as national parks is to protect germplasm and to prevent flooding, erosion, and landslides. The most recent national parks that have been established by the government are Wakatobi Marine National Park in Southeast Sulawesi, Ciremai Mountain National Park in West Java, Raja Ampat National Park in West Papua and Mekongga National Park in Southeast Sulawesi (Alikodra, 2013). The complete list of national parks in Indonesia can be found in Appendix 1. 
One of the most effective ways of preserving forests and biodiversity is through maintaining the protected and conservation forests to minimize extensive damage (Chape, Harrison, Splading, \& Lysenko, 2005). A conservation area is a natural resource in which management uses the resources based on the principles of protecting and preserving by utilizing wisely and minimizing inflicted damage (Alikodra, 2013; White, et al., 2014). International Union for Conservation of Nature (IUCN) defines protected area as "'a clearly defined geographical space, recognised, dedicated and managed, through legal or other effective means, to achieve the long-term conservation of nature with associated ecosystem services and cultural values"' (Deguignet, et al., 2014). Table 1 presents cumulative growth of the protected areas network since 1962 and Figure 1 shows evolution of the terrestrial and marine protected area network.

Table 1 Cumulative growth of the protected areas network since 1962

\begin{tabular}{|c|c|c|}
\hline Year & Number of sites & Total area protected, (km2) \\
\hline 1962 & 9,214 & $2,400,000$ \\
\hline 1972 & 16,394 & $4,100,000$ \\
\hline 1982 & 27,794 & $8,800,000$ \\
\hline 1992 & 48,388 & $12,300,000$ \\
\hline 2003 & 102,102 & $18,800,800$ \\
\hline 2014 & 209,429 & $32,868,673$ \\
\hline
\end{tabular}

Source: Deguignet et al., 2014

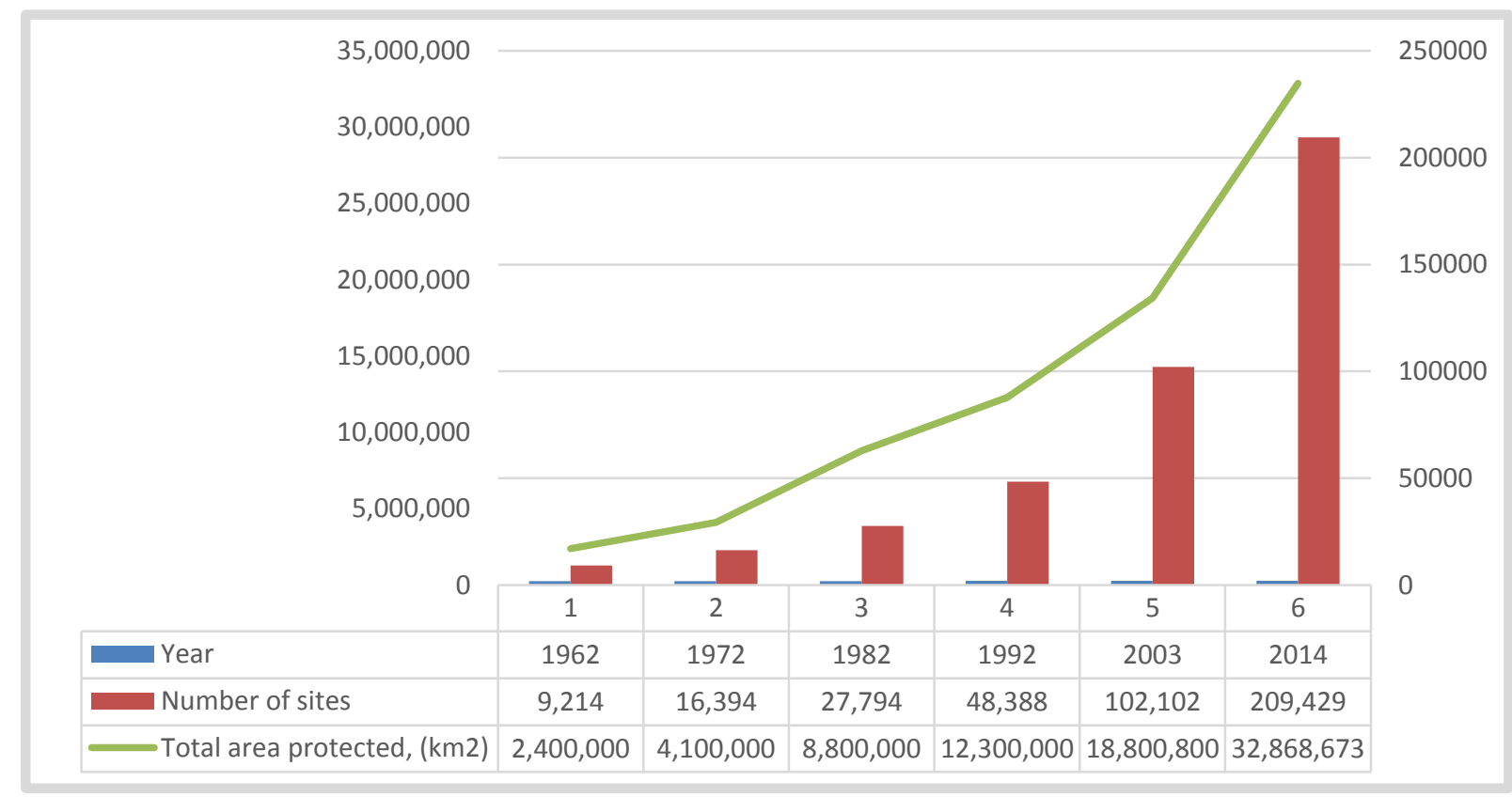

Source: Deguignet et al., 2014

Figure 1 Evolution of the terrestrial and marine protected area network 


\subsubsection{A study on a biodiversity conservation area: Kerinci Seblat National Park}

One of the most effective ways for preserving forests and biodiversity is to maintain the protected and conservation forests so as not to experience extensive damage and, if necessary, to widen the protected and conservation forest areas (Murniati, 2001; Sodhi et al., 2004; Gaston, Jackson, Cantú-Salazar, \& CruzPiñón, 2008; Wilson, et al., 2010; Phalan, et al., 2013; Sloan, Jenkins, Joppa, Gaveau, \& Laurance, 2014). The conservation area is a form of a natural resource in which the management practices of such an area is based on the principles of protecting and preserving by proper utilization and ensuring that minimal damage is inflicted on the area (Mittermeier, Myers, Thomsen, Fonseca, \& Olivieri, 1998; Saunders et al., 2001). Conservation activity is linked to preservation, maintenance, sustainable utilization, restoration, and enhancement of the natural environment. Preservation is an effort that is done with conscious to avoid damage to nature's capacity to self-regenerate. Sustainable utilization is a utilization that is strived for the maintenance of renewable resources for the benefit of present and future generations. Restoration and enhancement is activity which is focused on the recovery of degraded ecosystems into healthier and more sustainable conditions. And, conservation is combination of activities with some purposes such as protecting, using sustainably and restoring nature in different proportions depended on the situation and the perceptions (Borrini-Feyerabend \& Hill, 2015).

Kerinci Seblat National Park in Indonesia is a park that gets substantial attention due to the potential of its biodiversity, as well as the fact that it surrounds the homes of people that have inhabited the region long before the forest was dedicated to be a national park (Aumeeruddy, 1994; Werner, 2001; Adiwibowo, Shobudddin, Savitri, Syaf, \& Yusuf, 2008; Wood, Sheil, Syaf, \& Warta, 2014). The Park is stretched across four provinces and nine regencies (Government of Kerinci Regency, 2009; Blouch, 2010). Of these nine regencies, Kerinci Regency is of particular interest and is the site of this study. The regency of Kerinci has a total land area of 332,842 ha and is composed of 16 smaller sub-districts (Government of Kerinci Regency, 2009).

An issue of concern in Kerinci Regency is the use of land, a factor which needs more attention from the local government (Blouch, 2010; Wood, Sheil, Syaf, \& Warta, 2014). Land use in this region is dominated by conservation land, with an area of 191,819 ha, equivalent to 59.42 percent of the total area of Kerinci Regency. Other land uses are customary forest area $(0.25 \%)$, swamp $(0.02 \%)$, the local airport $(0.0004 \%)$, sugarcane plantations $(0.45 \%)$, tea plantations (0.95\%) and settlements (0.63\%) (Government of Kerinci Regency, 2009). Land use requires more attention in order to anticipate development and population explosions that 
may have implications on land usage (Linkie, Dinata, Nofrianto, \& Leader-Williams, 2007). Population growth is predicted to be 0.1 percent annually. Therefore, the management of the above areas should be allocated equally so that the productivity of the region continues to grow without damaging or penetrating the conservation zone of Kerinci Seblat National Park (Murniati, 2001; Adiwibowo, Shobudddin, Savitri, Syaf, \& Yusuf, 2008; Blouch, 2010).

Determining that a forest conservation area should be considered to be a national park does not automatically ensure the protection of the habitat or biodiversity (Manullang, 1999; Linkie, 2008; Linkie, 2010). The conservation area will likely continue to experience disruption and threats to its sustainability (Blouch, 2010). In the case of Kerinci Seblat National Park, one of these threats comes from the people that live in the surrounding area (Murniati, 2001 ). For decades, residents living in Kerinci Regency have been dependent on the biodiversity in the park (Linkie, Smith, Zhu, \& Leader-Williams, 2007). Moreover, many of them still consider the presence of the conservation agency to be unwelcome because the park manager prohibits their use of the area (Manullang, 1999; Bank, 2006).

From 1995 to 2002, Kerinci Seblat National Park was introduced to a community empowerment project, namely the Integrated Conservation and Development Program (ICDP), by the World Wildlife Funding (WWF) (Hughes, 2001; Wood, 2014;). Principally, this ICDP project offered development programs for the local community in order to improve their overall welfare. Eventually, the local community would abandon the necessary activities resulting in the disruption of the preservation of biodiversity (Hughes, 2001). This is in contrast to the expectation that the ICDP project would persuade the local community to meet their needs from other revenue sources. Furthermore, this project also outlined several activities could have been acceptable in the eyes of the local community, yet many individuals continued their involvement in activities that disturbed the area's biodiversity conservation efforts. Ultimately, the project was determined to have failed in its efforts to build awareness within the local community that would eventually lead to the abandonment of disruptive activities. The failure of this project is due to the nature of top-down project design (Hughes, 2001; Wood, 2014; Linkie, 2014). Other factors may have made failure such as size and complexity of the project, nature of the funding, bureaucratic constraints, the ICDP took place decentralization period, which led to a breakdown in law for the natural resource-use sector and increased illegal logging, and The ICDP village projects varied considerably in terms of their conservation linkages (Linkie, Smith, Zhu, \& Leader-Williams, 2007).

Although the damage resulting from conservation forest is smaller than the other types of areas such as production forest and conversion forest areas, collaboration with local communities to maintain and preserve the conservation area is a necessity and should be 
continuously carried out (Linkie, Smith, Zhu, \& Leader-Williams, 2007 ; Pearson \& Dare, 2014). Collaboration among stakeholders, especially collaborations involving local communities, should set out from the perspective, delivery, and interaction patterns that are not unilaterally from one of stakeholder members. Alit is important to note, however, that the wisdom and knowledge of local communities are often very helpful to maintain and protect resources within the conservation area from various threats and harassment (Indrawan, Lowe, Sundjaya, Hutabarat, \& Black, 2013; Campbell, Kartawijaya, Yulianto, Prasetia, \& Clifton, 2013).

Borrini-Feyerabend (1996) states ',Co-management or collaborative management, often referred to as participatory management, joint management, shared-management, multistakeholder management, or round-table agreement is a management form that accommodates the interests of all parties with the cooperation mechanism, which is driven by the recognition of the inherent right of each party, in order to achieve a common goal, thus allowing all parties can participate to share authority, responsibility and benefits of the management process'. So far, many people have attempted to study and link the collaboration among stakeholders based on the existing differences, it is also necessary, however, to carry out collaboration among stakeholders based on the differences and similarities that exist in order to manage a national park, in this case Kerinci Seblat National Park. The cooperation should follow the principles of collaborative management, namely the willingness, equality and mutual trust, active participation, and a commitment to share with institutional support (Wiratno, Indriyo, Syarifudin, Kartikasari, \& Kartikasari, 2001). For the current analysis, Kerinci Seblat National Park and Kerinci Regency are chosen as the study site for several reasons:

(1) Kerinci Seblat National Park is one of three major national parks in Indonesia that has a large range of biodiversity.

(2) Kerinci Seblat National Park is one of the two national parks in Indonesia that has been introduced to a community empowerment project, namely the Integrated Conservation and Development Program.

(3) Kerinci Seblat National Park has ecotourism potential which can be jointly managed by local government, the park authority and local communities, with support from outside stakeholders.

(4) Kerinci Regency is a district surrounded by the national park and continues to grow with respect to development and population increases. These factors will ultimately affect the existence of Kerinci Seblat National Park. 


\subsection{The Grounding conceptual framework}

Before any further discussion, it is important to mention the findings of other studies that have been done related to natural resource management, the development of collaborative management, and problems that arise as a result of the announcement of the Kerinci forest as the National Park. Conceptually, this study attempts to determine the patterns of appropriate collaboration that can unite stakeholders in the area around Kerinci Seblat National Park (KSNP), particularly between local communities and government agencies. The first aspect which must be determined is the perspectives of various stakeholders regarding the use and management of natural resources in surrounding areas. Second, it is important to determine which party is more dominant with regards to the pattern of relationships between the stakeholders. Regions around the protected preservation and conservation areas, such as national parks, are vulnerable to conflict between local communities and conservation manager (Aumeeruddy, 1994; West, Igoe, \& Brockington, 2006; Andrade \& Rhodes, 2012; Vedeld, Jumane, Wapalila, \& Songorwa, 2012).

The main issue, when considering these perspectives and relationships, is the encroachment of stakeholders, whether it be communities, organizations or other users, into protected forest areas (Vodouhê, Coulibaly, Adégbidi, \& Sinsin, 2010; Winberg, 2010). Furthermore, it is important to figure out why there is a tendency for local communities, the actor who is most often suspected as being the encroacher, into protected forest areas, despite knowledge of the legal consequences of these offenses (Lambin, et al., 2014; Bennet \& Dearden, 2014). It is then relevant to figure out how government agencies are supposed to respond to these problems. In other words, each party will see the other parties as external factors which affect the existence of these protected-natural resources. For local people, the forest is not only viewed as a place to meet the communities' needs, but the forest is also seen as an integral part of their lives and has been perceived as such for generations (Purwanto, 2005; DeFries, Hansen, Turner, Reid, \& Liu, 2007; Karki, 2013). Government agencies, on the other hand, see forests, especially conservation and protected forests, as an area containing biodiversity (Young, et al., 2013). In consideration of these differences, it is necessary for the region to be protected and preserved for the sake of human survival, as well as the maintenance of biodiversity (Nelson et al., 2009; Simberloff, et al., 2013; Powel, et al., 2013). Efforts to resolve disputes and build collaborative actions have been, and will remain to be, continuously carried out by various parties including local communities and the conservation area managers (Birner \& Mappatoba, 2002; Burkard, 2007). 
The next problem is related to the government and local communities having their own views and their own methods for managing and maintaining natural resources (Robinson, Holland, \& Naughton-Treves, 2014). This includes natural resources in the conservation area, so the question arises as to when should collaboration between communities and governments occur, and how is that collaboration developed (Buckles, 1999; Schusler, Decker, \& Pfeffer, 2003; Armitage, 2005; Engel, Palmer, \& Pfaff, 2013). Moreover, there are contradicting points of view that are associated with the varying positions of users and managers. The government is a party that has the legal power to preserve (de jure), to protect conservation areas and to penalize violators (Nurrochmat, Darusman, \& Ruchjadi, 2014). If this is done without some degree of collaboration with other parties, then most conservation areas will result in vertical conflict. On the contrary, the local people who have lived in the area for many years (de facto) may see it as a threat when they are suddenly discouraged from living in a newly declared protected area, further leading to conflict (Engel, Palmer, 2013).

It is relevant to determine what type of co-management is the most efficient and when should collaboration management being. These questions provide an opportunity to conduct research regarding the needs and desires for all involved stakeholders. It is possible that a solution can be found which will lead to the local community and the government reaching a compromise. On the other hand, the solution may be that the local community needs to follow the government-set objectives regarding the utilization and management efforts of protected areas. It is also possible that the solution is to embrace two different desires while implementing a new institution in the form of rules that must be obeyed by both. However, these statements are still within the framework of the hypothesis and provisional estimates.

To answer the above questions, as well as to achieve the objectives of this research, it is necessary to refer to some theories or perspectives from previous studies that have been referenced during this research. Theory and perception that is used is that introduced by the common pool resources-based perspectives (CPR-based) is, as well as theory introduced by the governance-based perspectives (Sandström, 2009). Theories have been used and improved over time to conduct research related to the co-management arrangement of communities and natural resources. Collaborative efforts such as assistance, funding and project development are utilized as a form of compensation for the local community. Admittedly, protests against such efforts are generally the result of negative perceptions and interactions, as well as misunderstandings related to culture and the property rights of local communities. Therefore, numerous studies have been done in an effort to understand the differences between the CPR perspective and the governance perspective. Moreover, these differences are examined in the 
present study, particularly with regards to whether the convergence among these groups can produce an effective cooperation in the form of collaborative management.

In the context of Indonesia, Purwanti (2008) explains that the concept of collaboration in the natural reserve and conservation areas is actually stated in the Indonesian Regulation of the Minister of Forestry No.P.19/2004. Here, it is mentioned that collaborative management is intended to help the effectiveness and usefulness of management efforts in these areas. Thus, the consenting parties must prioritize the principles of mutual respect and benefits. Kerinci Seblat National Park (KSNP), one of two national parks in Indonesia, is part of a collaboration effort, namely the Integrated Conservation and Development Program/ICDP (Hughes \& Flintan, 2001), but the program did not lead to the expected results and, overall, has been considered a failed attempt.

A national park management aims to preserve biodiversity, improve the welfare of local communities and enhance the quality of human resources. Some valid Indonesian government laws and regulations emphasize that the national park management efforts are related to collaborations with local communities that are conducted by the government. In an effort to implement these valid policies and regulations, the central government established the national conservation agency. The patterns of research conducted thus far have focused more on divergences in perceptions, participation and activities amongst stakeholders. The current study, however, emphasizes how the existing divergences can be collaborated upon through the development of similar perceptions, participation and activities by both the local community and various stakeholders.

KSNP has been delegated as a conservation area, with management efforts aiming to maintain the advantages related to biodiversity, through the protection of the ecosystem, preservation of germplasm diversity, and ensuring the utilization of environmental services by local communities (Cernea \& Schmidt-Soltau, 2006). KSNP was designated as a conservation area long after the local communities had already established its livelihood there, generating various divergences and conflicts with the local government after the establishment of the park. The limitation of land use placed on the community in an effort to enhance community welfare through a variety of agricultural and forestry activities has become a problem in itself. On the one hand, the community needs the extension of land to continue on with economic activities and their settlements. On the other hand, due to valid legislation, the KSNP manager have made strides towards catching community members and other stakeholders for improperly using the protected area. This is a classic problem that generally occurs with parties involved in the protection of forests or national parks in Indonesia. The opportunity to build strong collaborations is beneficial for the ecotourism sector, but even this poses a 
problem because some of the ecotourism points lie wit hin the protected area, thus leading to additional complexities within the framework of the area management. Figure 2 shows the research framework and explains the steps needed to formulate the research topic, this is followed by the sub-topic related to various perspectives in this study.

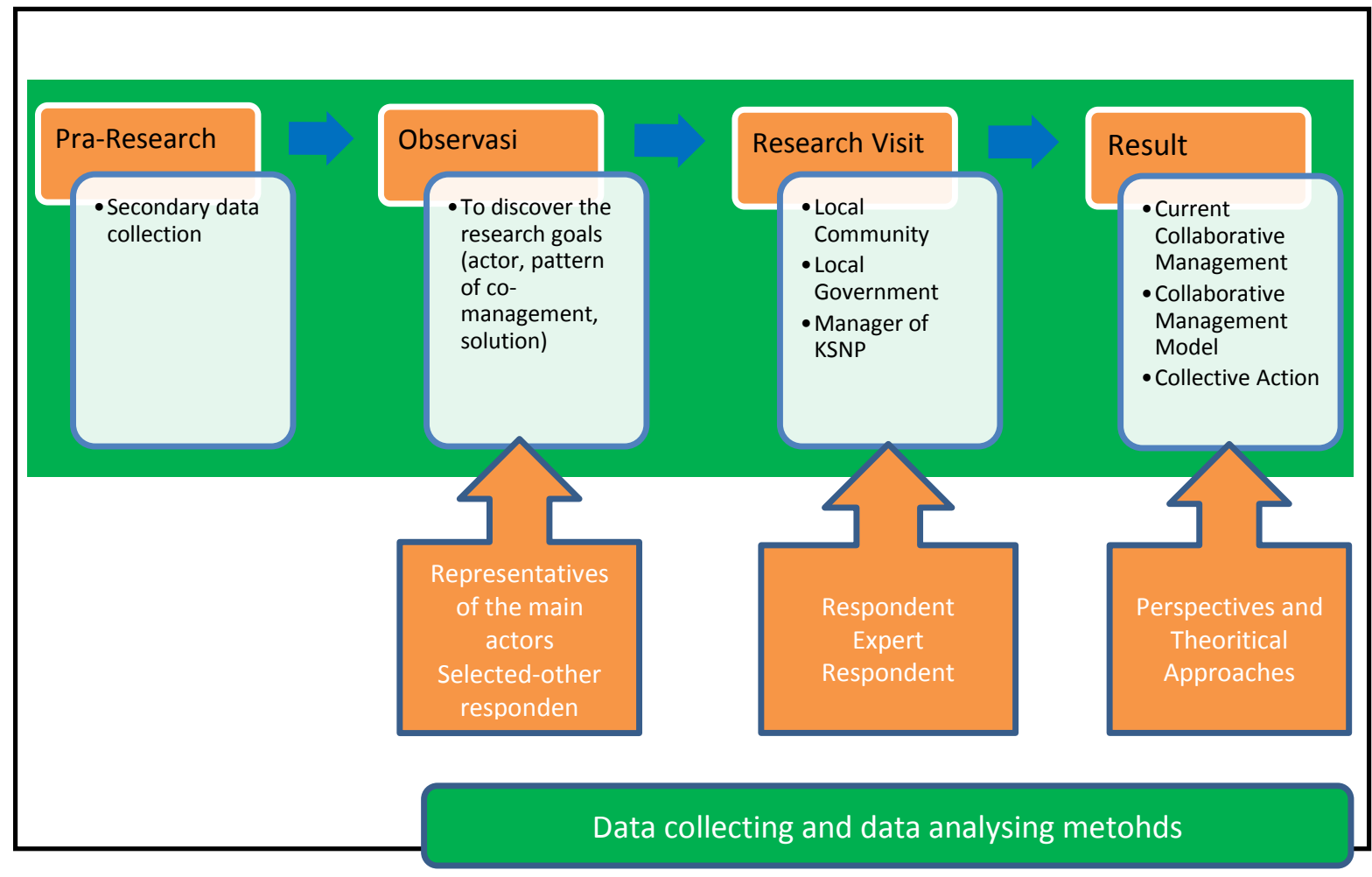

Figure 2 Conceptual framework

The conceptual research framework was initially completed by collecting secondary data related to relevant literature. Two steps were taken to gather the data: 1) Searching through relevant literature sources and grouping the literature according to data types. These secondary data sources were collected from literature made available by universities, study centers, national and local government reports, non-government organizations, and statistics bureaus. The second step of the data collection process was gaining an understanding of the research perspectives in regards to preservation areas and stakeholder interactions. There are three perspectives within the research: (1) Perspectives related to the institutional dimension, which covers participation, process and interaction (Sandström, 2009). This perspective was used to analyze stakeholders' relationships; (2) Perspectives of economic and environmental policies and interactions among governments, local people and the environment; (3) Perspectives of adaptive collaborations in an effort to find a pattern for adaptive-collaboration in regards to collaborations made among stakeholders to utilize and preserve conservation 
areas. From these perspectives, the study of collaborative management considers aspects of sustainability. The third step was an interview conducting with some kinds of respondents such as expert and local people. The fourth step was data formulation and elaboration becoming the result of this study.

\subsection{Formulation of problems and research objectives}

Based on the grounding conseptual framework and the problems mentioned above, the questions posed in this study are:

(1) Whether the perception and social interaction built by the local community, national park managers, and other stakeholders can provide opportunities for the formation of a collaborative management built on mutual respect and mutual benefit, and whether it can be sustainable?

(2) Whether the local culture established in the local community can be a foundation for the formation of a collaborative pattern among stakeholders and can strengthen the bargaining position of local communities on the created collaborative management and, furthermore, if it can be relied upon to preserve and protect the biodiversity of Kerinci Seblat National Park?

(3) How to linkage implementation of co-management towards politically and economically development of Kerinci Regency?

(4) Can the potential of ecotourism in and around the protected areas build a collaborative management effort among stakeholders, particularly one that involves local community?

Referring to the above problems, this study aims to:

(1) Analyze the perception and interaction patterns in the utilization of potential in and around the conservation area.

(2) Identify the local culture and determine how it can be used as the basis for the creation of collaborative management.

(3) Identify the rights of local communities in relation to the utilization of the conservation area potential.

(4) Identify and analyze the ecotourism as a potential sector and can be held among stakeholder collaboratively.

(5) Identify the key factors for the implementation of a collaborative management. 


\subsection{The structure of dissertation and reporting style}

The paper is divided into nine chapters:

(1) Chapter 1 covers the research background, research questions and research objectives. In this chapter, insights into how the research explores actors' points-of-view for conducting a collaborative management.

(2) Chapter 2 gives a review of the literature related to forest governance and collaborative management, with respect to national parks and the other sources.

(3) Chapter 3 describes the research methodologies along with the qualitative methods used in the descriptive analysis. Moreover, this chapter explains the primary and secondary data used in the analysis, including information regarding how the data were gathered and analyzed by concept of co-management.

(4) Chapter 4 describes the geography of the case study site: Kerinci Regency and Kerinci Seblat National Park (KSNP). Existing conditions and landscape characteristics of the area, such as ownership changes, are explained in detail.

(5) Chapter 5 focuses on the perception of the local community and their activities in terms of utilization of natural resources in KSNP. This chapter goes into detail about how local communities serving as the main actor can understand, utilize and preserve natural resources. The primary question is related to the perspectives of local communities regarding natural resources, preservation activities, ecotourism potencies which spread out in the regency of Kerinci and KSNP. Additional concerns are perspectives of local communities about knowledge and utilization of forest resources, and livelihood which depend on the existence of forest area. The perceptions of natural resource preservation cover perceptions of local communities to the utilization area, problems with managing KSNP, property rights of area utilization and agrarian history. The perceptions of ecotourism benefits include perceptions of local communities to tourism attractiveness and local culture related to communities' rewards from natural resources. From these interactions, the perspectives of collaboration in terms of natural resources' existence and KSNP from local communities can be analyzed.

(6) Chapter 6 analyzes how local government and the manager of KSNP utilize the natural resources of KSNP to achieve preservation of the protected area in the context of local economy and its politics. This chapter analyzes the main factors as a foundation of perceptions and interactions amongst stakeholders to achieve the preservation of the national park in terms of local economy and politics. 
(7) Chapter 7 reviews forest resources in Indonesia with respect to potential ecotourism in and around the park.

(8) Chapter 8 describes how to develop collaboration patterns (a modelling of collaborative management from the empirical study). Perspectives of natural resource management has a strong relationship with economic and political interests for stakeholders. This chapter analyzes the perspectives of local community, local government and the manager of KSNP related to management of natural resources and the national park.

(9) Chapter 9 concludes with the pattern of collaboration management for stakeholders and also to recommend the appropriate collaboration management and collective efforts for stakeholders. 


\section{Chapter II. Theoritical Approaches and Conceptual Framework}

This chapter explains the theoretical approaches related to the management and utilization of the conservation area. According to grounding conceptual framework to carry out this study in detail the theoretical framework that is used is described in this chapter, while the overall design of the research work is described in Chapter III. To find the tendency of perception and behavior of two main stakeholders, namely local communities and governmental agencies toward the natural resources use around them are then used the approach of common pool resource theory and governance-based theory. In this study, using three conceptual frameworks (participation, process, power sharing) were conducted to figure out the tendency of perception and behavior (Sandström, 2009).

According to discovering the patterns of collaborative management among stakeholders, this study has theoretically used an adaptive co-management approach in aming social learning as main perspective (Schusler, Decker, \& Pfeffer, 2003; Olsson \& Folke,2004; Berkes,2009). It is due to adaptive co-management contributes to two aspects such as common purpose and good relationship (Schusler, Decker, \& Pfeffer, 2003). From these two aspects, this study was then directed to find collective actions in the development of comanagement. In detail, describing about a variety of theoretical perspectives and approaches is in Section 2 of this chapter. At the beginning of the theoretical discussion in this chapter, some perspectives around national parks and protected areas are spelled out. It covers definitions of national parks, management of national parks based on the zonation system, environmental management based on the common resource pool theory and the governance approach, as well as collaborative management.

\subsection{Management and utilization on a conservation area}

\subsubsection{Definition of a national park}

A national park is a form of protected or conservation area (Sugardjito, Boekhorst, \& Hooff, 1987; Shafer, 1999; Linkie, Dinata, Nofrianto, \& Leader-Williams, 2007; Juutinen, et al., 2011; Supriatna, 2013; Alikodra, 2013; Dudley, 2013). National parks or conservation areas are one of the most popular tourist destinations in some countries including in Indonesia (Eagles, McCool, \& Haynes, 2002; Akama \& Kieti, 2003; Beunen, Regnerus, \& Jaarsma, 2008). National parks dedicated to the protection of biodiversity and tourism must be managed appropriately, thus, reducing biodiversity shrinkage is a welfare reducing managerial action taken in national parks (Juutinen, et al., 2011; Dudley, 2013). A protected 
area like conservation area is an area of land and/or sea which is especially dedicated to the protection and maintenance of biological diversity, as well as of natural and associated cultural resources, and is managed through legal or other effective means (Myers, Mittermeier, Mittermeier, Fonseca, \& Kent, 2000; Bruner, Gullison, Rice, \& Fonseca, 2001; Ferraro \& Kiss, 2002; Rodrugues, et al., 2004; Naughton-Treves, Holland, \& Brandon, 2005; Chape, Harrison, Spalding, \& Lysenko, 2005). There are six groups of protected areas including conservation area: 1) strict protection such as strict nature reserve and wilderness area, 2) ecosystem conservation and protection such as national parks, 3) conservation of natural features such as natural monuments, 4) conservation through active management such as habitat/species management areas, 5) landscape/seascape conservation and recreation, for example, protected landscapes/seascapes, and 6) sustainable use of natural resources, for instance, managed resource and protected areas (Dudley, 2013).

A national park is a natural area of land and/or sea designated to: (a) protect natural biodiversity along with its underlying ecological structure and supporting environmental processes, and to promote education and recreation (primary objective); (b) manage the area in order to perpetuate, in as natural a state as possible, representative examples of physiographic regions, biotic communities, genetic resources and unimpaired natural processes; (c) maintain viable and ecologically functional populations and assemblages of native species at densities sufficient to conserve ecosystem integrity and resilience in the long term; (d) contribute in particular to conservation of wide-ranging species, regional ecological processes and migration routes; (e) manage visitor use for inspirational, educational, cultural and recreational purposes at a level which will not cause significant biological or ecological degradation to the natural resources; (f) take into account the needs of indigenous people and local communities, including subsistence resource use, in so far as these will not adversely affect the primary management objective; $(\mathrm{g})$ contribute to local economies through tourism (Dudley, 2008). A national park should be managed to ensure preservation (Schwartzman, Moreira, \& Nepstad, 2000; Hayes, 2006; Ezebilo \& Mattsson, 2010; Vodouhê, Coulibaly, Adégbidi, \& Sinsin, 2010; Chowdhury \& Koike, 2010; Cantú-Salazar \& Gaston, 2010). The objectives of national park management are:

1) Protecting natural and scenic areas of national and international significance for the purposes of spiritual, scientific, educational and recreational benefit.

2) Preserving as natural a state as possible, representation of physiographic regions, biotic communities, genetic resources and species, as well as providing diversity and ecological stability. 
3) Managing visitor use for recreational, cultural, educational and inspirational intentions at a level which will preserve the area naturally or authentically.

4) Eliminating and preventing exploitation or occupation that is contrary to the national park's designation.

5) Maintaining respect to the attributes of ecology, geomorphology, sacred or aesthetic features which warranted designation.

6) Taking into account the needs of indigenous and local people, including subsistence resource use in a way that these people will not adversely affect the primary management objectives.

The Law of Indonesia Number 5 of 1990 regarding the conservation of natural resources and ecosystems defines a national park as a nature conservation area which has an original ecosystem, is managed by a zoning system and is utilized for research, science, education, cultivation support, tourism, and recreation (The World Bank, 2006; Mulyana, et al., 2010; Purwandana, et al., 2014; Weeks, et al., 2014). Governmental Regulation No. 28 of 2011 on the management of natural reserve areas and natural conservation areas elaborates on the criteria for an area being designated as a national park, this elaboration is as follows:

1) It has unique natural resources and an ecosystem that is still intact and has natural phenomenon.

2) It has one or several ecosystems which are still intact.

3) It has a sufficient area to ensure continuity of natural ecological processes.

4) It represent of the area is classified into core zone, utilization zone, wilderness zone, and/or other zones due to the needs.

A national park is also a forest park and a natural tourism park which has fungction of a life support protection, preservation of plant and animal diversity, as well as sustainable use of natural resources and ecosystems (Nugraha \& Sugardjito, 2009). Utilization of a national park can be according to the following activities:

1) Scientific research and development

2) Education and increased awareness of nature conservation

3) Storage and/or sequestration of carbon, water utilization, heat and wind energy, and natural objective.

4) Utilization of wild plants and animals

5) Utilization of biodiversity resources for supporting cultivation

6) Traditional use activities of non-timber forests including harvesting, traditional cultivation, as well as traditional hunting is limited to species that are not protected. 
MacKinnon et al. (1993) defined a national park as a natural conservation area, along with being large relatively undisturbed areas of magnificent natural value with high conservation importance, high recreation capabilities, easily accessible for travelers, and has clear benefits for the surrounding region. Furthermore, there are several basic aspects of an area that is designated as a national park, namely: (a) characteristics of unique ecosystems; (b) species diversity or value-specific species (c) landscape with geophysical characteristics or value aesthetic (d) protective function for hydrology (soil, water, local climate); (e) facilities for outdoor recreation or tourist activity; (f) significant cultural heritage (temples, ancient relics, etc.). According to Badman \& Bomhard (2008), a national park is a protected area managed mainly for ecosystem protection and recreation - natural area of land and/or sea designated to (a) protect the ecological integrity of one or more ecosystems for present and future generations, (b) exclude exploitation or occupation inimical to the purposes of designation of the area and (c) provide a foundation for spiritual, scientific, educational, recreational and visitor opportunities, all of which must be environmentally and culturally compatible.

A national park is a form of a conservation area with the defined goal of maintaining biodiversity, although the challenges met by some Developed/Temperate/Western countries are different from some Developing/Tropical/Southeast Asian countries (Shafer, 1999; Juutinen, et al., 2011). National parks have advantages such as being an extensive natural conservation area, relatively undisturbed, natural values with high conservation interest, as well as increasingly attracting visitors to experience pristine and unique natural environments (Orams, 2002; Reinius \& Fredman, 2007). The increased number of visitors to national parks have provided business opportunities both in the parks, as well as in adjacent communities (Stone, 2002). There are several economic, social and ecological aspects that need to be monitored in order to sustain high quality visitor experiences (Fortin \& Gagnon, 1999; Reinius \& Fredman, 2007). Through its management, a national park applies the principles of protecting and preserving by wisely utilizing and minimizing inflicted damage (Alikodra, 2013).

There are 50 conservation areas in Indonesia which are designated as national parks. This number will continue to grow through the promotion of several conservation areas into national parks, as was the case with Wakatobi Marine National Park, Mount Ciremai National Park, Raja Ampat National Park, and Mekongga National Park in 2013 (Alikodra, 2013). Article 1, Paragraph 1 of the Indonesian Government Regulation on Natural Reserve and Conservation Areas describes the criteria for an area to be designated as a conservation area are as follows: 
1) It has a sufficient area to ensure the continuity of natural ecological processes

2) It has specific and unique natural resources, as well as unique plants, animals, ecosystems, and natural phenomena that are still intact

3) It has one or several intact ecosystems

4) It has the original and natural site of the nature to be developed as a natural tourism

5) The area that can be divided into the core zone, utilization zone, wilderness zone and other zones according to the specific benefits of area rehabilitation, dependency of residents around the area and, in order to support efforts to conserve natural resources and ecosystems, a separate zone.

In Indonesia, a national park is established to protect native ecosystems, which are further managed by the national park authority (Geographic, 2011). The area is categorized based on a zoning system to facilitate proper management for research, science, education, aquaculture, tourism and recreation purposes (Law No. 5 of 1990; Mulyana, et al., 2010; Rotich, 2012).

\subsubsection{Zoning system as a management pattern of national park}

The area within a national park is divided by a zoning system in order to ensure proper management efforts (Brax, 2002; Leverington, Costa, Pavese, Lisle, \& Hockings, 2010; Mulyana, et al., 2010; Rotich, 2012; Getzner, Jungmeier, \& Pfleger, 2012). One of the objectives of a zoning system is to minimize potential conflict between the actors within a national park (Adiprasetyo, 2010; Mulyana, et al., 2010; Blouch, 2010). According to Protected Area Mandates, other objectives of zoninng system of national parks are to conserve biological diversity, to improve human wellbeing, to provide economic benefits with multiple scales, to mitigate conflict, and to preserve indigenous cultures (Rotich, 2012). Some uses of zoning are to clarify the area that who could be used and who is not, to distinguish the functions of the areas of the region, to help reducing conflicts from different users, in order to maintain the ecological value, to recover area and to limit the number of the revelation in the context of tourism. Regarding to the Regulation of the Minister of Forestry of the Republic of Indonesia Number P.56 / 2006, national park management can be divided into seven regions based on the functions of conservation zones and utilization purposes. The seven zones of the region and their designations (Article 6 the Minister of Forest of Indonesia, Number. P.56/Menhut-II/2006) are as follows:

1) The core zone for protection of ecosystems, along with the preservation of flora and fauna and its habitat are sensitive to disturbances and changes, serve as a source of 
germplasm of wild plants and animals, is an area for science research and development, education and supporting cultivation.

2) Wilderness zone for preservation activities and the utilization of natural resources and the environment for research, conservation education, limited tourism, wildlife habitat and supporting migrants, as well as cultivation and the core zone.

3) Zone for nature tourism and recreation development, environmental services, education, research and development that supports utilization and cultivation activities.

4) Traditional zone for utilization of given potencies of national parks by local communities in a sustainable way, while still meeting their needs.

5) Rehabilitation zone to restore ecosystems' damaged areas to or close to its natural condition.

6) Zone of religion, culture and history to show and protect the values of work, culture, history, archeology and religion such as a research media; education and nature of history, archeology and religious.

7) Specific zone for group activities of local people living in the region before this area was designated as a national park. The zone supports their livelihood and helps to build infrastructures such as telecommunication facilities, transport facilities, and electricity.

Zoning system management is used as a reference for national park management when implementing zone arrangements in national parks, as well as serving as a means of effectively managing national parks (Brax, 2002; Rotich, 2012). The three major zones in the national park area are the core zone, wilderness zone and utilization zone. The other zones may be added depending on the region, its conditions and socio-economic and cultural communities living around the national park. These optional zones include traditional zone, rehabilitation zone, religion zone, culture and history zone, and a special zone. In the core zone, everyone is prohibited from doing activities that can lead to changes within the national park. Changes in core zones include reducing or eliminating the functions, as well as adding plants and animals that are not currently in the area. The core zone is a part of national park that has good natural conditions or physically pristine biota; the zone is also used to protect original and unique biodiversity representation (Act No. 5 of 1990, the Minister of Forestry Regulation No. 56 In 2006, the Government Regulation 28 of 2011).

A wilderness zone is a zone that is capable of supporting preservation in the core and utilization zones based on its location, condition and effectiveness. A wilderness zone includes the habitat area that is to be protected and is intended to support the breeding behaviors of wild animals. A utilization zone is mainly used for the benefit of nature tourism and conditions/other environmental services. The utilization zone has the following criteria: 
(a) naturally attractive in the form of plants, animals or ecosystems, or be in the form of certain formations and beautiful and unique geological formations; (b) has an area sufficient for ensuring sustainability and attractiveness that may potentially be used for tourism and outdoor recreation; (c) environmental conditions that favor the use of environmental services, development of nature tourism, research and education; (d) an area that allows the construction of infrastructure for the utilization of environmental services, natural tourism, recreation, research and education; (e) it is not directly adjacent to the core zone (Indonesian Government, No. 28 of 2011). Rotich (2012) have divide zone of national park into some types of groups. Tables 2, 3, 4 explain and describe the types of zoning system of protected area.

Table 2 Zones of influence, outside the protected area

\begin{tabular}{|c|c|c|}
\hline $\begin{array}{l}\text { National } \\
\text { Administrative } \\
\text { Zones }\end{array}$ & $\begin{array}{l}\text { To maintain conservation and } \\
\text { environmental protection on a } \\
\text { regional scale and to promote } \\
\text { regional and national } \\
\text { cooperation and coordination } \\
\text { on conservation }\end{array}$ & $\begin{array}{l}\text { To cordinate management efforts } \\
\text { with regional and national land use } \\
\text { and planning agencies }\end{array}$ \\
\hline $\begin{array}{l}\text { International } \\
\text { Administrative } \\
\text { Zones }\end{array}$ & $\begin{array}{l}\text { To maintain conservation and } \\
\text { environmental protection on } \\
\text { an international scale \& to } \\
\text { promote international } \\
\text { cooperation and coordination } \\
\text { on conservation }\end{array}$ & $\begin{array}{l}\text { To collaborate with and to contribute } \\
\text { to international conventions, } \\
\text { agreements and organizations (e.g. } \\
\text { IUCN, UNESCO, CBD, Ramsar) }\end{array}$ \\
\hline Awareness zone & $\begin{array}{l}\text { No defined boundary \& To } \\
\text { raise awareness of and } \\
\text { support for conservation and } \\
\text { the protected area }\end{array}$ & $\begin{array}{l}\text { To promote, to advertise, park } \\
\text { outreach programmes, park web site }\end{array}$ \\
\hline
\end{tabular}

Source: Rotich, 2012 
Table 3 Kinds of management zone defined within the protected area and wider zones

\begin{tabular}{|c|c|c|}
\hline $\begin{array}{l}\text { Zone (May be } \\
\text { legally defined or } \\
\text { not }\end{array}$ & $\begin{array}{l}\text { Management Objectives and } \\
\text { Priorities }\end{array}$ & Management Approach \\
\hline $\begin{array}{l}\text { Core } \\
\text { Conservation } \\
\text { Zone }\end{array}$ & $\begin{array}{l}\text { (a)Total priority for } \\
\text { conservation of species, } \\
\text { habitats, ecosystems, } \\
\text { landforms and landscapes; } \\
\text { (b) Normally allowing only } \\
\text { limited, nondestructive, } \\
\text { management oriented } \\
\text { monitoring, and research }\end{array}$ & $\begin{array}{l}\text { (a) Total protection through patrol, } \\
\text { enforcement and monitoring; (b) } \\
\text { Absence of any facilities that would } \\
\text { assist access or use }\end{array}$ \\
\hline $\begin{array}{l}\text { Wilderness } \\
\text { zone/Non } \\
\text { intervention zone }\end{array}$ & $\begin{array}{l}\text { (a) for } \\
\text { conservation, maintenance } \\
\text { of natural landscape values } \\
\text { and quiet enjoyment of } \\
\text { nature and natural areas; (b) } \\
\text { Normally allows natural } \\
\text { processes to occur with } \\
\text { minimal management } \\
\text { intervention and without } \\
\text { infrastructure development; } \\
\text { (c) Normally allowing } \\
\text { survey, research and } \\
\text { monitoring and regulated } \\
\text { low level, low impact } \\
\text { recreation with few } \\
\text { facilities. }\end{array}$ & $\begin{array}{l}\text { (a) Protection through patrol and } \\
\text { enforcement of strictly defined use } \\
\text { regulations; (b)Provision of basic off } \\
\text { site Information and interpretation; (c) } \\
\text { Facilities to assist access and use, but } \\
\text { no permanent and artificial structures }\end{array}$ \\
\hline $\begin{array}{l}\text { Intensive } \\
\text { Zone }\end{array}$ & $\begin{array}{l}\text { (a) Accessible and ideally } \\
\text { less vulnerable areas } \\
\text { enabling large numbers of } \\
\text { visitors to use and enjoy the } \\
\text { area within acceptable } \\
\text { limits; } \quad \text { (b) Offering }\end{array}$ & $\begin{array}{l}\text { (a) Provision of extensive on-site } \\
\text { information and interpretation; } \\
\text { (b)Provision of high quality facilities } \\
\text { and infrastructure for visitors and other } \\
\text { users; (c) Use and enforcement of } \\
\text { defined regulations for users, }\end{array}$ \\
\hline
\end{tabular}




\begin{tabular}{|c|c|c|}
\hline & $\begin{array}{l}\text { organized recreation with } \\
\text { appropriate } \\
\text { amenities, interpretation and } \\
\text { education facilities and } \\
\text { regulated } \\
\text { activity; } \\
\text { management infrastructure } \\
\text { is also often located in this } \\
\text { zone }\end{array}$ & Acceptance of moderate user impact \\
\hline $\begin{array}{l}\text { Intensive } \\
\text { Enclaves } \\
\text { Corridors }\end{array}$ & $\begin{array}{l}\text { (a) Enabling large numbers } \\
\text { of visitors to visit specific } \\
\text { locations inside the PA } \\
\text { which may be inside } \\
\text { restricted zones (normally } \\
\text { religious or cultural sites); } \\
\text { (b) Organized and regulated } \\
\text { visiting often allowed at } \\
\text { specific and significant } \\
\text { times of year (religious and } \\
\text { cultural festivals) }\end{array}$ & \\
\hline $\begin{array}{l}\text { Development } \\
\text { Enclaves or } \\
\text { Corridors }\end{array}$ & $\begin{array}{l}\text { (a) Enabling continued } \\
\text { function of established } \\
\text { developments inside more } \\
\text { restricted zones. Examples } \\
\text { include hydroelectric } \\
\text { installation, major roads; (b) } \\
\text { According to agreement } \\
\text { with users and their existing } \\
\text { use rights }\end{array}$ & $\begin{array}{l}\text { (a) Close liaison with site managers in } \\
\text { enclaves; (b) Very clearly defined } \\
\text { boundaries and limits of use; (c) } \\
\text { Regular monitoring }\end{array}$ \\
\hline
\end{tabular}

Source: Rotich, 2012 
Table 4 Management zones that may be either inside or outside the protected area

\begin{tabular}{|c|c|c|}
\hline Buffer zone & $\begin{array}{l}\text { (a) it is aimed at the } \\
\text { integration of research, } \\
\text { education, tourism, } \\
\text { sustainable use and } \\
\text { development and traditional } \\
\text { activities; (b) to promote and } \\
\text { to assist non-destructive, } \\
\text { sustainable activities that will } \\
\text { not harm the protected area; } \\
\text { (c) to allow limited } \\
\text { commercial and settlement } \\
\text { development based on } \\
\text { defined environmental and } \\
\text { design guidelines }\end{array}$ & $\begin{array}{l}\text { (a) to collaborate with other land } \\
\text { management agencies and local } \\
\text { resource users; (b) Incentives and } \\
\text { development extension assistance } \\
\text { and advice for local inhabitants } \\
\text { Interpretation, awareness and } \\
\text { education for local inhabitants and } \\
\text { visitors }\end{array}$ \\
\hline $\begin{array}{l}\text { Transition/sustainable } \\
\text { development zone } \\
\text { (areas adjacent to the } \\
\text { managed area) }\end{array}$ & $\begin{array}{l}\text { (a) Not always fully defined } \\
\text { area surrounding the park; (b) } \\
\text { Emphasis on encouraging } \\
\text { sustainabler and } \\
\text { environmentally friendly } \\
\text { development activities, which } \\
\text { create links between park and } \\
\text { its surrounding area. }\end{array}$ & $\begin{array}{l}\text { (a) Incentives, collaborations, } \\
\text { partnerships, planning guidelines. } \\
\text { Indirect protection and monitoring } \\
\& \text { Awareness and education; (b) } \\
\text { Incentives and information } \\
\text { Collaboration/consultation with } \\
\text { land management agencies. }\end{array}$ \\
\hline Ecological Zones & $\begin{array}{l}\text { (a) Protecting ranges of } \\
\text { species, habitats and } \\
\text { ecosystems that spread } \\
\text { beyond the park boundary, } \\
\text { (b) Encouraging maintenance } \\
\text { of landscape links; avoiding } \\
\text { fragmentation; maintaining } \\
\text { source populations outside } \\
\text { the PA; preventing flows of } \\
\text { pollutants into the PA }\end{array}$ & $\begin{array}{l}\text { (a) Collaboration/consultation with } \\
\text { land management agencies, local } \\
\text { authorities, local communities and } \\
\text { other stakeholders, international } \\
\text { agencies and other countries; (b) } \\
\text { Contributing to local and regional } \\
\text { land use plans }\end{array}$ \\
\hline
\end{tabular}




\begin{tabular}{|l|l|l|l|}
\hline Cultural Zones & $\begin{array}{l}\text { (a) Protecting cultures and } \\
\text { sustainable } r \text { traditional }\end{array}$ & $\begin{array}{l}\text { (a) Consulting with different } \\
\text { cultural and community groups }\end{array}$ \\
practices of peoples whose & and their leaders \\
territory includes the PA. (for & \\
example nomadic or seasonal & \\
grazer's); (b) Encouraging \\
maintenance of traditional \\
practices that support PA \\
objectives
\end{tabular}

Source: Rotich, 2012

Mulyana et al. (2010) has proposed a simplification of the zone system to a national park in Indonesia from seven zones according to the 2006 regulation into two zones, namely the use zone (special zone) and conservation zone (core area). Special zone is intended as a result of an agreement between the various parties managed collaboratively. The general principles that apply to all national parks in Indonesia are (1) the special use zone is an integral part of the national park, with clear boundaries agreed by all stakeholders and with direct geographical, social, economic, and cultural links to the area outside the park; (2) land and resources within the special use zone remain state land with a conservation function; (3) people may receive rights of use, management or access, but no rights of ownership; (4) specific rules on who has rights, what rights are given and the responsibilities linked to those rights need to be developed and agreed by the stakeholders; (5) all use must be environmentally friendly, based on principles of conservation and sustainability; (6) local rules developed for the special use zones are binding on all people receiving rights to the special use zone; (7) the park agency should exercise its authority in a responsible and accountable manner, collaborating with and respecting other parties is. Thus, the purposes of establishing a special zone are (1) remains biodiversity conservation (the primary purpose of a special use area) and (2) sustainable use to enable local users, stakeholders, to maintain or achieve a desirable level of wellbeing, to make park management easier and provide a buffer zone for the core zone (secondary purpose). At the end of the special zone will be a way out of the conflict with the following assumptions;

(1) The Directorate General of Forest Protection and Nature Conservation is committed to strengthening law enforcement after the special use zone is established to create order and clarity on what is allowed and what is not. This is to be supported by regular monitoring. 
(2) All stakeholders are willing and able to cooperate and collaborate, regulated through a Memorandum of Understanding clearly stating respective rights, duties and responsibilities.

(3) Law enforcement by the Ministry of Forestry is supported by other government agencies.

(4) Local governments and local people are willing to adopt the concept and take on management of special use zones.

(5) The government does not over regulate the process for establishing special use zones but allow opportunities to develop a special use zone in accordance with local needs and conditions.

There are many conceptual frameworks and empirical case studies related to natural resource management specifically with regards to developing collaborative management. These conceptual frameworks can be grouped into two approaches: 1) The common pool pesource (CPR) theory which originally came from rational choice institutionalism, 2) Governance theory initially coming from sociological institutionalism. These two groups have built the neo institutionalism theory in which collaborative management is implemented into the boarbness of the new institutional framework. Institutions define a set of rules or decisionmaking procedures for managing interactions between actors, as well as serving as a basis for political behavior (Sandström, 2009).

\subsection{Environmental governance}

Environmental management has played a crucial role in the context of sustainable development. Environmental management has also give an effect to the individual, society, farmers, governments, government agencies, and also NGOs both local level and international level. Barrow (2006) have summarized some of the definitions of environmental governance shown in Table 5 below.

\section{Table 5 Definition of environmental governance}

\begin{tabular}{|l|l|}
\hline \multicolumn{1}{|c|}{ Definition } & \multicolumn{1}{|c|}{ Sources } \\
\hline An approach which goes beyond natural resources & R. Clarke, Birkbeck College, \\
management to encompass the political and social as & University of London: personal \\
well as the natural environment. It is concerned with & communication \\
questions of value and distribution, with the nature of \\
regulatory mechanisms and with interpersonal, \\
geographic and intergenerational equity
\end{tabular}




\begin{tabular}{|c|c|}
\hline $\begin{array}{l}\text { Formulation of environmentally sound development } \\
\text { strategies }\end{array}$ & \\
\hline $\begin{array}{l}\text { An interface between scientific endeavour and policy } \\
\text { development and implementation }\end{array}$ & $\begin{array}{l}\text { S. Macgill, Leeds University, UK: } \\
\text { personal communication }\end{array}$ \\
\hline $\begin{array}{l}\text { The process of allocating natural and artificial } \\
\text { resources so as to make optimum use of the } \\
\text { environment in satisfying basic human needs at the } \\
\text { minimum, and more if possible, on a sustainable basis }\end{array}$ & Jolly, 1978 \\
\hline $\begin{array}{l}\text { Seeking the best possible environmental option to } \\
\text { promote sustainable development }\end{array}$ & $\begin{array}{l}\text { paraphrased from several 1990s } \\
\text { sustainable development sources }\end{array}$ \\
\hline $\begin{array}{l}\text { Seeking the best possible environmental option } \\
\text { (BPEO), generally using the best available techniques } \\
\text { not entailing excessive cost (BATNEEC) }\end{array}$ & $\begin{array}{l}\text { two widely } \\
\text { used environmental management } \\
\text { acronyms }\end{array}$ \\
\hline $\begin{array}{l}\text { The control of all human activities which have a } \\
\text { significant impact upon the environment. }\end{array}$ & \\
\hline $\begin{array}{l}\text { Management of the environmental performance of } \\
\text { organisations, bodies and companies }\end{array}$ & Sharratt, 1995 \\
\hline $\begin{array}{l}\text { A decision-making process which regulates the impact } \\
\text { of human activities on the environment in such a } \\
\text { manner that the capacity of the environment to sustain } \\
\text { human development will not be impaired }\end{array}$ & $\begin{array}{l}\text { paraphrase from various 1990s } \\
\text { 'green development' sources }\end{array}$ \\
\hline $\begin{array}{l}\text { Environmental management cannot hope to master all } \\
\text { of the issues and environmental components it has to } \\
\text { deal with. Rather, the environmental manager's job is } \\
\text { to study and try to control processes in order to reach } \\
\text { particular objectives }\end{array}$ & Royston, 1978 \\
\hline $\begin{array}{l}\text { Environmental management - a generic description of } \\
\text { a process undertaken by systems-oriented } \\
\text { professionals with a natural science, social science, or, } \\
\text { less commonly, an engineering, law or design } \\
\text { background, tackling problems of the humanaltered } \\
\text { environment on an interdisciplinary basis from a } \\
\text { quantitative and/or futuristic viewpoint }\end{array}$ & Dorney, 1989: 15 \\
\hline
\end{tabular}


Environmental management has integrated several aspects such as ecology, policy making, planning and social development, and whatever else is needed in aiming to; (a) sustaining and, if possible, improving existing resources; (b) the prevention and resolution of environmental problems; (c) establishing limits; (d) founding and nurturing institutions that effectively support environmental research, monitoring and management; (e) warning of threats and identifying opportunities; (f) where possible improving 'quality of life'; (g) identifying new technology or policies that are useful (Barrow, 2006). Lemos \& Agrawal (2006) emphasized two aspects on environmental management such as consequential environmental problems, global climate change and ecosystem degradation. Therefore, definition of environmental governance has been addressed to four domain of scholarships namely globalization, decentralization, market and individual incentives-based governance, and cross-scale governance.

A number of the conceptual frameworks related to natural resource management have been developed and defined in an effort to conduct studies on collaboration management including developing collaborative management in Indonesia (Feyerabend, 1996; Clifton, 2003; Carlsson \& Berkes, 2005; Berkes, 2009; Conley \& Moote, 2010; Indrawan, Lowe, Sundjaya, Hutabarat, \& Black, 2013; Gurney, et al., 2014). These conceptual frameworks have been grouped into two main approaches, the group common pool resource (CPR) theory, which originally comes from rational choice institutionalism (Olson, 1965; North, 1990; Agrawal, 2003) and the governance theory which originally stems from sociological institutionalism (Olsson, Folke, Berkes, 2004; Carlsson \& Berkes, 2005; Sabatier, Leach, Lubbel, \& Pelkey, 2005; Miller \& Banaszak-Holl, 2005; Sandström, 2009). Two groups of these theories together is in the range of neo institusionalism theory in which its research and analysis of the preparation of the collaborative management carried into the new institutional framework. Institutions that will define a set of rules or decision-making procedures and programs that are demanding interaction between actors and also the cornerstone of all political behavior (Sandström, 2009).

\subsubsection{Concept of common-pool resource approach}

Common Pool Resource (CPR), also referred to as the common property resource or the rational approach, illustrates the elements of neo-classical economic theory which initially emerged from American congressional behavior (Hall \& Taylor, 1996). The theory explains the form of interactions amongst decision making actors. The assumption is that the actors have maximal benefits and that they are able to rank their priorities in accordance with 
exogenous preferences. Therefore, some research about natural resouces focused on formal rules and actors affecting collaborative management. In this approach, institutions provide a set of formal rules and procedures or informal activities related to management structures. It is commonly called a strategic environment (Sandström, 2009).

There are four main features of rational choice institutionalisms. First, this approach uses characteristics of behavioral assumptions, specifically that suitable actors have determined tastes or preferences. Actors do a study in strategic ways based on extensive calculations. Second, the approach has a distinctive image of politics, which views politics as a series of collective action dilemmas. Moreover, this means that when individuals prefer to maximize their own preferences are likely to produce an outcome that is collectively suboptimal. Other outcome could be achieved that would make at least one of the actors better off without making any of the others worse off. The third indicates the role of strategic interactions in the determination of political outcomes. This feature provides the largest contribution to the rational approach. Moreover, this feature has two postulates: (1) an actor's behavior is apparently driven by a strategic estimation, and (2) this estimation will be strongly influenced by the actor's expectations about how others are likely to behave. The rational choice theory uses a classic "'calculus approach" to explain how institutions affect individual activities. The final feature of the rational approach is a distinctive method to explaining the problem of how institutions are established. With this, the institution's existence refers to the value of those functions have for the actors affected by the institutional perspective. The assumption is that the actors establish an institution to achieve a value which is most often conceptualized in terms of cooperation gains (Hall \& Taylor, 1996).

Rationality on joint action in an attempt to achieve common goals is also known as 'group theory' and was originally introduced by Olson (1965). This idea refers to the concept that an individual group with common interests will act on behalf of the group's common interests (theory of group). Group theory often leads to the development of an organization which further acts to achieve the common interest of all individuals in the group. Olson (1965) provided several examples of organization types which promote the interests of their members; for example, labor unions, farm organizations, cartels, cooperatives, and a state. A labor union is expected to strive for higher wages and better working conditions. A farm organization is expected to strive for favorable legislation. Cartels are expected to strive for higher prices of participating firms. Cooperatives are expected to further the interests of its stockholders. A state is expected to further the common interests of its citizens. In an organization, there are both individual and common interests. For example, members of a 
labor union have the common interest of higher wages, and the citizens' common interest in good government.

Olson (1971) described a combination of individual and common interests in an organization as being similar to a competitive market. He explained that companies in a competitive industry would have the common interest of obtaining a higher price. Therefore, an individual company cannot sell products at higher prices because all companies have the same price. Furthermore, a company sells as many products as possible to cover per unit production costs, meaning that all companies selling the same product have a common interest, but they have opposite interests associated with each output.

\subsubsection{Concept of sociological institutionalism}

The concept of sociological institutionalism is a new variety of institutionalism in the realm of political science. This approach was deployed to aid in the debate related to differences between modern and traditional organization theory, especially concerning a cultural series. The concept of sociological institutionalism assumes that many of the institutional forms and procedures used by modern organizations were not adopted simply because they were the most efficient for the tasks at hand. However, shapes, forms, and procedures should be seen as culturally specific practices, akin to the myths and ceremonies devised by many societies, and then be assimilated into organizations, doing so is not necessarily an effort to enhance reviews of their formal means-ends efficiency, but as a result of the kind of processes associated with the transmission of cultural practices. This approach attempts to explain why organizations take on specific sets of institutional forms, procedures or symbols; furthermore, it emphasizes how such practices are diffused through organizational fields or across nations (Hall \& Taylor, 1996).

Sociological institutionalism has three characteristics which are relatively different from the other new institutionalism approaches. First, this concept covers a much broader perspective than just political science. It covers not only formal norms and procedures, but also symbolic systems, cognitive scripts and moral templates that provide the "frames of meaning"' which guide human action, with some definitions being divided into categories of "'institutions"' and "culture'. Second, the concept provides a distinctive understanding of the relationship between institutions and individual action, which follows the "cultural approach" but displays some characteristics of the institutional approach and further emphasizes cognitive dimension. Institutions influence behavior by providing the cognitive scripts, categories and models that are indispensable for action, because without these the world and the behavior of others could not be interpreted. Finally, the concept explains how 
institutional practices originate and change. An example of this is how rational institutionalism explains the development of an institution by reference to the efficiency with which it serves the material ends of those who accept it. By contrast, sociological institutionalism argues that organizations often adopt a new institutional practice, it is not due to advances the means-ends efficiency of the organization, but it enhances the social legitimacy of the organization or its participants (Hall \& Taylor, 1996).

\subsection{Collaborative management}

\subsubsection{Definition and background of co-management}

Collaborative management, or co-management, was initially established in the $1980 \mathrm{~s}$ and is based on the concept of how to synergize conservation and development to achieve sustainable utilization of natural resources (IUCN, 1996 ; Borrini-Feyerabend, Kothari, \& Oviedo, 2004). Through the publication entitled "Caring for the Earth", The World Conservation Union/the International Union for Conservation of Nature and Natural Resources (IUCN), the United Nations Environment Programme (UNEP) and the Worldwide Fund for Nature (WWF) proposed an initial strategy for the sustainability of natural resource areas in 1991. This strategy contains at least two important aspects, namely: (1) creating a link between conservation and development activities, and (2) recognizing the importance of involving the local community in a forest area because the area is a source for their livelihood.

Throughout the last few decades, several definitions of collaborative management have emerged. Borrini-Feyerabend, et al. (2004) defined collaborative management as an action to respond to the presence of two or more actors, which mutually negotiate and mutually determine, as well as mutually guarantee to manage and behave responsibly, along with equitably obtaining the rights to an area and its resources. Pomeroy, McConney, \& Mahon (2004) defined collaborative management as having an emphasis on management authority and responsibility for managing resources that have been agreed upon by the government, local communities and other stakeholders.

Berkes (2009) defined collaborative management as a power sharing and mutual responsibilities between two parties, government and local citizens. Pomeroy and Berkes (1997) defined collaboration management as a control mechanism, with the division of responsibility and authority between government, local communities and related stakeholders that are all involved in managing environmental resources. Furthermore, government and local communities can control one another in case of irregularities. In line with this definition, 
Pinkerton (1994) has defined that collaboration as a power sharing for the utilization of natural resources between government and local community organizations. Therefore, collaborative management is a power sharing allocation of responsibilities, rights, and obligations among key stakeholders, specifically government and local communities. This is further concentrated on the use of natural resources and typically considers the strength combinations of each stakeholder in an attempt to minimize the weaknesses of each (Singleton, 2000; The World Bank, 2003).

Moreover, there is no single uniform definition for collaborative management, although some researchers have tried to establish a consistent and thorough understanding (Grover and Krantzberg, 2010). Increased awareness and distribution among stakeholders in managing natural resources in the form of partnerships is viewed as a suitable collaborative effort among stakeholders. Several other terms have also been interchangeably related to collaborative management, specifically participatory management, joint management, roundtable management, multi-stakeholder management, and shared management. In principle, these terms show the strategies necessary to achieve sustainable natural resource management synergized with conservation and development, as well as the important role of communities in preserving natural resources as an area for their subsistence (Mappatoba, 2004).

The primary differences in the definition of co-management and various approaches of natural resources management, such as community-based resource management (CBRM), are generally related to the allocation of responsibility for the management of natural resources, with responsibility typically being allocated to the government and other user groups. Government and other user groups are the actors involved in the decision making process of natural resource management. Sen and Nielsen (1996) explained the differences between comanagement and community-based resource management, especially for the management of marine resources. In this instance of CBRM, the government is not involved in the decision making process for the management of the marine resources. Consequently, marine system management is not based on collaboration.

Referring to theoretical and empirical studies, there are five classifications of comanagement arrangements which distinguish the role of government and other stakeholders, this is shown in Figure 3 where the spectrum of co-management arrangements has been adopted from the works of McCay (1993), Berkes (1994) and Sen \& Nielsen (1995). 


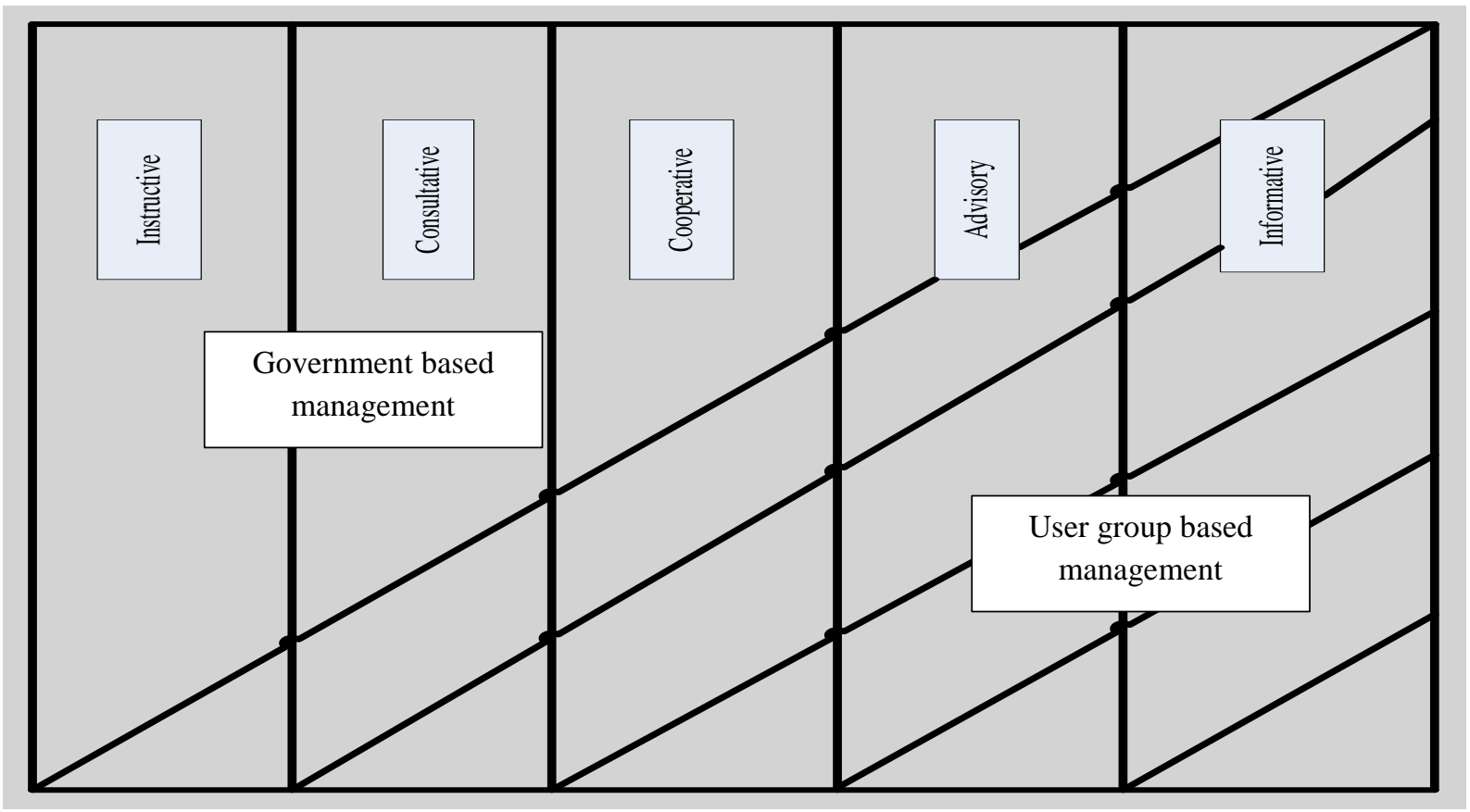

Source: Sen \& Nelsen, 1996

Figure 3 Spectrum of collaborative management

Each type and role of government and users in a collaborative management are as follows:

1) Instructive: there is only minimal exchange of information between government and users. Although there are dialogue mechanisms, the process tends to be that the government makes the decisions and informs the users of the decisions.

2) Consultative: all decisions are created by the government; the government provides consultative mechanisms to the users through institutional structure.

3) Co-operative: government and users equally make most decisions together. Some authors refer to this behavior as being the definition of co-management.

4) Advisory: government is expected to support decisions made and suggested by users.

5) Informative: government delegates users to make decisions. Afterwards, users inform the government about the decisions.

It is now important to decide when co-management should be applied. Sandstrom (2009) developed a conceptual framework for defining and conducting research on collaborative management. Nonetheless, collaborative management is not a single solution to all problems (Carlsson \& Berkes, 2005; Grover \& Krantzberg, 2013). Several conditions must be met for applying co-management (Borrini-Feyerabend, et al., 2004), these conditions are as follows:

1) Conflicts in distribution of common resource

2) Increasing uncertainties and complexities in the ecosystem

3) Questions of natural resource management 
4) Emergence of interest to manage natural resources based on proper management approaches

5) Increasing decentralization and globalization

Co-management is not only the solution for natural resource problems, but it is very useful if local communities are present. Co-management can establish a degree of powersharing without eliminating power relations within the community (Carlson \& Berkes, 2005). Co-management will be beneficial in the following situations:

1) Division of labor. One of the advantages of co-management is its ablility to unify different skill levels and knowledge into a joint work. It also leads to a variety of different capacities and comparative advantages; for example, cooperation between small medium enterprises (SMEs) and large enterprises or traders to sell the SMEs' products in the global market. SMEs have particular set of knowledge and skills, as well as different networks at different levels. These can be thought of as being a unique set of information, technical capacity or specialization characterized by a specific scale.

2) Exchange of resources. Co-management systems do not only consist of a relationship between communities and the state, but also cover a number of couplings among different actors. Interrelationships among actors exist because such systems require various degrees of power and resource dependency. For example, local groups may have specific resource requirements that they can not obtain on their own, such as technology, scientific expertise, and information diversity. The state, however, can provide the locals with such resources.

3) Linking different types and levels of organization. Co-management is a way to coordinate different organization types. Each representative of an organization coordinates all agreed upon activities in a particular area or resource system without being hindered by hierarchical bureaucracy.

4) Reducing transaction costs. Co-management is believed to be a relationship among actors who have various networks. Actors involved in the network do not do the same job; there is therefore a division of jobs due to established actor networks, thus reducing transaction costs.

5) Risk Sharing. Co-management systems are believed to be a network of relationships which have evolved over time. Sharing certain management tasks among actors helps to minimize the likelihood of adverse events that may come from relying on only one actor. This is similar to situations where farmers diversify their crops or intercropping systems to minimize risk. 
6) Conflict resolution mechanisms, power sharing. Co-management systems are collaborations which include the rights and obligations of actors to reduce conflicts, as well as develop a long-term problem-solving mechanism.

\subsubsection{Evolution of collaborative management}

For decades, collaboration management has been the main solution to manage problems related to natural resources. The management of natural resources is interpreted as the sharing of powers and responsibilities between government and local people. Berkes (2009) indicated that collaborative management has evolved both in theory and practice. Additionally, other roles of co-management exist, including knowledge generation, bridging organization, social learning and the emergence of adaptive collaborative management.

Knowledge generation. Ecosystem management can be utilized for an abundance of resources; with respect to aspects of human welfare, however, certain knowledge of socialecological systems by a group or institution are required. The management of socialecological systems also needs access to the social networks of multi-level organizations because ecosystems and human behavior changes over time (Berkes et al., 2003, Hanh et al., 2006, Berkes, 2009). One of the strengths of co-management is that the different degrees of knowledge possessed by the actors is an essential aspect in managing natural resources. Each actor brings his/her knowledge to enrich discussion; for example, local institutions have a good knowledge of problems at the local level, but they do not have enough insight at the regional level. A state, moreover, has a complete understanding of a situation at regional and national levels. Furthermore, the comparative advantage needs to be considered with respect to what knowledge can be combined from various levels to ensure full understanding of a problem (Cash and Mosher, 2000; Eamer, 2006; Reid et al., 2006; Berkes, 2009)

Bridging organization. The role of bridging organizations is to provide a neutral arena to facilitate knowledge and local perspectives. Furthermore, it creates knowledge coproduction, trust building, comprehension, learning, vertical and horizontal collaboration, and conflict resolution. Successful bridging organizations should be supported by effective leadership. Therefore, bridging organizations and leadership are key factors that enable a comanagement system to deal with knowledge gaps, especially if local knowledge is based on a different epistemology and worldview than government science (Acheson, 2003; Folke et al., 2005; Berkes, 2009).

Social learning. Environmental management considers the learning approach as a way to face environment uncertainties. Conventional theories only focus on individual learning, but 
the management of social learning focuses on the learning process operating on an environmental scale. Organizational learning is accepted as a new theory, but it is still debated (Berkes, 2009). There are at least three learning theories (Mezirow, 1996; Keen et al., 2005; Keen \& Mahanty, 2006) that have led to self-organization learning processes (Folke et al., 2005). First, experiential learning which is based on the transfer of experiences, i.e., learning by doing, such as the process of insight creation. Second, transformative learning is a process of reflection which allows changes in individual perception and awareness. Third, social learning is a repetitive reflection process when the experience is shared. These three learning theories have become the main concepts in collaborative management, especially in the social-ecological literature.

Many complex resources need to be governed by various agencies, not only government characterized top-down management, but also those which involve publicprivate-civil society partnerships (Burkard, 2007; Berkes, 2009). Co-management is used to implement natural resource management, specifically in consideration of the cooperation of various institutions which seek to share power and responsibilities. Berkes (2009) indicated that the co-management approach has a weak track record in poverty reduction and the empowerment of marginal people. Berkes (2009) analyzed the concept in the fisheries sector in countries such as Bangladesh, Cambodia, Indonesia and the Philippines. Empirical studies have shown that the concept often leads to strengthened state control, while marginal stakeholders are typically excluded (Berkes, 2009).

Berkes (2009) explained that co-management has an ever increasing number of headings. There are six concepts of collaborative management that have emerged over the past two decades:

\section{1) Co-management as power sharing}

Power sharing involves cooperation between a national government and users with regards to sharing power and responsibilities. Power sharing is one of the necessary criteria in implementing successful co-management. In some cases, however, power sharing can cause collaboration problems. Balancing of shared power can be achieved through the legitimacy of the state and formalized arrangements. Institution, capacity building and knowledge sharing can also support the power sharing balance.

\section{2) Co-management as institution building}

There are two reasons that co-management is believed to be an effective solution for institution building. First, local institutions rarely cooperate with the government and, second, government agencies are seldom ready for cooperation with local agencies. 
Therefore, co-management builds an institution network of the government and local institutions.

\section{3) Co-management as trust and social capital}

Co-management is not only focused on the creation of institutions, but also on building trust between actors. Trust is one of the key success factors in implementing comanagement. Social capital is also a significant aspect in all cases of co-management and is a requirement for collective action and social learning.

\section{4) Co-management as process}

The parties involved in co-management agree, in either a formal or semi-formal way, to share rights and responsibilities. The process covering institution building, development of trust and social capital is not an easy one. Co-management is not an end deal, but it is a process in which the relationships between actors are constantly changing. Process development may be quite a substantial need for a very long time.

\section{5) Co-management as problem solving}

Problem solving can be defined as steps in the decision making process that are necessary to choose upon various alternatives. Adaptive management needs collaborative processes to ensure consensus among parties before feedback-based problem solving can proceed. Therefore, co-management and adaptive management supplement one another. Comanagement allows actors to transfer learned information from one situation to another, in an effort to mitigate problems. In this regard, co-management is task-oriented and focused on the function of arrangement.

\section{6) Co-management as governance}

The basic concept of co-management is to develop a situation which is people and government share management responsibility. Direct involvement of communities in resource management decisions, especially related to their livelihoods, is good governance. Co-management as a method of governance frequently involves various actors being responsible for both public and private actors.

These aspects of co-management can be extended by various approaches, such as comanagement as innovation and co-management as conflict resolution. Two increasingly important aspects are co-management as knowledge generation and co-management as social learning. 


\subsubsection{Concept of adaptive collaborative management}

Adaptive co-management is a combination of adaptive management and collaborative management. Adaptive management in the literature is often applied to ecology, while comanagement is more frequently found in general literature (Berkes, 2009). Adaptive management or adaptive resource management is an approach used to manage the environment associated with uncertainties and complexities, e.g., learning by doing. Comanagement is defined as the sharing of powers and responsibilities between the government and local resource users (Fennel et al., 2008; Berkes, 2009). Adaptive management is '”a process by which institutional arrangements and ecological knowledge are tested and revised in a dynamic, ongoing, self-organized process of learning by doing', (Folke et al., 2002).

Adaptive co-management is a process characterized by four aspects. First, pluralism and linkages, where actors from government, resource users and industry represent various interests and perspectives on the issue or task across various scales. Second, communication and negotiation, specifically with regards to understandings and agreements being distributed through information sharing, as well as being able to be amended and modified by various actors. Third, transactive decision-making which is where decisions are made due to general consensus and takes into consideration various inputs and insight from actors. Fourth, social learning, where actors conduct activities together and share the consequences. Thus, learning may help to avoid mistakes in routines, while allowing for a quick reaction due to the values and policies of those routines, as well as serve as an essential guide for governing norms and protocols (Fennel et al., 2008).

Fennel et al. (2008) explained three ethical perspectives that are incorporated into adaptive co-management: deontology (right behavior), teleology (good behavior) and existentialism (authentic behavior).

\section{1) Deontology (right behavior)}

Deontological, or non-consequentialist, theories of ethics are theories focused on following duties, rules, or principles. This perspective gives guidance in reference to how people should behave, i.e., effective moral reasoning is founded on a sense of obligation that is tied strongly to such duties. Therefore, the most important aspect of this theory is moral principle and the importance of upholding morally established norms. Deontology covers religious sources of ethical behavior, as well as secular ones and intuition. Weaknesses of this perspective are that rules, principles and obligations may out of date or wrong from the viewpoint of some actors or outside parties. 


\section{2) Teleology (good behavior)}

Teleology focuses on the ends of activities. In this perspective, select activities are carried out in an effort to achieve the best ('good') outcomes. There are two major aspects of teleology: objective and subjective. Objective teleology is based on behavior that seeks good ends through the pursuit of excellence by means of a number of virtues. Subjective teleology is placed on decisions that maximize happiness for both the individual (hedonism) and the group (utilitarianism). This perspective serves as a guide for individuals to maximize positive outcomes.

\section{3) Existentialism (authentic behavior)}

The focus of this perspective is being true to oneself (authentic behavior). Existentialism has a broader insight than the other perspectives and decision making is not only to achieve the objectives of the group, but also for those related to humanity and natural resources.

Adaptive management is often used in conservation of natural resource efforts, especially with respect to actors meeting to review resource management responsibilities. Adaptive management is described as a two-phase process of deliberative and iterative phases. These processes are sequentially implemented over the timeframe of an objectives application through considering key elements, processes and issues in adaptive decision making.

The deliberative phase has five components including stakeholder involvement, objectives, alternatives, models and monitoring. Stakeholder involvement refers to the context and environment of an adaptive management project which influences both decision making and the opportunity to learn. However, adaptive decision making is not strict about the number and identity of stakeholders, nor about their perspectives or values. Objectives are expected to play an important role in evaluating performance, reducing uncertainty and improving management over time. Objectives should be clear, measurable and agreed-upon at the outset of an endeavor to guide decision making and assess progress in achieving management success. Management alternatives constitute a key element in the operating environment, in that the strategy choices in an adaptive management project are constrained by the set of available options. Furthermore, this could be meant that if these options fail to span a reasonable range of management activities or fail to produce recognizable and distinct patterns in system responses, adaptive management will be unable to produce effective and informative strategies. Models are related to potential management actions that play an important role in virtually all applications of structured decision making, whether adaptive or otherwise, as well as playing a key role in accounting for uncertainty. Monitoring in adaptive 
management inherits its focus and design from the larger management context of which it is a part (Williams, 2011).

The iterative phase consists of decision making, follow up, monitoring and feedback. There are many methods of selecting management actions, for example, the formal optimization method, less computation-intensive procedures, instances of decision analysis techniques, less formal approaches and common sense. Monitoring management, in the context of adaptive management, is seen as an ongoing activity which produces data to evaluate management interventions, update measures of model confidence and prioritize management options. The assessment of desired outcomes against actual outcomes can be used to evaluate the effectiveness of management and measure its success in achieving management objectives. Feedback gives opportunities for decision making, follow up and monitoring to be utilized as an iterative cycle. This sequence of activities is repeated over the course of an application, during which management actions are periodically adjusted based on what is learned in each of these activities (Williams, 2011).

Specifically related to the monitoring process in adaptive co-management, Cundill \& Fabricius (2009) proposed a methodological approach to monitoring that actively seeks to stimulate reflexive learning as a means of dealing with uncertainty in natural resource management. There are two main issues in the monitoring process: complexity and scale. Complexity in the adaptive system has unique characteristics, such as surprise, uncertainty, non-linearity, structure and function at the temporal and spatial levels. Monitoring criteria is considered to be a significant scale because the focus on just one scale might obscure important controlling processes at other scales. Table 6 shows the framework objectives for monitoring and evaluation in adaptive co-management.

Table 6 Framework objective

\begin{tabular}{|c|c|}
\hline Framework Objective & Key Themes \\
\hline $\begin{array}{l}\text { Performance evaluation in } \\
\text { complex systems }\end{array}$ & $\begin{array}{l}\text { - Systems-based on integrated social and ecological } \\
\text { variables } \\
\text { - Integrate variables inside and outside of local context } \\
\text { - Capture unexpected outcomes } \\
\text { - Focus on both process and performance } \\
\text { - Capturing fast and slow changing variables } \\
\text { - Capturing tangible and intangible outcomes } \\
\text { - Creating awareness about possible future trajectories } \\
\text { - Surrogates for measuring resilience }\end{array}$ \\
\hline
\end{tabular}




\begin{tabular}{|c|c|}
\hline $\begin{array}{l}\text { Promoting learning and } \\
\text { stakeholder buy-in }\end{array}$ & $\begin{array}{l}\text { - Collaborative monitoring and evaluation } \\
\text { - Collective understanding } \\
\text { - Conscious and deliberate learning processes } \\
\text { - Trust building } \\
\text { - Social change }\end{array}$ \\
\hline
\end{tabular}

Source: Cundill \& Fabricius, 2009

Co-management can also be seen as social learning for actors involved the process (Berkes, 2005; Cundil \& Fabricus, 2009). Berkes (2005) stated "Social learning is one of these tasks, essential both for the co-operation of partners and an outcome of the co-operation of partners. It occurs most efficiently through joint problem solving and reflection within learning networks. Through successive rounds of learning and problem solving, learning networks can incorporate new knowledge to deal with problems at increasingly larger scales, with the result that maturing co-management arrangements become adaptive co-management in time". Figure 2.1 is based on the work of a number of analysts who have suggested steps for policy-oriented monitoring (Babu \& Reidhead, 2000), collaborative monitoring design (Mahanty, Stacey, Holland, Wright, \& Menzies, 2007), social learning in environmental management (Keen, Brown, \& Dyball, 2005), participation in adaptive management (Stringer, et al., 2006) and general analyzing of co-management (Carlsson \& Berkes, 2005). A social learning approach to monitoring entails a cyclical process of problem identification, visioning, monitoring, taking action, reflection and redefining the problem (Table 6). The broad steps in this process include (Cundill \& Fabricus, 2009).

\subsection{Concepts for analyzing co-management}

\subsubsection{Concept of policy analysis: empowered deliberative democracy}

Policy analysis in this study refers to the research of Birner and Mappatoba (2004), which is focused on agreements within the conservation community in Central Sulawesi province using empowered deliberative democracy (EDD) approach. If the economic environment focuses on a normative evaluation of economic efficiency of the agreements reached during the establishment of collaborative management, so negotiation undertaken to reach agreements as part of a political process from the perspective of political science (Birner \& Mappatoba, 2004). Empirical studies indicate that the deliberative democracy models offer useful insight into the logic behind different agreements that are intended to 
unite communities and the state (Gaventa, 2002; Birner \& Mappatoba 2004; Meadowcroft, 2004; Fischer, 2006; Papadopolous \& Warin, 2007; Mustalahti \& Rakotonarivo, 2014).

The EDD was developed by Fung \& Wright (2001) to use in a number of cases that are designed to encourage ordinary people to become active in politics, as well as to sort out employment that is expecting. Additionally, the research of Fung and Wright explores a variety of responses from empirical a variety of responses from empirical studies to form a collection of real-world experiences which consider the energy and influence that communities have in problem solving. The study has frequently been used as a reference in the redesigning of democratic institutions and innovation. Eventually, EDD become a model for analyzing cases which have the potential to include radical democratic participation and the capacity which used to be one of the determining elements (Birner \& Mappatoba 2004; Fischer, 2006)

Five known experiments have investigated neighborhood governance councils by addressing the fears and expectations of citizens through adjusting bureaucracy in a given region and bestowing powers on communities: the Regional Training Partnership of Wisconsin has brought together labor, the management of companies and governments to provide training and to increase transparency in trantition term in order to help workers prepare to work in an increasing career in volatile economic times, Habitat Conservation Planning under the United States' Endangered Species Act is composed of a meeting with stakeholders in an effort to empower them to improve ecosystem management tactics to meet the various objectives of human development, as well as secure protection of endangered species. Budgeting Participation of Porto Alegre, Brazil enables citizens to participate directly in shaping the city budget and use available financial resources for the replacement and building of roads, as well as providing electricity in their area. India, through Panchyat reforms in West Bengal and Kerala, has created both direct and representative democratic channels that delegate substantial administrative and fiscal development power to individual villages. The fifth experiment has a different design, issue and scope, but has the same goalsto empower local people to participate in and influence the policy-making process throughout each process of deliberation. Similarity in purpose and many features such as the involvement of ordinary people, are used in the reform process of the empowered deliberative democracy/EDD (Fung \& Wright, 2001).

Conceptually, the EDD emphasizes the values of participation, deliberation and empowerment to the apparent limits of judgement and feasibility. Involving local people in the deliberation process has the potential to be radically democratic. The participation and capabilities of ordinary people can be highly dominance because they introduce reason-based 
decision making and feel empowered since they have an opportunity to tie action to discussion. The EDD also seeks to develop the current theory of democracy through several endeavors: (1) EDD brings many of its normative commitments from analyses of practices and values of communication, public justification and deliberation; (2) EDD is built in consideration of the importance of insight into civic life and non-governmental organization/s (NGO/s) to vigorous and effective democracy involving the recent body of work on civic engagement and secondary associations; (3) EDD is part of a broader collaboration intended to establish and envision democratic institutions that are at once more participatory and effective than the familiar configuration of political representation and bureaucratic administration. Three conventions in the context of reformation are dedicated to stabilizing and learning the basic principles of EDDs (1) the delegation of public decision authority to empowered local units; (2) the creation of formal linkages of responsibility, resource distribution and communication that connect these units to one another, as well as to as well as to establish more centralized authorities, more centralized authorities; and (3) the use and generation of new state institutions to support and guide these decentered problem solving efforts rather than leaving them as informal or voluntary affairs (Fung \& Wright, 2001).

\subsubsection{Concept of institutional dimension: participation, power sharing, and process}

The pattern of co-management is relevant for many cases of natural resource conflicts. The implementation of co-management is difficult, however, and contains many complex factors. Therefore, successful implementation of this approach must consider a comprehensive design including the key concepts of institutional dimension such as participation, power sharing and process (Sandström, 2009) .

Participation is an important issue for defining and analyzing co-management. This dimension is important to help identify who has the right to access and use a common resource, as well as who should be represented in the co-management arrangement. Identifying the important stakeholders is, however, not straightforward, and actors may disagree on the principles used to identify stakeholders (Sandström, 2009). There are three important elements related to participation mechanisms: who participates, how participants communicate with one another and make decisions together, and how discussions are linked with public policy or action. These dimensions are concerned with the scope of participation, modes of communication and decision, the extent of authority and forming an environment where specific mechanisms of participation are present. Different regions of this institutional design space are more and less suited to addressing important problems related to democratic 
governance, with regards to legitimacy, justice, and effective governance (Fung, 2006; Etzold, et al., 2012).

Power sharing is a significant aspect influencing a distributing of power for doing institutional analyzing of co-management. From the CPR theory, power sharing is often regarded as the starting-point or the focus around which the co-management arrangement is organized. All of the key actors involved must have a degree of influence in order for a situation to be defined as a co-management arrangement (Sandström, 2009).

The literature refers to the use of process dimension to analyze co-management depending on theories such as the CPR theory or management theory. Process dimension focuses on the rules, regulations, contextual variables and design principles that are present in a management agreement and tends to be relatively formal. The process dimension to analyze natural resource management is concerned with the process itself and is used as a tool to facilitate progress through deliberation, negotiation, development of social capital and trust (Sandstörm, 2009).

\subsubsection{Concept of property right}

Lambini \& Nguyen (2014) stated that a property right is integration of formal and informal rights and the authority to undertake particular actions related to a specific domain as panacea that linkage between institutional property rights and sustainable livelihoods. This definition focuses on differentiating between the rights and the rules, a tactic which is often used interchangeably in the utilization of natural resources. Ostrom (2005) emphasized the rights, especially at the level of analysis as a product of "rules" and, thus, not equivalent to rules. "Rights" in this context refers to particular actions that are authorized. For every right an individual holds, rules exist that authorize or require particular actions in exercising that property right (Schlager \& Ostrom, 1992). (Bromley, 2008) attempts to clarify the concept of property that so far had merely been defined in economic terms, specifically pertaining to the conditions necessary for the efficient functioning of markets; for example, physical objects such as dwellings, land or other possessions. Furthermore, it refers to the definition of property rights as the capacity to call upon the collective to stand behind one's claim to benefits (Agnello \& Donnelley, 1975).

\subsubsection{Concept of externality and transactional cost}

Issues within natural resource utilization can lead to negative impacts from external factors (Birner \& Mappatoba, 2002; Engel, Pagiola, \& Wunder, 2008). An understanding of these negative impacts are widely discussed in the field of economics, but there is no 
consensus which exactly area for definition and interpretation (Verhoeff, 1994; Wunder, Engel, \& Pagiola, 2008). Birner and Mappatoba (2002) defined these external effects as economic actions of agents affecting the production and consumption of others in a way which is not captured by the market mechanism. As a result of the absence of property rights (Baumol \& Oates, 1988), the theory of externalities is also frequently applied to environmental economics (Muradian, Corbera, Pascual, Kosoy, \& May, 2010). Moreover, Baumol and Oates (1998) explained "An external effect exists when an actor's (the receptor's) utility (or profit) function contains a real variable whose actual value depends on the behaviour of another actor (the supplier), who does not take these effects of his behaviour into account in his decision making process'”

For example, utilizing tropical rainforests for agricultural production causes a reduction in biological diversity (Birner \& Mappatoba, 2002). Clearing land for production and livestock activities can lead to increasing costs of agricultural production, thus affecting environmental health and agriculture (Tegtmeier and Duffy, 2004). Other externalities are caused by agricultural inputs such as pesticides on agricultural land degradation, fisheries, flora fauna, even accidental destruction of beneficial pest predators which increases the virulence of agricultural pests (Wilson \& Tisdell, 2001). However, externalities do not always lead to negative impacts and some even have positive effects (Lambin \& Meyfroidt, 2011). Three options promise to minimize the negative impacts and increase the positive impacts of externatilities: (1) the tax environment, (2) subsidies and incentives for reform, and (3) institutional mechanisms and participatory (Pretty et al., 2001; Pretty, Toulmin, \& Williams, 2011).

Transaction costs are a common example of external factors being present in environmental policy design. Therefore, a good choice of policy should have some degree of concern for transaction costs in order to the policy to achieve sustainability and efficiency. Transaction costs should be included in the measurement process or policy evaluation of natural resource management (McCann \& Easter, 2004; Armitage, et al., 2009). The concept of transaction costs was first introduced by Ronald Coase in 1937, where it is connected the study of transaction costs from an economic standpoint, to those in a market transaction. The concept has become a new paradigm in the field of economics and welfare (Karyoedi, 2006). Furthermore, information related to transaction costs have been implemented into various research efforts over the last several decades (Binner \& Mappatoba, 2004; McCann \& Easter, 2004; Garrick, Whitten, \& Coggan, 2013). 
The concept of transaction costs was initially introduced by Coase (1937) in his paper entitled "The Nature of the Firm". In this paper, Coase proposed that price mechanisms guide resource allocation effectively, but that these prices may or may not be routed through business or firm activities. (Coase, 1937) also argued that transaction costs influence the decisions of transactions within a company or even within the market. Several methods may be used to reduce transaction costs, including expense reduction activities, costs to minimize negotiations consisting of various contracts from different transaction (Karyoedi, 2006). Several options are available to measure transaction costs, these may be categorized accordingly: 1) integrating transaction costs into policy analysis; 2) defining transaction costs; 3) analyzing the effect of time on transaction costs; 4) analyzing the tradeoff between precision and measurement costs (McCann et al., 2005).

Measuring transaction costs by integrating costs into policy analysis should be done by including these costs into consideration of the larger framework of costs and benefits of the proposed policy. Most of studies in the literature conducted transaction cost measurements either explicitly or implicitly and assumes that the benefits provided by different policies are similar. Therefore, a cost-effective framework needs to be adequately developed, this does not always occur however. Some policies lead to a large number of benefits. It is important, however, to make a distinction between reducing transaction costs and improving efficiency. However, a policy should not to be rejected because it could be a relationship between transaction and costs. For example, a policy dedicated to reducing costs may have high transaction costs, while one dedicated to reducing transaction costs may increase overall costs. Transaction costs also need to be seen in the context of usefulness and policies being evaluated (McCann \& Easter, 2004). Transaction cost measurement in defining issues of transaction cost emphasizes on testing of transaction costs and not transaction costs. Measurements also requires to gain insights of policy implementation.

There is no consensus in the literature on a single definition for external effects (externalities), but the impacts of externalities are frequently taken into consideration in the field of economics. In general, external impacts are important factors to consider when describing a market failure. The term 'failure signal' is suggested to describe the types of market failure. Market prices do not reflect social costs (benefits) or additional taxes (subsidies) required to maintain efficient work (Verhoef, 1994). In general, the impact of externalities is found in the absence of property rights (Gehring, 2013; Menell \& Meurer, 2013). Thus, the theory of externalities is often applied in instances related to environmental aspects. Environmental quality is a trait in which property rights are not defined or are not equated with market (Verhoef, 1994). 


\subsubsection{Concepts of sustainability ecotourism}

Some of the existing definitions of ecotourism leave much room for interpretation, but the majority more or less agree on the following criteria: 1) attraction should be predominantly nature-based, 2) visitor interactions with attractions should be focused on learning or education, and 3) experience and product management should follow principles and practices associated with ecological, socio-cultural and economic sustainability (Weaver \& Lawton, 2007; Weaver, The encyclopedia of ecotourism, 2001). Fennell (2003) stated that ecotourism is "'where many places and people independently respond to the need for more nature travel opportunities in line with society's efforts to become more ecologically minded". (Walpole \& Goodwin, 2000) further elaborated on the definition of nature tourism and ecotourism by suggesting that nature tourism encompasses all forms of tourism, including mass tourism, adventure tourism, low impact tourism and ecotourism which uses natural resources in a wild or undeveloped manner, often with the inclusion of species, habitats, landscapes, scenery and salt and fresh-water features, but may also be used for the purpose of travel or simply for enjoying undeveloped natural areas or wildlife. Conversely, ecotourism is considered to be a low impact type of nature tourism which contributes to the preservation of species and habitats either directly through a contribution to conservation and/or indirectly by providing revenue to the local community (Coria \& Calfucura, 2012). This revenue should be sufficient for local people to value and, therefore, protect their wildlife heritage area as a source of income (Gurung \& Seeland, 2008; Liu, et al., 2014). Wallace \& Pierce (1996) suggest that the key principles of ecotourism include:

1) Minimize negative impacts to the environment and local people

2) Increase awareness and understanding of an area's natural and cultural systems, along with encouraging the subsequent involvement of visitors in issues affecting those systems

3) The conservation and management of legally protected and other natural areas

4) The early and long term participation of local communities in the decision-making process in an effort to determine what types and what amount of tourism should occur

5) Directing economic and other benefits to local people to complement, rather than replace, traditional practices (farming, fishing, social systems, etc.).

6) Provision of special opportunities for local people and nature tourism employees to utilize and visit natural areas, while learning more about the wonders that visitors come to see

The key points of the following key elements are essential for ecotourism: interest in nature, contribution to conservation, reliance on parks and protected areas, benefits to local 
people (short and long term), education and study opportunities, low impact/non consumptive, ethics, responsibility, management, sustainable, enjoyment/appreciation, culture, adventure and small scale bussiness. Lindberg (1991) emphasized the importance of dedication and time as a function of defining the various types of eco-tourists, including what tourists wish to gain/experience from ecotourism, where they wish to travel and how they wish to travel. Lindberg identified four basic types of eco-toursists:

1) Hard-core nature tourists: scientific researchers or members of tours specifically designed for education, litter removal, or other similar purposes;

2) Dedicated nature tourists: people who take trips specifically to see protected areas and who want to understand the local nature and the cultural history of the area;

3) Mainstream nature tourists: people who visit the Amazon, the Rwandan gorilla park, or other destinations primarily to take an unusual trip; and

4) Casual nature tourists: people who experience nature incidentally as part of a broader trip. 


\section{Chapter III. Research Methods}

\subsection{Literature study and research design}

\subsubsection{Literature study}

The initial literature review was completed by searching for, collecting and examining available literature sources related to the research topic. The literature sources cover literature from journals, scientific working papers, books, magazines and reports. The literature review was supported with information made available by universities, study centers, national and local governments, non-government organizations, statistic bureaus and online sources.

Main literature was provided by universities such as University of Goettingen-Germany, Bogor Agricultural University-Indonesia, and University of Jambi-Indonesia, Literatures were also gathered from Center of Rural and Development Studies at Bogor Agricultural University, NGO Warsi in Jambi, NGO Flora \& Fauna Indonesia in Kerincy Regency, and NGO Lembaga Tumbuh Alami, Sumatra in Sungai Penuh city, Kerinci Regency. The secondary data was also supported by local and national governments consisting of District Forestry and Plantation Office (Dinas Kehutanan dan Perkebunan Kabupaten Kerinci), District Tourism Office (Dinas Pariwisata Kabupaten Kerinci) and District Regional Development Planning Board Office (Kantor Badan Perencanaan Pembangunan Daerah Kabupaten Kerinci), the office of the Kerinci Seblat National Park authority in Sungai Penuh city, the library of Jambi Province, Directorate of Environmental Services in Conservation Area and Protected Forest Office in Bogor (Kantor Direktorat Jasa Lingkungan dan Perlindungan Hutan), Indonesian Institute of Science in Jakarta, Jambi Provincial Central Bureau of Statistic of Jambi Province and Central Bureau of Statistic of Kerincy Regency, online literatures also the other source of secondary data such as iist.org, conservation.org, wcs.org, iucn.org, unesco.org, conservationandsociety.org, sciencedirect.com, eau.sagepub.com, bione.org, onlinelibrary.wiley.com, link.springer.com, journals.elsevier.com, jstor.org.

The literature review is focused on interactions among stakeholders and the relationship between stakeholders and the conservation area. There are three fundamental questions that addressed literature-based studies: (1) perceptions and interactions of local communities, for example, with the conservation areas of rainforests in the context of collaboration management. These perceptions and interactions were evaluated in the first step of the research; (2) the role of formal institutions, local government, and national government agency, which perceive and implement policies in the protected and surrounding areas. 
Synergy amongst these institutions is necessary because it influences forest conservation and the welfare of the local community. Perceptions of each actor regarding the protected area, along with the degree of involvement of the local people in economic development become a crucial aspect of co-management; (3) the benefits received by the local people as a result of the national park, especially with respect to developing local economies to a point where sustainability can be reached.

Perspectives of conservation, interaction and collaboration were used in order to investigate the relationships between stakeholders and the protected area. Tabel 7 describes the link upon research question, perpsectives approach and literature sources.

Table 7 Research question, perspectives approaches, and literatures sources

\begin{tabular}{|c|c|c|}
\hline Research question & Perspectives & Literatures sources \\
\hline $\begin{array}{l}\text { Whether the perception and social } \\
\text { interaction built by the local } \\
\text { community, national park } \\
\text { managers, and other stakeholders } \\
\text { can provide opportunities for the } \\
\text { formation of a collaborative } \\
\text { management built on mutual } \\
\text { respect and mutual benefit, and } \\
\text { whether it can be sustainable? }\end{array}$ & $\begin{array}{l}\text { - Institutional } \\
\text { dimention } \\
\text { (participation, process } \\
\text { and interaction ) }\end{array}$ & $\begin{array}{l}\text { Sandström, } 2009 \\
\text { Engel, S., C. Palmer, A. } \\
\text { Pfaff (2013) }\end{array}$ \\
\hline $\begin{array}{l}\text { Whether the local culture } \\
\text { established in the local } \\
\text { community can be a foundation } \\
\text { for the formation of a } \\
\text { collaborative pattern among } \\
\text { stakeholders and can strengthen } \\
\text { the bargaining position of local } \\
\text { communities on the created } \\
\text { collaborative management and, }\end{array}$ & $\begin{array}{l}\text { - Institutional } \\
\text { dimention } \\
\text { (participation, process } \\
\text { and interaction ) } \\
\text { - Adaptive } \\
\text { collaboration }\end{array}$ & $\begin{array}{l}\text { Sandström, } 2009 \\
\text { Berkes, F (2009) }\end{array}$ \\
\hline
\end{tabular}




\begin{tabular}{|c|c|c|}
\hline $\begin{array}{l}\text { furthermore, if it can be relied } \\
\text { upon to preserve and protect the } \\
\text { biodiversity of Kerinci Seblat } \\
\text { National Park? }\end{array}$ & & \\
\hline $\begin{array}{l}\text { How to linkage implementation of } \\
\text { co-management towards } \\
\text { politically and economically } \\
\text { development of Kerinci Regency? }\end{array}$ & $\begin{array}{l}\text { - Perspective of } \\
\text { economy and } \\
\text { environment }\end{array}$ & $\begin{array}{l}\text { Selfer, T.J., Endter-Wada } \\
\text { (2008) } \\
\text { Mehring, M., C. Seeberg- } \\
\text { Elverfeldt, S. Koch, J. } \\
\text { Barkmann et al. (2011) }\end{array}$ \\
\hline $\begin{array}{l}\text { Can the potential of ecotourism in } \\
\text { and around the protected areas } \\
\text { build a collaborative management } \\
\text { effort among stakeholders, } \\
\text { particularly one that involves the } \\
\text { local community? }\end{array}$ & $\begin{array}{l}\text { - Perspective of } \\
\text { economy and } \\
\text { environment } \\
\text { - Adaptive } \\
\text { collaboration }\end{array}$ & $\begin{array}{l}\text { Selfer, T.J., Endter-Wada } \\
\text { (2008) } \\
\text { Birner, R., M. Mappatoba } \\
\text { (2003) } \\
\text { Burkard, G (2007) }\end{array}$ \\
\hline
\end{tabular}

\subsubsection{Research design}

This study used a case study approach to apply the research methods of qualitative social sciences (Mehring, 2011). Qualitative research method was chosen because it provides strategies and ways to collecting and analyzing the data from natural setting (Matthew, 1994). This study also used multiple methods of collection, compilation and data analysis for both primary and secondary data, this is frequently referred to as the triangulation method. Data triangulation may cover person, place and time. Triangulation observations are better than single observations with the same object. For this work, multiple theories are better than having only one perspective of the same object settings (Berg, 2007).

Figure 4 shows the research framework that describes the individual steps of the current research, along with the methods used to obtain secondary and primary data. This method is used to elaborate on the concept of sustainable collaborative management in protected areas and to analyze the benefits for the local community and other stakeholders in Kerinci Regency. 


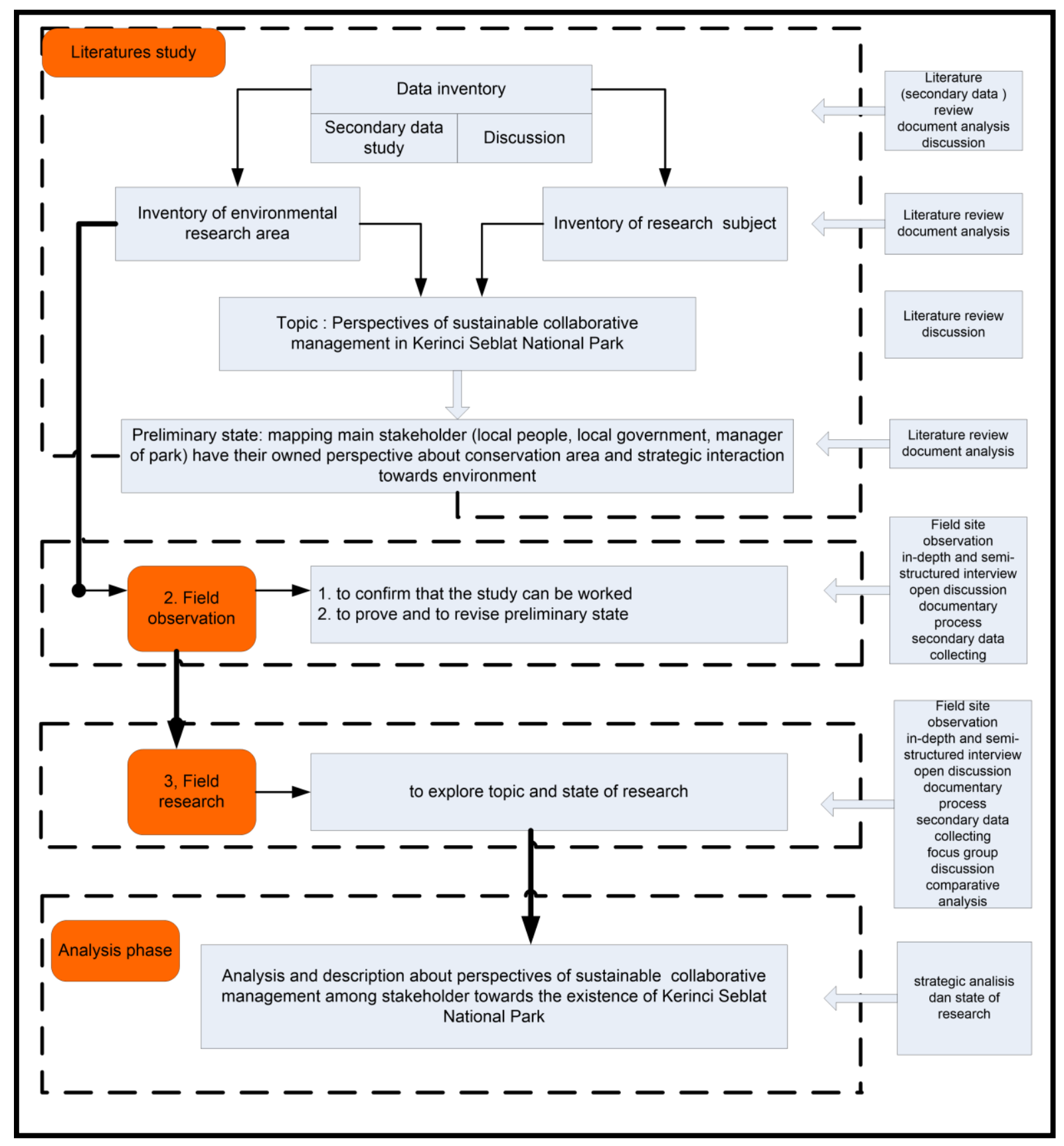

Figure 4 The research design

Figure 4 elaborates on the research design of this study, which is broadly divided into four stages, and was conducted from 2012 to 2015. The first stage includes a pre-survey in which the activities were focused on a completed literature review and the collection of other secondary data; this was completed between 2012 and 2014. The second stage was observation and initial field work. The third stage was the second round of field work focused primarily on the collection of primary data. The primary data in this investigation was obtained by interviewing respondents and conducting focus group discussions (FGD) in 
selected reference villages. The fourth stage is the analysis and the full description of the secondary and primary data.

The triangulation approach was used in the present work for the confirmation of both primary and secondary data. The method was carried out several times in an effort to obtain complete information based on respondent perceptions and interactions with the topic proposed in this research (Berg, 2007). The triangulation method indicates that each alternative method has strengths and weaknesses (Johnson \& Onwuegbuzie, 2004; Johnson, Onwuegbuzie, \& Turner, 2007). Therefore, the research method was used in combination with sources, methodology and research members. Data, information, opinions and suggestions were obtained and processed by collecting, compiling, analyzing and presenting the data. Collecting and compiling the data was done through a complete review of the literature, including case studies, interviews, open discussions, observations and field research, documentary research, critical reviews, comparisons and focus group giscussions (FGD). Analysis and presentation of data was completed through the use of descriptivequalitative analysis and content analysis in an effort to fully analyze relevant policies.

Referring to the legal domain of social research which includes descriptive-qualitative characteristics, the collected data was obtained through the survey approach, while secondary data was analyzed and directly explain detailed data from participants' responses which were purposefully based on their expertise and knowledge. Secondary data was collected by searching, identifying and analyzing a variety of reports related to this research topic. The relevant secondary data was therefore published in either academic or scientific circles and is accountable. Primary data was collected according to the following list:

(1) Observation was conducted for the research site through the mapping and identification of social and economic conditions, as well as the management activities of the conservation area

(2) Participants' responses were used to determine the perception, participation level, degree of social interaction and opinion regarding the patterns of collaborative management according to participants in the villages in the surrounding conservation areas. The utilized surveys were administered by distributing the structured interviews to people in these villages surveys were conducted by distributing are quistionary and the conducting structured interviews

(3) Open discussions were conducted to gather additional information from additional participants, outside of the selected respondents

(4) Focus group discussions were conducted in small groups in the four villages that were selected as reference villages, and held in the park authority office in Sungai Penuh city 
The data and information collected through the descriptive analysis approach in which the obtained information was described and presented as a strategy option to identify collaborative patterns desired by the respondent or informant.

\subsection{First fieldwork journey as fitting reasearch approach}

Fieldwork method is a technique for collecting data that is working with people for long periods of time in a natural setting. This method approach will avoid the artificial response typical of controlled or laboratory conditions. Fieldwork is a research approach which is sometimes more difficult than the work in the laboratory. Reviews these methods and techniques objectify and standardize the researcher's perceptions. Resource constraints and deadlines also may limit the length of time for the data gathering in the field-exploring, cross-checking, and recording information (Bickman \& Rog, 1998).

The first stage of field research trip is observation to Kerinci Regency. This step was conducted through field visits to determine whether the topic is relevant to the selected research sites. Observations were also made based on interviews with key respondents: Head of District Tourism Office, Head of District Forestry and Plantation Office, Staff of District Tourism Office, Staff of District Forestry and Plantation Office, KSNP manager staffs, leader community and head of village in Lempur Village, Lindung Jaya Village, Pelompek Village, Sanggaran Agung Village, Owner and Manager of Hotel and Motel in Kayu Aro Sub-district, two staffs of Warsi Non Government Organizations (Warsi NGOs), Perhutani Staffs (State Forest Enterprise Staffs), and Academicians at University of Jambi, Bogor Agricultural University (Institut Pertanian Bogor). Primary and secondary data were further elaborated on in the form of location mapping as a basis for the next steps. The emphasis of this observation stage were to map the location and interview key respondents.

Primary data and all of the information gathered at this stage were further elaborated on through the use of secondary data as a basis for the next steps (field research). Primary data and information which were collected in the observation stage were then processed and combined with secondary data to be used as material during research visits conducted at a later stage. 
Table 8 Administrative level, stakeholder, research technique, and issued addressed

\begin{tabular}{|c|c|c|c|}
\hline $\begin{array}{l}\text { Administrative } \\
\text { level }\end{array}$ & Stakeholder & Research technique & Addressed issue \\
\hline National & National agency & $\begin{array}{l}\text { - semi-structured } \\
\text { interview }\end{array}$ & administration and management of protected area \\
\hline Provincial & $\begin{array}{l}\text { Local government } \\
\text { (governoor official, provincial tourist } \\
\text { official) }\end{array}$ & $\begin{array}{l}\text { - } \text { open discussion } \\
\text { - } \text { semi-structured } \\
\text { interview }\end{array}$ & $\begin{array}{l}\text { management issue of affecting park } \\
\text { Interaction with local community and stakeholder }\end{array}$ \\
\hline \multirow[t]{2}{*}{ Regency } & $\begin{array}{l}\text { Local government } \\
\text { (major regency official, forestry and } \\
\text { plantation official, regional development } \\
\text { planning board, tourist and cultural } \\
\text { official) }\end{array}$ & $\begin{array}{l}\text { - } \text { open discussion } \\
\text { - } \text { semi-structured } \\
\text { interview }\end{array}$ & $\begin{array}{l}\text { administration and management of protected area } \\
\text { management issue of affecting park } \\
\text { perception of park } \\
\text { interaction with local community and stakeholder }\end{array}$ \\
\hline & National agency (the KSNP manager) & $\begin{array}{l}\text { - open discussion } \\
\text { - semi-structured } \\
\text { interview } \\
\text { - FGD }\end{array}$ & $\begin{array}{l}\text { administration and management of protected area } \\
\text { perception of park } \\
\text { management issue of affecting park } \\
\text { interaction with local community and stakeholder }\end{array}$ \\
\hline District & $\begin{array}{l}\text { Local government } \\
\text { (head of distrcit office) }\end{array}$ & - open discussion & $\begin{array}{l}\text { management issue of affecting park } \\
\text { interaction with local community and stakeholder } \\
\text { perception of park } \\
\text { view on conservation }\end{array}$ \\
\hline Village & $\begin{array}{l}\text { Local people } \\
\text { (head of villages, leader of community, } \\
\text { local coomunity) }\end{array}$ & $\begin{array}{l}\text { - } \text { open discussion } \\
\text { - } \text { semi-structured } \\
\text { interview } \\
\text { - FGD }\end{array}$ & $\begin{array}{l}\text { perception of park } \\
\text { awarennes of park and regulation } \\
\text { agroforest activities } \\
\text { interaction with official } \\
\text { view on conservation }\end{array}$ \\
\hline & $\begin{array}{l}\text { Ecotourist, businessman (owner) } \\
\text { NGO's, management of PTPN VI, } \\
\text { academicians }\end{array}$ & - open discussion & conservation and park management issues \\
\hline
\end{tabular}




\subsection{Setting research villages and procedures selecting respondent}

This study was conducted in Kerinci Regency located in KSNP (enclave). The Regency is one of the 9 regencies within KSNP. Kerinci Regency has an area of 305,000 ha and is comprised of 16 sub-districts. Table 9 describes 16 of the Sub-districts and their areas, while Map 1 illustrates the location of Kerinci Regency in relation to KSNP.

Table 9 The area of Kerinci Regency

\begin{tabular}{|c|c|c|c|}
\hline No & Sub-district & Area (Ha) & \% \\
\hline 1 & Gunung Tujuh & 15.963 & 4.8 \\
\hline 2 & Kayu Aro & 11.517 & 3.46 \\
\hline 3 & Kayu Aro Barat & 20.665 & 6.21 \\
\hline 4 & Gunung Kerinci & 30.687 & 9.22 \\
\hline 5 & Siulak & 14.287 & 4.29 \\
\hline 6 & Siulak Mukai & 27.431 & 8.24 \\
\hline 7 & Air Hangat Barat & 1.415 & 0.43 \\
\hline 8 & Air Hangat & 21.087 & 6.43 \\
\hline 9 & Air Hangat Timur & 18.229 & 0.88 \\
\hline 10 & Depati VII & 2.913 & 1.74 \\
\hline 11 & Sitinjau Laut & 5.807 & 6.8 \\
\hline 12 & Danau Kerinci & 22.626 & 10.96 \\
\hline 13 & Keliling Danau & 36.484 & 6.4 \\
\hline 14 & Bukit Kerman & 21.294 & 10.45 \\
\hline 15 & Gunung Raya & 34.763 & 14.32 \\
\hline 16 & Batang Merangin & 47.646 & 332.842 \\
\hline
\end{tabular}

Source: Government of Kerinci Regency, 2009 


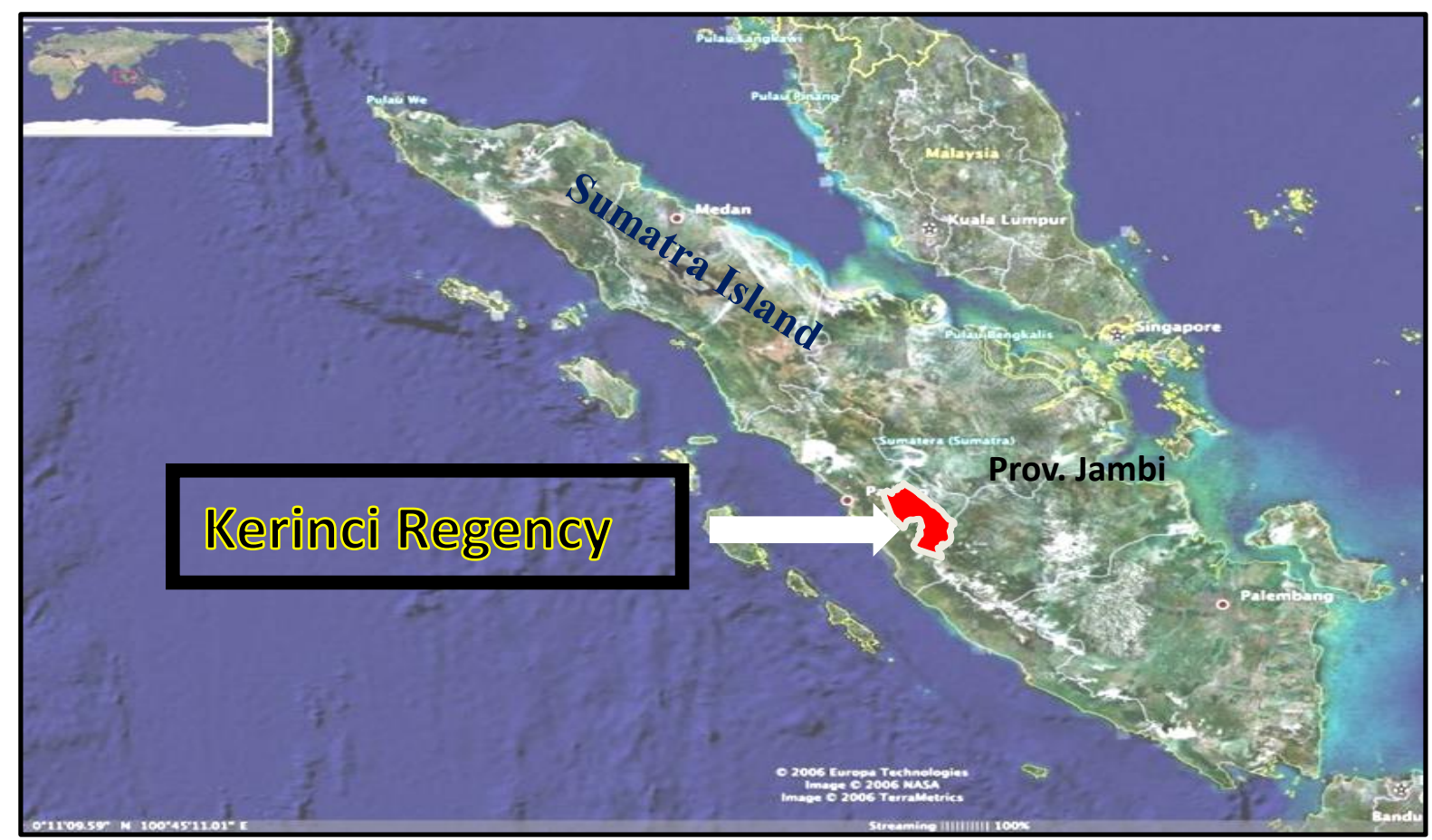

Source: Government of Kerinci Regency, 2009

\section{Map 1 Kerinci Regency teritory}

Kerinci Regency and Kerinci Seblat National Park (KSNP), specifically, were selected as the research area to evaluate collaborative management for several reasons. First, most of Kerinci Regency (52\%) is located within the KSNP area. KSNP is the largest national park in Sumatra and is spread out across four provinces. Second, the national park has the greatest biodiversity and the most complete tropical rainforests that cover both lowland and highland areas. The extensive biodiversity is one of the primary reasons that this location was selected for evaluation. Third, Kerinci Regency and KSNP have substantial ecotourism capabilities and may serve as a driver to improve the welfare of local communities, as well as being a critical collaboration point among stakeholders. Fourth, Kerinci Regency is located in the middle of the Bukit Barisan mountain chain, or enclave. Therefore, interactions within the community have a unique and long history. The local people interact with and depend on the forest. The final reason for this selection, is the perception and interaction of local communities. Many situations have affected their behavior to the protected area. As a result, there are some conflicts in many locations are the region. In fact, local people currently do not 
have access to the indigenous forest, although the forest has been categorized as an indigenous forest.

Some conflicts between the indigenous people of Kerinci and immigrants are caused by differences in perspective and maintenance habits within the forest. Moreover, immigration issues affected land tenure and inter-ethnic conflicts in the 2000s when the reformation era in Indonesia was beginning. These conflicts occur not only horizontally, but also vertically. Therefore, KSNP was chosen as project location related to handling social and natural resources conflicts for several times. Some conflicts have involved actors such as local government and the KSNP manager in terms of how to best utilize KSNP to achieve a winwin situation.

Based on the above considerations and in an effort to further facilitate this research, four villages around the KSNP area and the administrative regency of Kerinci have been chosen to obtain an even more in-depth understanding. These four villages were chosen based on several factors: first, the interaction between local communities either directly or indirectly related to the existence of KSNP. Second, village location was determined by deliberately selecting those which were either directly or indirectly in the KSNP region. Third, the two reasons previously expected to help focus research how to investigate and explain collaboration patterns among major stakeholders (local communities, local authorities and the KSNP managers) for sustainable use and management of KSNP. Fourth, the KSNP management is based on customary law. Table 10 indicates the names of the villages and their respective areas. Map 2 ilustrates four selected villages for studying.

Table 10 The name of selected Sub-district and Village

\begin{tabular}{|l|l|l|l|l|}
\hline No & Sub-district & Areas (Ha) & Village & Areas (Ha) \\
\hline 1. & Gunung Tujuh & 16,250 & Pelompek & 150 \\
\hline 2. & Kayu Aro & 32,805 & Lindung Jaya & 150 \\
\hline 3. & Danau Kerinci & 29,847 & Sanggaran Agung & 1,882 \\
\hline 4 & Gunung Raya & 74,677 & Lempur Tengah & 5,576 \\
\hline
\end{tabular}

Source: Statistics of Kerinci Regency, 2013 


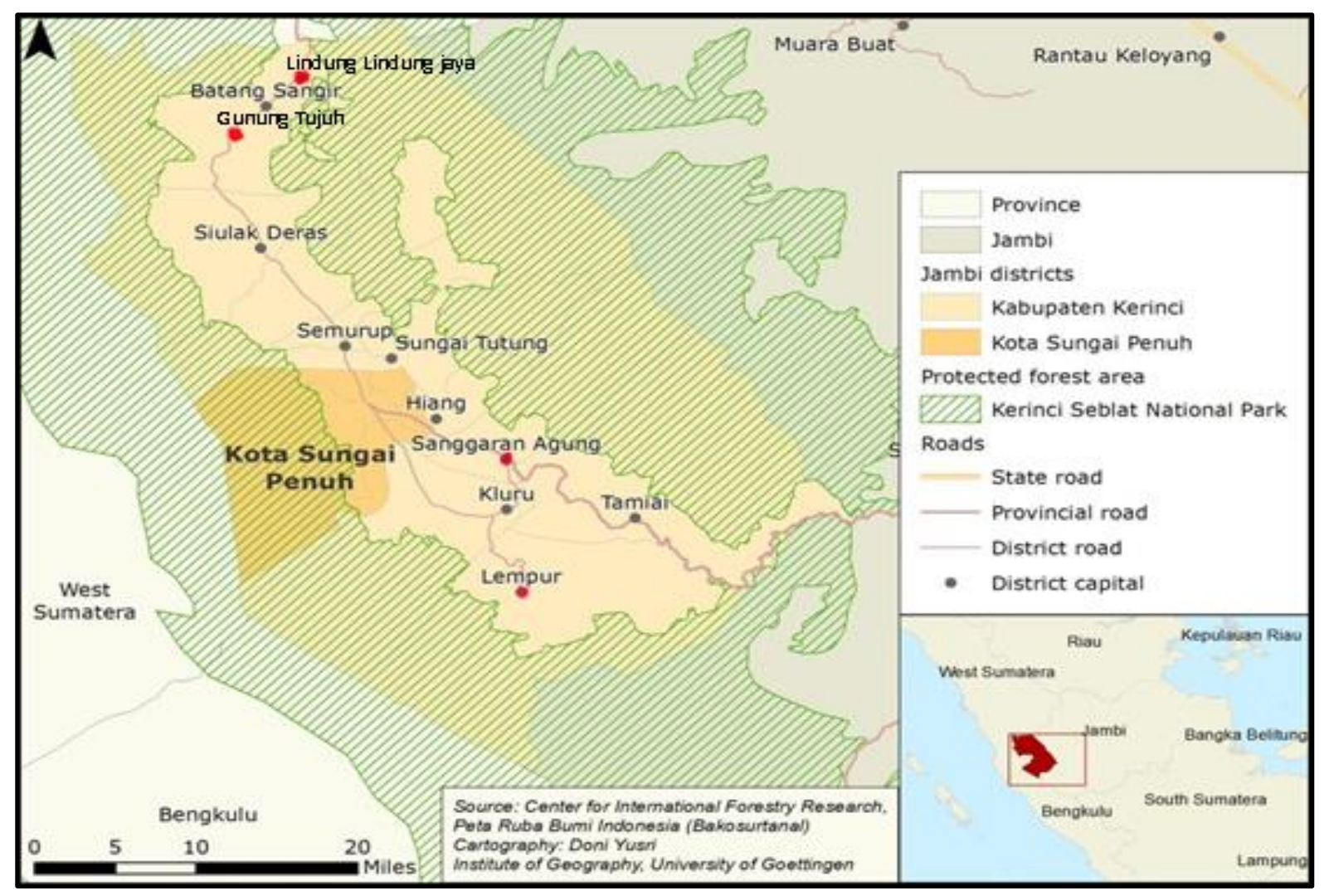

Map 2 Location of four villages selected to study

\subsection{Data collection devices determinator for collaborative management}

\subsubsection{Second fieldwork research to primary collecting data}

The next step was field research which was conducted from August to November 2014 and serves as a key component of the research. This step focused on collecting primary data through in-depth interviews, open discussion and FGDs. In qualitative research, there are two types of interviews: semi-structured and structured. A semi-structured interview is an open discussion with selected respondents. The main questions were prepared prior to each interview and were posed in a manner that would obtain in-depth information. A structured interview is an interview in which respondents answer the given questions in a sequential manner. The objectives of in-depth interviews in this research are to acquire a full understanding of the complexities of certain problems, explore data and information and collect opinions and suggestions related to the perception of collaborative management in KSNP. After the in-depth interviews, FGDs were conducted to further clarify the data and to explore which sub-topic(s) may need to be further elaborated on. 
The first step to conduct such interviews is to establish a selection process, including the determination of key respondents who have expertise on the research topic and have information that would be useful to give to other respondents, often called the Snowball Interview Approach. The selection of key respondents was based on the following criteria: knowledge and experience about the existence of KSNP and Kerinci Regency, having a broader view and greater amount of information and an ability to analyze vision, policy and goals related to the government and local people. The key participants are classified into two groups: formal leaders, such as head of sub-district or the head of village, and informal leaders such as religious leaders, cultural leaders and youth leaders. The selected key respondents were cultural leaders called depati, head of village, head of sub-district, head of district, head of the Forestry and Agriculture department, Governor of Jambi Province, the KSNP manager, NGOs, academic scholars and the General Director of PTPN VI.

The interview technique for the key respondents was slightly different than that of standard interviews. Here, key respondents were given in-depth interviews using a topicspecific questionnaire. Semi-structured interviews were conducted by asking the respondents a series of questions. The interview process utilized tools such as a tape recorder, video recorder and camera in an effort to collecting data. Visual and audio records were made by the researcher.

Table 11 Stakeholder, respondents, and number of respondent

\begin{tabular}{|c|c|c|c|c|}
\hline \multirow{2}{*}{ Stakeholder } & \multirow{2}{*}{ Respondents } & \multicolumn{2}{|c|}{ Number of respondent } & \multirow{2}{*}{$\begin{array}{l}\text { Total number of } \\
\text { respondent }\end{array}$} \\
\hline & & Observation & Field work & \\
\hline \multirow{7}{*}{$\begin{array}{l}\text { Government } \\
\text { (national } \\
\text { agency and } \\
\text { local } \\
\text { government) }\end{array}$} & $\begin{array}{l}\text { Head of directorate of } \\
\text { environmental services } \\
\text { in conservation area and } \\
\text { protected forest office }\end{array}$ & - & 1 & 1 \\
\hline & $\begin{array}{l}\text { Governor of Jambi } \\
\text { province }\end{array}$ & - & 1 & 1 \\
\hline & PTPN VI officer & - & 2 & 2 \\
\hline & Head of regency & - & 1 & 1 \\
\hline & $\begin{array}{l}\text { National agency (the } \\
\text { KSNP authority) }\end{array}$ & 5 & 15 & 20 \\
\hline & $\begin{array}{l}\text { Local government (local } \\
\text { forestry and plantation } \\
\text { officer) }\end{array}$ & 3 & 8 & 11 \\
\hline & $\begin{array}{l}\text { Local government (local } \\
\text { tourist and cultural }\end{array}$ & 3 & 5 & 8 \\
\hline
\end{tabular}




\begin{tabular}{|c|c|c|c|c|}
\hline & officer) & & & \\
\hline & $\begin{array}{l}\text { Local development } \\
\text { planning official }\end{array}$ & 1 & -- & 1 \\
\hline & Head of District & 2 & 4 & 6 \\
\hline & $\begin{array}{l}\text { State owned forestry } \\
\text { official }\end{array}$ & 15 & - & 15 \\
\hline \multirow{3}{*}{$\begin{array}{c}\text { Local } \\
\text { community }\end{array}$} & Head of village & 4 & 7 & 11 \\
\hline & Leader of community & 5 & 7 & 12 \\
\hline & Local people & 7 & 25 & 27 \\
\hline Private & Hotel owner & 3 & 3 & 6 \\
\hline \multirow{3}{*}{ NGO’s } & $\begin{array}{l}\text { LSM Flora \& Fauna } \\
\text { Indonesia }\end{array}$ & - & 5 & 5 \\
\hline & LSM Warsi & 2 & -- & 2 \\
\hline & LSM LTA & - & 1 & 1 \\
\hline Academition & Academist & 5 & 8 & 13 \\
\hline Tourist & Ecotourist & 2 & 10 & 12 \\
\hline \multicolumn{2}{|c|}{ Total number of respondent } & 42 & 98 & 160 \\
\hline
\end{tabular}

In total, there were 160 respondents that took part in either the observation and/or the field work aspects of the research. Most of these respondents came from Kerinci Sub-districts and consisted of local communities, community leaders, national, provincial and district government staff members, academic scholars and NGO activists.

\subsubsection{Participant rural appraisal}

\subsubsection{Participant observation}

Participant observation enables fieldwork done effectively because it is an effort that combines between community life and study limitation that allows observation and recording of sufficient data (Bickman, 1998). The observations can be made openly or under the role of research carried out secretly by undercover role of observing things that happen, listen to what is said, and asked people, within a certain time limit (Becker \& Gee, 1957; Bernard \& Gravlee, 2015). Participant observation should be made within a few months thus may help researchers internalize the basic beliefs, fears, hopes, and expectations of the targeted community, learned the language and look for patterns of behavior over time (Becker \& Gee, 1957; Tedlock, 1991; Bickman \& Rog, 1998).

In this study, participant observation approach focuses in four villages addressed to get knowledge, understanding and developing a range of research topics related questions. In all 
four villages, researcher developed participant observation related to the use, management and access to natural resources in the environment of local community. In addition, the approach also carried out on the KSNP manager. When participant observation conducted, researchers followed several times community meetings amongst community leaders in several events either organized by the local community as well as those held outside the local community.

Related to the meetings, researchers took part in the informal meeting among some of the head of villages in Kayu Aro Sub-district and Gunung Tujuh Sub-district. The informal meeting is not a regular and routine meetings among them. But the meeting suddenly done is an informal Meeting (Forum Silaturahmi) among the village chiefs. It is intended to exchange information, and is usually performed as an interlude before attending cultural events. Another meetings, that researcher was participating, are a meeting initiated by the Jambi Provincial Tourism Office in cooperation with the indigenous peoples in Lempur Tengah Village which is the main purpose is to discuss the initiation or establishment of indigenous Villages for the Lempur Tengah Village. This forum is quite large and attended by representatives of all villages in the sub-district of Gunung Raya.

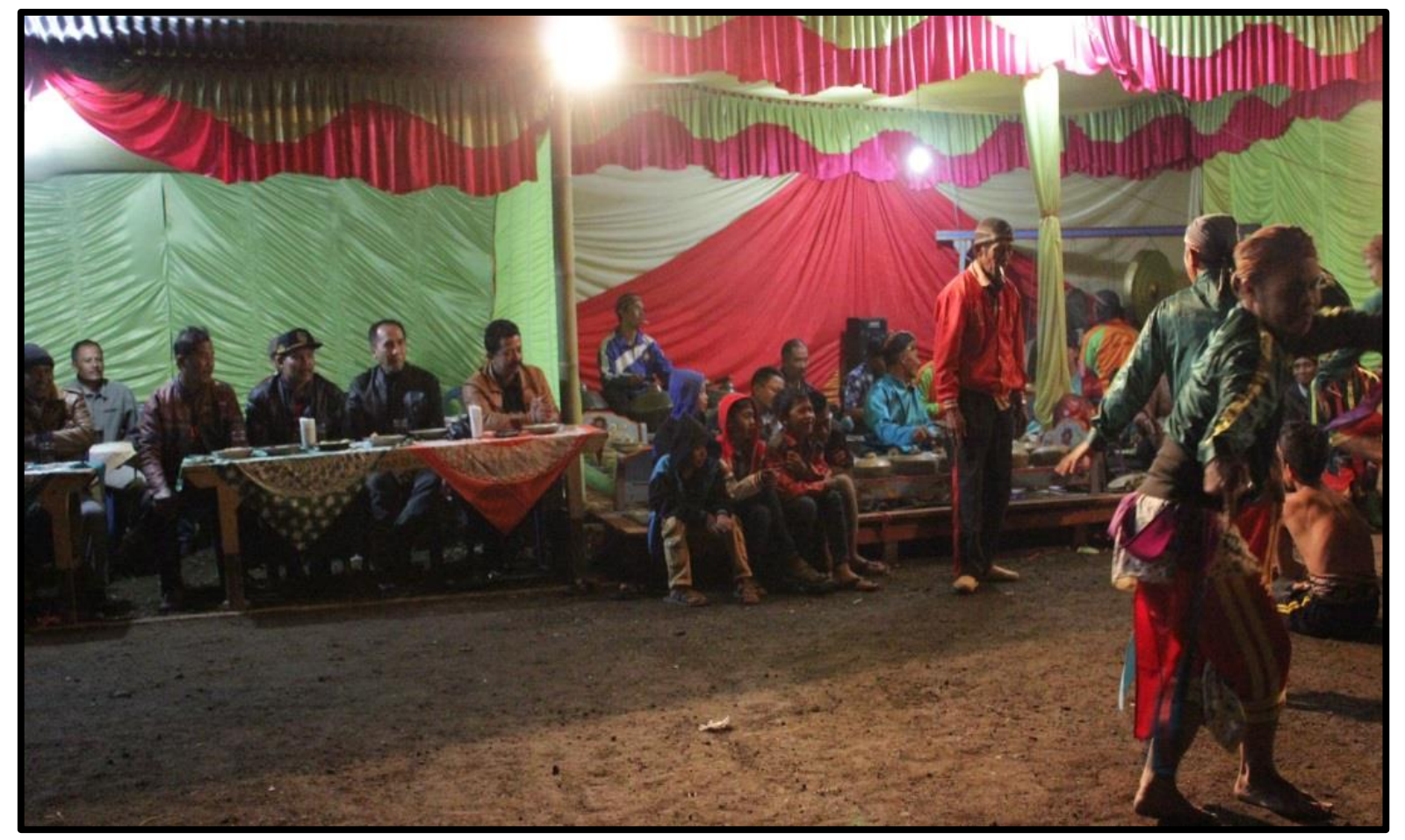

Source: Author's Photo

Picture 1 A traditional event of Javanisch community in Kayu Aro Sub-district 


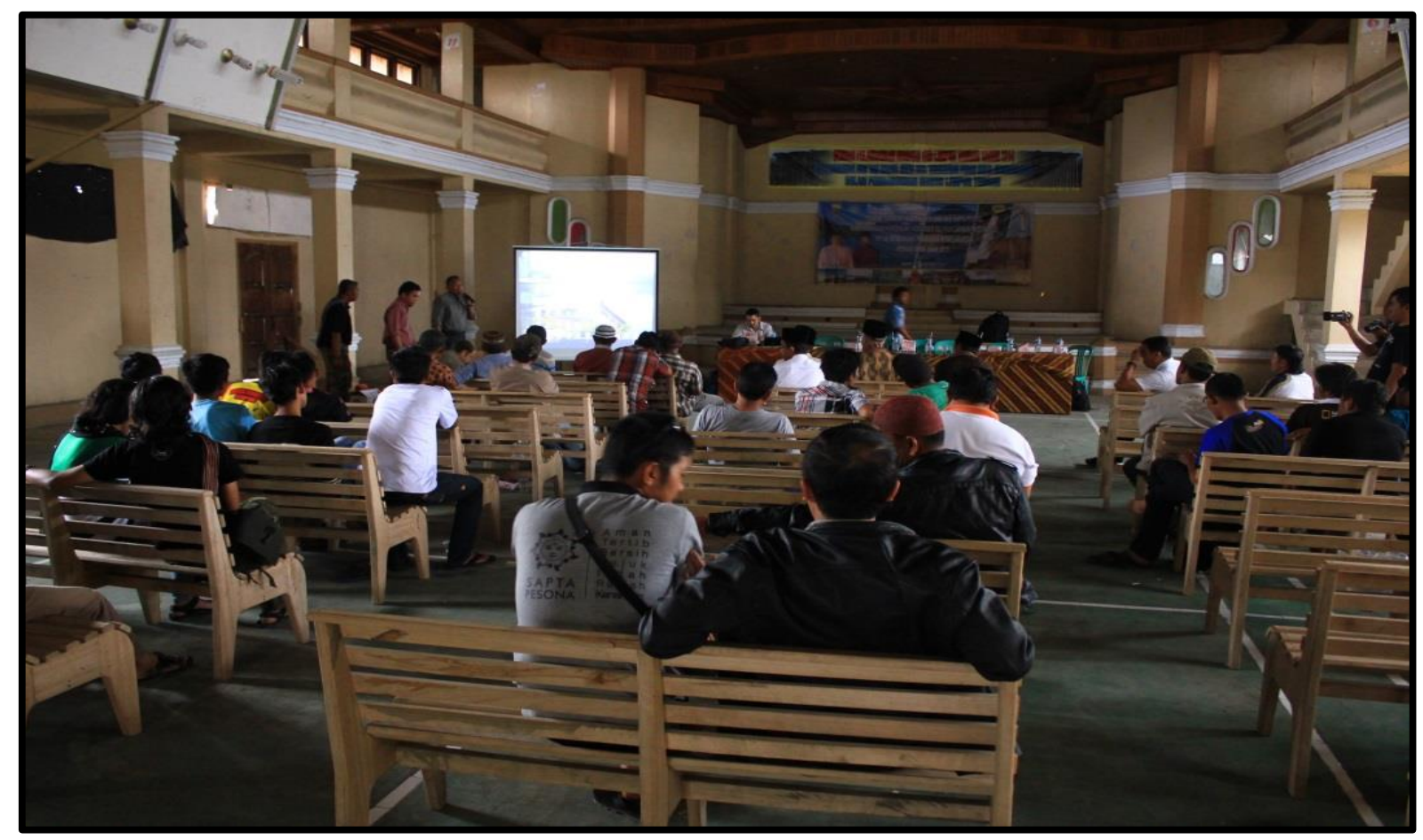

Source: Author's Photo

Picture 2 An informal meeting in Lempur Tengah Village

\subsubsection{Focus group discusion}

Focus group research is one of the most common research methods to collect information in the form of a group interview that capitalizes through communication among study participants to generate data (Kitzinger, 1995; Bickman, 1998). By involving 8 to 12, group disccusion discusses about specific topics under the direction of a professional moderator, which emphasizes interaction and ensure that the discussion stays on topic of interest. FGD normally lasts for 1.5 to 2.5 hours. Most general purpose of the focus group interview is to stimulate in-depth exploration of a topic about which little is known, identifying similarities and differences so that qualitative focus group research may be useful for the current exploration rather little is known about the phenomenon of interest. As a result, focus groups tend to be used very early in the research project (Bickman, 1998).

Method focus group is also used to examine not only what people think but also how they think, why they think that way, because it is useful to explore the knowledge and experience of the people. This method is used as a quick and easy way to collect data from multiple people simultaneously so everyone can copy it to ask, talk, ask questions and exchange ideas also experience even swapped anecdotes (Kitzinger, 1995). 
Related research focus groups, the first group discussion conducted at the workshop forum of State Forest Enterprise (Perhutani) at $29^{\text {th }}$ July 2013 in Semarang. This meeting was adviced from the manager of KSNP to get information about the management and access restrictions on the existence of protected areas. In this forum, researcher was asked to be a single speaker and also used by researcher to conduct group discussions related to this study. Actually, there is one more group discussion suggested, namely meetings at the national level held by the Ministry of Forestry, but because of the time and place that was not manageable, the researcher decided to cancel the meeting. Second, Group Discussion organized by researcher inviting head of some villages where is part of Kayu Aro, Kayu Aro Barat and Gunung Tujuh Sub-districts. The second group discussion was more emphasing on the participation and sharing knowledge and experiences among local communities in their relations with the KSNP manager and their interaction with other users. The third FGD was done at the KSNP authority office. The third meeting aimed on the role of manager in the management, preservation and preventing damage of KSNP as well as interaction with other stakeholders.

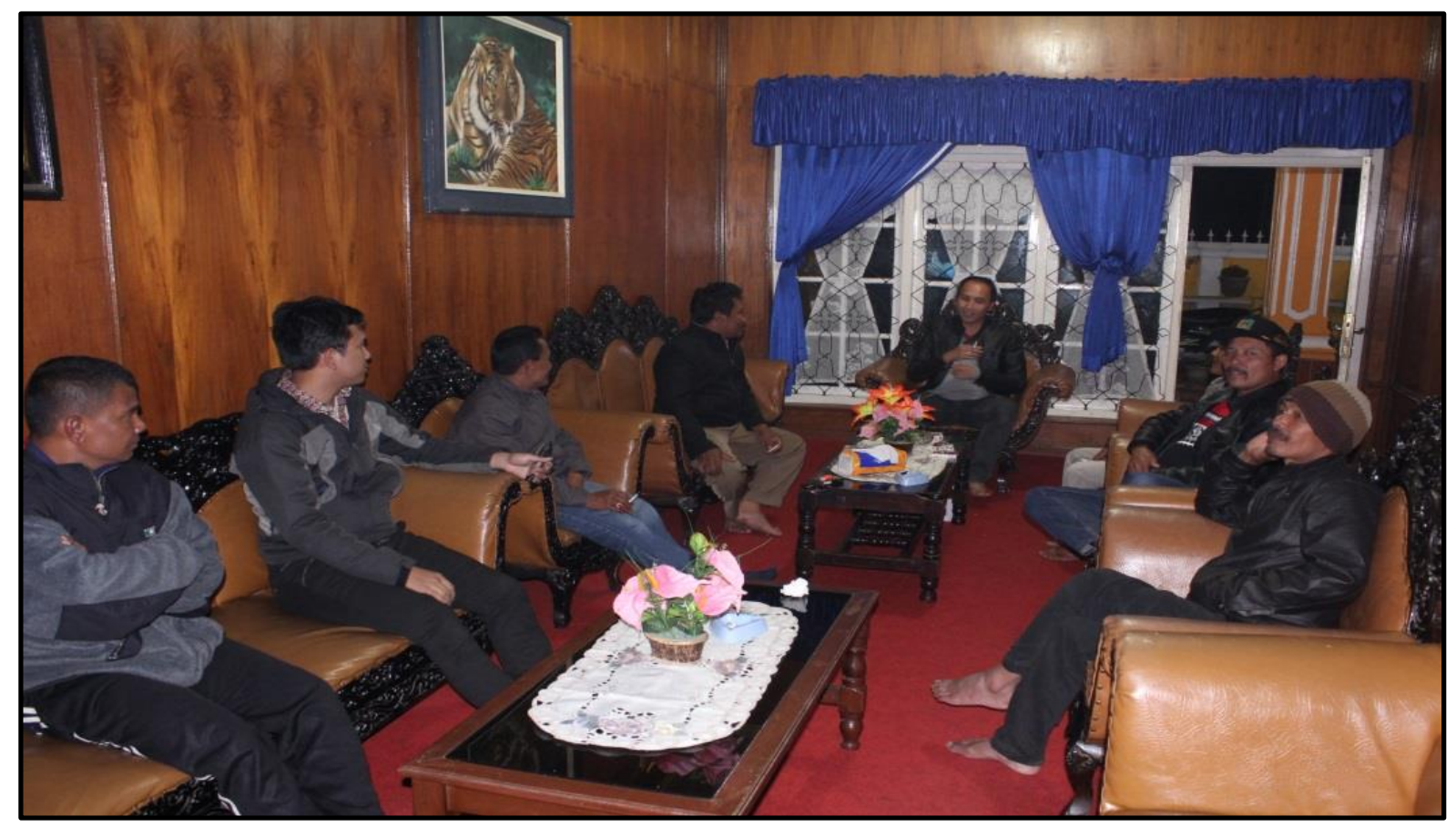

Source: Author's Photo

Picture 3 Focus group discussion with local communities located in Lindung Jaya village 


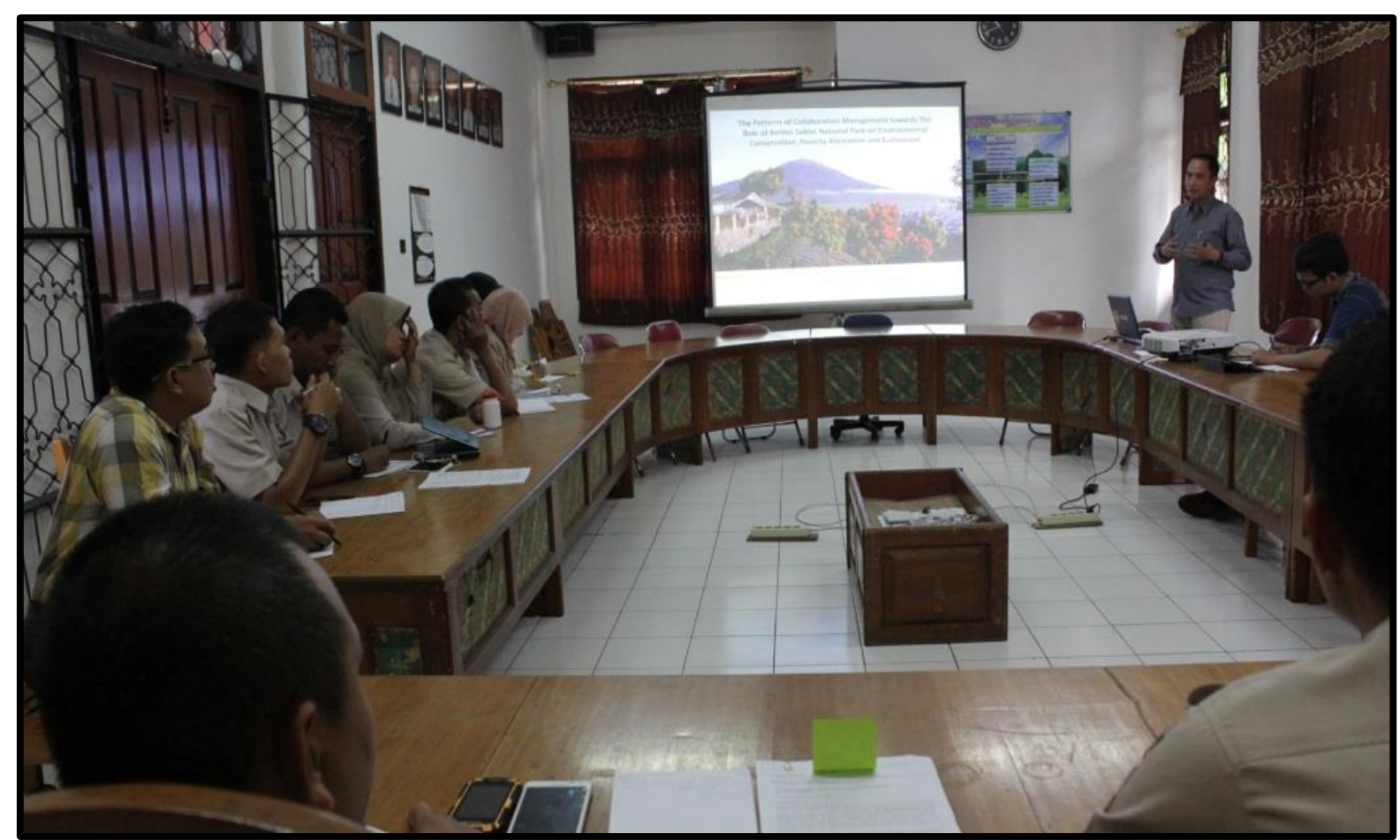

Source: Author's Photo

Picture 4 Focus group discussion with the KSNP office staffs

\subsubsection{Informal interview}

Interview is a way to conduct data collection in the field. Some common types of interviews are conducted as a structured interview, semistructur, informal and retrospective. Structured and semi-structured interviews with the aim to find perspective by society itself is a kind of formal interviews. On the other hand, there is also a kind of informal interviews. The opposite of an explicit formal interview with the objective, informal interviews have specific research agenda but it is implicit. Researchers have its own approach techniques to obtain the desired achievement (Leonard \& Rog, 1998).

The most challenging job when doing informal interviews was when approached local people in places where they usually congregate such as coffee shops, food stalls, the rest of the field or fields and in public places where they usually gather. Challenging because when approached respondents course they will recognize us as outsiders, and this requires a technical approach that is not easy because if the wrong approach to the information to be acquired may not be successful. Another thing is when conducting interviews the number of participants will increase over the length of time required. 


\subsubsection{Collecting secondary data}

The literature review was not only conducted in the beginning of the study, but was maintained throughout the research, especially in an effort to fully understand and review indepth documents. Such documents include those focused on geographic location, land area and productivity, population size, social aspects, demographics, economic data such as livelihood, and main commodities. The data is labeled as the Village Potential Data (Data Potensi Desa), Forestry and Agriculture Potential Data (Data Potensi Kehutanan dan Perkebunan), Survey Data, Report of Regent Accountability, and long-term and short-term strategies. Moreover, an in-depth review of the documents was completed in order to accumulate information regarding social, economic and political conditions, as well as to provide a comparison between previous studies and real conditions.

Furthermore, secondary data also includes relevant information from both the territory of Kerinci Seblat National Park (KSNP) and Kerinci Regency. The related documents are the Statistics of Forestry and Agriculture of Kerinci Regency in 2011 and 2012, Planning of MidTerm Local Development from 2009 to 2014, various decrees to the Regional Head in regards to KSNP, the traditional village, the recognition of customary rights, Planning of mid-Term Investment, the Spatial Region Plan for 2012-2032, Statistic Bereau of Kerinci Regency in 2013 and 2014, Statistical of Kayu Aro Sub-district, Gunung Raya Sub-district, Danau Kerinci Sub-district, and Gunung Tujuh Sub-district in 2013.

Secondary data was collected during observation and field survey. The secondary data cover geography such as map of the region, demography like social and economy conditions, legal and policy in local and national level in regards to management of forest and protected area, and the programs of collaboration. The main data was provided by the office of Forestry and Agriculture (plantation) and the office of KSNP. The other secondary data was supported by Directorate General of Service and Environment.

\subsection{Analysis data}

This step includes the complete analysis of the research, with results being based on primary and secondary data. The primary data were collected during the observation and field work stages of this research. Primary data include data obtained from interviews with key respondents, using the snowball technique. Furthermore, the primary data were collected from experts, academic scholars, local communities, regional office staff members and leaders, 
NGO activists, tourists, business people and the KSNP managers. Secondary data are collected from a variety of academic literature sources such as journals, dissertations and other forms of research reports. In addition to academic sources, secondary data were also collected from information provided by online sources, as well as mass media such as magazines, newspapers and various books discussing the topic of this study.

The data were further analyzed through the qualitative-descriptive approach which consists of classifying, reducing, validating and interpreting the data according to the research objectives (Berg, 2007; Strauss \& Corbin, 1998; Adiwibowo, Shobudddin, Savitri, Syaf, \& Yusuf, 2008). In summary, the current research approach used an analysis of the literature, content analysis, document trace, case studies and a study of history, as well as in-depth interviews with key respondents. The objective of the literature analysis was to comprehensively and comparatively obtain information related to the patterns of collaborative management within KSNP. Furthermore, the literature analysis includes information related to previous studies done at KSNP and in Kerinci Regency, as well as in other regions of Indonesia and other countries. The content analysis was conducted to attain an in-depth analysis of national government policy, local government policy and the KSNP management.

\subsubsection{Qualitative content analysis}

Content Analysis is a qualitative research technique that are widely used (Hsieh \& Shannon, 2005; Elo \& Kynga“s, 2007; Berg, 2007). The advantages of content analysis can be used to analyze quantitative and qualitative data (Elo \& Kynga's, 2007). In addition, Content analysis is also a method that can describe the phenomenon objectively and systematic (Sandelowski, 1995; Elo \& Kynga“s, 2007). This method is also a method often used to analyze the documents. It is possible also examined the deeper understanding of the data and in the process of filtering data for categorization will be shorter (Elo \& Kynga“s, 2007). Content analysis also allows data to photograph, videotape, and many others can be made to the text (Berg, 2007). This method was used to analyse documents related to regulation, any kind of laws, and policy documents.

\subsubsection{Institutional analysis and development network}

Institutional analysis and development (IAD) is regarded as appropriate analytical approach to the management of natural based resource and collaboration (Imperial, 1999; 
(Klain, Beveridg, \& Bennett, 2014). With this analysis approach, this study has decided that all of the stakeholders involved in an administrative body of management of natural resources (rainforest) in the same position as a participant in an arena (Mehring, et al., 2011; Ostrom, 2011). There are at least four useful attributes associated with its use in the management of natural resources; (1) this analysis recognizes a number of transaction costs related to the implementation of the policy, (2) the analysis gives attention to the contextual conditions such as culture, land, biology and socioeconomic believed to affect the performance and institutional design, (3) this analysis does not provide conditions of bias normative to responsibility of implementing the program, (4) it is not also to give a prescribe that it would be better centralized control of decentralized arrangements, (5) more focus on regulations rather than extending the policy related to organizational relationships (Imperial, 1999).

\subsubsection{Interpretative - qualitative analysis}

There are three types of qualitative analysis, they are interpretative, social anthropology, and collaborative social research. By using interpretative approach allows the analysis of social action and community activities articulated in the text. This approach provides a way to find meaning and purposing of the activity. Thus, the data will be organized or decreased based on the interpretation of the researcher. Human actions can be seen as an act of symbols expressing layers of understanding (Berg, 2007). 


\section{Chapter IV. Research Area and Geographic Characteristics}

\subsection{Why has Kerinci Seblat National Park been selected as a research area?}

\subsubsection{Location and the area of Kerinci Seblat National Park}

Kerinci Seblat National Park (KSNP) with an area of $13,791 \mathrm{~km} 2$ is located between $100^{\circ} 31^{\prime} 18^{\prime \prime}-102^{\circ} 44^{\prime}$ East and 17'13" - 326'14" South. KSNP is the largest protected forest zone of primary forest in Sumatra, Indonesia. The park has a length of about $345 \mathrm{~km}$, which extends along the Barisan Mountain range that crosses Sumatra along the southwestern side of the island. Based on physiography, The park is divided into four regions beginning with the coastal area, then the high area with an average altitude of 2,000 $\mathrm{m}$ above sea level and including a series of volcanos, Mount Kerinci (3.804 m), Lake Gunung Tujuh (2,300 ml) with its lake Gunung Tujuh, and Mount Masurai in the southern valley. The physiologies of KSNP are further categorized as follows: a narrow beach in the West; the Barisan Mountains which extends from the West to the Southeast Sea and includes nine peaks, with the highest peak reaching 2,400 m; the valley in the central area that extends parallel to the Barisan Mountains; and the foothills (Khalik, 2007; Adiprasetyo, 2010; Government of Kerinci Regency, 2012). Map 3 shows the trajectory chain of the Barisan Mountains in relation to KSNP.

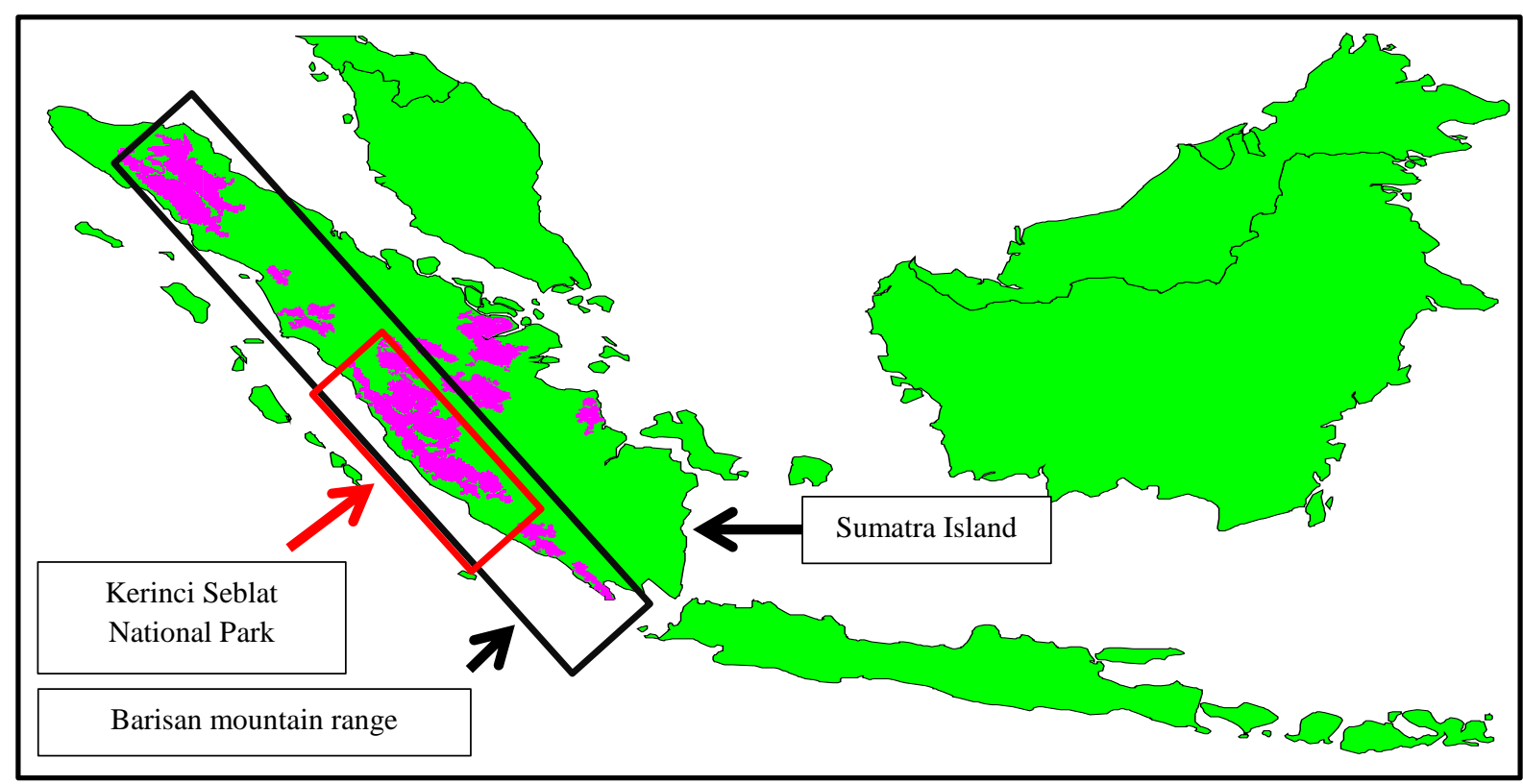

Source: Fauna \& Flora International, 2014

Map 3 Barisan mountain range, Sumatra 
KSNP is the largest national park in Sumatra, Indonesia and the third largest conservation area in the Indonesian archipelago which spans four provinces: West Sumatra 353,780 ha (25\%), Jambi 422,190 ha (40\%), Bengkulu 310,910 ha (21\%) and South Sumatra 281,120 ha (14\%). Table 12 shows the extent of KSNP according to specific provinces and regencies. KSNP is spread across 9 regencies, 4 provinces, 43 districts, and 134 villages, with Jambi province and Kerinci Regency covering the largest share of KSNP (Frankistoro, 2006; Khalik, 2007; the KSNP authority, 2014).

Table 12 The coverage area of Kerinci Seblat National Park

\begin{tabular}{|c|c|c|c|c|}
\hline & Provinces & Regencies & Area (Ha) & $\begin{array}{l}\text { Percentage } \\
\text { of area to } \\
\text { total area }\end{array}$ \\
\hline \multirow{3}{*}{1} & \multirow{3}{*}{ Jambi } & Kerinci & $215,000.00$ & \multirow{3}{*}{32.4} \\
\hline & & Bungo & $86,363.00$ & \\
\hline & & Merangin & $148,833.00$ & \\
\hline \multicolumn{3}{|c|}{ Sub Total } & $450,196.77$ & \\
\hline \multirow{3}{*}{2} & \multirow{3}{*}{ West Sumatra } & Solok and Solok Selatan & $81,196.00$ & \multirow{4}{*}{25.05} \\
\hline & & Dhamasraya & $5,992.52$ & \\
\hline & & Pesisir Selatan & $260,967.58$ & \\
\hline \multicolumn{3}{|c|}{ Sub Total } & $348,125.10$ & \\
\hline \multirow{2}{*}{3} & \multirow{2}{*}{ Bengkulu } & $\begin{array}{l}\text { Bengkulu Utara and } \\
\text { Muko-Muko }\end{array}$ & $188,474.00$ & \multirow{2}{*}{24.51} \\
\hline & & $\begin{array}{l}\text { Rejang Lebong and } \\
\text { Lebong }\end{array}$ & $152,101.00$ & \\
\hline \multicolumn{3}{|c|}{ Sub Total } & $340,575.00$ & \\
\hline \multirow{2}{*}{4} & \multirow{2}{*}{ South Sumatra } & Musi Rawas & $243,997.00$ & \multirow{2}{*}{18.04} \\
\hline & & Lubuk Linggau & $6,616.00$ & \\
\hline & \multicolumn{2}{|c|}{ Sub Total } & $250,613.00$ & \\
\hline & \multicolumn{2}{|r|}{ Total } & $1,389,549.87$ & \\
\hline
\end{tabular}

Source: Ministry of Forestry of Indonesia, 2010

Kerinci Seblat National Park is the integration of protected areas including the Inderapura and Bukit Tapan sanctuaries, Rawasa Huku Lakitan, Bukit Kayu Embun, and Gedang Seblat wildlife preservation areas, the surrounding protected forests, as well as Hutan 
Produksi Terbatas which functions as a hydro-orologis and is vital to the area. The protected forest groups serve as the major water sheds for some main rivers the surrounding area and Jambi province, namely Batanghari, Musi and the Western Coastal Area Water Sheds. The water sheds have a vital role in fulfilling water needs for millions of people living surrounding areas. Tabel 13 shows the name of rivers in each province in detail.

Table 13 The name of rivers (water shed) in each provinces surrounding KSNP

\begin{tabular}{|c|c|c|c|}
\hline No & Provincies & Name of watersheed & $\overline{\text { Area }(\mathrm{Ha})}$ \\
\hline \multirow{2}{*}{1} & \multirow{2}{*}{ West Sumatra } & Sangir & \multirow{2}{*}{287} \\
\hline & & Indrapura & \\
\hline 2 & Jambi & Batang Hari & $4,910,000$ \\
\hline \multirow{3}{*}{3} & \multirow{3}{*}{ South Sumatra } & Musi & \multirow{3}{*}{$3,950,000$} \\
\hline & & Tialang & \\
\hline & & Lakitan & \\
\hline \multirow{5}{*}{4} & \multirow{5}{*}{ Bengkulu } & Manjuto & \multirow{5}{*}{793,000} \\
\hline & & Ketauan & \\
\hline & & Ipuh & \\
\hline & & Seblat & \\
\hline & & Diklat & \\
\hline
\end{tabular}

Source: Frankistoro, 2006

Tabel 13 according to (Kasih, 2012), in 1926 the Dutch colonial government established the forest in the central part of the area as a protected forest, this forest was referred to as Bosswesen (BW) by local people. For several decades, the forest area that stretches along the Barisan Mountain range was defined as an area of status and with specific designation by the respective provincial governments. In consideration of the vital role of the forest groups, The World National Park Congress in Bali designated the region as Kerinci Seblat National Park on October $4^{\text {th }} 1982$. KSNP consists of lowlands, as well as mountains and has an altitude ranging between 200 and 3,805 $\mathrm{m}$ above sea level. There are three slope classes in the park, as shown Table 14, generally, the topography of the area is rigid, sharply sloping and rolling. The slope of the land within KSNP area various from $0-3$ percent to $>40$ percent. However, the land is largely dominated by slopes above 40 percent. The slopes are a physical aspect that act to maintain the stability of the land. The greater the slope level, the greater the occurrence of land instability; for example, landslides (Frankistoro, 2006). Relatively flat topography is also found in KSNP, specifically in Kerinci Regency (enclave). 
Table 14 The detail area of Kerinci Regency based on altitude above sea (in ha)

\begin{tabular}{|l|l|c|c|c|c|}
\hline \multirow{2}{*}{ No } & \multirow{2}{*}{ Sub-districts } & \multicolumn{3}{|c|}{ Altitudet (meter asl) } & \multirow{2}{*}{ Total } \\
\cline { 3 - 5 } & & $100-500$ & $500-1000$ & $<1000$ & \\
\hline 1 & Kayu Aro & & & 49.055 & 49.055 \\
\hline 2 & Gunung Tujuh & & & & \\
\hline 3 & Gunung Kerinci & - & 4,025 & 89.955 & 94,020 \\
\hline 4 & Siulak & & & & \\
\hline 5 & Air Hangat & & 4,160 & 36.095 & 40.255 \\
\hline 6 & Air Hangat Timur & & & & \\
\hline 7 & Depati VII & & & & 5.825 \\
\hline 8 & Sitinjau Laut & - & 4,310 & 25.42 & 29.73 \\
\hline 9 & Danau Kerinci & - & 4,490 & 25,830 & 30,320 \\
\hline 10 & Keliling Danau & - & 21,562 & 30,302 & 56,510 \\
\hline 11 & Batang Merangin & 4,646 & 22,945 & 49,450 & 74,385 \\
\hline 12 & Gunung Raya & 1,990 & 61,492 & 311,972 & 380,100 \\
\hline Total & & 6,636 & 16,18 & 82,08 & 100,00 \\
\hline Percentage & 1,75 & & & \\
\hline
\end{tabular}

Source: Government of Kerinci Regency, 2009

The topography of the Kerinci Regency is located at an altitude of $500 \mathrm{~m}-3,805 \mathrm{~m}$ above sea level, has a tropical climate and cold air, with an average temperature of 22 degrees Celsius. Of the 12 sub-districts located in Kerinci Regency, the majority (81.22\%) have an altitude of above $1,000 \mathrm{~m}$, while the rest of the area is below 1,000 m. Moreover, two Subdistricts, namely Gunung Raya and Batang Merangin, are located below $500 \mathrm{~m}$ and are comprised of a total area of 6,636 ha $(1.58 \%)$. Table 15 presents the complete data regarding (Government of Kerinci Regency, 2009), based on districts and altitude. 
Table 15 Forest cover and the changes in the Regions around KSNP

\begin{tabular}{|c|l|c|c|c|c|c|}
\hline \multirow{2}{*}{ No } & \multirow{2}{*}{ Regions } & \multicolumn{4}{|c|}{ Forest cover (ha) } & \multicolumn{2}{c|}{ Changes in forest cover } \\
\cline { 3 - 7 } & & $\mathbf{1 9 8 5}$ & $\mathbf{1 9 9 5}$ & $\mathbf{2 0 0 2}$ & $\mathbf{1 9 8 5} / \mathbf{1 9 9 5}$ & $\mathbf{1 9 9 5 / 2 0 0 2}$ \\
\hline \multirow{2}{*}{1} & \multirow{2}{*}{$\begin{array}{l}\text { Bengkulu } \\
\text { Utara }\end{array}$} & 430,010 & 532,530 & 333,126 & -18.0 & -5.5 \\
\hline 2 & Bungo & 131,269 & 133,016 & 120,309 & 1.3 & -9.6 \\
\hline 3 & Kerinci & 221,649 & 220,274 & 212,689 & -0.6 & -3.4 \\
\hline 4 & Merangin & 312,080 & 309,808 & 289,324 & -0.7 & -6.6 \\
\hline 5 & Musi Rawas & 296,749 & 287,576 & 281,597 & -3.1 & -2.1 \\
\hline 6 & Pesisir Selatan & 325,865 & 328,477 & 314,594 & 0.8 & -4.2 \\
\hline 7 & Rejang Lebong & 149,162 & 141,384 & 130,762 & -5.2 & -7.5 \\
\hline 8 & Sawah Lunto & 56,986 & 43,569 & 35,885 & -23.5 & -17.6 \\
\hline 9 & Solok & 432,639 & 427,612 & 395,812 & -1.2 & -7.4 \\
\hline Total & $2,356,410$ & $2,244,246$ & $2,114,101$ & -4.8 & -5.8 & \\
\hline
\end{tabular}

Source: Adiprasetyo, 2010

Referring to data from the Government of Kerinci Regency (2012) with regards to morphology, Kerinci Regency can be classified as having a plane morphology, with smooth rolling hills, hilly areas, and mountainous areas. Therefore, it can be seen that distribution of the rock toward the north ranges from rolling hills to mountainous and has varying rock types, whereas the morphology in the South is dominated lowland topography and has relatively similar rock types. The existing topography and morphology conditions leads to the KSNP area located in the surrounding of Kerinci Regency to have extensive resources, as well as fascinating natural beauty. However, utilization of the forest in the area around and inside KSNP has resulted in changes in land cover. These changes are estimated to be relatively small when compared to those in the area that is not designated as KSNP. The changes in forest cover inside and outside KSNP is presented in Table 15 above.

\subsubsection{Ecobiological environment}

KSNP represents several ecosystem types: lowland rainforest, sub-alpine zone, petswamp, fresh water swamps and lakes. The great diversity of forest types represented in 
KSNP is related to the substantial variation in altitude in this region (300-3,800 m). Lowland forest $(<300 \mathrm{~m})$ is the only forest type not represented within the park. There are approximately 400 species of plants of many different varieties, such as trees, shrubs and lianas. KSNP trees are typical plants with high-value timber, such as wood torch, Kerinci pine and raflesia. There are also several types of endemic wildlife, such as Sumatran tigers, Sumatran rhinoceros and Sumatran elephants (The KSNP authority, 2014).

Apart from the biological diversity of plants and animals, the enactment of the Kerinci Seblat forest as a nature conservation area is also due to its hydrological functions. The watersheds of the Batang Hari, Indrapura, Musi, Rawas and other rivers are important water catchment areas. These three factors, namely plant diversity, animal diversity and hydrological functions, are expected to provide protection and breeding opportunities for various species of plants, animals and ecosystems. Table 16 below describes the types of forests and vegetation found in KSNP.

Table 16 The forest types and vegetations

\begin{tabular}{|c|c|c|}
\hline & Forest types & Vegetations \\
\hline 1 & Mid montane forest & $\begin{array}{l}\text { - Located at an altitude of } 1900-2400 \text { meters above sea } \\
\text { level, the proportion of microphyllus plants relatively a lot } \\
\text { and the forest canopy becomes less great. } \\
\text { - Podocarpus is a prominent species that can reach a height } \\
\text { of } 25 \text { meters and the species with a canopy height of 15-20 } \\
\text { meters include; Quercus oidcarva, Vemonia arborea, } \\
\text { Amodia puncata, Symingt onia populnea, Drypetes } \\
\text { subsymetrica, Gordonia buxifolia, Weinmania blumet and } \\
\text { Polysma integrifolia. } \\
\text { - Lower canopy species are characterized by Olea javanica, } \\
\text { Archidendron clypearia, Platea excelsa, Lithocarpus } \\
\text { pseudomoluccus and Myrsine hasseltii }\end{array}$ \\
\hline 2 & $\begin{array}{l}\text { Upper-montane } \\
\text { forest }\end{array}$ & $\begin{array}{l}\text { - Dominant genus are Symplocos, Myrsine and Ardisia } \\
\text { located at an altitude between } 2400-2900 \mathrm{~m} \text { asl } \\
\text { - The main species in the highest canopy (10-15) are } \\
\text { Symplocos cochinchinensis var, and Ilex Sessilifolia } \\
\text { pletobrachiata, while the lower layer is dominated by }\end{array}$ \\
\hline
\end{tabular}




\begin{tabular}{|c|c|c|}
\hline & & $\begin{array}{l}\text { Arsdisia leavigata, Meliosma lanceolata and Cyathea } \\
\text { trahypod }\end{array}$ \\
\hline 3 & Sub alpine thicket & $\begin{array}{l}\text { - At an altitude of } 2900 \mathrm{~m} \text { to above, we find a sub-alpine } \\
\text { meadow with a height of 3-6 m dominated by Ericaceae } \\
\text { (Rhododendron retusum, Vacinum miquelii and } \\
\text { Gaultherianummlaroids), and Symplocaceae (Symplocos } \\
\text { cohinchinensis) }\end{array}$ \\
\hline 4 & $\begin{array}{l}\text { Some wetlands found } \\
\text { in KSNP }\end{array}$ & $\begin{array}{l}\text { - The example is Bento Swamp, which lies at an altitude of } \\
\text { 1,375 meters above sea level, a wetland with an area of } \\
\text { about 1:00 ha which consists of swamp forest with tiny } \\
\text { plants, peat bogs and small lakes, comprising trees with a } \\
\text { height of 5-6 m in diameter which varies between } 2-6 \mathrm{~cm} \\
\text { (Giessen and Sukotjo, 1991) }\end{array}$ \\
\hline
\end{tabular}

Source: Kasih, 2012

Rare and endemic plant species live in KSNP and are estimated to be around 4,000 species, including 300 species of orchids, Kerinci pine (Pinus merkusii strain Kerinci), sweety wood (Harpilus arbarea), tubes (Histiopteris incisca), carrion flowers (Amorphophalus titanium), Raflesia flower (Raflesia Arnoldi). Furthermore, according to research reports from the Biological Science Club (BSCC) in 1993, KSNP has 115 species of medicinal plants (Kasih, 2012). Table 17 describes the types of plants (flora) that are protected in the KSNP area of Kerinci Regency under the Government Regulation No.7 of 1999.

Table 17 Types of plants protected in the KSNP area

\begin{tabular}{|l|l|l|}
\hline \multirow{4}{*}{ No (Name) } & \multicolumn{1}{|c|}{$\begin{array}{c}\text { The Plant types } \\
\text { (Scientific Names) }\end{array}$} & \multicolumn{1}{c|}{$\begin{array}{c}\text { Plant types } \\
\text { (Indonesian Names) }\end{array}$} \\
\hline \multirow{4}{*}{1 (Palmae) } & Amorphopallus decussivae & bunga bangkai jangkung \\
\cline { 2 - 3 } & Amorphopallus titanium & bunga bangkai raksasa \\
\cline { 2 - 3 } & Borrassodendron borneensis & bindang, budang \\
\cline { 2 - 3 } & Cryota no & palm raja \\
\cline { 2 - 3 } & Eugeissona utilis & bertan \\
\cline { 2 - 3 } & Johanneste ijsmaria altifrons & daun payung \\
\cline { 2 - 3 } & Livistona spp & palem kipas Sumatra \\
\hline
\end{tabular}




\begin{tabular}{|c|c|c|}
\hline & Nenga gajah & palem Sumatra \\
\hline & Phoenix paludosa & korma rawa \\
\hline & Pigafatta filaris & manga \\
\hline 2 (Rafflesiacea) & Rafflesia arnoldi & raflesia \\
\hline 3 (Dipterocarpaceae) & Shorea spp & tengkawang \\
\hline \multirow{7}{*}{4 (Orchidaceae) } & Coelogyne pandurata & anggrek hitam \\
\hline & Dendrobium $\mathrm{sp}$ & anggrek \\
\hline & Macodes sp & anggrek ki aksara \\
\hline & Paphiopedilum praestans & anggrek kasut pita \\
\hline & Paraphalaenopsis denevei & anggrek bulan bintang \\
\hline & Phalaenopsis sumatrana & anggrek bulan Sumatra \\
\hline & Phalaenopsis violacose & anggrek kelip \\
\hline \multirow{6}{*}{5 (Nephentaceae) } & Nepenthes aristolochiodes & kantong semar \\
\hline & Nepenthes gracilis Korth & kantong semar \\
\hline & Nepenthes mirabilisDruce & kantong semar \\
\hline & $\begin{array}{l}\text { Nepenthes reinwardtiana } \\
\text { Miq }\end{array}$ & kantong semar \\
\hline & Nepenthes rafflesiana Jack & kantong semar \\
\hline & Nepenthes singgalanga & kantong semar \\
\hline
\end{tabular}

Source: Statistics of Kerinci Regency, 2013

In addition to the endemic and unique plant types, KSNP has endemic, flagship and endangered wildlife species such as the Sumatran tiger (Panthera tigris sumatrae), Sumatran rhinoceros (Dicerorhinus sumatrensis), Sumatran elephant (Elephas maximus sumatranus), gibbon (Sympalangus syndatylus) and tapir (Tapirus indicus). For a complete list of all endangered species in KSNP, see Table 18.

KSNP also has a wide variety of endangered and unique species of birds such as Nipon kestrel eagles (Accipter gularis), crested hornbill (Aceros comatus), argus (Argusianus argus), pheasant chicken (Lophura inornata), rhinoceros hornbill (Buceros rhinoceros), hornbill (Anthrococeros), black hawk (Ictinaetus malayensis), Sumatran cochoa (Cochoa beccarii), large-headed pitta (Pitta schineideri), Sumatra peacock (Polypectron chalcurum), along with 352 other bird species. The assets of natural resources, as well as various types of plants and 
rare animals living in KSNP make the conservation area appropriate for convening the Integrated Conservation and Development Program (ICDP) project.

Table 18 Protected animals in the KSNP area of Kerinci Regency

\begin{tabular}{|c|c|c|}
\hline No & $\begin{array}{c}\text { The types of animals } \\
\text { (Scientific names) }\end{array}$ & $\begin{array}{l}\text { The types of animals } \\
\text { (Indonesian names) }\end{array}$ \\
\hline 1 & Articitis binturong & binturung \\
\hline 2 & Arctonyx collaris & pulusan \\
\hline 3 & Capricornis sumatrensis & kambing Sumatra \\
\hline 4 & Cervus spp. & menjangan, rusa, sambar \\
\hline 5 & Cynocephalus variegatus & kubung, tando, walangkekes \\
\hline 6 & Catopuma teminninckii & kucing emas \\
\hline 7 & Diceorhinus sumatrensis & badak Sumatra \\
\hline 8 & Elephas maximus & gajah \\
\hline 9 & Felis viverrinus & kucing bakau \\
\hline 10 & Lariscus insignis & bajing tanah, tupai tanah \\
\hline 11 & Hylobates syndactylus & siamang \\
\hline 12 & Hylobates agilis & ungko \\
\hline 13 & Helarctos malayanus & beruang madu \\
\hline 14 & Hystrix brachyuran & landak \\
\hline 15 & Manis javanica & trenggiling, peusing \\
\hline 16 & Muntiacus muntjak & kijang, muncak \\
\hline 17 & Mydaus javanensis & sigung \\
\hline 18 & Neofelis nebulusa & harimau dahan \\
\hline 19 & Nesolagus netsheri & kelinci Sumatra \\
\hline 20 & Nycticebus coucang & malu - malu \\
\hline 21 & Panthera tigiris sumatrae & harimau Sumatra \\
\hline 22 & Pardofelis eiegans & cukbo, bajing terbang \\
\hline 23 & Prionodon linsang & musang congkok \\
\hline 24 & Ratufa bicolor & jelarang \\
\hline 25 & Tapirus indicus & tapir, cipan, tenuk \\
\hline
\end{tabular}




\begin{tabular}{|c|l|l|}
\hline 26 & Tarsius bancanus & binatang hantu, singapuar \\
\hline 27 & Tragulus napu & napu, tapir \\
\hline 28 & Tragulus javanicus & kancil, pelanduk \\
\hline
\end{tabular}

Source: Statistics of Kerinci Regency, 2013

\subsubsection{Management of Kerinci Seblat National Park}

Based on the Decree of the Minister of Agriculture number 736/MENTAN/-X/1982, it was determined that the area of KSNP was composed of 1,484,650 hectares, with 588,460 ha $(40 \%)$ in Jambi, 375,930 ha $(25 \%)$ in West Sumatra, 340,580 ha $(21 \%)$ in Bengkulu, and 209,680 ha (14\%) in South Sumatra (The KSNP authority, 2014). The defined land areas were then changed in accordance with the restructuring undertaken by the Ministry of Forestry in 1996. Based on the Forestry Ministerial Decree number 192 / Kpts-11/1996 dated May 1, 1996, the land area became 1,368,000 ha, with 422, 192 ha (30.36\%) in Jambi, 355,780 ha $(25.86 \%)$ in West Sumatra, 310, 910 ha (22.73\%) in Bengkulu and 281,120 ha (20.25\%) in South Sumatra (Supriatna, 2013). Based on this categorization of land area, Jambi province contains the largest area of the national park, while Pesisir Selatan Regency in Western Sumatra province has the greatest national park area (see Table 2). In terms of organizational efforts KSNP is managed as part of the national park with the duties and functions of the management team following the Minister of Forestry Decree No. 68/1998 on the organization and working procedures of the national park agency (Adiprasetyo, 2010), as follows:

1) Develop plans, programs and conduct evaluation of the national park management

2) Preservation and sustainable use of national parks

3) Protection, security and fire prevention of the area

4) Promotion, information, development of tourism and the local communities love of nature, as well as the extension of conservation of natural resources and the ecosystem

5) Collaboration in national park management

6) Implementation of administrative and household affairs

Furthermore, based on this ministerial decree, management attempts to mitigate problems related to the following objectives:

1) The development of institutions, professionalism and management efficiency

2) The management of conservation areas 
3) The management of biodiversity conservation

4) Forest protection and safeguarding

5) The development of natural tourism

6) The control of forest fires

7) Extension, information and promotion

8) The development of buffer zones and economic empowerment

9) The development of partnership and networking

The KSNP management status changed on February 1, 2007 with the issuance of the Minister of Forestry Regulation No. P.03 in 2007, KSNP as a Technical Unit has responsibilities such as:

1) Zone structuring, preparation of action plans and monitoring, as well as evaluation of the national park's management efforts

2) Management of the national park

3) Query, protection and security of the national park

4) The control of forest fires

5) Promotion and information on the conservation of natural resources and ecosystems

6) Development of nature lover group and extension of the efforts for conservation of natural resources and ecosystems

7) Collaboration in the development of the conservation of natural resources and ecosystems, along with partnerships

8) Empowerment of the community surrounding the national park

9) The development and use of environmental services and natural tourism

10) The implementation of administrative and household affairs

The consequences of the implementation of the new Minister of Forestry Regulation are primarily the changes in the organizational structure and function of the KSNP management team. Based on the new organizational structure, the director of the KSNP authority, located in the city of Sungai Penuh (the capital city of Kerinci Regency), is assisted by the Head of Administration with three sub-division, as well as by the four divisions responsible for its working area. The Technical Division of Conservation at Kerinci Seblat National Park has the following functions and duties: (1) protection and security of the area and law establishment and enforcement, (2) preservation of wild plants and animals, (3) development of the utilization of environmental services and natural tourism, (4) counseling, development of the 
cooperative body and community empowerment. The management of KSNP is based on zoning is used as the basis for management covers, with the main zone having an area of 744,990 ha, the forest zone with 463,394 , the utilization zone at 17,802 ha, the rehabilitation zone having 136,791 ha, the special zone with 13,789 ha and the traditional zone with12,733 ha (The KSNP authority, 2014).

\subsection{Geographic characteristics of Kerinci Regency}

\subsubsection{Administrative location}

Kerinci Regency is located at a unique geographical position as it is surrounded by a conservation area, Kerinci Seblat National Park, although it is situated at the western end of the Jambi province. Referring to the data issued by the local government, Kerinci Regency is located at the coordinates between $101^{\circ} 08^{\prime} 00^{\prime \prime}$ and $101^{\circ} 50^{\prime} 00^{\prime \prime}$ longitude and between $1^{\circ}$ $40^{\prime} 00^{\prime \prime}$ and $2^{\circ} 26^{\prime} 00^{\prime \prime}$ latitude. Kerinci Regency has an area of 380,850 hectares or 3,808.50 $\mathrm{km} 2$ and can be divided into two plains, the lowland area with 69,768 ha (18.3\%) and the upland area with 311,082 ha (81.7\%). Kerinci Regency has an altitude between $500 \mathrm{~m}$ and $1,500 \mathrm{~m}$ above sea level and has an annual average temperature of about $22^{\circ} \mathrm{C}$. Moreover, the Regency is located along the Barisan Mountain range and is flanked by the highest mountains on the island of Sumatra, the 3,805 m Mount Kerinci, as well as Lake Kerinci and Lake Gunung Tujuh (Government of Kerinci Regency, 2012) .

Based on this geographical position, Kerinci Regency is a strategic area for observation. In general, the district has the following administrative boundaries: (1) to the north it is bordered by Solok Selatan Regency of West Sumatra province; (2) to the south it is bordered by the Merangin Regency of Jambi province; (3) to the west it is bordered by the Bengkulu Utara Regency of Bengkulu province, as well as Pesisir Selatan Regency of West Sumatra province; and (4) to the east it is bordered by Bungo and Merangin Regencies of Jambi province (Government of Kerinci Regency, 2009). Kerinci Regency itself has two defined areas based on geographic characteristics, namely the protected forest area and the agroforestry land. Law No. 4 of 1984 states that the implementation of development in one area should always focus on not only economic activities, but also on ensuring that natural resources are environmentally sound. 
Data from the Kerinci Regency government (2012) states that the protected areas in the regency account for 215,000 ha, or $51.19 \%$ of the total protected areas of the KSNP area. The area is meets the following conditions:

1) The area provides protection for lowlands, including protected areas, petland and water catchment area.

2) The local protection area includes river banks, the area around the lake or reservoir and the area around the spring.

3) Disaster-prone areas, namely areas that often experience or have high potential for experiencing natural disaster

Approximately 48 percent of the remaining land in Kerinci Regency is cultivated land, with the main function being production and business activities for human needs. The cultivated area is divided into 5 categories: (1) forest production area including areas for limited forest production, permanent forest production and conversion production; (2) mining area intended for ongoing and future mining activities; (3) agricultural area covering wetland food crop, dryland food crop, perennial crop or plantation, animal husbandry and fishery areas; (4) tourism zone intended for tourism-based activities; (5) settlement area utilized for residential purposes.

\subsubsection{Topography}

Data from the Kerinci Regency government (2012) explains that the topography of the district is generally divided into three categories, namely plateau, plains and lowlands. The altitude ranges from 500-2,500 meters above sea level. Most of the region, 152,757 ha $(45.89 \%)$, is located at an altitude of 1,000-1,500 meters above sea level, while the region above the altitude of 2,500 $\mathrm{m}$ above sea level covers an area of only 848 ha $(0.25 \%)$, with the region between 0-500 meters above sea level accounting for 3,535 ha (1.06\%) (Government of Kerinci Regency, 2012).

The Kerinci Regency territory has five slope classifications: Flat area is located on a slope of $0-2 \%$, sloping region is $2-15 \%$, wavy/hilly and quite steep is $15-40 \%$, and the steep region is $>40 \%$. Almost half of the territory within the regency $(35.53 \%)$ is an undulating terrain with a slope of $15-25 \%$, while the flat and relatively flat region only represents $26.55 \%$ to $24.75 \%$, for the $0-2 \%$ and $8-15 \%$ sloping terrain, respectively. The following is a detailed explanation of the slopes within the regency of Kerinci: 
1) The flat area with a slope of $0-2 \%$ accounts for $3.33 \%$ of the area within the regency. This slope classification is largely prevalent in the Sub-districts of Gunung Raya, Keliling Danau, Danau Kerinci, Sitinjau Laut, Air Hangat, Air Hangat Timur, Depati VII, Gunung Kerinci, Siulak, Kayu Aro and Gunung Tujuh.

2) Regions with a 2-15\% slope accounts for $15.62 \%$ of the area of Kerinci Regency, particularly in the Sub-districts of Gunung Raya, Batang Merangin, Keliling Danau, Danau Kerinci, Sitinjau Laut, Air Hangat, Air Hangat Timur, Depati VII, Gunung Kerinci, Siulak, Kayu Aro and Gunung Tujuh.

3) Regions with a slope of $15-40 \%$ is approximately $26.51 \%$ of the area of Kerinci Regency and is spread out across all sub-districts and sub-districts, but is the most prevalent in Gunung Raya, Batang Merangin, Keliling Danau, Danau Kerinci, Sitinjau Laut, Air Hangat, Air Hangat Timur, Depati VII, Gunung Kerinci, Siulak, Kayu Aro and Gunung Tujuh.

4) Regions with a slope of $>40 \%$ is the largest percentage, with about $53.05 \%$ of the area within Kerinci Regency, spreading across the sub-districts of Gunung Raya, Batang Merangin, Keliling Danau, Danau Kerinci, Sitinjau Laut, Air Hangat, Air Hangat Timur, Depati VII, Gunung Kerinci, Siulak, Kayu Aro and Gunung Tujuh

In general, the area within Kerinci Regency may be grouped into several units of morphologies, namely terrain, smooth undulating hills, medium undulating hills and mountain chains. More northern areas are affected by a higher morphology, i.e., undulating hills to mountain chains, while areas to the south are affected by lowland morphology and relatively similar rocks. These conditions certainly affect the spreading of natural resources and are necessary to keep as a consideration in determining the space allocation in the future (Forestry and Plantation Office of Kerinci Regency, 2010; Government of Kerinci Regency, 2012; Hendratmoko \& Pratiwi, 2013).

\subsubsection{Transportation systems and accessibility}

Kerinci Regency can be reached by several types of land and air transportation methods and has transportation facilities such as bus stations, airport and river ports (docks). Land transportation exists in the form of road networks and plays an important role in achieving equitable development, economic growth and the realization of social justice for all people. Kerinci Regency has a road network of $937.45 \mathrm{~km}$ that are defined as district roads. 
As of 2010 , it is known that $24.5 \%$ of the roads are in good condition, $18 \%$ had minor damage and $17 \%$ were classified as having a totally damaged condition. To support the movement of the traffic flow for both people and goods to and from Kerinci Regency, modes of transportation such as buses and mini buses (private travel business) are available and are generally concentrated in the city of Sungai Penuh, which is also the capital of Kerinci Regency, with the location of terminals/stops being available throughout the region.

Since 2002, Kerinci Regency government has sought the re-activation and continued development of the Depati Parbo airport located in Sitinjau Laut Sub-district. Aviation activities at the Depati Parbo airport are currently served by Fokker 50 aircraft with flight routes: Pekanbaru-Jambi-Kerinci, Kerinci-Jambi- Pekanbaru - Malaka - Medan - Batam Pekanbaru. Construction of the facility at the Depati Parbo airport has not been fully realized as of yet due to the limitations of the local government's budget. Some of the activities that have not been implemented include land acquisition and construction work. Regarding construction work, the runway was extended only to a length of $1,400 \mathrm{~m}$ by $30 \mathrm{~m}$, although an original length of $1,800 \mathrm{~m}$ was planned. Additionally, the taxiway with a size of $62.25 \mathrm{~m}$ by $15 \mathrm{~m}$ and an apron measuring $60 \mathrm{~m}$ by $44.65 \mathrm{~m}$ were also constructed in accordance with the master development plan of the existing Depati Parbo airport. To reach areas that are exceedingly far, as well as in an effort to make use of the river, the regency government is in the process of developing river transport infrastructure. The Kerinci district water system, namely Lake Kerinci with an area of 4,493 ha is spread throughout three sub-districts: Danau Kerinci, Keliling Danau and Bukit Kerman. Currently, Lake Kerinci is utilized for aquaculture and tourism by the public. Considering the existing conditions and the potential for the lake, it is likely to be developed as one of the economic clusters that connects the subdistricts in the surrounding areas through the development of the lake transport system, specifically with the development of lake docks as a point of water movement and transport purposes.

\subsubsection{Hydrology}

KSNP is a tropical forest that has at present a high hydrological value for all four of its local areas. In Kerinci Regency, the potential for abundant water resources is due to its high location, mountainous topography conditions and intense forests. Most rivers found in the region lead into Lake Kerinci, before flowing through Batang Merangin River to the east 
coast of Jambi province. The Batang Merangin River is the largest river in Kerinci Regency, although there are several other rivers within Sub-district, such as the Sikai River, the Semurup River and the Terung River. Currently, some river flows become the source of potential water energy in Kerinci Regency and consists of macro-hydropower (capacity>10 MW) and micro-hydropower (capacity $1 \mathrm{MW} \mathrm{s} / \mathrm{d}<10 \mathrm{MW}$ ). Batang Merangin Sub-district in particular utilizes the water flow of the Batang Merangin river's capacity of $180 \mathrm{MW}$.

Within Kerinci Regency, many small, medium and large rivers flow in various directions; most, however, flow towards the east. The upstream areas are usually located in the mountains and flow to the west (lower area), which is downstream, before emptying into the Batanghari River. Therefore, the Batanghari River is the estuary of the rivers in the western part, that is upstream rivers, as well as those in the mountainous areas or plateaus. Large rivers such as Batang Merao, Buai, Jujun, Batang Sangkir, Batang Merangin, Betung Kuning, along with a large number of other rivers are split into small and medium rivers. In addition to rivers, there are also lakes and swamps that have a plethora of biodiversity, such as Lake Gunung Tujuh, Lake Belibis, Lake Kerinci, Lake Lingkat, Lake Padeang, Lake Kaco and Lake Kecik, and many swamps are scattered throughout the lowlands. The river systems flowing throughout the district can be classified into two groups, namely: (1) the river system which is part of the upstream parts of major rivers, such as the Batang Merangin watershed; and (2) the river system which is a major watershed system such as the Merangin watershed.

As most of the areas are passed by several major rivers, Kerinci Regency has a relatively abundant river surface water potential. This condition is reflected by most of the existing rivers that do not experience droughts throughout the year, so the surface water potential is huge. In addition to the great river potential, the conditions of river water and a lot of surface water in some areas occurs over land flow. Thus, in many areas, flooding and inundation commonly occur.

\subsection{Social conditions}

\subsubsection{Population conditions}

Data from the local government and the Statistics of Kerinci Regency (2013) state that the total population of Kerinci Regency in 2012 was 235,797 inhabitants, with 117,585 male and 118,212 female inhabitants. The growth rate of Kerinci Regency population within the 
last 12 years (2000-2012) was $0.64 \%$ per year, while the population density in 2012 was 62 people/km2, indicating that the district experienced high population development/explosion in each district and sub-district that became a center of activity. Based on data from the Statistics of Kerinci Regency, it is known that the population structure of school aged (5-19 years) individuals reached $26.79 \%$, while the population of university aged (20-24 years) citizens reached 78,318 inhabitants, or 34\%, of the total population in 2011.

\subsubsection{Education}

Education infrastructure facilities in Kerinci Regency are also very important for improving social conditions within the community. Currently, educational infrastructure in the district are not evenly distributed, especially with regards to the span of control among villages that are quite far apart, particularly in rural areas. This results in difficulties with the distribution of educational infrastructure and facilities. If the placement of infrastructure and facilities is based on national indicators which refer to a relatively dense community and short-range control, the provision of educational infrastructure definitely cannot be reached by school-aged children. Therefore, the placement of educational infrastructure and facilities tends to be based on the distribution of the spread of settlements, especially for basic education (primary school). This spread is adjusted according to the spread of settlements, so that almost every village has a primary school even when the number of students does not meet the minimum students per class requirement (Government of Kerinci Regency, 2009).

The distribution of infrastructure and facilities for junior high and senior high/vocational schools is also uneven. In fact, there is a buildup of schools in urban areas, while other areas have just a few schools. Moreover, the number of school-age children is much greater than the capacities of the schools. As a result, it is possible that there are many school drop outs (Government of Kerinci Regency, 2012). Table 19 describes the condition of educational infrastructures in general. 
Table 19 Total education infrastructures and facilities in 2007 by level of education

\begin{tabular}{|c|c|c|c|c|c|}
\hline No & Education level & $\begin{array}{l}\text { Number } \\
\text { of school }\end{array}$ & $\begin{array}{c}\text { Total } \\
\text { classes }\end{array}$ & $\begin{array}{c}\text { Total } \\
\text { students }\end{array}$ & $\begin{array}{c}\text { Total } \\
\text { teachers }\end{array}$ \\
\hline \multirow[t]{6}{*}{1.} & Elementary Schools & & & & \\
\hline & - State School & 297 & 1.761 & 35.300 & 2.322 \\
\hline & - Private School & 2 & 17 & 610 & 15 \\
\hline & - State Islamic School & 24 & 377 & 8.960 & 108 \\
\hline & - Private Islamic School & 4 & 31 & 725 & 102 \\
\hline & $\begin{array}{l}\text { - Disabled } \\
\text { - SDLB }\end{array}$ & & & & \\
\hline \multirow[t]{5}{*}{2.} & Junior High School & & & & \\
\hline & - State owned School & 50 & 473 & 12.462 & - \\
\hline & - Private School & 1 & 3 & 62 & - \\
\hline & - State Islamic School & 18 & 117 & 2.886 & 433 \\
\hline & - Private Islamic School & 8 & 36 & 820 & 141 \\
\hline \multirow[t]{7}{*}{3.} & Senior High School & & & & \\
\hline & - State School & 15 & 192 & 7.119 & 376 \\
\hline & - Private School & 4 & 15 & 80 & 314 \\
\hline & - State Vocational School & 5 & 76 & 217 & 2.188 \\
\hline & - Private Vocational School & 1 & 3 & 22 & 101 \\
\hline & - State Islamic School & 5 & 51 & 1.967 & 163 \\
\hline & - Private Islamic School & 5 & 16 & 318 & 67 \\
\hline
\end{tabular}

Source: Government of Kerinci Regency, 2012

\subsubsection{Health}

The existing health facilities in Kerinci Regency consist of hospitals, public health centers and public health posts. In general, health facilities in the regency are dominated by public healthcare service (approximately 40 facilities). Health development has manifested through the provision of health infrastructure and facilities, which until the end of 2007 was done optimally, particularly with regard to the provision of health services which are affordable and easily accessible to the public. Provision of health infrastructure and facilities 
in Kerinci Regency, consisted of, until recently, the General Hospital with a capacity of 111 in-patient beds, 4 VIP beds and 2 VVIP beds, as well as one private hospital with an inpatient capacity of 50 beds. In addition, the service support for the public was also carried out through the provision of a Regional Technical Implementation Unit consisting of 20 public health centers composed of 50 public health posts and 81 village midwives. The number of health workers in Kerinci Regency in 2007 was 10 specialist doctors, 38 general practitioners, 11 dentists, 5 pharmacists, 13 assistant pharmacists, 52 midwives , 95 nurses, 38 sanitation workers, and 74 paramedics/nurses.

These figures are considered to be sufficient in terms of the national average for a similar sized area in terms of density, except for the figure for village midwifes which is below the national average. However, the village midwife ratio is still below the national one. Problems faced with respect to healthcare facilities lie primarily in the uneven distribution of the population, where one village and another are quite far apart, have poor infrastructure conditions, and inadequate transportation facilities so that the existing health care facilities cannot reach all levels of society.

\subsection{Economic conditions}

\subsubsection{Livelihood}

One of the indicators of well-being of a region is how the region's contribution of gross domestic product (GDP) shows the added value generated by economic components. Referring to the statistical data released by the Statistics Bereau of Kerinci Regency in 2013, it is apparent that agriculture, animal husbandry, forestry and plantations contributed most to the region's GDP, i.e., 67.04 percent of the total GDP (Rp 40,305,346.7). The percentage contribution to GDP is very asymmetrical when compared to the economic contribution service activities such as telecommunications, transportation and mining.

When observed further, it can be determined that there are two agriculture sub-sectors that contributed most to the GDP, namely food and plantation crops. Both sub-sectors are the main business fields for the source of livelihood of the people in Kerinci Regency. However, the majority of the agricultural commodities from the region do not undergo additional industrial/manufacturing processing. The second largest contributor is the services sector, especially government services, hotels and restaurants, while the largest contribution comes from the trade sub-sector. Trading activities are mostly retail trade of agricultural 
commodities in addition to other commodities that are imported from other regions or overseas, including processed food products.

\subsubsection{Community land status and area}

Land use in Kerinci Regency has undergone many significant changes due to land conversion efforts and the occupation of the areas that have commercial rights. Several types of existing land use can be distinguished, including settlements, fields, bush, forest, field, moor, human, and plantation. All of these can essentially be divided into areas that are either cultivated or undeveloped land. The two groups can be described as follows:

\section{a. Cultivated Land}

Cultivated land is an area where communities do specific production activities in an effort to meet their needs. Included in this group are rice fields, settlements, moor/fields, orchards and mixed plantations. This land type, when considered with the vast area of Kerinci Regency, utilizes approximately 46 percent, or 311,076 ha. This land is distributed in the seven sub-districts in Kerinci Regency. The details of each type of land use are as follows:

Settlement. The use of land for settlement in Kerinci Regency is 3,345 hectares, or 0.80 percent, of the regency area. The utilization of the area is still relatively small which is consistent with the total population density within the district. Furthermore, the center of this settlement is mostly in urban areas and towns in the sub-districts. As for the rural areas that are still scattered throughout, the average settlement requires only a relatively small area, assuming a house for a household with family members of 5 people on average.

Rice Field. Land used for rice cultivation in Kerinci Regency covers an area of 16,630 ha, or $3.96 \%$ of the district area and the rice fields are found in each sub-district. The majority of the rice production is carried out through simple irrigation. However, there are also rice fields which have technical and semi-technical irrigation systems. In addition to the area, there is still sufficient potential for rice production development. However, it has not been able to be utilized properly, so that it only serves as marginal land. In the future, it is expected that the idle land will be capable of being potentially productive land.

Moor/Field. The majority of moor/field land is used for various types of public purposes. For the transmigration area, it is generally planted with various types of crops, such as rice, fruits and various kinds of vegetables. The dryland/fields in the areas of indigenous people are usually planted with perennials such as cinnamon and rubber, and are occasionally 
planted with vegetables and fruit crops, while crops such as rice are usually produced by opening new land. The area of existing dryland/moor is about 36,450 hectares, or $8.68 \%$ of the district area.

Mixed Garden. The use of land for mixed garden is generally found around housing or settlement areas. In fact, this type of land is also widely planted by the community on the edges of roads and large rivers with fruits such as rambutan, lanseh, durian, banana and coconut. The area of these mixed garden is 3,625 hectares, or $0.86 \%$ of the district area.

Plantation. The use of land for plantations is the most extensive type of land use within the community. Various types of commodities intended for export have been extensively planted by the community. Commonly grown plants include cinnamon, tea, coffee and rubber. These commodities are generally owned by smallholders and nationally-owned plantations. The plants of smallholder are usually tree-mixed plantations, with forest plants and shrubs due to lack of maintenance. Plantation areas account for 120,587 hectares, or $28.71 \%$ of the regency area.

\section{b. Undeveloped land}

Undeveloped land is essentially a backup area, as well as being a protected area. This group includes forests, shrubs, bushes and grassland, and accounts for an area of 4,471 hectares, or $1.06 \%$ of the regency area. Details related to the areas as follows:

Forest area. The existing forest area in Kerinci Regency is basically a forest area which serves as a protected area in an effort to maintain natural balance, specifically hydrological. Moreover, tropical rainforests are included in this category. Based on the results of the investigation on the land use and spatial planning of Agreed Functional Forest Classification, i.e. forest land-use plan (Tata Guna Hutan dan Kesepakatan) and the decree of Minister of Forestry No. 173 / Kpts-II / 1986, the forest area in the regency of Kerinci can be classified into: Community forest/nature reserve with an area of 1,679 ha, nature reserve forest with an area of 60 hectares, natural park forest with an area of 20 hectares, national park forest with an area of 215,000 ha, production forest for community participation with an area of 30,490 ha, and city forest with an area of 21 hectares. The description above clearly shows that the use of land in Kerinci Regency can generally be categorized into two types of use, namely the forest zone with an area of 45.98 percent and the non-forest zone with an area of 54.02 percent. 


\section{Chapter V. Perceptions and Interactions of Local Community towards the Surrounding Natural Environment: Findings from the Empirical Study}

The greatest challenge of forest management is the dependence of rural communities on agriculture and forest products. Therefore, one of the strategies in addressing this problem is to establish protected areas such as national parks throughout parts of the tropical forests in Indonesia. An institutional body needs to be established to safeguard the ecological integrity of the area in the long term (Mehring et.al, 2011). The institution establishes a set of working rules that are used to determine who is qualified to make decisions related to permitted or restricted actions in a particular area (Ostrom, 1990).

Forests serve natural resource functions, not only as sources of business for their surrounding communities, but also as places of residency (Purwanto, 2005). Moreover, community members do not rely on forests only as a source of energy, but also as a place for their livelihoods (Führer, 2000; Defries, Hansen, Turner, Reid, \& Liu, 2007). The existence of a protected forest, which in this study is Kerinci Seblat National Park (KSNP), has both positively and negatively impacted the perceptions and interactions between man and the natural environment. The daily life of the surrounding community is directly and indirectly tied to the existence of the forest area. The major occupations of those living in Kerinci Regency, especially in the four villages considered in the current research efforts, are farmers and fishermen (in Lake Kerinci). These are relevant for policies or programs made by the local government, as well as the KSNP managers, which should attempt to be beneficial for both local communities and the conservation of biodiversity.

This chapter discusses the perception as well as the interactions of the local communities, regarding the existence and utilization of the natural environment surrounding KSNP. This relationship is expected to be able to explain that local communities and the national park manager are the main actors in making sense, utilizing, and conserving the natural environment. Specifically, this chapter emphasizes respondents' perceptions towards natural resources, natural preservation activities or conservation, and the potential for tourism, especially with regards to the extensive potential for ecotourism in Kerinci Regency and throughout the KSNP area. Those aspects are expanded upon through further investigations regarding the perception of respondents toward knowledge and utilization of forest resources, as well as consideration of the local livelihood that relies on the existence of forest areas. 
These concerns are further explored in an attempt to understand the respondents' perceptions related to the utilization of the border area, the management of the KSNP problems, the rights over the land authority, as well as the agrarian history of the area. The perception of tourism potential is investigated through questions about the respondents' viewpoints related to tourism attractions and thrive the local culture, factors which are commonly associated with communities acting against existing natural resources. From this interaction, perspectives were gathered related to the collaboration between communities and the natural environment, as well as KSNP.

The study was conducted primarily in the following four villages: Lindung Jaya, Pelompek, Lempur Tengah, and Sanggaran Agung. Considering the geographical condition of these areas, the villages were divided into two groups: Lindung Jaya and Pelompek which represent the northern part of the regency, and Lempur Tengah and Sanggaran Agung which represent the southern part of the regency. The data were collected by interviewing the 80 respondents through in-depth discussions, open discussions and focus group discussion (FGD). The key respondents included various layers of society, for examples, the head of the indigenous people named "Depati', the head of the farmers group, the village chief, youth and religious figures, farmers, landholders, tea pickers and members of local communities. Table 20 describes the number of respondents and characteristics of respondents. 
Table 20 Characteristic of respondent

\begin{tabular}{|c|c|c|c|c|c|c|c|c|c|c|}
\hline \multirow[b]{2}{*}{ No } & \multirow[b]{2}{*}{ Characteristics } & \multirow[b]{2}{*}{ Variable } & \multicolumn{4}{|c|}{ Respondent (absolute) } & \multicolumn{4}{|c|}{ Respondent $(\%)$} \\
\hline & & & Pelompek & $\begin{array}{c}\text { Lindung } \\
\text { Jaya }\end{array}$ & $\begin{array}{l}\text { Lempur } \\
\text { Tengah }\end{array}$ & $\begin{array}{c}\text { Sanggaran } \\
\text { Agung }\end{array}$ & Pelompek & $\begin{array}{c}\text { Lindung } \\
\text { Jaya }\end{array}$ & $\begin{array}{l}\text { Lempur } \\
\text { Tengah } \\
\end{array}$ & $\begin{array}{c}\text { Sanggaran } \\
\text { Agung }\end{array}$ \\
\hline \multirow[t]{5}{*}{1} & \multirow{5}{*}{$\begin{array}{l}\text { Educational } \\
\text { level }\end{array}$} & None & 0 & 0 & 0 & 0 & 0 & 0 & 0 & 0 \\
\hline & & Junior high school & 4 & 6 & 6 & 2 & 26.67 & 30.00 & 24 & 10 \\
\hline & & Senior high school & 7 & 10 & 10 & 9 & 46.67 & 50.00 & 40 & 45 \\
\hline & & Bachelor & 3 & 2 & 8 & 8 & 20 & 10.00 & 32 & 40 \\
\hline & & Doctor & 0 & 0 & 0 & 0 & 0 & 0 & 0 & 0 \\
\hline \multirow[t]{4}{*}{2} & \multirow[t]{4}{*}{ Age } & $<30$ years & 4 & 4 & 4 & 1 & 26.67 & 20.00 & 16 & 5 \\
\hline & & $31-50$ years & 6 & 12 & 16 & 16 & 40 & 60.00 & 64.00 & 80 \\
\hline & & $51-70$ years & 5 & 4 & 5 & 3 & 33.33 & 20.00 & 20.00 & 15 \\
\hline & & $>70$ years & 0 & 0 & 0 & 0 & 0.00 & 0 & 0 & 0 \\
\hline 3 & $\begin{array}{l}\text { Number of the } \\
\text { family } \\
\text { members }\end{array}$ & None & 4 & 3 & 5 & 2 & 26.67 & 15.00 & 20.00 & 10 \\
\hline \multirow[t]{2}{*}{4} & \multirow[t]{2}{*}{ Occupation } & Farmer & 10 & 12 & 15 & 12 & 66.67 & 60.00 & 60.00 & 60 \\
\hline & & Non farmer & 5 & 8 & 10 & 8 & 33.33 & 40.00 & 40.00 & 40 \\
\hline \multirow{4}{*}{5} & \multirow{4}{*}{$\begin{array}{l}\text { Monthly } \\
\text { income } \\
\text { (IDR) }\end{array}$} & $<500$ thousand & 0 & 0 & 0 & 0 & 0.00 & 0.00 & 0.00 & 0 \\
\hline & & $\begin{array}{l}500 \text { thousand - } 1 \\
\text { million }\end{array}$ & 4 & 4 & 7 & 5 & 26.67 & 20.00 & 28.00 & 25 \\
\hline & & $1-2$ million & 9 & 14 & 14 & 12 & 60.00 & 70.00 & 56.00 & 60 \\
\hline & & $>2$ million & 2 & 2 & 4 & 3 & 13.33 & 10.00 & 16.00 & 15 \\
\hline \multicolumn{3}{|c|}{ Subtotal } & 15 & 20 & 25 & 20 & 100.00 & 100.00 & 100.00 & 100 \\
\hline \multicolumn{3}{|c|}{ Total of respondents } & \multicolumn{4}{|c|}{80} & \multicolumn{4}{|c|}{100.00} \\
\hline
\end{tabular}




\subsection{Characteristics of the respondents}

Respondents from the four villages, namely Pelompek (sub-district of Gunung Tujuh), Lindung Jaya (sub-district of Kayu Aro), Sanggaran Agung (sub-district of Danau Kerinci) and Lempur Tengah (sub-district of Gunung Raya), were analyzed based on the following characteristics: level of education, age, occupation, number of the family members, and monthly income. Based on the educational level, the majority of respondents in all four sub-districts have strong educational backgrounds, with most of them being high school graduates. Moreover, this means that the ability of the respondents to appropriately respond to the questions or to read and write is more than sufficient. Most of the respondents were of productive age (31-50 years old); thus, it can be assumed that the respondents have a good perception of the relationship between the natural environment and the people surrounding it, as well as having an idea of what problems may occur.

The majority of the respondents in all four sub-districts listed three to five family members, a characteristic which is closely related to the overall livelihoods of the respondents. Most work as farmers, including tillage and gardening practices. It is relevant to determine the relationship with regards to whether large familial responsibilities (3-5 persons) have an implication on the perspective of respondents relating to their treatment of natural resources. Based on empirical studies, the treatment of the local population in these sub-districts against the natural resources is not the same. The respondents' perceptions are discussed in greater detail in the next sub-chapter. The income factor leads to another interesting finding in relation to the respondents' characteristics. The same percentage of respondents (60-70\%) in Lindung Jaya Village earned either above IDR one million or below IDR two millions per month. Similarly, in the other three villages; Pelompek, Lempur Tengah and Sanggaran Agung, the majority of the respondents also earned above IDR one million and below IDR two millions but the percentage is below that of Lindung Jaya Village.

The pattern of land utilization in the four sub-districts is also different. The subdistrict of Kayu Aro (Lindung Jaya) and the sub-district of Gunung Tujuh (Pelompek) lie in the northern area of Kerinci Regency, where the majority of the land is planted with vegetables and seasonal plants. Whereas farmers in the other sub-districts generally prefer to plant perennial and annual commodities such as cinnamon and rice. Furthermore, the relationship between man and nature is influenced by how the local people perceive the 
available natural resources, as well as how land and environmental resources are utilized; this relationship will be elaborated on in the next sub-chapter.

The spread of ethnicity in the regency of Kerinci can be easily identified based on geography. The sub-districts of Gunung Tujuh (Pelompek) and Kayu Aro (Lindung Jaya) were originally part of one district, Kayu Aro. Then, this sub-district was further divided into three sub-districts, namely Kayu Aro Barat, Kayu Aro and Gunung Tujuh. Ethnically, the majority of the population in Gunung Tujuh is originally Kerinci ethnic and other ethnicities such as Minangkabau and Javanese. The majority of the communities in Kayu Aro Sub-district is Javanese, while the remaining members are part of Kerinci tribe and Minangkabau tribes. The major ethnicities of the community in Sanggaran Agung Village are the native ethnicities of Kerinci, Minangkabau and Javanese (minority). Nearly all of the inhabitants of Lempur Tengah Village are from the indigenous ethnicity of Kerinci, with a small percentage of migrants coming from West Sumatra and Java.

The results of the analysis are based on the current empirical study, however, these results show little differentiation from the statistical data issued by the Statistics of Kerinci Regency in 2013. The report shows that most of the communities in the surrounding areas, particularly those who live around the circumference of Sanggaran Agung, work as farmers, laborers, seasonal workers, tea pickers and fishermen.

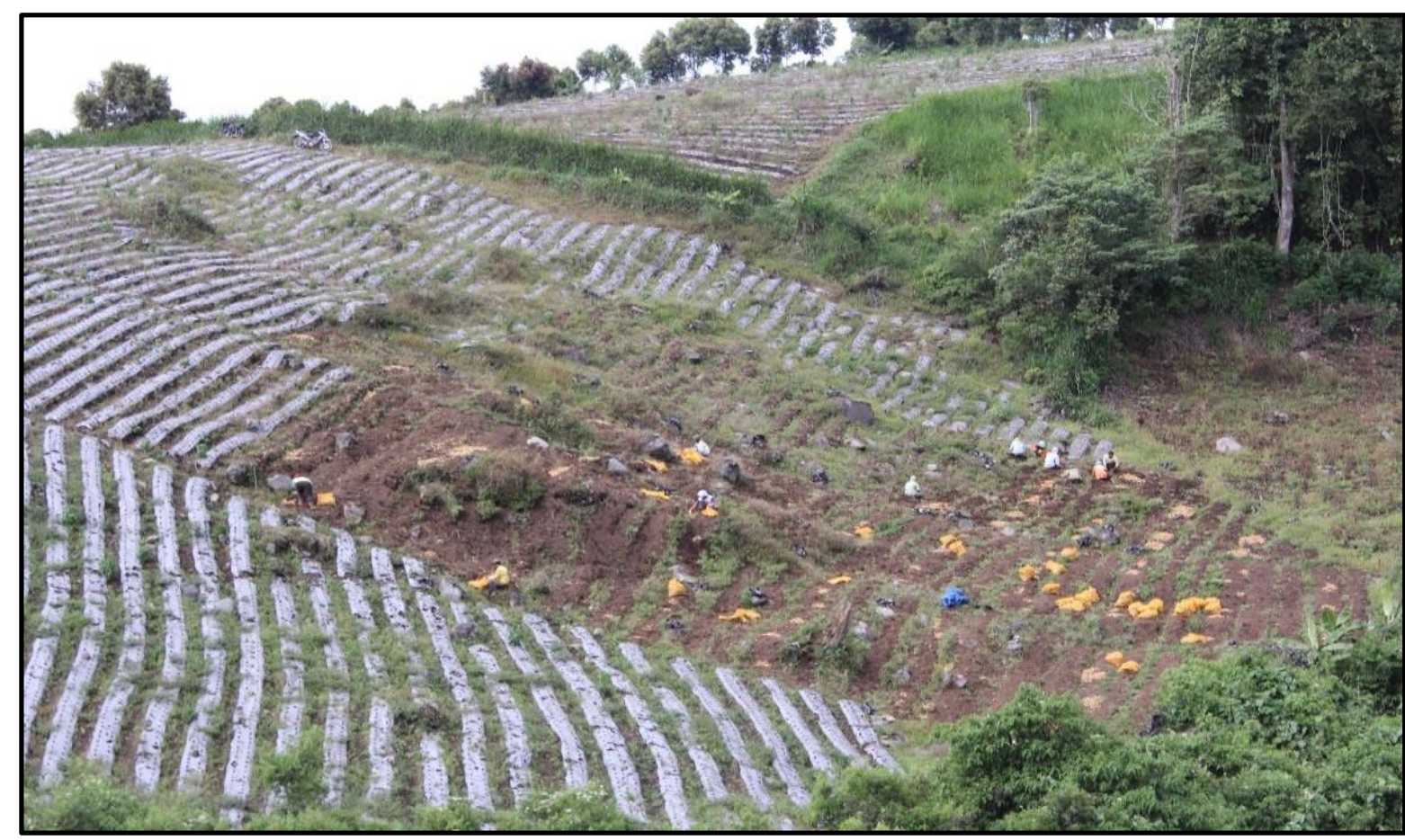

Source: Author's photo

Picture 5 Production activities of local horticulture farmers in Kayu Aro Sub-district 


\subsection{Findings of the empirical study from the viewpoints of local communities}

\subsubsection{Local community's perceptions and interactions with forest resources, the environment and KSNP}

The public perception of the natural resources environment in this study includes knowledge of the natural environment, i.e., the forest and KSNP, the boundaries of the area, the rights to the land authority and management, as well as customary laws and local culture. Based on the results of the interviews, it has been determined that the communities within the regency of Kerinci generally have a good understanding of the existence of forests, protected forests, and conservation forest areas in the KSNP area. Moreover, most of the respondents were able to define the differences between customary forests and protected forest such as the national park in their own language. Wahyuni \& Mammonto (2012) stated that information related to public perception of the existence of the national park has a significant meaning, because it is associated with the success of the park's management efforts. Communities' understanding of the existence and functions of the national park will also affect public participation in the management of the park.

There are several factors which help to make the community aware of the differences between production, protected, and conservation forests, such as KSNP. First, word-ofmouth has a significant role in transferring knowledge through generations; second, local communities often face the conflicts of land utilization, such as the prohibition of entering forest area (especially within KSNP), with national agency. This situation drives community members to seek information and learn more about the restrictions. Third, government officers, both locally and nationally, as well as KSNP officers, often visit the communities in an effort to spread information about forest encroachment. Researchers and NGOs are also known to come to residents for interviews and to give a better understanding of the matter. Fourth, local communities are sometimes invited to attend meetings, ranging from the village level to the regency level and even occasionally the national level, to discuss the existence of forest resources near their residences.

Interactions among local populations occur often and have been taking place for an extended amount of time within these forums, allowing community members to fully grasp the situation and develop an idea of how they should make the use of the natural environment. Nevertheless, the real situation sometimes does not go as expected. Generally, it is not easy to ask the local community to leave their homes as they have inhabited and 
made a living in these locations for generations. For them, the forest is not only a place of doing business, but is also a place to live.

This situation has led the local government of Kerinci Regency, as well as KSNP managers to develop an opinion that these local communities will likely be the main cause of damage to the natural environment. This concern is very reasonable, as realistic conditions have confirmed it in several cases. According to one of the respondents in the current study, 500 hectares of the KSNP area has been exploited for farming cultivation and tillage in the sub-districts of Kayu Aro and Gunung Tujuh for long period of time. Referring to the official data of the KSNP authority, the total conservation that has been exploited in the two districts reaches 6,775 hectares.

',The local community that had already exploited the area before KSNP was designated as conservation areas continue to cultivate the area. It is difficult for the KSNP manager to "remove" the cultivation of agricultural land from the area. It is estimated that the area cultivated by the community is approximately 500 acres surrounding this village", (Respondent 12, KSNP ranger in Gunung Tujuh resort / entrance).

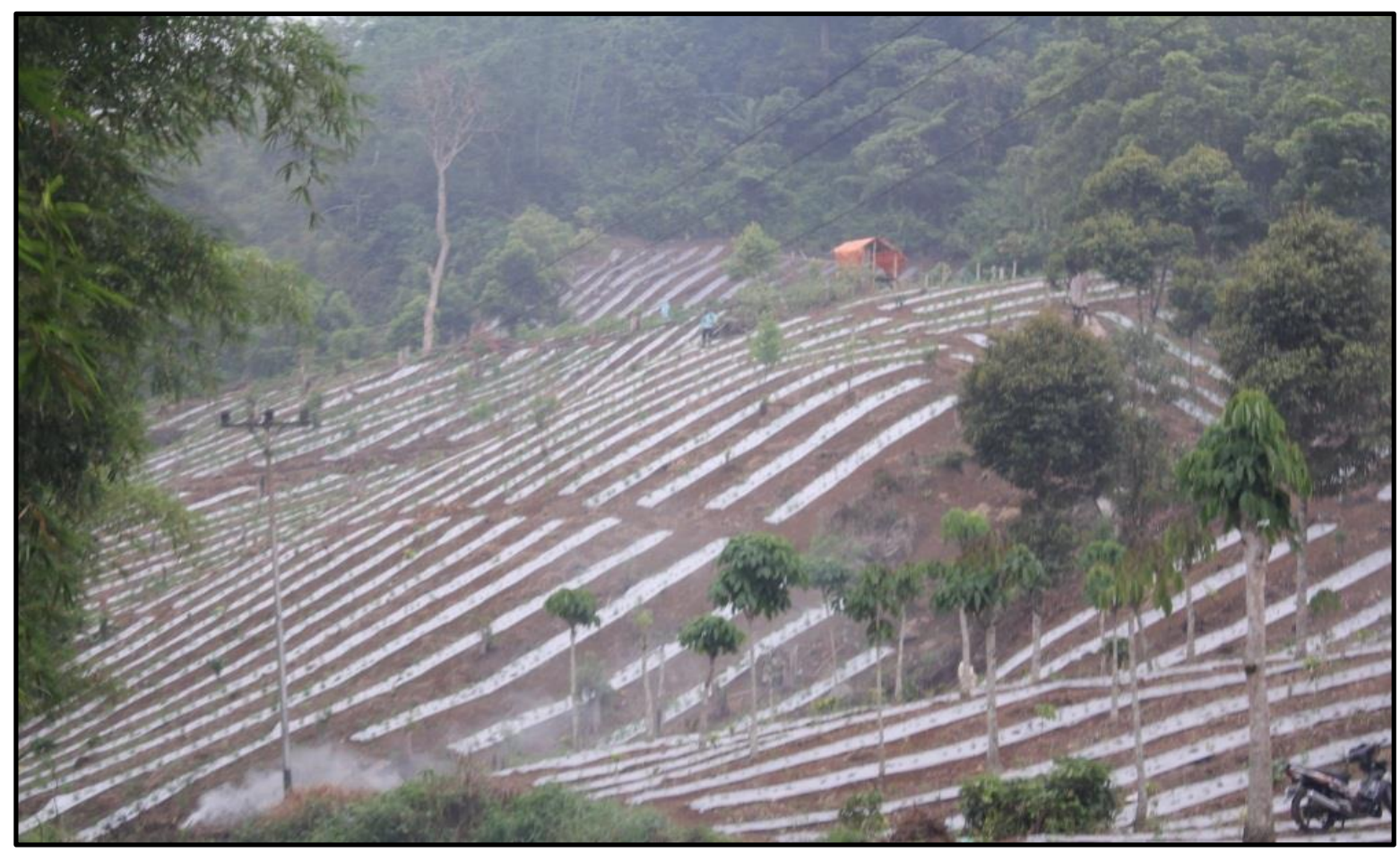

Source: Author's photo

Picture 6 An agricultural area in the KSNP area located in Gunung Raya Sub-district 


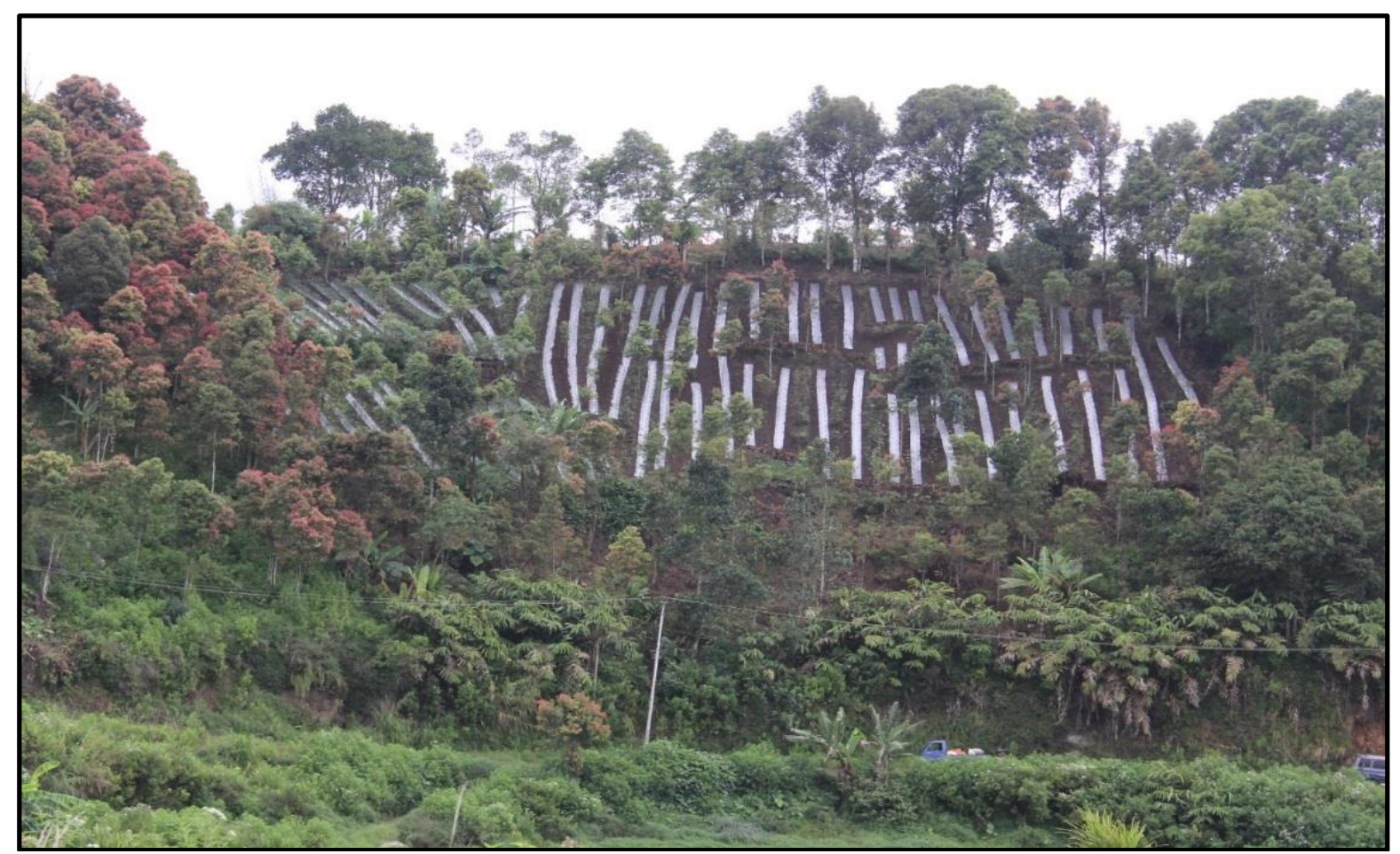

Source: Author's photo

\section{Picture 7 A cultivated land in the KSNP area located Gunung Tujuh Sub-district}

\subsubsection{The diverse perspectives of four local communities regarding the utilization of conservation areas}

The government sees cases of destruction of nature, including illegal logging and wild forest logging, which often occur in forests of KSNP, as actions that are breaking the law and ultimately concerned with the negative impact that these actions have on the forests. Some of the public figures from the four villages that were interviewed for this study have different views. According to these respondents, the communities of Kerinci Regency, particularly the original communities of Kerinci, are unable to damage the forest or natural resources because they understand that the applicable law prohibits it. In each sub-district, there is a "Depati"' who regulates custom policies of continuity. Therefore, the local populations are very mindful of maintaining nature that gives sustenance to the communities. The Depati is the leader of the indigenous community within Kerinci Regency (Agung \& Idris, 2001; Natividad \& Neidel, 2003).

The indigenous communities maintain forest resources in the surrounding area, most of which belong to KSNP, with one condition: That no one will interfere with the forest area that has become a livelihood for local communities, as well as it is being a place that has been established according to the rules of the customs. For example, both migrants and 
original community members who cut down the forest will be punished. In other words, they will be punished by the custom law first and may also be brought to a trial by the government or police. This is evidence of the love of nature that the indigenous people of Kerinci have for the surrounding environment. Another view is related to horizontal conflicts; specifically, conflicts which often arise among residents. Local communities generally have different opinions than those of the government. According to the respondents, conflicts typically occur over small problems, but they are frequently overstated by a third party who interferes in the conflict and provokes negative behaviors. Unfortunately, respondents were not able to thoroughly explain who this third party is.

Regarding knowledge of forest functions, people who work, particularly farmers, and live around the national park have a good understanding of the functionality and utility of the forest as a water provider, anchor to avoid erosion and flood deterrent, and even recognize that the forest is defined as a support system for human life, as well as for other organisms. The forest should not be tampered with as it is a provider of water and it is invaluable for the sustainability of farms and fields. Knowledge of the functions of forests and the importance of maintaining the sustainability of the natural resources within Kerinci communities comes from the knowledge that is handed down to community members through generations. This knowledge has been internalized in the form of customary law and nearly all of the local communities in the regency of Kerinci believe that nature and forests must be preserved as a source of livelihood. There is even an expression held by the community in the villages of Lempur Tengah and Sanggaran Agung, that "No tree may be broken'. This expression means that the Kerinci community should always maintain the sustainability of its forests from generation to generation.

\subsection{Perceptions and interactions of the Lindung Jaya and Pelompek villagers related to natural resources}

The villages of Lindung Jaya and Pelompek lie at the foot of Mount Kerinci and Gunung Tujuh Sub-district. As mentioned before, administratively, Lindung Jaya belongs to Kayu Aro Sub-district and Pelompek belongs to Gunung Tujuh Sub-district. Before 2008, there was only one sub district, namely Kayu Aro. In an effort to further develop and improve the well-being of local residents, Kayu Aro was further divided into three subdistricts, i.e., Gunung Tujuh, Kayu Aro, Kayu Aro Barat.

Demographically, the residents who occupy Lindung Jaya and Pelompek are differentiated into two categories, namely the descendants of the original Kerinci, and mixed 
tribes of Kerinci- Minangkabau or Kerinci-Javanese. The majority of the villagers of Lindung Jaya are of Javanese ethnicity. An individual who is currently 30 -years old is likely the fourth or fifth generation of Javanese people in the regency of Kerinci. Meanwhile, most of the villagers of Gunung Tujuh are the original descendants of Kerinci mixed with the descendants of the Minangkabau/Padang tribe. Therefore, many traditions, such as dances, songs and cultural elements of the people in these areas are similar to those in West Sumatra, the area where the Minangkabau tribe originated. Geographically, the Javanese community is easily identified as they predominately settled in a location which is not far from the tea plantations and the foot of Mount Kerinci. The Kerinci-Minangkabau descendants are somewhat more concentrated in areas such as those around Gunung Tujuh mountain range and the border along the province of West Sumatra. Their residential fields are somewhat far away from the tea plantations.

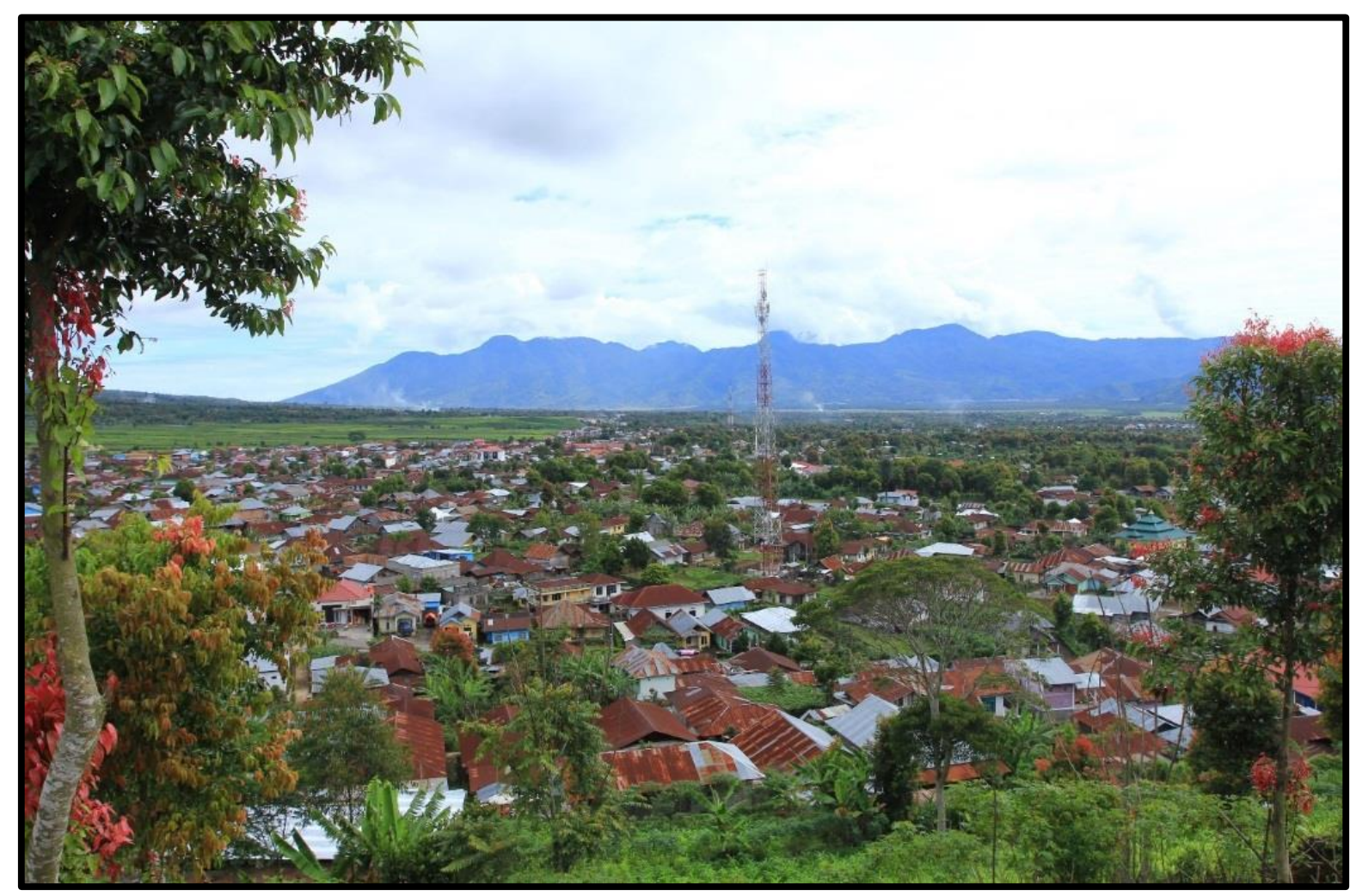

Source: Author's photo

\section{Picture 8 Residences in Lindung Jaya and Pelompek Villages}

The relative closeness between the current populations' residential areas and those of their ancestors allows the descendants of Java in Kerinci Regency, in Lindung Jaya Village, for example, to preserve their culture. Cultural performances such as the Kuda Kepang, wayang, traditional songs and traditional ceremonies, such as the Ketoresno, describe the human treatment of nature and can still be observed in these communities today. However, 
some aspects of the story or technical terms for certain aspects of these traditions have begun to experience cultural changes, so that modern performances have been adapted to consider modern stories.

The villagers of Lindung Jaya, specifically the Javanese descendants, often hold an annual event of offering at the foot of Mount Kerinci called the ceremony of Ketoresno. Ketoresno is a ceremony related to how humans treat nature and is packed in ritual and spiritual meanings. The ceremony describes the belief and trust, as well as the relationship between humans and nature, the ceremony further helps to develop a mentality that keeps people from damaging the environment. The meaning is that when nature is damaged, then man will also feel damaged. They believe that there are other creatures which maintain the forests and serve as a mediator between man and nature. The ceremony is followed by custom figures, community leaders, the leaders of cross villages and sub-districts. Community leader representatives are not only from the village of Lindung Jaya, but also from other parts of the sub-districts around Mount Kerinci, especially Javaness. They perform a ceremony that is a combination of belief by the religion of Islam with belief based on cultural traditions for generations. They will pray together according to religious rules of Islam, but each participant bring food to be placed in one place as offerings to the Mountain Kerinci guard that is believed to be invisible to human eyes.

The Ketoresno ceremony always takes place at the foot of Mount Kerinci, specifically, at the main entrance facing the forest of Mount Kerinci. The event is conducted in accordance with the Islamic calendar and coincides with the first of Muharram. Community leaders gather at the site and perform rituals and other activities, commonly prayers and offerings. The rituals and offerings are conducted to remind man that forests and mountains will get mad if humans cannot maintain and remain intimate with nature. Therefore, communicating with nature is very important to those who live and work around the forest, especially regarding the belief that the relationship helps to avoid disaster. The inhabitants bring traditional food and cut off the head of a buffalo as a form of agreement with nature. Offerings for the guard of the mountain are placed in a specific location and they ensure that no trace of the celebration is left behind. Cultural beliefs such as these lead to a binding relationship between nature and daily life in the community.

Local communities in Gunung Tujuh have similar, yet different, values that are displayed through their rituals related to utilizing natural resources; this ritual is called Kenduri Sko and is commonly conducted by communities in the southern areas of Kerinci Regency. The Kenduri Sko encourages people to give thanks for the good fortune obtained 
from farming, while the harvest is intended to be enjoyed and shared by the villagers. Usually, every household brings food and then everyone gathers in the field or in large custom-built homes to enjoy the meal together. Greeting and prayer according to Islam custom starts the event and then the community enjoys the meal together.

Although the majority of these cultural practices have been around for years, there is still some degree of debate surrounding the activities, as well as their effectiveness. Some communities, for example, have launched complaints that the activities of Ketoresno should use the head of a goat rather than of a buffalo due to some communities not being able to financially contribute towards the cost of a buffalo. Some respondents believe that cultural activities can increase the awareness of local communities, especially if they are done in conjunction with attention and agricultural assistance gained by the community from the local government and the managers of KSNP. Furthermore, such cultural activities rarely, if ever, establish collaborations with other actors in the region, such as the KSNP managers or the local government.

\subsubsection{Livelihoods and horizontal conflicts over land authority}

Based on geographical location, communities of Kerinci mention the northern part of the territory of Kerinci is the area of Mudik. In this part of Mudik, generally people do horticulture farming and crops. They plant their land with different types of commodities that can be quickly harvested like chilies, cabbages, and potatoes. Why do societies of the northern part of Kerinci prefer farming with horticultural commodities and vegetables? According to the respondents, such commodities are in accordance with the topography of the region, which is relatively higher than the southern part and has cooler climate. Other reasons say that the commodities can meet the economic needs of households in the region.

Since then, indigenous people of Kerinci have relied more on cinnamon as the main commodity of agriculture. This commodity is plentiful in Sanggaran Agung and Lempur Tengah, located in the southern part of the regency of Kerinci. Even the productivity of the cinnamon has introduced the region to the world and can sustain life. However, along with the changing times and needs of the household, the communities prefer to plant horticulture and crops as occurred in Lindung Jaya Village or most of villages in Kayu Aro Sub-district and Gunung Tujuh Sub-district where Pelompek village is located. At first the pattern of cultivation of vegetables and horticulture was performed by the Javanese communities who were more concentrate living in sub-districts of Kayu Aro and Kayu Aro Barat. Since the end of the conflict between communities that engaged the Javanese and the indigenous 
Kerinci in early 2000s, the community resided in the sub-district of Gunung Tujuh including in Pelompek Village began to shift the cinnamon plantations to horticulture farming. Figure 9 shows one of the activities for potatoes loading using a truck in Pelompek Village.

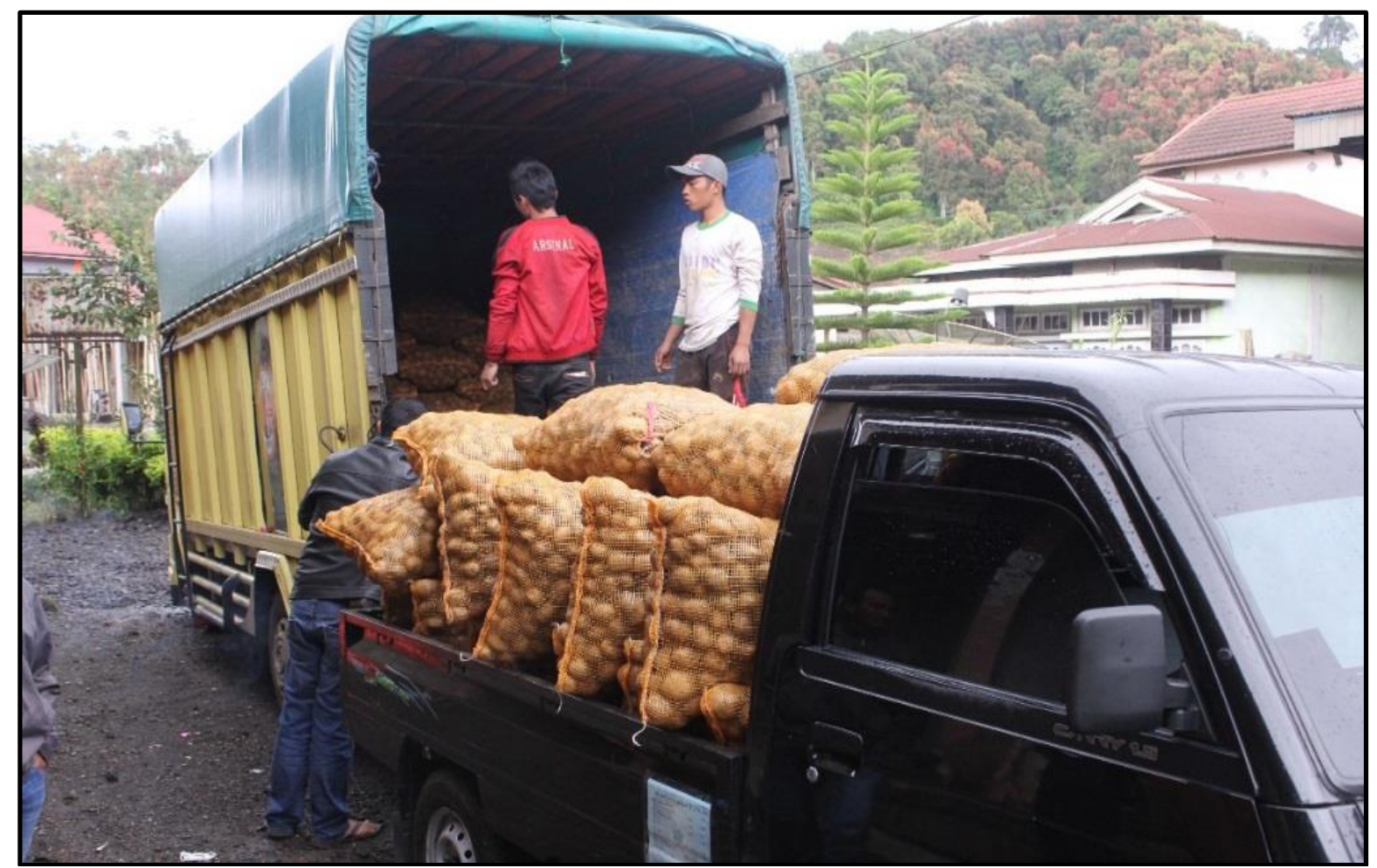

Source: Author's photo

Picture 9 Loading potatoes as part of the farming activities in Pelompek Village

During the early days of 1998 reformation in Indonesia, a horizontal conflict occurred in the northern region between the ethnic Javanese population and the community that claims to be the original tribes of Kerinci. The bloody conflict between the communities caused the loss of many lives, as well as many injuries. Fortunately, the horizontal conflict did not last long and both sides were able to reconcile. A claim of ownership of the land and the economic gap between expatriate communities (Javanese) and local communities (indigenous Kerinci and Minangkabau) triggered the conflict. Furthermore, a significant driver behind the conflict was the differences in the level of social welfare between the two groups of people. The Javanese communities were viewed as more successful and richer than the native communities of Kerinci, who were relatively poor. This problem got progressively worse before the conflict finally resulted due to provocation by a third party, which later elevated the issue of land authority for the area. According to some of the respondents in the present investigation, the root of the problem was a result of differences 
in livelihoods, where the Javanese community worked primarily as laborers in the stateowned tea plantations, (Perseroan Terbatas Perkebunan Nusantara VI/PTPN VI), as well as farming their own vegetables, potatoes, chilies, coffee and cassava; these farming endeavors were done as a means of maintaining and improving their lives. The cultivation land was owned by state-owned tea plantation (PTPN VI) and was rented by the farmers. In practice, commodity farming takes place over a relatively short period of time, e.g., 3-4 months on average. Communities with members holding two jobs, i.e., tea plantation laborers as tea pickers mostly and another activity as subsistence farmers earn greater incomes. Therefore, many of the migrants possessed a house and motor vehicles, among other material possessions, which contrasted significantly with the conditions of the Kerinci natives. Around this time, the members of the native communities, frequently living around Gunung Tujuh, relied heavily on cinnamon plantations. The harvest period for cinnamon is relatively longer than for other commodities, typically between 6 and 10 years. In addition, the price and demand for cinnamon is greatly dependent on the national market. At the national level, the economic and monetary crisis, especially in 1998, influenced both prices and demand for cinnamon, which caused the cinnamon growing communities in Gunung Tujuh to prosper less than the communities in Kayu Aro. The conflict later increased to encompass issues related to the authority of agricultural land and crops belonging to the communities of Kayu Aro. The conflict culminated in the seizure of the agricultural land and the expulsion of the people of Javanese ethnicity, accompanied by the bloody horizontal conflict.

\subsubsection{The change in cultivation patterns regarding farming practices, horizontal conflicts shifted into vertical conflicts over the Natural Resources Authority}

Post-horizontal conflict, there was a shift in the pattern of production efforts within the community of Gunung Tujuh, where the local residents eventually followed the pattern of the Kayu Aro communities, ultimately growing vegetables and other commodities. Currently, many farmers cultivate various vegetables such as cauliflowers, sweet potatoes, potatoes and chilies in the sub-district of Gunung Tujuh. Tilled land was once overgrown with cinnamon, but is now commonly cropped with a multitude of commodity crops. Moreover, cultivation land has entered the KSNP region. The existence of agricultural land and plantations which use conservation areas within KSNP were among the main triggers for the conflict between the community and the KSNP managers. However, other factors were also at work, such as societal dislikes for the rule of laws and the KSNP approach, which is considered to go against the established agreements. 
Community farmland has spread into the conservation areas due to communities not being involved with the KSNP management; for example, when a survey was conducted or a boundary was determined between conservation areas and land belonging to the community. The determination of the boundaries when one area is established as a protected area or conservation is a common problem that frequently happens in Indonesia. Most of the land boundaries for residential and agricultural land areas in Lindung Jaya and Pelompek directly border the conservation areas. Therefore, many cases exist where agricultural land was extended to include land that belongs to the KSNP conservation area and land that belongs to local villagers. Unfortunately, no exact numbers have been recorded by the District Forestry and Plantation Office of Kerinci Regency (Dinas Kehutanan dan Perkebunan Kabupaten Kerinci) with regards to land extension, so it is difficult to determine the degree to which this has happened. However, the KSNP authority has detailed reports which will be discussed later.

With regard to the functions of conserved forest and zoning systems, most of the local people know that the forests in the conservation areas function to maintain the sustainability of biodiversity, serve as a retaining wall, provide water sources and prevent landslides. However, not many people realize that the zoning system applies within the area of KSNP. This ignorance is a primary cause for communities utilizing conservation land and entering into areas such as the jungle and core zones. The encroachment conditions become more complex due to the existence of stakes or delimiters that are sometimes unknown to the public. Purposeful encroachers intentionally remove or shift these stakes, which are generally not the case for local community members. Based on empirical studies and interviews, however, it has been determined that some farmers have intentionally removed the stakes in order to utilize land as if it belongs to them. Removals of the stakes are both known and unknown by the officers. 

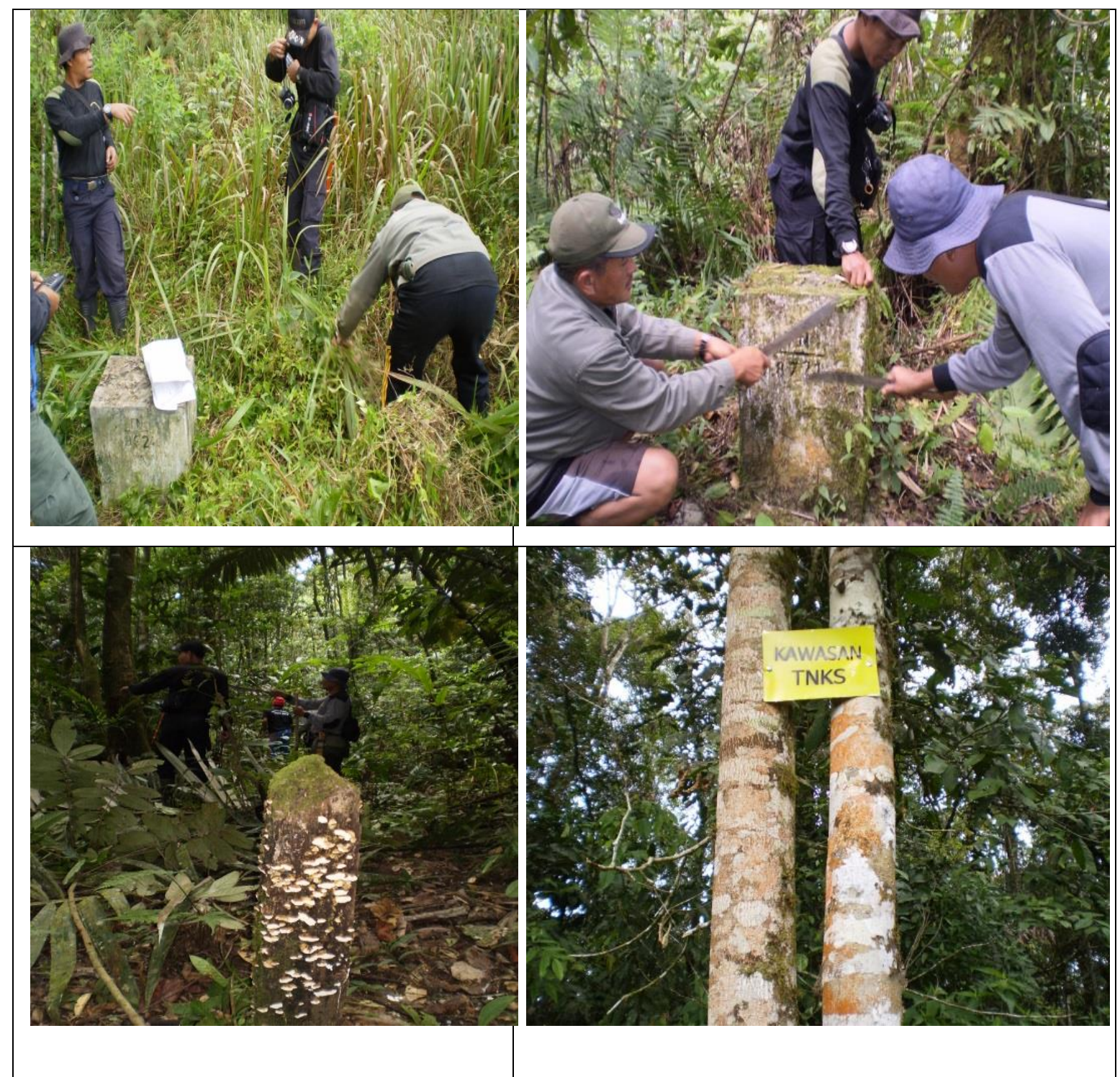

Source: The KSNP authority's photos, 2014

Picture 10 Types of the KSNP (TNKS) stakes

The KSNP parties have utilized stakes to serve as a border between protected land and land that belongs to residents. Additionally, The KSNP authority also use streams, hill slopes and trees as a delimiter. However, many local people often violate these borders. In addition to the zoning system, as well as the ignorance of stake boundaries, the local people commonly view the forest as a gift from God and therefore assume that they can use the forests for their survival and livelihoods.

KSNP, assisted by the local government and the Indonesian National Armed Forces, has been introducing various approaches with the anticipation of resolving the issue. Among them are socialization, regular meetings, supplying assistance and planting trees in deforested sites; these activities are often performed together with the community. The 
purpose of these activities is to get communities to leave their farming land. However, these efforts have always resulted in failure. It is generally difficult to provide strong evidence that land belongs to the communities, although local people commonly argue that they maintain rights to land, even after it is designated as a conservation area, because the land belonged to their ancestors. The societies cannot be judged to be unaware of the damage to the environment or environmental conservation as suggested by the manager or the regional NGO, local government or the KSNP manager, but the public especially farmers contended that a suggestion is not enough to stop the encroachment of the land area. According to the respondents, a suggestion must be accompanied by a tangible aid pattern to farmers. Thus far, assistance programs have been established, but the programs are rare and are not generally synchronized with the needs of farmers. Communities view the programs held by local government or the KSNP manager as not being on target simply as ceremonial activities from the concerned parties.

"'Community members who have already encroached on the conservation area commonly desire attention from the government because they are given seeds, fertilizers and cows; however, they are then required to leave the conservation area'” (Respondent 16, 65 years old, farmer).

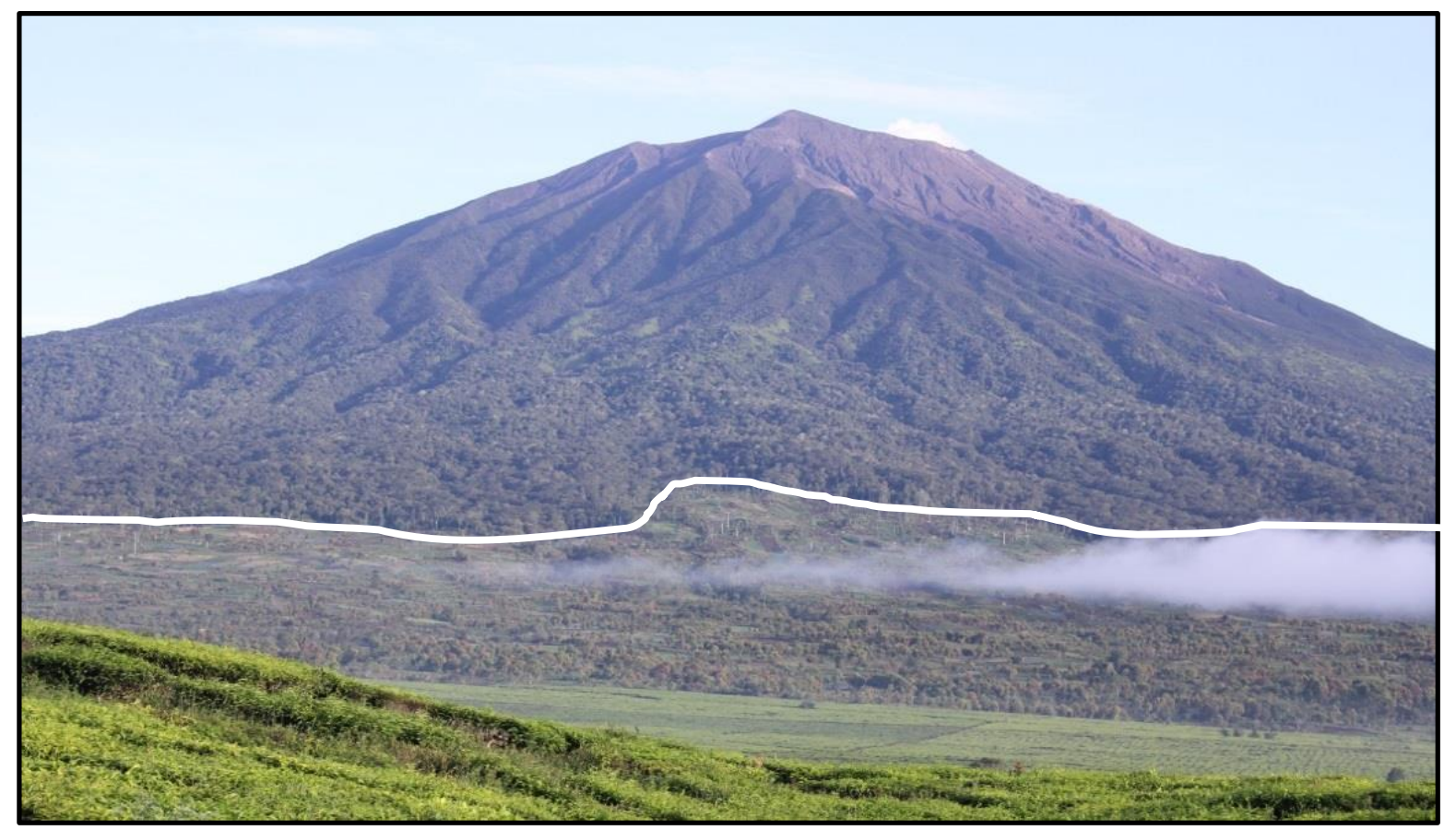

Source: Author's photo

Picture 11 Encroachment area on the slopes of Mount Kerinci (white line) caused by local people's cultivation activities 
Moreover, there is also some degree of awareness amongst local residents who realize that their agricultural activities are illegal and violate the laws within the KSNP area, for example, on the slopes of Mount Kerinci and Gunung Tujuh region. However, the public views these activities as a method of sustaining life and improving their economic wellbeing. The local communities living the encroachment area cannot accept the accusations that they are encroachers or farmers who are cultivating the agricultural land in the conservation area. It means that local people cannot be entirely attributed as encroachers to the villagers around the encroachment area. For example, communities in the village of Gunung Tujuh consider that people from outside the village also carry out some encroachments in the area of the conservation. Hence, there should be a distinction between the local communities with people from outside the related village. This is important with respect to the authority of the arable land area. That is, according to some sources, the managers of KSNP simply see members of the population without knowing if they actually come from the community, hence the related villagers are accused of being environmental destroyers. On the contrary, most farmers who undertake agricultural cultivation come from outside of the village and have control over far greater land areas. Unfortunately, there is no official record to show the total number of people and the total arable land area. Difficulties in identifying encroachers and their land increase due to the difficulty of approaching encroaching farmers. In addition, officers of KSNP are not very likely to ensure location security. Another factor in this problem is community members who are asked to leave the area and then become hostile and defensive towards the officers of KSNP.

\subsubsection{Conservation areas are still polemic for local people}

From the time that the Kerinci area was designated as part of KSNP, the territories of Gunung Kerinci and Gunung Tujuh area have also been directly included as part of the conservation area. Up to now, though, the communities have been aware of and have accepted the conservation area as part of their life, but they are still not satisfied with the concept of authority and land management. Biodiversity owned by KSNP serves as a compelling reason to separate the activities of local residents from the forest. The local communities consider that the officer who manages KSNP does not regard the existence of the communities that existed before KSNP was designated as conservation areas. Therefore, conflicts occur related to land ownership and land use, starting with governments and organizations viewing local populations as destroyers of the environment and the encroachers of land that is protected by the state. Respondents regret any instances where 
park managers and/or government officials suggest that farmers are purposefully taking part in illegal activities. However, local people have been always blamed for not obeying agreements and being stubborn when they are told to leave conservation areas.

\subsection{Perceptions and interactions of the people in Lempur Tengah and Sanggaran} Agung

The villages of Lempur Tengah and Sanggaran Agung are located in the southern part of Kerinci Regency. The two villages are quite unique and are strategically located because the area is adjacent to the regency's iconic attractions, namely Lake Kerinci and Gunung Raya which contain a number of unique lakes and historical-valuable places. The village of Lempur Tengah administratively belongs to the sub-district of Gunung Raya, while the village of Sanggaran Agung belongs to the sub-district of Danau Kerinci. Geographically, the two villages are not directly adjoining, with a distance between one another of approximately $25 \mathrm{~km}$, which would take 30 minutes by motorcycle or car to reach one village from the other. However, there are many similarities between these two villages; in addition to their respective territories having indigenous forests in which are adjoined to the KSNP area, $28 \%$ of the population in each village are natives of Kerinci.

Both villages are historically viewed as old villages, with a long history of settlement, within Kerinci Regency. Hence, the communities obey the customary laws, as well as the cultural traditions that have long been present in peoples' daily lives. In these villages, the original custom homes of Kerinci can be seen and there is historical evidence that indicates that communities have populated the Kerinci area for hundreds of years. A few details can help to distinguish between these two villages, primarily, variations regarding the borders between the settlements of the communities and the KSNP area. Lempur Tengah Village is a residential area that directly borders with the KSNP area, while the residential Sanggaran Agung is next to a state-owned forest and a community-owned forest, as well as the forests of indigenous people; the state owned and indigenous owned forests directly border to the KSNP area. Therefore, if there are conflicts related to access and ownership of land and property, then the conflict situation is primarily between the local communities and outside parties. State owned forest is a forest area which is managed by local government. 


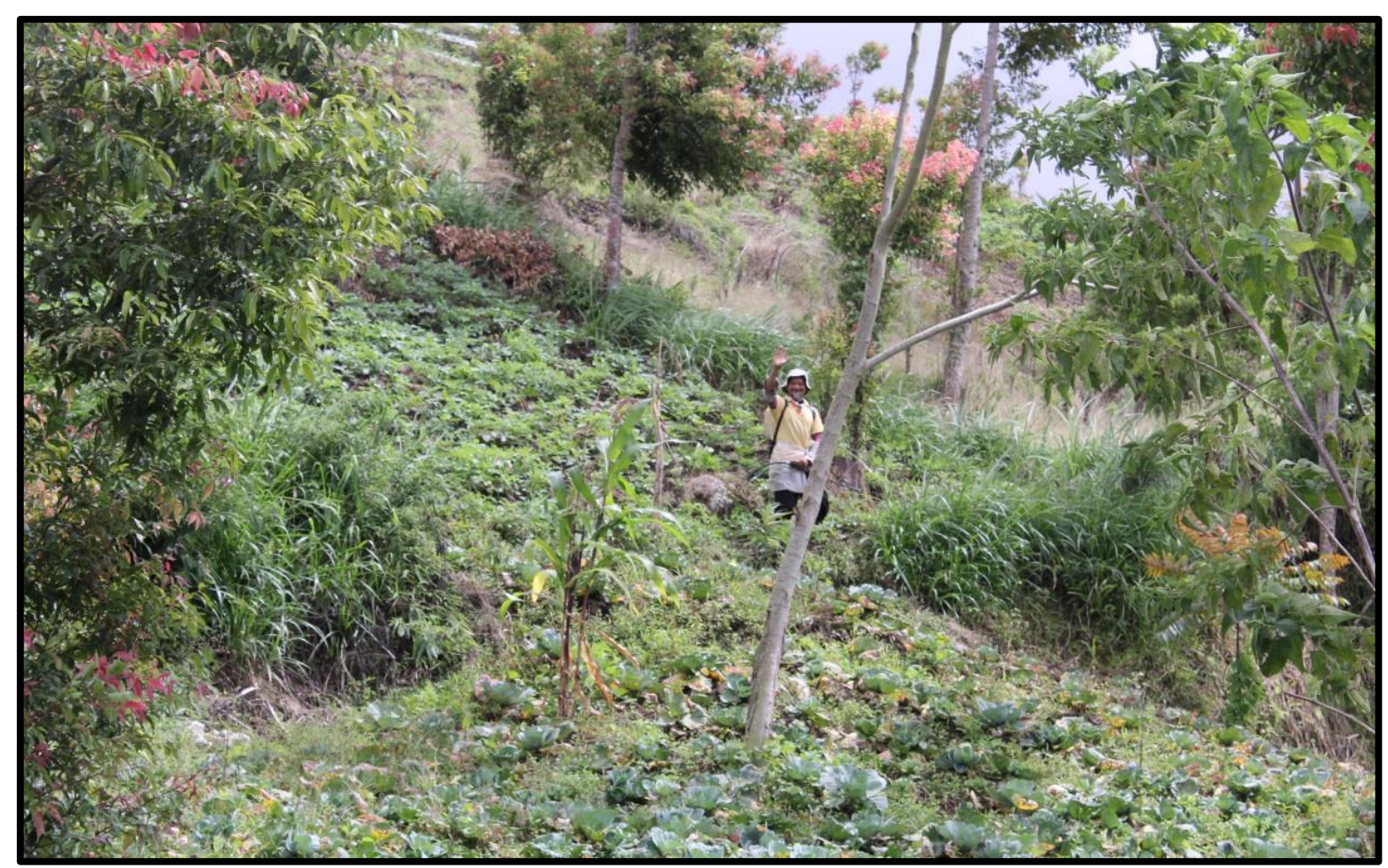

Source: Author's photo

Picture 12 The horticulture-based crops around the cinnamon area

From ancient time, the Kerinci valley has become a known production area for cinnamon. Currently, a great amount of cinnamon can be found in the villages of Lempur Tengah and Sanggaran Agung in the community's fields, the state forest and in the indigenous forests, while the management of these fields is given to the local community. The main livelihood of the people in these villages are farmers with annual crops and rice farming, with the two communities relying heavily on perennials and annual plants such as cinnamon, cloves and coffee. Communities cultivate horticulture and vegetable among young cinnamon. If the cinnamon plant is already high enough and has lush leaves, then the intercropping systems will not be continued because it is not productive anymore.

Nevertheless other horticulture-based crops can also be found in the area. The communities commonly plant their fields with potatoes, chilies, cabbages and other vegetables. The forests and sloped-hillsides are frequently planted with perennials and other crops. Various types of paddy rice are grown in Kerinci Regency, with great demand from traditional markets in Jambi Province, as well as some of the surrounding provinces such as West Sumatra, Riau and South Sumatra. 


\subsubsection{Customary forest and boundaries}

Until now, the existence of the indigenous forest both in and adjacent to KSNP in the village of Lempur Tengah has been a source of dispute between local communities and the managers of KSNP. The trigger issues were related to management rights and boundaries. Local communities have a good understanding of the differences between the people's forest, indigenous forests and conservation forests, along with regulations. Moreover, Local community has demanded to be granted the management rights over the conservation area since the forests were designated as being a part of the KSNP conservation area. Based on respondent interviews, it has been determined that villagers generally better understand the territories and boundaries of indigenous forests than the borders of the protected forest in KSNP. Knowledge related to the boundary of customary forest is very closely related to the rules set in the customary law regulating indigenous people's rights. The utilization of indigenous forests refers to the customary rule that customs and community figures are involved in any usage of the forest area. The procedure and the management of the utilization of land are more clearly understood in villages that have customary laws, as is the case in the village of Lempur Tengah.

'For the field area, farmers know the standard that has been set by the government. The knowledge is also associated with the presence of indigenous forests that can be used by the local community as long as they comply with the established customs. The Kerinci community manages the indigenous forest; those who violate the rules of the indigenous forest area will receive punishment. An example of a commonly used punishment is the expulsion of a person who violates regulation; they will also be taken to or reported to the officer of KSNP to receive punishment from them. As an example from two months ago, two original residents of Palembang were kicked out of the communities because they used the indigenous forest without the permission of the depati or the people of Kerinci that are in charge of managing the indigenous forest. We hope that when we cooperate with KSNP, we can be involved as a partner. Hence, there is recognition that we protect forest that we manage together', (Respondent 32, community leader of Lempur Village).

The public currently has the perception that the KSNP party is unceasing in dictating rules that prohibit the use of protected forest areas without providing solutions that benefit 
both parties, this is particularly true for the people of Lempur Tengah. In the village, most of the agricultural and settlement land areas are adjacent to KSNP. The local community also claims that parts of the KSNP border are the communities' settlements and they deserve to have the management rights of the area due to the customary law. This problem originated from the determination of the national park's borders, in which the community felt that they were not involved in the establishment of the conservation area and were given the understanding that community members are prohibited from entering the area, including for farming purposes. Despite this, most of the villagers of Lempur Tengah actually know the boundary between KSNP and the people's forest. Many even know the zoning border in the area of the national park. A lack of public knowledge regarding the zoning system and boundary designation causes the same problems and demands every year, i.e., the communities demand to manage the outside (buffer zone) of KSNP. The Lempur Tengah village communities will continue to demand permission to manage KSNP because they do not want to be considered as forest encroachers. The community of Lempur is spread across several villages in the district of Gunung Raya, who claims to be one of the oldest sub-ethnic communities in Kerinci. Therefore, they declare that the customary law with respect to the utilization of the forest will always be related to preserving the forests, not damaging them. Moreover, they indicate how the communities in Lempur maintain, utilize and manage the indigenous forests up to now. In the district of Gunung Raya, the community also views the indigenous forest as the people's forest, which is seen as a protected area. They demand preservation of the forests to ensure that the indigenous forest will be given to the next generation. For example, farmers know the stakes for the field that have been set by the local government and the indigenous figures.

Customary forests within Kerinci Regency accumulate to 858.3 hectares. The community of Kerinci manages this indigenous forest. Communities or persons who break the border stakes around the indigenous forest area will receive punishment. Expulsion of violators is a common punishment in this situation. Furthermore, violators will also be reported to the KSNP officers, where they will again be punished. The KSNP officials know that local communities expect some form of assistance as a token of appreciation for the successful capture of forest encroachers. During the interviewing process, one of the young men from Lempur Tengah gave a clear reflection of KSNP valuing the efforts of the local communities to keep encroachers out: 
"As an example, two months ago two original residents of Palembang (the Province of South Sumatra-red) were kicked out of the communities because they used the indigenous forest without the permission of the depati or the people of Kerinci that are in charge of managing the indigenous forest. We hope that when we cooperate with KSNP in managing the protected forest, we can be involved as a partner. Hence, there is recognition that we protect the forests that we manage together. People hope to receive assistance in the form of seeds and fertilizer to develop the agriculture efforts of local communities, with the intended effect being that the community will be more responsible and help KSNP in keeping the protected forest from encroachment. Thus far, KSNP has mostly only given presentations to local communities with respect to forests. However, if there is no mutually beneficial relationship, people tend to feel ignored" (Respondent 53, 35 years old, the Youth of the Village of Lempur Tengah).

Regarding the demands of management and zoning systems, several locations have been heavily favored by the community; these are areas that the community would like to assume management for, particularly Lake Kaco which is part of the KSNP core zone. According to the rules, the area is restricted for everyone. However, the villagers previously thought that they had the right to access the area as they thought that the location was maintained for the sake of the community's economic well-being. The communities believed that accessing these locations would not damage the ecosystem of the conservation areas. They were convinced that the customary laws and formal regulations have always been obeyed by all members of the village, including the treatment to the forest. The communities have ensured the KSNP officials that their activities will actively maintain the sustainability of the national park as they have maintained the sustainability of the indigenous forest. The villagers believe that forests in the region, as well as outside KSNP, do not only contain flora and fauna, but also supernatural beings. In the beliefs of the Lempur Tengah community, it is strictly prohibited to urinate while standing up or to say the word hungry when walking through the forest. Committing either of these acts can trigger the ire of supernatural creatures in the forest, so that the person will be lost in the forest. Another belief is that when one is walking through the forest and sees a tiger, but the tiger does not see the person, then it means that the person has been making many mistakes. Therefore, fasting is for a few days recommended for those who are out of the forest as a 
form of penance. These beliefs still exist in the community as a part of the cultural norms that should be obeyed by everyone, including foreigners and tourists who go into the forest. In fact, the community also believes that the tiger is man's best friend in the forest. According to the community, if someone gets lost in the forest and finds traces of a tiger then it is a good sign for him; furthermore, they say that those who get lost will be able to follow the footsteps of the tiger and make their way back to the village. According to the information from the community respondent, a tiger followed a mother from a house in the village to the market, shocking the community. People did not kill the tiger, but fed him and encouraged the tiger go back into the forest. This incident serves as evidence that local communities will not be actors who damage the environment. Nevertheless, the KSNP managers continue to have concerns that local community will damage the forest if they are given the authority to manage the utilization zone of KSNP. The community maintains that the KSNP party always undermines everything related to forest management in the village of Lempur Tengah. These perceptions can continue to be a trigger for conflicts.

Land use conflicts occur more frequently in the village of Sanggaran Agung, where the community, particularly farmers, demands that the local government pays more attention to the people by administering agricultural aid, primarily fertilizer, so that the community does not have a reason to encroach on the state forest. The villagers of Sanggaran Agung are knowledgeable about the borders of the people's forest and the state's forest. Furthermore, many people also know the whereabouts of KSNP, but many of them do not have a clear definition of the borders of the conservation area and the zoning system of KSNP.

People in the two villages want the local government and the KSNP party to put a stop to lawbreakers, such as wild lumberjacks and forest encroachers on their territory. The communities have gathered evidence that the perpetrators who are frequently caught come from areas outside of the two villages, while some even come from other provinces. For example, the villagers of Lempur Tengah captured encroachment perpetrators in 2013 and, after being punished by the customary law, they were taken to the KSNP officials to be processed according to state law. However, the arrest of forest encroachers by villagers is rarely appreciated by the KSNP party.

People of the two villages inquire that the history of the Kerinci region is never separated from the presence of forests. The public know that their ancestors have been present in the area long before the existence of indigenous forests and KSNP. Surrounding forests are the souls of the Kerinci community. Kerinci is frequently taken into account in the trading community as a substantial producer of cinnamon, due to the abundance of 
cinnamon that can be found in the forests and fields belonging to residents in the villages of Lempur Tengah and Sanggaran Agung. In these villages, there are several smaller industries that are producing cinnamon by-products.

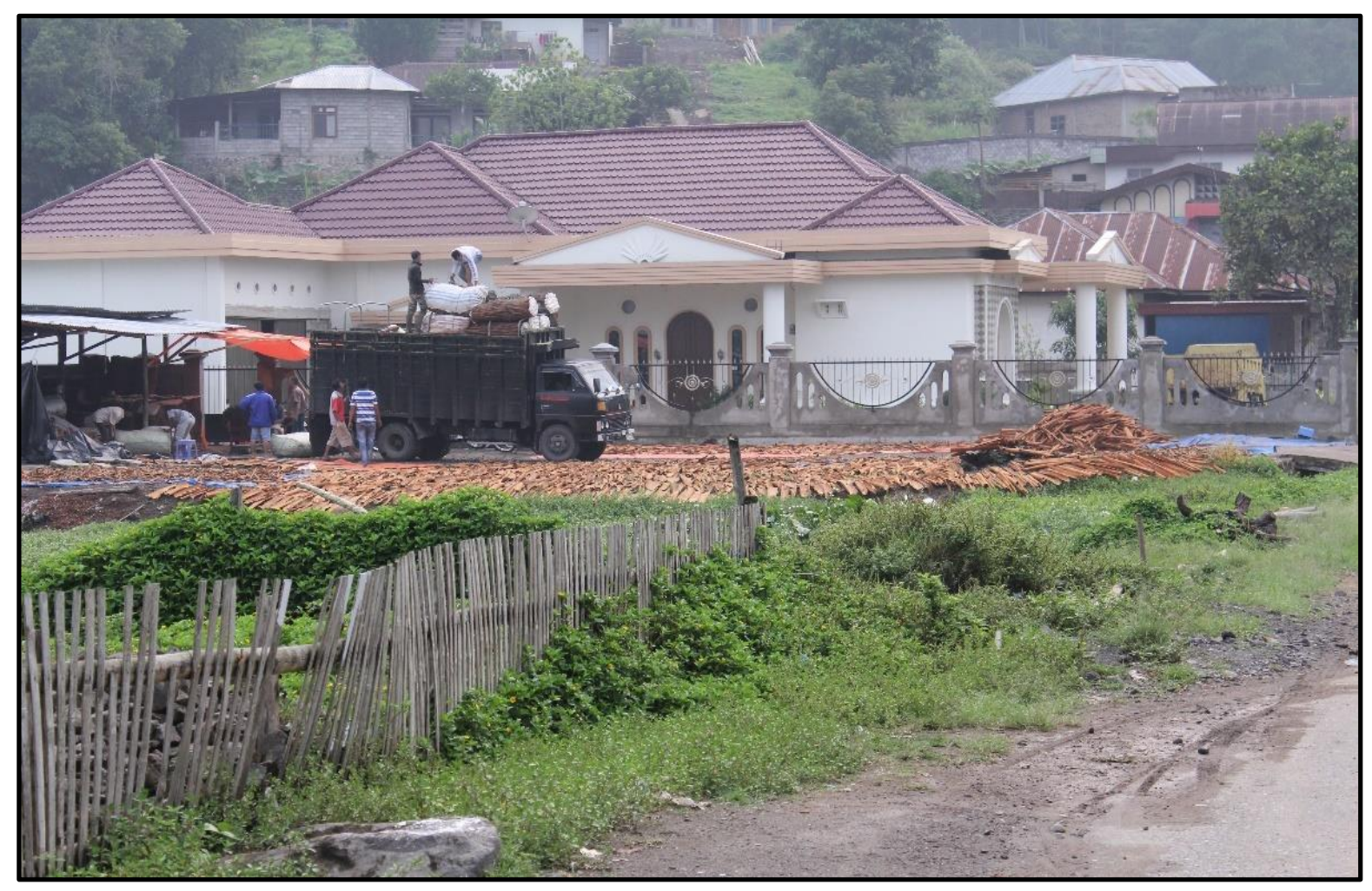

Source: Author's photo

Picture 13 Loading cinnamon as part of agribusiness activities in Lempur Tengah

\subsection{Lessons learned from the empirical study}

Similar to the public perception of forest resources, the public perception of KSNP is built on knowledge about the existence of KSNP, the KSNP boundaries and locations of the local residents' homes and businesses, in addition to the rights of the land authority and management.

\subsubsection{Knowledge about the existence of KSNP}

Empirical studies show that there is a difference in viewpoints of the community on the forest resource with the presence of KSNP in Kerinci Regency. Communities with agricultural activities can utilize forest resources in the people's forests, indigenous forests and the state's forest. These activities are helpful to improve their economic well-being. In general, the viewpoints of the four villages, Lindung Jaya, Gunung Tujuh, Lempur Tengah 
and Sanggaran Agung, are the same, i.e., that the communities are not given the opportunity to actively help and manage KSNP. Moreover, public perception of KSNP is that the area restricts their production activities. The national park is seen as an area that is more concerned with the protection of wildlife, flora and fauna than on the survival of humans. Local communities generally understand the importance of maintaining the sustainability of nature through conservation activities. However, they also recognize the important of human survival. The cynical perception regarding the presence of KSNP is also shared by some of the formal and informal leaders within the communities.

Local communities see that the banning of a range of activities to maintain KSNP area limits the communities from improving their welfare, obtaining a better life and benefiting from the presence of the nature around them. There is even a common expression used by local communities "no single twig in KSNP may be broken, no single animal may die in KSNP, let the men around KSNP starve to death'. This clearly describes how the presence of KSNP is perceived in various layers of society. This perception means that the KSNP management considers plants and animals within the park are more important than humans in the surrounding communities. The public perception of KSNP is influenced by the extent of the area of KSNP in Kerinci Regency that reaches 54\% of the total regency area.

Communities are aware that the KSNP protected area is protected due to its wealth of biological resources. Long before this area was designated as a conservation area, local residents were already wise about maintaining and protecting the wildlife and fauna in the area. The extent of biological resources is even detailed in many traditional songs and dances. Conflicts occur due to the communities' activities having been banned in the conservation area and the KSNP management is not concerned with the population surrounding the national park. This then triggers the engagement in illegal activities, such as the encroachment of the conservation areas and illegal logging. Nevertheless, respondents in the villages of Lempur Tengah and Sanggaran Agung reject the idea that illegal activities involve members of local communities. According to respondents, the perpetrators rarely come from their villages. Furthermore, respondents from Lempur Tengah said that a few weeks before this field-study (2014) was done, the villagers of Lempur Tengah helped the capture of illegal logging perpetrators.

"'A few weeks ago, the national park authorities were assisted by the community of Lempur Tengah to catch people who were cutting down trees in the area of KSNP; the perpetrators confessed that they came from one of the villages in the 
province of South Sumatra', (Respondent 33, 65 years old, villagers of Lempur

Tengah).

Conflicts that arise in the four villages emphasize the management rights of the community in the conservation areas. The community desired the management of the plantation land, as well as the management of tourism in the region. The management desired by the community is the management of the indigenous forests or state forests.

Another viewpoint of the local community is that the KSNP managers undermine not only the cultivation businesses, but also the marketing of agricultural commodities. Some respondents who work as farmers argued that the products of their farming efforts are sometimes damaged on the way to the market due to the distance from their residences to the city. Another difficulty was the long delivery time for agricultural products which lead to diminished quality. An alternative for shortening this route was to open the road that goes through KSNP. However, the managers of KSNP will not allow the opening of a road that divides conservation areas for fear of causing damage to the area.

These difficulties stem from the poor road infrastructure throughout the region. For example, two lanes leading to the city of Padang, West Sumatra pass through the South Pesisir and South Solok regencies. People have proposed for the slight extension of this road in order to better deliver farm products. If issues related to delivery time for agriculture products are not solved, it will continue to negatively affect the economic situation in the region. In terms of local farmers, the economy of the village will die. The welfare of the sub-districts of Kayu Aro and Gunung Tujuh is dependent on farms and agricultural sales. The KSNP managers are very slow to give permission for the opening of roads in the conservation areas, according to public perception. As a result, many communities frequently open their own forest trails. This will eventually lead to vertical conflicts. The community has also asked the local government to help them negotiate with the KSNP party; however, these requests have not been met. Farmers and local communities hope that the local governments can understand the economic situation faced by members of the local community and make efforts to pay better attention to farmers in these areas. Currently, foreign investors from the Netherlands have developed interest in the opportunity to build a cinnamon processing factory so that the local communities are able to process cinnamon by themselves. 


\subsubsection{The KSNP area borders, as well as the settlement and business locations of local residents}

Based on interviews with respondents from Lempur Tengah, most of the Kerinci communities know where the border of their own land meets the indigenous forest, state forest and the KSNP forest. The borders are marked by the use of stakes, rivers, trees and slopes. The KSNP party marks many borders with stakes in an effort to further depict the separation of the KSNP area from other forest areas. Therefore, cases of encroachment and illegal logging conducted by local communities are rarely found. In several instances, forest encroachment perpetrators come from outside the village of Lempur Tengah and, in some cases, even from outside the province of Jambi.

"'Almost all of the residents in the village of Lempur Tengah are farmers or those who till cinnamon. They use their own land or state-owned land intended for business use", (Respondent 1, 75 years old, farmer).

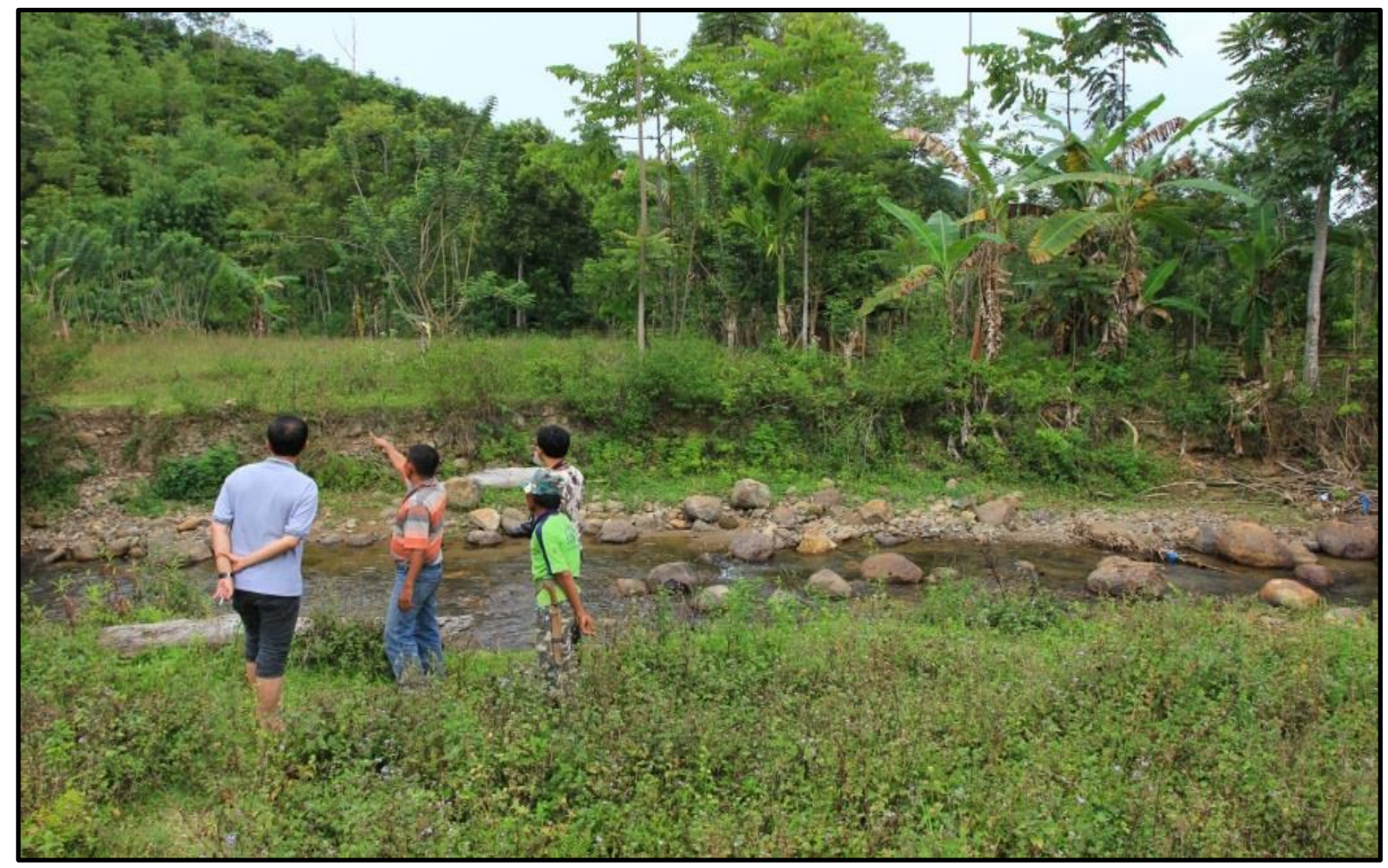

Source: Author's Photo

Picture 14 A farmer showing the borders of the state-owned forest in Sanggaran Agung

It is rarely those from the local community that violate the conservation areas, yet it does happen on occasion. According to several respondents, the community members' understanding of the laws is only related to land use. In fact, by taking even a few tree 
trunks or entering conservation areas without permission, a violation has been committed. However, a different perception of these violations exists between local communities and the KSNP managers; this has often led to difficulties in finding a solution between the two parties. The local people consider the forest to be their hereditary right. In the villages of Lempur Tengah there are several attractive and beautiful lakes that are considered by the community to be gifts from God that can be utilized for the promotion of their well-being. Unfortunately, some of the lakes belong to KSNP, even the favorable Lake Kaco, which is in the core zone within the conservation area.

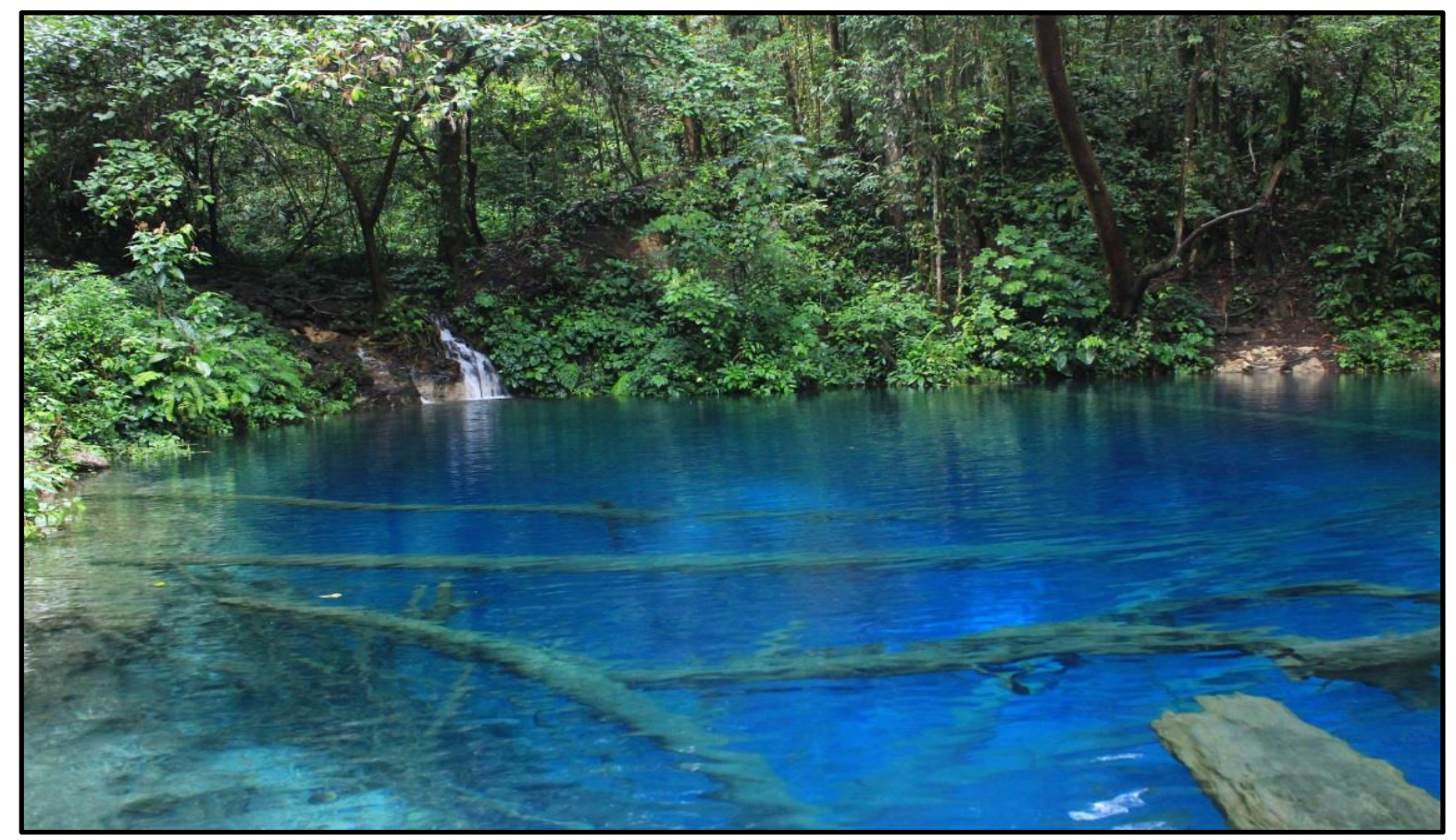

Source: Author's photo

\section{Picture 15 Lake Kaco located in the core zone insight KSNP in Lempur Tengah}

There are three groups of public opinions about the zoning systems of KSNP, i.e., the public either knows or does not know about the system. Those in the first group understand and are able to explain the zoning system; this group often interacts with the management party of KSNP, and includes representatives such as the village head, indigenous leaders and youth leaders. They often attend meetings and serve as messengers for society when speaking with the managers of KSNP. The second group is those who knows the term zoning, but cannot properly explain the zoning system. This group is only able to describe a system of zoning as a delimiter between conservation areas and the land belongs to the community. Moreover, communities in these two groups can understand if they are banned from using conservation land areas. The third group is the community that does not know 
what the term zoning means and cannot explain the zoning system at all. They are only aware of the existence of stakes or borders between the KSNP area and the land that belongs to the local communities. The individuals in this group frequently exceed the borders of their allotted areas when partaking in farming activities. Furthermore, they are unaware of the prohibition. However, there is also the community who knows the borders of the area, but still utilizes it as a field or farming area.

Gardening or tilling is considered to be a hereditary legacy of the livelihood of the community members in Kerinci Regency and has become a community tradition. This view serves as a reason that community members feel they are allowed to use areas within KSNP for farming, leading to many locals violating border restrictions. They think that as the natives of Kerinci Regency, they cannot be prohibited from using land surrounding their residences. Most of them consider the area to be part of their ancestral heritage. Additionally, they feel that the government is fonder of plants and animals than of humans. Furthermore, the utilization of this land is seen merely as a method of survival.

\subsection{Community interactions with the forest resources, environment and KSNP}

In this research, community interactions with forest resources and the environment includes the utilization of natural resources and livelihoods, rights to the land authority and management, as well as the local cultural interactions with the natural environment. People living in areas surrounding KSNP are mostly farmers. Agricultural cultivation and tillage activities refer to the utilization of natural resources that are used as the main source of livelihood for community members. People in Kerinci Regency have long relied on cinnamon as an agricultural commodity, as well as having introduced it to those outside of the area.

\subsubsection{The rights to land authority and management}

Local communities have long been utilizing forest resources in the area. In general, forests within the Kerinci Regency are frequently planted with many cinnamon trees. The trees have long been used as the flagship commodity within Kerinci Regency. Historically, people outside of the region know the area and the community of Kerinci due to the cinnamon trade. Based on field studies, differences between communities in the southern and northern parts of Kerinci can be found in terms of land use; particularly, the tree covers in the southern parts are still very dense and the land is commonly planted with cinnamon. In the northern areas, however, cinnamon can still be found, but it is generally a sign that 
those growing cinnamon in the northern areas have encroached upon the slopes of Mount Kerinci and entered the protected forest because it is not commonly grown in these areas.

Based on information from KSNP, the areas at the foot of Mount Kerinci and around the sub-district of Gunung Tujuh have frequently been encroached by the local communities, with up to 500 ha of protected forests being utilized by the local communities. The officials encounter difficulties when asking residents to stop their encroachment activity due to the limited number of officers and hostile behaviors of the community members. The community does not hesitate to fight physically to defend their fields due to their opinion that the land is their ancestral right.

As previously explained, the indigenous and people's forests in the sub-districts of Gunung Raya and Danau Kerinci are still dominated by cinnamon production. According to respondents, if any land is still available after cutting cinnamon tree, then they will plant that land with cinnamon as well. When the cinnamon tree is still small, a variety of crops and plants will be planted in an effort to develop an intercropping system. Land planted with cinnamon trees are generally in the higher plains or on the hill slopes. While in the lower plains, such as in the communities of Lempur Tengah and Jujun (one of Lempur Tengah Village's neighbor), paddy rice is planted instead. Local people own rice land privately. There is almost no state-owned land, indigenous forests or conservation areas in the lowlands.

Based on empirical studies in the four villages, it is perceived that forests are positioned in a way that makes the KSNP area useful as a natural resource, as well as an energy source, for the entire nation. The local communities, however, view forests as a place to live that should also be utilized. The difference in these perceptions and interests with respect to forests often lead to conflicts. The state uses rules and regulations to frame forests as conservation areas, while local people consider forests to be a gift that should be utilized for the well-being of the community.

On behalf of country-wide interests, many forests throughout Indonesia, including KSNP, have been heavily regulated with a series of laws and regulations that essentially states that the forests are conservation forests and the property of the state. On the one hand, norms, customary laws and customary rights intended to protect forests deserve a role in the management of forests and natural resources, and should not be used carelessly. Local wisdom dictates that local people have been living and working on these lands for hundreds of years and served as the initial protector of these natural resources. However, these customary rights which include rules for proper management of the forests and their 
utilization became invalid when the rules of the state, as well as those specific to the conservation areas, were put into place. History has separated communities' entitlements with respect to access to natural resources which now belong to the state. Based on the empirical study, it is apparent that the state has not made sufficient effort to combine the wants and needs of local communities with the wants and needs of the state, specifically the intent of achieving a sustainable conservation area.

\section{Participant observation from the field study}

During the field survey, the author was fortunate to be able to attend several meetings at the village level that were initiated by the provincial government, the Office of Tourism in the Jambi province, along with several stakeholders. The stakeholders consisted of members of local communities from Lempur Udik and Lempur Tengah, the KSNP staffs, NGOs, experts on tourism and forestry, provincial government staff, as well as two speakers from abroad. Unfortunately, representatives of the local government could not attend because they needed to prepare for the Festival of Lake Kerinci. The local community members were comprised of various representatives, such as the village head, village office staff, youth representatives, religious leaders and traditional leaders, such as the depati. The main topic of these meetings was to find solutions for managing tourism attractions that are located in both the Lempur Tengah Village and KSNP; for example, Lake Kaco and the other beautiful lakes. The local community expected that management of the tourist destinations could be handled by an organization that they established. Desa Adat (Indigenous Village) was used in an effort to convince the KSNP staff. The proposed establishment of the indigenous village was quite reasonable considering that it is an old village with many customs, traditions and norms that govern the relationship between man and nature, as well as general human behavior. However, the local people were aware that they did not have a strong legal hold for their activities. Local people do not want to be stigmatized as environment loggers and be processed as criminals. On the other hand, the author got the impression that the manager of KSNP may have been reluctant to hand over the management of tourist attractions in the national park area to the local community. The staff seemed concerned about 
mismanagement and the destruction of the area's biodiversity. Existing collaborations also caused some problems. For example, a local youth organization cited money $(I D R 150$ thousand $=\$ 15)$ to the tourists who go to Lake Kaco. 


\section{Chapter VI. The Role of Governmental Agencies in Preserving Natural Resources: Evidence from the Empirical Study}

Studies relating to the role of local governments and national agencies regarding the management of forests and conservation areas have given insight into the relationship between regulation implementation of natural resources management and community participation level. This study shows that implementation management cannot be conducted in all of the villages. Although the distances between the villages within Kerinci Regency are close, for example they can all be reached in less than an hour, the behaviors, desires and needs of the individual communities are not similar.

One of the natural resource policies for the region is community-based preservation, intended to increase the participation of local people. This policy has been implemented in recent decades and is considered to be a successful policy. In developing countries, similar community-based natural resource policies are top-down policies which have been successful and are readily accepted by stakeholders. The policy requires community participation to manage natural resources within a region (Selfa, T., Endter-Wada, J., 2008).

Differences in the characteristics of local populations indicate the evolutionary phases that communities go through, a thorough description of this can be found in Chapter 5.The values and norms of local people in Kayu Aro and Gunung Tujuh Villages are greatly influenced by Javanese and Minangkabau immigrants. People in Gunung Tujuh, however, believe that they are the indigenous community of Kerinci. Most of the communities in Lempur Tengah and Sanggaran Agung Villages are characterized by the Kerinci culture, but the influence of other cultures can also be seen in their daily activities. Therefore, their requirements related to the rules and the roles of the local government and local agencies are also different. The majority of the locals in Kayu Aro and Gunung Tujuh, located in the northern region of the Kerinci valley, are farmers who cultivate many horticulture-based crops. While in the southern part of Kerinci, most of the people cultivate cinnamon as a perennial crop. Furthermore, it is necessary to define a community and understand their differences in order to increase participation through formal institutions (Selfa \& EndterWada, 2008). Moreover, it is important for the local government to consider helping to develop a relationship between local communities and natural resources.

This chapter explains community involvement in the regulations of the local government. Furthermore, the chapter also describes how the KSNP authority formulated 
the communities' preferences to reach sustainable development within the national park and to minimize social conflicts. The key success factors of interactions between the local government and the KSNP staff with respect to proper utilization of the natural resources in KSNP in terms of the local economy and politics will also be described in this chapter. This chapter begins with a brief discussion of the forest resource conditions in Indonesia to illustrate the problems with respect to collaboration patterns. Moreover, the perspectives of natural resource management, especially forest resources, is always linked to economic and politic interests of stakeholders; this chapter emphasizes the perspectives of local government and the KSNP staff in terms of managing natural resources and the national park.

The methods for gathering the data used in this research come from a content analysis of policies and the history of the region, in-depth interviews with key respondents, open discussions, focus group discussion (FGD) with the KSNP officials and local government officials. Moreover, the topic of improving public participation in environmental management is also covered in this chapter. In-depth interviews and open discussions were conducted with staff members and leaders of KSNP, as well as with key respondents, such as academics from Bogor Agricultural University, the University of Jambi, the NGO Flora and Fauna Indonesia, as well as Warung Informasi Konservasi (Warsi) in Jambi. The FGD was held at the office of the KSNP office in Sungai Penuh city.

\subsection{Community and public involvement in forest planning according to the perspectives of the local government}

There are four national parks in the province of Jambi: Kerinci Seblat National Park (KSNP), Berbak National Park, Bukit Tiga Puluh National Park and Bukit Dua Belas National Park. These national parks were designated based on the strategic value of the area, with the designation being based on Government Regulation (Peraturan Pemerintah) No. 26 of 2008 as part of the National Spatial Plan. The National Strategic Areas are prioritized spatial areas where significant impacts have been recognized for the national sovereignty of the state, national defense and security, economy, society, culture and/or the environment, this also includes the areas designated as food heritage areas. Kerinci Regency is a district that has an established national park in Jambi Province.

This study investigates the potential of forest resources, including protected forests, production forests, indigenous forests, as well as the participation patterns within these 
forests with respect to plantation crops, water resources and ecotourism. Ecotourism will be further described in Chapter 7.

Regarding the political and economic perspectives related to natural resources, the local government of Kerinci Regency developed the Medium Term Development Plan (Rancangan Pembangunan Jangka Menengah) to be implemented from 2009 to 2014, which further consists of two specific areas: protected forest areas and cultural areas. The main reference of this plan is Law No. 4 of 1982 which is related to the main rules of environmental management. The law states that development process should consider two important aspects of natural preservation: economic activities, specifically those utilized as a source of livelihood, and conservation. However, the environmental protection and economic activities are sometimes contradictory to the other regulations. For that reason, the local government of Kerinci Regency has fully outlined the characteristics of protected and cultivation areas (see Medium Strategic Development Plan, 2009-2014).

\section{(1) Protected area}

A protected area is an area where the main function is to preserve environmental sustainability, specifically related to natural resources and cultural history. The protected areas in Kerinci Regency located in KSNP. The major roles of a national park are to maintain natural ecosystems, preserve biodiversity and germplasm, maintain ecological balance and water systems, and prevent flooding, erosion and landslides which often occur in hilly regions. The protected area should not be used for agricultural production and human activities that may damage the environment. Protected areas can be divided into four groups: a) an area that protects the subordinate areas including protected forests, peat and water catchment areas, b) an area of local protection, including rivers, areas around lakes, reservoirs, springs , c) an area of natural reserves consisting of natural conservation, national parks, forest parks and natural tourism parks, as well as regions with strong cultural and scientific importance, and d) an area which has high potential for natural disasters.

\section{(2) Cultivation area}

A cultivation area is an area outside of protected areas with the main function of serving as a place for cultivation to take place that considers the conditions or potential for natural, human and man-made resources to be used for economic and human benefits. Cultivation areas can further be divided into five classifications: a) an area of limited production forest, an area of permanent production forest and an area of conversion production forest, b) a 
farming area covering an area for wetland food crops, dryland food crops, annual crops or plantations, livestock, and fisheries, c) mining area, d) tourism region, and e) settlement areas. Most cultivation areas are community-based production forests or Hutan Produksi Kemasyarakatan (HPK) which is largely utilized for Casiavera (cinnamon) production. More than $60 \%$ of HPK in Kerinci Regency has been converted to be utilized for farming and plantations, although some of the land has been abandoned. Reforestation efforts for HPK areas have been done so that some locations will be used for agroforestry activities. The utilization of forestry products, such as logs and rattan, needs to be addressed and controlled for with regards to ensuring the sustainability of activities to prevent forest damage and to maintain healthy environmental ecosystems.

Within Kerinci Regency, protected areas dominate, with the total protected area of KSNP amounting to 215,000 hectares, or $51.19 \%$, of Kerinci Regency. This area cannot be utilized by local communities or the local government, who are encouraged to cooperate with the KSNP office which is located in Sungai Penuh city. Table 21 shows the classification of forest areas within Kerinci Regency according to forest functions as detailed in the Kerinci Spatial Plan. Furthermore, the total area of forests, as well as the classification of these forests in Jambi Province (in accordance with the Forest Land Use Agreement/Tata Guna Hutan Kesepakatan (TGHK) and Spatial Plan are listed in Table 22.

Table 21 Classification of forest areas in Kerinci Regency

\begin{tabular}{|l|c|}
\hline Type of forest & Area (Hectares) \\
\hline Property rights forests & $5,000,00$ \\
\hline Indigenous forests & $1,820.11$ \\
\hline Conservation forest (KSNP) & $191,822,00$ \\
\hline Community Based Participation Pattern & $28,665,00$ \\
\hline Total & $\mathbf{2 2 7 , 2 3 8 , 5 0}$ \\
\hline
\end{tabular}

Source: Forestry and Plantation Office of the Kerinci Regency, 2011 
Table 22 Classification of forest areas in Jambi Province

\begin{tabular}{|c|l|c|}
\hline \multicolumn{1}{|c|}{ Function of forest } & Area (Hectares) \\
\hline 1. & Areas of preservation and natural conservation & 30,400 \\
& a. Wildlife sanctuary & 645,290 \\
& b. National park & 430 \\
\hline 2. & c. Natural tourism & 191,300 \\
\hline 3. & Limited production forest & 340,700 \\
\hline 4. & Permanent production forest & 971,490 \\
\hline & Total & $\mathbf{2 , 1 7 9 , 4 4 0}$ \\
\hline
\end{tabular}

Source: Forestry and Plantation Office of Kerinci Regency, 2011

There are some notable differences in the forest sizes in Kerinci Regency and Jambi Province (Tables 21 and 22). More than 50\% of the total area in Kerinci Regency is classified as a conservation area, while a large portion of the area in Jambi Province is designated as permanent and limited production forests. Therefore, it is apparent that the majority of land within Kerinci Regency is reserved for conservation activities.

A conservation area in the form of a national park is an area that is protected due to the extensive diversity found in the area, specifically with regards to flora and fauna, ecosystems, natural phenomena, germplasm used to support scientific research, and natural preservation. Therefore, the remaining forest area that is not classified as a conservation area, in Kerinci Regency has been designated in ways that support local economic development, minimize illegal usage and preserve natural conservation. Table 23 shows the variation in land use within Kerinci Regency, including Kerinci Seblat National Park.

Table 23 Land use in Kerinci Regency in 2009

\begin{tabular}{|c|l|c|c|}
\hline No & \multicolumn{1}{|c|}{ Land use } & Area (Ha) & Percentage \%) \\
\hline 1 & Kerinci Seblat National Park & $191,819.00$ & 59,42 \\
\hline 2 & Production forest & $28,665.00$ & 8,88 \\
\hline 3 & Indigenous forest & 801.84 & 0,25 \\
\hline 4 & Sugar plantation & 1,440 & 0,45 \\
\hline 5 & Tea plantation & 3,055 & 0,95 \\
\hline
\end{tabular}




\begin{tabular}{|c|l|c|c|}
\hline 6 & Wet land & 12,000 & 3,72 \\
\hline 7 & Dry land & 42,444 & 13,15 \\
\hline 8 & Perennial crops & 35,271 & 10,93 \\
\hline 9 & Settlement area & 2,045 & 0,61 \\
\hline 10 & Swamp & 52 & 0,02 \\
\hline 11 & Other uses & 5,243 & 1,62 \\
\hline \multicolumn{2}{|c|}{ Total } & 322,842 & 100 \\
\hline
\end{tabular}

Source: Government of Kerinci Regency, 2012

The largest area in Kerinci Regency is KSNP that accounts for about $59.42 \%$ of the land in the regency. Land used for other purposes such as indigenous forests, sugar plantations and settlement areas utilize only a very small area, less than $1 \%$. However, this miniscule amount of land serves as the primary area for the local government to generate income. According to one of the survey respondents, the staff in the Regional Development Planning Board of Kerinci Regency, stated that having only limited areas intended for improving the livelihood of the population can lead to illegal logging, encroachment onto KSNP lands, forest fires and global warming in the long run.

', The local government assumes that the annual increases in illegal logging and land encroachment activities are influenced by the communities' increasing needs. The local communities' activities, which are not in accordance with the law, are relatively difficult to put a stop to" (Respondent 59, Staff member at the Regional Development Planning Board of Kerinci Regency).

The other impact of limited land availability is the lack of a steady wood supply, which is greatly influenced by the increasing demand for wood as a home building material due to the increase in the local populations' livelihood. Scarcity of wood is a common occurrence in Kerinci Regency. The key respondent said that the local government, as well as the local people, held the opinion that the KSNP officials do not allow for the utilization of the forest in KSNP. However, members of the community indicated that the KSNP staff could not prevent large forest encroachers due to a lack of power.

In this regard, illegal logging has heavily influenced the reduced number of forests. In the long-term, fewer forests lead to natural disasters such as landslides, flooding and global warming. The local government has proposed a strategic plan to apply agriculturally intensive land-use patterns in an effort to control the utilization of natural resources, restrict farming activities around forest areas, develop a buffer zone between forest and cultivation 
areas, reduce land degradation, improve land capacity and facilitate the cooperation between regions in the upstream and downstream ends of watershed management efforts in KSNP. The proposed strategies are outlined in the Long-Term Spatial Plan of Kerinci Regency intended for implementation between 2012 and 2032.

\subsubsection{Community participation in the management of the agroforestry system according to local regulation for forest governance}

In order to manage the land use in KSNP, the office of Forestry and Plantation has published and implemented the Production Forest of Community Based Participation Pattern/Hutan Produksi Pola Partisipasi Masyarakat (HP3M) and Indigenous forest in 2012. The objectives of the program are to improve the livelihoods of local communities, conserve ecosystems, preserve the ecological balance and water systems, as well as the catchment area, and prevent flooding, erosion and landslides in hilly areas. The HP3M programs utilize the buffer zone between the cultivation and conservation areas of KSNP. Casiavera (cinnamon) is commonly cultivated in the area. The total land area amounts to 28,665 ha; unfortunately, more than $60 \%$ of this land has been converted for farming and plantation usage for the local people, or has been completely abandoned. HP3M is spread out across several of the region's districts, including Gunung Raya, Danau Kerinci, Kayu Aro and Gunung Tujuh. Map 4 shows the locations of the HP3M area within Kerinci Regency as of 2013. 


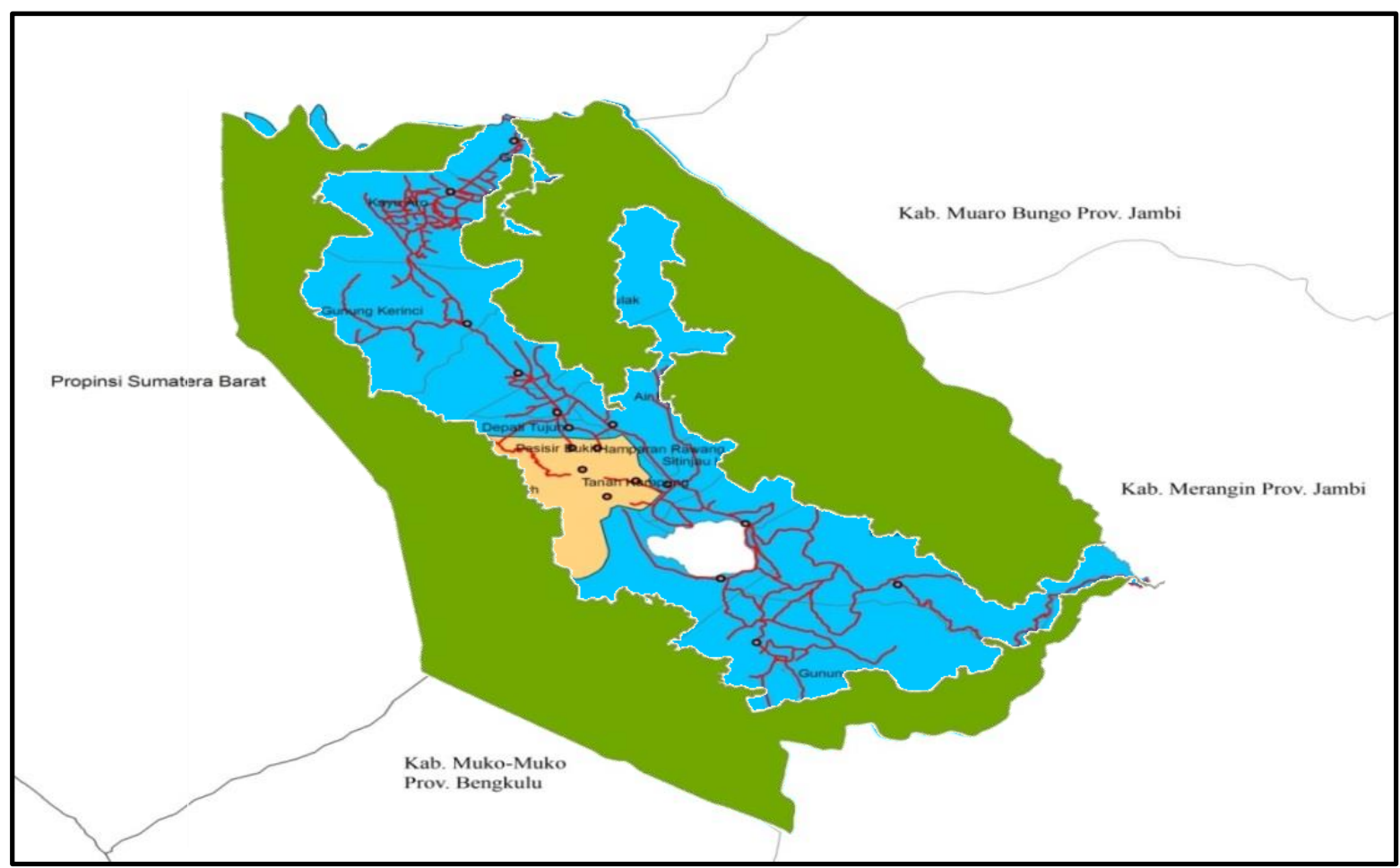

Source: Office of Forestry and Plantation of Kerinci Regency, 2013

\section{Map 4 Location of the production forest in the community based participation pattern (blue) in Kerinci Regency in 2013}

The local government actively monitors the area and conducts various land-use approaches in accordance with the customary forest rights / Hak Hutan Adat (HHA). Some villages in Kerinci Regency are old villages which have customary laws such as forest indigenous right (hak ulayat) and customary forest rights in place to help manage the forest area as a livelihood source. Such laws were established based on the communities' awareness regarding the importance of sustainability, harmony and balance of the ecosystems. Rights to the area do not belong to the state, but rather to the indigenous community. The objectives of forest indigenous right in Kerinci Regency are sustainability, harmony and balance for social, environmental and cultural aspects. Management and monitoring of the forests are conducted by local institutions that have been established in each location and operate in accordance with the rules that have been defined by the institution. Management and monitoring activities include surveillance, maintenance, supervision, controlling and empowerment of the forest. The activity approaches are put in place by the village forum through traditional forum such as Kenduri Sko, indigenous meetings and religious activities. The total area designated as indigenous forests in Kerinci Regency is $1,820.14$ ha, with the area for each forest being described in Table 24 . 
Table 24 Definite customary forests in Kerinci Regency

\begin{tabular}{|c|l|c|l|l|}
\hline No & \multicolumn{1}{|c|}{ Name } & $\begin{array}{l}\text { Area } \\
(\text { Ha) }\end{array}$ & \multicolumn{1}{|c|}{ Location } & \multicolumn{1}{c|}{ Law } \\
\hline 1 & Temedak & 23 & $\begin{array}{l}\text { Keluru, Kec. } \\
\text { Keliling Danau }\end{array}$ & $\begin{array}{l}\text { Decree of Kerinci Regent } \\
\text { No. 176/1992 }\end{array}$ \\
\hline 2 & $\begin{array}{l}\text { Nenek Limo Hiang, } \\
\text { Kenek Empat Betung } \\
\text { Kuning and Muaro Air } \\
\text { Duo Kecamatan Stinjau } \\
\text { Laut. }\end{array}$ & 858.53 & $\begin{array}{l}\text { Hiang, Sitinjau } \\
\text { Laut }\end{array}$ & $\begin{array}{l}\text { Decree of Kerinci Regent } \\
\text { TK II Kerinci No. 226 } \\
\text { Year 1993 }\end{array}$ \\
\hline 3 & $\begin{array}{l}\text { Lekuk 50 Tumbi } \\
\text { Bukit Tinggai }\end{array}$ & 41.27 & $\begin{array}{l}\text { Kec. Air Hangat } \\
\text { Timur }\end{array}$ & $\begin{array}{l}\text { Lecree of Kerinci Regent } \\
\text { Gunung Raya } \\
\text { No. 522.21/Kep. 437/2011 } \\
\text { No. 96/ 1994. } \\
\text { May1994 }\end{array}$ \\
\hline 5 & $\begin{array}{l}\text { Bukit Sembahyang and } \\
\text { Padun Gelanggang }\end{array}$ & 39.04 & $\begin{array}{l}\text { Air Terjun, Kec. } \\
\text { Siulak }\end{array}$ & $\begin{array}{l}\text { Decree of Kerinci Regent } \\
\text { No. 522.21/Kep. 435/2011 }\end{array}$ \\
\hline 6 & $\begin{array}{l}\text { Hutan Hak Adat Tigo } \\
\text { Luhah Kemantan }\end{array}$ & 426 & Kemantan & $\begin{array}{l}\text { Decree of Kerinci Regent } \\
\text { No. 522.21/Kep.373/2013 }\end{array}$ \\
\hline 7 & $\begin{array}{l}\text { Hutan Hak Adat Tigo } \\
\text { Luhah Permenti Pungut } \\
\text { Mudik }\end{array}$ & 152 & Pungut Mudik & $\begin{array}{l}\text { Decree of Kerinci Regent } \\
\text { No. 522.21/KEP.181/2013 }\end{array}$ \\
\hline
\end{tabular}

Source: Office of Forestry and Plantation of Kerinci Regency, 2013

The Rights of Indigenous Forest have been defined by the law since the early 1990s, although the forest has been in existence and established in surrounding communities for several hundred years. The majority of the indigenous forest is planted with annual crops such as cinnamon and coffee. The forest in the village of Lempur Tengah Lekuk 50 Tumbi is known as the largest forest in which the local community has maintained and achieved sustainability. The indigenous forest in Lempur Tengah has an area of 858.3 ha and was defined by the Decree of Kerinci Regency No.96/1994 on May 10 ${ }^{\text {th }}, 1994$ (Map 5). 


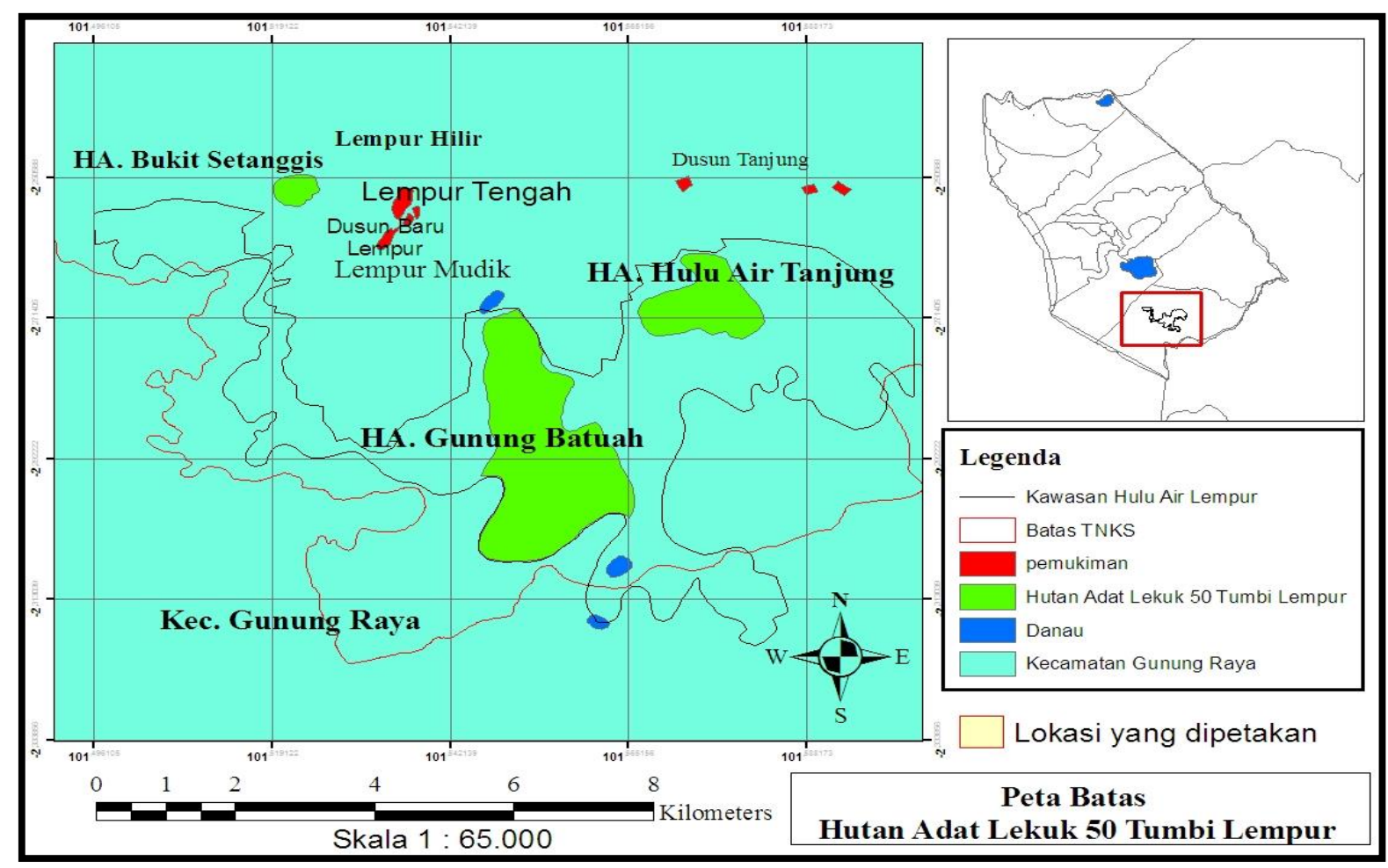

Source: Office of Forestry and Plantation of Kerinci Regency, 2013

\section{Map 5 Location of indigenous forest of Lekuk 50 Tumbi}

Currently, people in Lempur Tengah village are proposing that the village is also to be defined as an indigenous village, along with the neighboring communities, particularly the sub-districts of Gunung Raya and Danau Kerinci. It can be expected that local communities can actively protect and preserve the indigenous forests around Lempur Tengah, with local people being responsible for utilizing, managing and preserving the indigenous forests. The people, however, are not authorized to manage several of these indigenous forests which lie in the conservation area. This condition brings about conflicts between the local people and KSNP. The local government is trying to tackle these issues through the proposal of using several areas within the conservation area as customary forest rights/Hak Hutan Adat. Table 25 describes the proposed forest areas for the customary forest rights proposal.

Table 25 Proposed customary forest land in Kerinci Regency

\begin{tabular}{|c|l|c|l|}
\hline No & \multicolumn{1}{|c|}{ Name } & Area (Ha) & \multicolumn{1}{|c|}{ Location } \\
\hline 1 & $\begin{array}{l}\text { Tigo Luhah Permenti } \\
\text { yang Berenam }\end{array}$ & 252 & $\begin{array}{l}\text { Pungut Mudik Village, Air Hangat Timur } \\
\text { sub-district }\end{array}$ \\
\hline 2 & Tigo Luhah Kemantan & 426 & $\begin{array}{l}\text { Air Hangat Timur and Kemantan sub- } \\
\text { district }\end{array}$ \\
\hline 3 & Pungut Hilir & - & $\begin{array}{l}\text { Pungut Hilir Village and Air Hangat } \\
\text { Timur sub-district }\end{array}$ \\
\hline
\end{tabular}




\begin{tabular}{|c|l|c|l|}
4 & Bukit Gedang & - & $\begin{array}{l}\text { Pendung Hilir Village and Air Hangat } \\
\text { sub-district }\end{array}$ \\
\hline 5 & Bukit Sigi & - & $\begin{array}{l}\text { Tanjung Genting and Gunung Kerinci } \\
\text { sub-district }\end{array}$ \\
\hline
\end{tabular}

Source: Office of Forestry and Plantation of Kerinci Regency, 2013

\subsubsection{Creating indigenous forests to minimize conflicts and to protect the areas}

The local government has established several processes and procedures which can be used to determine if an area can be defined as an indigenous forest. Initially, the local government makes a proposal to the indigenous institutions. Afterwards, the Office of Forestry and Plantation conducts a field survey to analyze the real conditions in the area. Then, the officer writes the survey report completed with measuring and mapping the area, which is followed by establishing temporary boundaries and setting up a meeting. The meeting then determines the definite boundaries for the indigenous forests, as well as legal defining the boundaries. The final step is to propose the official report and obtain a regent decree. The establishment of an indigenous forest is expected to minimize conflicts related to forest utilization and illegal logging by the local communities in the conservation area.

"We are trying to meet the KSNP authority to propose several areas of the national park which should actually be designated as an indigenous rights forest, in order to reduce conflict and to support natural conservation in Kerinci Regency" (Respondent 60, Staff member of the Office of Forestry and Plantation, Kerinci Regency).

Limited area for community and state forests in Kerinci Regency has led to increasing difficulty in the land ownership process because most people do not want to sell their land to others. As a result, the communities ask the local government to find solutions so that they do not have to give up their land. To find out the solution, the local government considers that indigenous forest can provide an area for economic activities of local people. The communities are responsible for preserving natural resources based on their own regulations. Traditional rules prevent the area from adverse activities that may damage the forest. The people receive the customary sanctions and customary rights. State laws are put in place to protect the area from land abandonment, illegal logging and forest fires.

The local government determines sanctions for every case. The government also enforces local regulations and national laws to punish people who destroy natural 
environments within the state and community forests. In 2011, there were several instances of illegal logging and forest burning in the region. Table 26 shows data related to forest fires in Kerinci Regency in 2011.

Table 26 Forest fires in 2011

\begin{tabular}{|c|c|c|c|c|}
\hline \multirow{2}{*}{ Date } & \multicolumn{2}{|c|}{ Location } & \multirow{2}{*}{ Area of forest fire (Ha) } & \multirow{2}{*}{ Coordinates } \\
\hline & Village & District & & \\
\hline $\begin{array}{l}\text { Saturday, } \\
\text { June } 4^{\text {th }} 2011\end{array}$ & $\begin{array}{l}\text { Dusun } \\
\text { Tinggi }\end{array}$ & Siulak & $\begin{array}{l}\text { Forest fire occurred in } \\
\text { community area } \pm 50 \mathrm{Ha}\end{array}$ & $\begin{array}{l}\mathrm{S} 01^{0} 59^{\prime} 59^{\prime \prime} \\
\text { E } 101^{0} 19^{\prime} 30^{\prime \prime}\end{array}$ \\
\hline $\begin{array}{l}\text { Wednesday, } \\
\text { June } 8^{\text {th }} 2011\end{array}$ & $\begin{array}{c}\text { Sungai } \\
\text { Langkap }\end{array}$ & Siulak & $\begin{array}{l}\text { Forest fire occurred in } \\
\text { community area } \pm 20 \mathrm{Ha}\end{array}$ & $\begin{array}{l}\mathrm{S} 01^{0} 57^{\prime} 00^{\prime \prime} \\
\text { E } 101^{0} 22^{\prime} 55^{\prime \prime}\end{array}$ \\
\hline $\begin{array}{l}\text { Saturday, } \\
\text { June } 18^{\text {th }} \\
2011\end{array}$ & $\begin{array}{c}\text { Tanjung } \\
\text { Pauh } \\
\text { Hilir }\end{array}$ & $\begin{array}{l}\text { Keliling } \\
\text { Danau }\end{array}$ & $\begin{array}{l}\text { Forest fire occurred in } \\
\text { community area } \pm 10 \mathrm{Ha}\end{array}$ & $\begin{array}{l}\text { S } 02^{0} 07^{\prime} 50^{\prime \prime} \\
\text { E } 101^{0} 24^{\prime} 45^{\prime \prime}\end{array}$ \\
\hline $\begin{array}{l}\text { Monday, } \\
\text { June } 27^{\text {th }} \\
2011\end{array}$ & $\begin{array}{l}\text { Pendung } \\
\text { Hilir }\end{array}$ & Air Hangat & $\begin{array}{l}\text { Forest fire occurred in } \\
\text { community area } \pm 25 \mathrm{Ha}\end{array}$ & $\begin{array}{l}\mathrm{E} \quad 101^{0} \quad 24^{\prime} \quad 35^{\prime \prime S} \\
01^{0} 58^{\prime} 53^{\prime \prime}\end{array}$ \\
\hline $\begin{array}{l}\text { Sunday, July } \\
\text { 24th } 2011\end{array}$ & $\begin{array}{c}\text { Lempur } \\
\text { Danau }\end{array}$ & $\begin{array}{l}\text { Keliling } \\
\text { Danau }\end{array}$ & $\begin{array}{l}\text { Forest fire occurred in } \\
\text { community area } \pm 10 \mathrm{Ha}\end{array}$ & $\begin{array}{l}\text { S } 02^{0} 09^{\prime} 52^{\prime \prime} \\
\text { E } 101^{0} 25^{\prime} 40^{\prime \prime}\end{array}$ \\
\hline $\begin{array}{l}\text { Monday, July } \\
25^{\text {th }} 2011\end{array}$ & $\begin{array}{c}\text { Desa } \\
\text { Ambai } \\
\text { Atas } \\
\text { Desa } \\
\text { Hiang }\end{array}$ & $\begin{array}{l}\text { Sitinjau } \\
\text { Laut }\end{array}$ & $\begin{array}{l}\text { Forest fire occurred in } \\
\text { community area } \pm 25 \mathrm{Ha}\end{array}$ & $\begin{array}{l}\mathrm{S} 02^{0} 63^{\prime} 58^{\prime \prime} \\
\text { E } 101^{0} 30^{\prime} 24^{\prime \prime}\end{array}$ \\
\hline $\begin{array}{l}\text { Friday, } \\
\text { August } 12^{\text {th }} \\
2011\end{array}$ & $\begin{array}{c}\text { Tanjung } \\
\text { Pauh } \\
\text { Hilir }\end{array}$ & $\begin{array}{l}\text { Keliling } \\
\text { Danau }\end{array}$ & $\begin{array}{l}\text { Forest fire occurred in } \\
\text { community area } \pm 4 \mathrm{Ha}\end{array}$ & \\
\hline
\end{tabular}

Source: Government of Kerinci Regency, 2012

The majority of forest fires in Kerinci Regency occurs mostly between June and August and is commonly influenced by weather elements and farmers clearing forests for cultivation. Some respondents of the local government indicated that many of these fires may be the result of intentional activities. Moreover, the majority of burned land is owned by community residents. Government staff had a difficult time following up on the fires 
because farmers argued that they did not have any information about the land burning, resulting in officials only being able to record incidences and attempt to extinguish the fires.

''Burned land is usually owned by farmers and is included in the conservation area. We usually go to the area to record the event and then we asked farmers about the fires without giving legal retributions in order to avoid conflicts with them" (Respondent 61, Staff member of the Office of Forestry and Plantation Kerinci Regency).

Table 27 Results of security forest operations in Kerinci Regency in 2011

\begin{tabular}{|c|c|c|c|c|c|}
\hline \multirow{2}{*}{ No. } & \multirow{2}{*}{ Date } & \multirow{2}{*}{ Operation result } & \multicolumn{3}{|c|}{ Total } \\
\hline & & & pieces & $\mathbf{m}^{3}$ & unit \\
\hline 1 & April 28th, 2011 & Medang wood & 25 & 0,926 & \\
\hline 2 & May 11th, 2011 & Bernio wood & 253 & 8,42 & \\
\hline \multirow{3}{*}{3} & \multirow{3}{*}{ May 18th - 20th, 2011} & Medang wood & 28 & 0,76 & \\
\hline & & Balan Batu & 32 & 0,069 & \\
\hline & & Chainsaws & & & 2 \\
\hline \multirow{2}{*}{4} & \multirow{2}{*}{$\begin{array}{l}\text { May 23rd to 24th, } \\
2011\end{array}$} & Kayu Medang wood & 39 & 0,6 & \\
\hline & & Chainsaws & & & 1 \\
\hline 5 & July 15th, 2011 & Chainsaws & & & 1 \\
\hline \multirow{2}{*}{6} & \multirow{2}{*}{$\begin{array}{c}\text { August } 26 \text { s/d 28, } \\
2011\end{array}$} & Medang wood & 155 & 3,696 & \\
\hline & & Chainsaws & & & 1 \\
\hline 7 & December 5th, 2011 & Medang wood & 93 & 2,07 & \\
\hline & Total & & 625 & 16,541 & 5 \\
\hline
\end{tabular}

Source: Spatial Planning of Local Government Office of Forestry and Plantation of Kerinci Regency, 2012

Other problems arising in the four villages are illegal logging and encroachment of forest land. The local government has difficult time reacting to illegal situations because the majority of these cases occur in the conservation area which belongs to KSNP; local governments are only able to arrest offenders in state and indigenous forests. Typically, members of the communities catch the illegal loggers and bring them to local government 
officials who then cooperate with the KSNP staff, who has the authority to punish offenders, and then proceed with legal action.

\subsubsection{Improving communities' livelihoods from the perspectives of the local government}

Most of the livelihood sources in Kerinci Regency come from agricultural cultivation and plantations. The livelihoods of local people rely heavily on cinnamon, coffee and tea cultivation as their primary income source. The local government initiates activities to empower, control and monitor cultivation because these plantations are frequently managed by the Stated-Owned Plantation/Perseroan Terbatas Perkebunan Nusantara VI (PTPN VI).

Cinnamon is a perennial crop which is well-known as being produced in Kerinci Regency since ancient times. The total plantation area of Kerinci Regency is 40,944 ha, more than half $(23,997 \mathrm{ha})$ of which is used for the production of cinnamon cultivation. In 2011, approximately 53,546 tons of cinnamon was produced in the region, accounting for $2,231 \mathrm{~kg} / \mathrm{ha}$. Cinnamon is utilized as a raw material for food, pharmaceuticals and cosmetics. In 2011, 12,830 households in the regency grew cinnamon (Office of Forestry and Plantation, 2011). Cinnamon can also be utilized for food and home industries; moreover, cinnamon production is a significant driver in the local economy in many of the regency's villages, for example in the Sanggaran Agung Village. Furthermore, many households are able to use cinnamon for personal consumption in products such as cinnamon tea, cinnamon syrups and cinnamon chips.

The other main commodity grown in Kerinci Regency is coffee, which is produced on an area of 6,685 ha where productive coffee area is 4,531 ha. For example, a total area of 3,886 ha could produce $858 \mathrm{~kg} / \mathrm{ha}$ in 2011 . Within the regency, 7,665 households were identified as coffee farmers. Since 2005, there has been an NGO farmers named Lembaga Tumbuh Alami (NGO LTA) that has provided assistance to coffee. The NGO has presented many programs to farmer supported by local government. The association was established in 2005 to give training related to good agricultural practices for coffee cultivation, distribute coffee seed and help sell the farmer's coffee. The association also provided soft loans to allow the farmers to improve their productivity. This institution is very beneficial to both the framers and the local government. Empowerment pattern is expected by farmers for other commodities.

Tea plantations in the region are concentrated in the northern part of Kerinci Regency in villages such as Kayu Aro and those surrounding Mount Kerinci and many local people 
work as tea pickers; these plantations are managed by PTPN VI. Tea plantations are made up of 2,625 ha, with a productivity $2,200 \mathrm{~kg} / \mathrm{ha}$. Furthermore, there are 56 households in the region that are working in tea plantations.

\subsubsection{Water resources as another potential natural resource}

Water resources are another great source in the region managed by the local government. Kerinci Regency is surrounded by many lakes: Lake Kerinci, Lake Gunung Tujuh, Lake Lingkat and Lake Belibis, as well as other small lakes. These lakes are used for daily activities in local communities such as for irrigation, drinking water and micro-hydro energy. The lakes serve as the springs and water sources for other rivers, particularly Batang Merangin, Sikai, Rumpun, Tanduk, Dapdap and Semurup, among others. The largest river is Merangin, which flows all the way to the eastern part of Jambi. The lakes and the rivers are the sources for the Talon Barisal and Sungai Bukit Tappan waterfalls which further help with creating macro- and micro-hydro energy. Unfortunately, some of the watersheds are silted because of forest damage; damaged forests encourage the flow of soil masses into rivers.

In consideration of this problem, the local government has suggested several actions which support the utilization and conservation of water resources in the region. These support programs are outlined in the Mid-term Development Plan for 2009 to 2014 and cover issues related to the rehabilitation of critical and protected areas in the regions, rivers, and lakes, increasing community participation in the management of rivers, lakes and other water sources, and improving soil conservation. The local government has also developed more intensive programs which are focused on irrigation potential, with activities including the building of infrastructures such as irrigation systems and swamps, as well as encouraging the irrigation of groundwater, irrigation networks, preparation of irrigation land, rehabilitation of irrigation networks, and maintenance of irrigation systems.

There are several great challenges related to natural resource preservation in Kerinci Regency, particularly in KSNP, with particular focus on water resources and the cultivation of perennial crops. Local people expect the local government to act as a facilitator in the management of these resources. Furthermore, the communities are reliant on programs developed by the local government, as well as the government's laws, in order to obtain management responsibilities for the local natural resources. For example, communities in the village of Lempur Tengah expect legal recognition from the local government in order to create indigenous or customary forests in the KSNP area, in accordance with the indigenous 
forest rights. People in Kayu Aro and Gunung Tujuh also expect the local government to initiate meetings and collaborations with other partners, especially the KSNP management in order to obtain agricultural inputs for their plantations and to reduce instances of illegal logging. They also want the government to ensure their land and property rights.

"'For a long time, the farmers in the Kayu Aro sub-regency have had difficulty in obtaining land certificates and rights" (Respondent 35, 75 years old, coffee farmer in Kayu Aro).

\subsubsection{Limited resources on local government}

The local government has some weaknesses with regards to management of the area, particularly related to limited funds, authority and personnel. Moreover, the local government does not have full control to manage KSNP as they see fit. The human resource department of the local government plays an essential role in improving the community participation to aid in the preservation of natural resources and proper utilization of resources. In 2012, the staff of the office of Forestry and Plantation was made up of 105 workers, more than $50 \%$ of which outsourced from roles such as forest police and rangers. Forest police are essential in maintaining and monitoring the forest, particularly to prevent illegal logging and forest encroachments.

Implementation of assistance programs will greatly support the community and help to improve the local economy and the welfare of the population. However, there are some problems that may be an obstacle in the route to success for these programs. These problems include: (a) damaged watershed caused by illegal logging and extensive land conversion, (b) limited utilization of non-timber forest products and environmental factors, such as water resources, biodiversity, fresh air, a balanced climate, scenery and other essential aspects, (c) lack of community awareness regarding the maintenance of the environment. Unfortunately, many people in these local communities think that natural resources will be available forever in an unlimited amount, free of charge because water, air, climate and other natural resources are considered to be gifts from God that will never run out.

The legal basis for the government of Kerinci Regency with regards to the management of natural resources related to the forest utilization and protection policies, including those within national parks, have been established in Act No.32 of 2004 and Government Regulation No.28 of 2011 as part of the Region of Natural Resources and Conservation Areas. Article 2 paragraph 3 of Law 32 of 2004 states that "'The local 
government may act autonomously in order to improve people's welfare, public services and regional competitiveness". The management of natural resources under the local government authority of the district is defined in Article14, paragraphs 1-3. Each paragraph of the article can be summarized as follows:

(a) Paragraph (1): Obligations of the local government authority to sub-regencies include: a. planning and development control; b. planning, utilization and control over the spatial plan; c. organizing public order and public tranquility; d. provision of facilities and public infrastructures; e. handling the health sector; f. providing education; g. overcoming social problems; h. providing labor services; i. facilitating the development of cooperatives, small- and medium-sized enterprises; j. environmental control; k. land services; 1 . service the population and civil registration; m. general administrative services; n. capital investment services; o. implementation of other basic services; and other obligatory functions mandated by legislation.

(b) Paragraph (2), Activities of the sub-regencies are related to the existing government affairs focused on improving the communities' welfare in accordance with the conditions, uniqueness and core competence of the region.

(c) Paragraph (3), Implementations of Article 1, Article 10, Article12, Article13 and Article 14 paragraphs (1) and (2) are organized according to government regulations.

According to the law on regional autonomy, Kerinci Regency possesses the core natural resource, i.e., KSNP, which can be used to improve the local competitiveness of the region. Unfortunately, according to the government regulation on the management of natural reserve and natural conservation areas, the local government is only given the authority to manage natural conservation areas such as park designated forests. Such forests can be utilized for the collection of plants and/or animals in terms of origin, non-origin and not invasive methods for research, science, education, cultivation, culture, tourism and recreation (Government Regulation No. 28, 2011). Management arrangements and the implementation of natural reserve and natural conservation areas are outlined in Article 12, paragraphs 1, 2 and 4 of Government Regulation No.28 in 2011 as follows:

(a) Paragraph (1): Implementation of the natural conservation area (Kawasan Suaka Alam/KSA) and the natural preservation area (Kawasan Pelestarian Alam/KPA) are conducted by the local government, this, however, excludes areas within the forest park. (b) Paragraph (2): the government of the province and regency manage a forest park. 
(c) Paragraph (4): Implementations of the forest park by the government of the province and regency are referred to paragraph (2) and must implement the management unit established by the governor or regent.

\subsection{Perspectives of central government for managing the protected area according to the zoning system}

\subsubsection{Fundamental law and organizational structure of KSNP}

Referring to the Forestry Ministerial Decree Number P.03 / Menhut-II / 2007, which represents a change in the Decree of the Minister of Forestry Number P.29 / Menhut-II / 2006 and changes to the Decree of the Minister of Forestry of the Republic of Indonesia Number / Decision-II / 2002 dated June 10, 2002 states that the central objective of the national park is to provide a technical implementation unit to preserve the natural resources and ecosystems; the Director General of Forest Protection and Nature Conservation, as part of the Ministry of Forestry and Environment under the Republic of Indonesia is responsible for this implementation. Therefore, each agency of the national park, including the Kerinci Seblat National Park authority, is a branch of the national government, specifically the Ministry of Forestry and Environment, located in a local region.

The regulation also describes the Organization and Technical Implementation Unit of a national park, of which there are two classes: Class I and Class II. Class 1 is the office center of the national park, while Class 2 is the agency of the National Park. Based on the regulation, KSNP is classified as Class 1 with an organizational structure of Type A with organizational structure is defined as follows:

(a) Division of Administration

(b) Division of Technical National Park Conservation

(c) Division of National Park Management Area I

(d) Division of National Park Management Area II

(e) Division of National Park Management Area III

(f) Functional Group

The regulation changes also explain the empowerment and participation requirements that are needed for communities to increase their livelihood through capacity building and access utilization. Empowerment programs include the development of conservation villages, licensing of natural tourism, licensing of non-timber forest products, licensing for traditional use, as well as facilitating the partnership between forest holders and 
the community. To increase the participation of the local people, KSNP has given authorization for communities to know the national park's management plan. The community is also permitted to provide information, advice and considerations to KSNP that may help to maintain the region.

Implementation of these regulations is not as easy as in theory. In practical implementation, the KSNP authority controls accessibility to the conservation area and Gunung Tujuh mountain range, and is not really successful in involving the local communities. Access to the area is commonly controlled by the KSNP authority by ticketing natural lovers who are caught hiking and camping in the area. In some instances, conflict between KSNP and local communities occurs. The local youth generations in the village of Lempur Tengah initiated a natural lovers group, with one of their activities being to guide tourists through the conservation areas, such as Lake Kaco. The problem arising was determination of the ticket price by local people. The KSNP authority assessed that the price was too high for visitors. Moreover, profit from the ticket was not used as a source for maintaining the conservation area, creating further conflict. In other cases, consequently, it is often difficult for the staff to attract climbers due to previous problems, such as climbers being lost or accidents. Furthermore, climbers are rarely able to reach staff members in the event of emergency due to the office being understaffed.

The Indonesian government has issued a series of policies that affirm the role of the state in serving protected areas, especially national parks. In 1990, the Indonesian government issued Constitution No. 5 which is related to the conservation of natural resources and their ecosystems. This constitution defines the expectation for the conservation of biological resources, particularly those related to managing the utilization of natural resources wisely and ensuring supply continuity while maintaining and improving quality and diversity. The management of natural resources is the rights and obligations of the local government and communities. The Presidential Decree No. 32 of 1990 was released with focus being on the management of protected areas, which further outlines the roles of government at the regency, province and national level with regards to controlling the utilization of protected areas through monitoring and demolition. Government management of the protected areas, including natural conservation and wildlife areas, has been further reinforced by Government Regulation No. 68 of 1998 related to the natural reserve area and natural conservation areas. The regulation was then revised by the Government Regulation No. 28 of 2011 related to the management of these areas, in an effort to clarify the position and role of the local government in protected areas through 
focusing on community needs related to changes both at the national level and on an international scale. These regulations, No. 68 of 1998 and No. 28 of 2011, describe the process of designating an area as a national park; a national park is designated if an area meets the following criteria:

(a) The defined area has sufficient size to ensure the continuity of natural ecological processes

(b) It has unique natural resources including plants, animals, ecosystems and natural phenomena

(c) It has one or more intact ecosystems

(d) It has natural regions that can be developed to encourage tourism

(e) It can be classified into a core zone, utilization zone, wilderness zone, or other zone considering the rehabilitation objectives of the region, dependence of local people on the area, as well as conservation of natural resources and their ecosystems.

\subsubsection{Management authority and utilization of the conservation area in KSNP}

Purwanti (2008) conducted studies on the regulations related to the management of conservation areas. The research shows that authority over the national park management efforts are more concentrated in the central government than in communities and other stakeholders. The decentralization era, however, has been implemented due to Government Regulation No. 33 of 2004 centered on the authority of the central government and provinces. Authority figures set to organize and control the natural resources are split; for example, the central government's Ministry of Forestry does not provide many opportunities for the local governments and communities to actively control and maintain the natural resources. For example, the KSNP authority issued tickets and letter of permit for visiting the conservation area including research activities in Mount Kerinci, Gunung Tujuh mountain range, and other mountains. This condition affected problems related to the government or local community. Management conflicts are not only related to tourism issues, but also to the utilization of natural resources such as springs and energy resources.

Management of natural resources stated in the Regulation necessarily contradictory with the mandate of Constitution No. 32 of 2004 about Local Government and Constitution No. 26 of 2007 about the Spatial Planning. Constitution No. 32 of 2004 is intended as a tool to regulate the power and authority sharing between the central and local governments. The province and regency authorities are responsible for spatial planning and spatial utilization as described in Articles 13 and 14. These authorities range from national, province and 
regency level figures which have been outlined in detail in Constitution No 26 of 2007. Local governments have the authority to establish a strategic area, determine spatial planning of strategic areas, utilize the strategic areas and control the strategic areas. However, the local government of Kerinci Regency is not able to optimally utilize the natural resources in KSNP. The KSNP authority has extensive control over the maintenance and management of KSNP. Therefore, the central government has not established collaboration among stakeholders in an effort to gain control over the management of KSNP.

Nevertheless, decentralization in Indonesia provides an opportunity for local communities, NGOs, as well as local, national and international enterprises, in addition to universities, research institutions and government to infuse their interests into a similar vision in a collaborative management effort. The Forestry Minister's Regulation No.19/Menhut-II/2004 put the Director General of Forest Protection and Natural Conservation in charge of developing and controlling the implementation of this collaboration (Article 10) in natural reserve and natural conservation areas. Management activities for integrating these two regions are as follows:

(a) Arranging the area to support the zoning system and area border

(b) Creating a management plan for the natural conservation area (Kawasan Suaka Alam/KSA) and the natural preservation area (Kawasan Pelestarian Alam/KPA)

(c) Capacity building to support the zone as inventory or monitoring of flora, fauna and the ecosystem, fostering and monitoring the population and habitat types, as well as rehabilitation of areas outside the natural conservation and national park core zone.

(d) Utilizing the area in a way to promote natural tourist destinations and environmental services. This includes the development of studies related to potential and natural attractions and environmental services, as well as planning activities for nature tourism, education and interpretation of program, media development and infrastructure improvement.

(e) Research and development related to flora, fauna and their ecosystem, as well as the identification of social and cultural characteristics of local people.

(f) Protection and safety potential for regions to strengthen protection and security within the area, as well as to reduce and control forest fires.

(g) Human resource development to support the management of KSA and KPA, specifically pertaining to the education and training of employees and local community members. 
(h) Building infrastructure to support collaboration.

(i) Encouraging community participation; for example, through programs intended to improve people's welfare and their awareness of maintaining natural resources.

The management authority of KSNP refers to the government regulations and constitutions that are applicable to the park and are supervised by the KNSP authority (Balai Besar Taman Nasional Kerinci Seblat). There are central and branch offices that focus on the preservation the conservation areas according to the Regulation of Ministry of Forestry No.P.03/Menhut-II/2007. Table 28 shows the various offices/divisions which have authority in KSNP.

Table 28 The offices of the KSNP authority and its divisions

\begin{tabular}{|l|l|c|}
\hline \multicolumn{1}{|c|}{ Division } & \multicolumn{1}{|c|}{ Address } & Regency/ Province \\
\hline $\begin{array}{l}\text { Office of the KSNP } \\
\text { authority }\end{array}$ & Jl. Basuki Rahmat No. 11 Sungai Penuh & Kerinci \\
\hline $\begin{array}{l}\text { Division of National Park } \\
\text { Management in Region I } \\
\text { Jambi }\end{array}$ & Jl. Lintas Sumatra Km 4 No. 44 Bangko & Merangin \\
\hline $\begin{array}{l}\text { Division of National Park } \\
\text { Management in Region II } \\
\text { West Sumatera }\end{array}$ & $\begin{array}{l}\text { Jl. Khatib Sulaiman No. 46, Padang- } \\
\text { West Sumatera }\end{array}$ & West Sumatera \\
\hline
\end{tabular}

Source: The KSNP authority, 2014

\subsubsection{Zoning system for empowering local people from the perspectives of KSNP}

\subsubsection{Conflicts related to the utilization of the conservation area in KSNP}

The existence of indigenous people inside and in surrounding areas of the national park had frequently been a source of conflict before the area was designated as a conservation area (Blouch, 2010; Mulyana, et al., 2010; Wood, Sheil, Syaf, \& Warta, 2014). Conservation policies in Indonesia tend not to involve communities, as well as preventing community members from utilizing conservation areas. There are 534 conservation areas and 50 national parks, encompassing an area of approximately 28.2 million hectares (Mulyana, et al., 2010). Blouch (2010) showed that communities living in the villages surrounding KSNP are often involved in conflicts with the KSNP authority, particularly due to the establishment of boundaries in the conservation area without the involvement of local 
communities. For example, a 2,500 km boundary has been established and has represented a continual source of conflicts between park management officials and local communities. The KSNP staff determined that community activities could damage the conservation area, despite participation in these activities long before the boundary was defined. The human resource department of KSNP is understaffed and is not able to provide sufficient security measures to fully control these conflicts. In an effort to mitigate these conflicts, the World Bank gave a 130 million USD from 1996 to 2002, in the form of a Global Environment Facility (GEF) grant. Furthermore, the project was called Kerinci Seblat Integrated Conservation and Development Project (KS-ICDP) and covered 1.37 million hectares within KSNP; this represents nearly half of Indonesia's protected area (Wood, Sheil, Syaf, \& Warta, 2014). The objective of the project was to improve community awareness regarding the importance of maintaining the national park, as well as mitigating threats to the area. The grant provided 30,000 USD per village, intended for building/improving infrastructure and establishing agricultural areas outside the park, as well as revolving grant programs. Villages were eligible to receive grants if they followed the negotiated conservation agreements; these agreements demanded that funds were to be used for ensuring activities that were compatible with conservation. This program was also intended to stabilize land use outside of the protected area's boundaries, as well as to increase local income in order to reduce the exploitation of natural resources, especially in the protected area (Blouch, 2010).

The project initiated village conservation agreements which provided specific development assistance in return for community cooperation in efforts related to park protection (The World Bank, 2006; Wood, Sheil, Syaf, \& Warta, 2014). Local communities that signed an agreement with the park received a village conservation grant (30,000 USD) to support local initiatives. The grant was disbursed in two steps; first, the grant was delivered upon the agreement being signed. Second, the funding was given to the community after the commencement of agreed upon activities. One of the principal results of these agreements was a park zoning plan that could be used to seek equitable solutions for local populations. These zoning agreements also provide a mechanism for dealing with any future management issues that may arise (Blouch, 2010; Wood, Sheil, Syaf, \& Warta, 2014).

\subsubsection{Zoning system for managing KSNP}

The zoning system put in place by Kerinci Seblat National Park was officially established by the Decree of the Director General of Forest Protection and Natural Conservation No. 07/IV-KK/2007. The zoning system of KSNP consists of: 
1) The core zone which has a total area of $744,990.3$ ha, or $53.62 \%$ of the total area; moreover, this zone reaches the following areas: Bukit Barisan, Kerinci Regency, Bungo, Dharmasraya, Solok, Solok Selatan, Pesisir Selatan, Muko-Muko, Bengkulu Utara, Rejang Lebong, Lebong, Musi Rawas and Lubuk Linggau.

2) The wilderness zone covering an area of $463,394.7$ ha, or $33.35 \%$ of the total area; this zone includes the areas surrounding the core zone.

3) The utilization zone is comprised of $17,802.6$ ha, or $28 \%$ of the total area, and includes areas in Jambi, Bengkulu, West Sumatra, and South Sumatra provinces.

4) The rehabilitation zone with an area of $136,790.9$ ha, or $9.84 \%$ of the total area, and is spread out in four provinces, similar to the utilization zone.

5) The specific zone covering an area of $13,798.3 \mathrm{ha}$, or $0.99 \%$ of the total area

6) The traditional zone

Regarding the regulation and zoning map, the conservation area is mostly located within Kerinci Regency and Jambi province. Table 29 shows the locations/villages that are included in the utilization zone, especially those in Kerinci Regency.

Table 29 Location of tourist destinations in Jambi Province

\begin{tabular}{|c|l|l|}
\hline No & \multicolumn{1}{|c|}{ Name } & \multicolumn{1}{|c|}{ Location/sub-district } \\
\hline 1 & Mount Kerinci & Kayu Aro \\
\hline 2 & Lake Gunung Tujuh & Gunung Tujuh \\
\hline 3 & Hill Tapan & Sungai Penuh \\
\hline 4 & Waterfall Telun Berasap & Gunung Tujuh \\
\hline 5 & Mount Belerang & Gunung Raya \\
\hline 6 & Mount Mesurai & Jangkat and Lembah Masurai \\
\hline 7 & Waterfall Sungai Mentilin & Jangkat \\
\hline 8 & Waterfall Mendikit & Jangkat \\
\hline 9 & Lake Belibis & Kayu Aro \\
\hline 10 & Lake Duo & Gunung Raya \\
\hline 11 & Pancaro Rayo and Pincuran Gading & Keliling Danau \\
\hline 12 & Swamp Bento & Gunung Tujuh \\
\hline 13 & Cave Kasah & Gunung Tujuh \\
\hline 14 & Waterfall Pauh Tinggi & Gunung Tujuh \\
\hline 15 & Swamp Ledeh Panjang & Kayu Aro \\
\hline 16 & View Alam Bukit & Sungai Penuh \\
\hline & & \\
\hline
\end{tabular}




\begin{tabular}{|c|l|l|}
\hline 17 & Lake Pauh & Jangkat \\
\hline 18 & Lake Depati Empat & Jangkat \\
\hline 19 & Grao Gedang and Grao Matahari & Jangkat \\
\hline 20 & Grao Solar, Grao Nguak, and Grao Kunyit & Jangkat \\
\hline 21 & Hill Sitinjau Laut & Sungai Penuh \\
\hline 22 & Hill Kayu Embun & Jangkat \\
\hline
\end{tabular}

Source: The KSNP authority, 2014

\subsection{Empowerment for environmental preservation}

\subsubsection{Perspectives of forest policies in the era of decentralization}

Decentralization in Indonesia was implemented after the 1998 reformation. The local government has been granted the authority to manage the region and improve the local economy, largely as a result of decentralization. This authority is given as part of the Constitution of 1999, along with the implementation of 2000 and the revision of 2004 . Decentralization also creates opportunities for the local government to manage the region's natural resources and improve the governance of environmental preservation at the regional level. These changes may, however, have resulted in some problems related to environmental issues (Manor, 1999; Colfer \& Capistrano, 2005; World Bank, 2006).

Several Asian nations have had problems related to environmental management failures, namely India, Bhutan, Vietnam, Thailand and Indonesia. Many of the centralized regulations influenced failures in terms of forest management, including issues in protected forests (Selfa and Endter-Wada, 2008). Centralized management may have played a role in traditional forest users being labeled as illegal loggers. Local users who extracted timber, for example, were viewed as a threat to the forest and to the conservation of biodiversity.

Decentralization was established in an effort to better manage natural resources, including conservation areas which are viewed as national resources. The central government manages natural resources with the objective of achieving sustainability. The designation of a national park is often done to aid in the management of conservation regions (Purwanto, 2005). Management of conservation areas as organized by the central government has resulted in local regulations, and indigenous people rights, to lose validity (Krott, et al., 2014).

Therefore, the majority of local governments throughout Indonesia, including the local government of Kerinci Regency, do not view national parks as a priority issue in local 
politics. Local governments tend to be relatively passive with respect to management of conservation areas because those that are part of a national park are managed by the central government; furthermore, many local governments lack the necessary capital and human resources to manage the conservation area (Colfer \& Capistrano, 2005; Secco, Re, Pettenella, \& Gatto, 2014).

\subsubsection{Challenges for the management of Kerinci Seblat National Park}

The main challenge of forest management is the dependence of local people on agricultural and forestry products. One solution to this problem is the creation of a preserved area, such as the establishment of a national park in the tropical forests in Indonesia (Mehring et al., 2011). The development of an institution is required to ensure the implementation of a safe and ecological system for long term utilization in the protected areas (Mehring et al., 2011). An institution is defined as a set of work regulations that are used to determine which parties have suitable requirements for collaborating in decision making with respect to the specific area (Ostrom, 1990).

From the economic and political perspectives, conservation is often viewed as a threat to development. Local communities live in and within surrounding the areas that are part of national park and often rely on the natural resources in the park for their economic wellbeing (Mulyana et al., 2010). Proper maintenance of KSNP needs to take into consideration three main aspects of sustainable management: economy, society and environment. A national park is a conservation forest which has two functions: First, it is an area that is dedicated to the preservation and conservation of the ecosystem and biodiversity. Second, it is a source of livelihood for local populations, particularly those participating in controlled utilization (Hidayat, Haba, \& Siburian, 2011). Management of KSNP with the intention of achieving sustainability is conducted through the implementation of a zoning system so that KSNP can be utilized for improving research, education, culture, tourism and recreation, as stated in Constitution No. 5 of 1990.

To improve the performance of a national park management program, four main elements are required (MacKinnon et al., 1986; Mappatoba, 2004): (1) Human resources within the national park should pay attention to environmental management efforts, including habitat and population management, administration and maintenance, information and research, and tourism management on various levels; (2) setting clear boundaries and implementing a zoning system is necessary to achieve effective actions and sustainability, 
(3) the development of realistic planning; (4) increasing and improving management facilities; and (5) education and research development. 


\section{Chapter VII. Ecotourism as a Driver for Developing the Economy and Conservation Activity}

\subsection{Contribution of the tourism sector in Indonesia}

Tourism has become increasingly important for developing countries, especially for Indonesia. Tourism serves as the fifth largest sector in the nation's GDP (Gross Domestic Product), after oil and gas, coal, palm oil and rubber. The tourism sector contributed US\$ 11,166.13 billion to the GDP in 2014. The number of foreign tourists has increased by approximately $16.66 \%$ from 2009 to 2014, ultimately reaching 888,3 thousand foreign tourist in February 2016. Furthermore, the average number of domestic tourists increased by about $8.66 \%$ in that time period (Central Statistical Agency of Indonesia's Government, 2016; Indonesia's Ministry of Tourist, 2016)

Indonesia is known as being one of the greatest biodiversity hotspots in the world, with approximately 49 different types of ecosystems. Even though the area of Indonesia represents only $1.32 \%$ of the total world area, it houses $10 \%$ of the plant species in the world, $12 \%$ of mammal species, $16 \%$ of reptile and amphibian species, $17 \%$ of bird species, $25 \%$ of fish species and $15 \%$ of insect species. Indonesia boasts approximately 120 potential ecotourism areas including national parks, forest parks, ecotourism parks and marine tourism parks (Manurung, 2002). The Indonesian government has established programs that are focused on the promotion of the tourism sector, particularly ecotourism. The rich biodiversity of the nation is a factor which can be taken advantage of to get local, regional and even international tourists visiting national parks. Tourism has developed as the world's largest industry and important sector for Indonesia. International tourists have increased by over $35 \%$ from 1974 to 2011 . The overall number of tourists is predicted by National Ministry of Tourist to grow by an average of $4.1 \%$ annually for the next five years (until 2019), reaching 240 trillion and specially in 2016 reaching 172 trillion (Widianto, 2016). Tourism is the largest sector for employment worldwide, both directly and indirectly, with nearly 200 million jobs, or some 10\% of the available jobs globally (Leslie, 2015). Tourism has become increasingly important for developing countries, especially for Indonesia. The average number of domestic tourists within Indonesia increased by $1.60 \%$, while foreign tourists increased by $5.10 \%$ between 2004 and 2010 (Indonesia's Ministry of Tourist, 2016).

The potential tourism that can be greatly developed for Indonesia is ecotourism which is sometimes referred to as "'green tourism', "'soft tourism", "responsible tourism', 
or 'sustainable tourism". Ecotourism is different from other forms of tourism because it refers to individualized rather than mass tourism and has similarly increased capacities to generate a range of environmental, economic, social and cultural impacts. Indonesia is known as a country with some of the greatest biodiversity in the world. Furthermore, there are approximately 49 different types of ecosystems within the country. Even though Indonesia's land area is only $1.32 \%$ of the total world area, it contains $10 \%$ of plant species in the world, $12 \%$ of mammal species, $16 \%$ of reptile and amphibian species, $17 \%$ of bird species, $25 \%$ of fish species and $15 \%$ of insect species. Indonesia has approximately 120 potential ecotourism areas including national parks, forest parks, ecotourism parks and marine tourism parks (Manurung, 2002).

\subsubsection{Ecotourism as a recent trend to link conservation and poverty alleviation in protected areas}

Moreover, many studies have revealed the possibility of using ecotourism for environmental conservation and poverty reduction. Sunderlin, et al. (2005) explain an overview of livelihoods, forests and conservation in developing countries. There are three factors which must be considered when developing strategic poverty alleviation in relation to ecotourism: 1) areas of chronic rural poverty and natural forests tend to overlap, 2) it is critical to distinguish between the use of forest resources to prevent rural societies from falling into deeper poverty, and 3) there are intrinsic qualities of forest resources and poverty alleviation.

Demand for ecotourism, especially in protected areas, such as national parks and wilderness reserves increases every year. This may be related to several factors: changing attitudes regarding nature, dissatisfaction with conventional tourism which frequently ignores social and ecological aspects and increasingly easy access to natural areas. WTO (1998) stated that ecotourism and all nature-related forms of tourism account for approximately $20 \%$ of total international travel worldwide. Recreational ventures in protected areas throughout Southeast Asia need stronger contextualization of alternatives, as well as better market awareness if the economic and preservation benefits of tourism are to be maximized (Cochrane, 2006).

In many countries, parks and protected areas have become primary destinations of tourism and recreation, as well as a key attraction for ecotourism. Ecotourism, also referred to as green tourism, soft tourism, responsible tourism, or sustainable tourism, is different from other forms of tourism because it refers to individualized tourism rather than mass 
tourism. Demand for ecotourism, especially in protected areas such as national parks or wilderness reserves increases every year. This may be the result of several factors: changing attitudes related to nature, dissatisfaction with conventional tourism which has mostly ignored social and ecological aspects, and increasingly easy access to natural areas. WTO (1998) stated that ecotourism and all nature-related forms of tourism account for approximately $20 \%$ of total international travel worldwide. Many studies have established that ecotourism has had a significant impact on poverty reduction in peripheral communities (Clifton and Benson, 2006; Walpole and Goodwin, 2000).

The Indonesian government currently claims that the total area of protected forests within the country is equivalent to two-thirds, or 16 million ha, of the total land area of Indonesia (The World Bank, 2006). A national park is a natural conservation area with an original ecosystem that is managed under a (buffer) zoning system and is intended to support science, education, plant propagation and animal breeding, tourism and recreational purposes. In 2010, there were 43 terrestrial national parks with a total land area of 12,328,523.34 ha and 7 marine national parks with a total land area of 4,043,541.30 ha in Indonesia (Ministry of Forestry Republic of Indonesia, 2012).

\subsubsection{Ecotourism offers a better method of poverty reduction in areas surrounding national parks}

Regarding the law of forestry, there are many advantages to maintaining protected areas, particularly related to economic and environmental benefits for high-value services. Currently, the forestry sector in Indonesia, including national parks, has not made optimal contributions to poverty reduction, social and economic development, and nature preservation. The benefits of the nation's national parks are now able to be explored due to the era of reform and decentralization, which has made these opportunities more realistic (Mappatoba, 2004.) The law of decentralization was originally implemented in 1999, before being revised in 2004, divided the roles and the responsibilities of forest management and revenue management between the central and local governments (Engel et al., 2013). The largest proportion of the income (about 80 percent) generated as a result of national parks is returned to the local governments, with most of the revenue being distributed to the district in which the park is located. Furthermore, in addition to financial affairs, forest governance has become a serious concern within the country (The World Bank, 2006).

Many studies have determined that ecotourism has had a significant impact on poverty reduction in peripheral communities and has served as a means to increase natural 
preservation. Clifton \& Benson (2006) attempted to identify the impact of nature and sociocultural aspects on Indonesian ecotourism. The results indicate that the positive nature of socio-cultural impacts perceived by local communities alongside the irregular nature of economic benefits to local communities.

Demand for ecotourism especially in protected areas such as national park or wilderness increases every year. It can be related to several factors: changing attitudes towards back to nature, dissatisfaction with conventional tourism which ignored social and ecological aspects, and access to natural areas is easy. WTO (1998) stated that ecotourism and all nature-related forms of tourism account for approximately $20 \%$ of the total international travel. Recreation provision in protected areas in South East Asia needs stronger contextualization as an alternative, and better market awareness if the economic and preservation benefits of tourism are to be maximized (Cochrane, 2006).

Many studies have established that ecotourism has a significant impact to the reduction of poverty in peripheral communities and as a mean to increase natural preservation. Clifton and Benson (2006) has identified the nature and causes of sociocultural impacts of ecotourism in Indonesia. The result shows that the positive nature of socio-cultural impacts perceived by local communities alongside the irregular nature of economic benefits to local communities. Walpole and Goodwin (2000) have identified that distributional inequalities encourage external operators and urban society rather than rural residents of dragon tourism in Indonesia.

\subsection{Lesson from the empirical study: The challenge of the decentralization era for the development of ecotourism in protected areas}

The decentralization concept, which was first introduced in Indonesia in 1999, has given a great opportunity to both, local governments and national agencies to present good governance in the management of national parks, in an effort to increase investments for local economies and provide other benefits for local people; the results, however, have not been as expected. In reality, the opposite situation occurred due to weak forest governance which resulted in a diminished investment climate, degraded rural economy, increased criminalization in the field of forestry, and looted of the forest and conflict initiation by antiregulation people.

Land disputes, illegal logging, forest encroachment, forest fires and the agrarian intensification process are further negative situations in protected forest areas which have resulted from decentralization. Furthermore, it has been proven many times that these 
problems have begun to spread to and affect the national parks. The illegal activities taking place in forest areas affect local communities, companies and local governments. The zones surrounding parks and forest reserves are frequently the sites of conservation conflicts.

Conflicts and criminal activities in forest areas have arisen due to economic inequality and poverty in the communities surrounding the area. Forest areas including protected areas are sources of primary livelihood for 10 million of the 36 million people who are categorized as poor in Indonesia (The World Bank, 2006). Poverty in Indonesia is based on the minimum standards of living, specifically a daily per capita expenditure below U.S. $\$ 1$.

\subsubsection{Perspectives of local people on the development of ecotourism potencies inside and in surrounding regions of the conservation area}

Studies pertaining to the social impacts of tourism have been extensively conducted, especially in developing countries. However, it is almost unknown how these changes are related to the relationship between the environment and human beings (Gossling, 2002). There are several social problems arising from tourism activities, such as culture changes, pressure of local people mindset and social dislocation. This study analyzes the perceptions of local people regarding socio-cultural, economic and ecological aspects. Furthermore, the research describes the understanding of the local people relating to the environment in terms of socio-cultural aspects, benefits and costs of ecotourism involved in Kerinci Seblat National Park. The respondents are represented by various stakeholders consisting of local community members, local government officials, national park personnel, NGO staff members, domestic and international visitors, and academicians.

An in-depth interview was conducted in the form of semi-structured interviews in the Indonesian language and was completed in two steps: First, the interviews were conducted from July to August 2013, with more interviews taking place from September to November 2014. Focus Group Discussions (FGDs) were conducted with the staff members of the KSNP office in November 2014. The interviews lasted anywhere from 30 minutes to 2.5 hours, with follow-up efforts taking place as needed. Furthermore, there were three steps for collecting the primary data that resulted from these interviews. This process involved taking notes and archiving them. The primary data were supplemented by the secondary data that was gathered from documents supplied by the local and provincial governments, national park, sub-districts, NGOs and published academic literature. 
The northern and the southern parts of Kerinci Regency were the primary focus locations. Consequently, there are some differences in the perspectives of local communities related to the existence and potential for tourism in each region. The northern part of Kerinci includes the villages of Gunung Tujuh and Kayu Aro; while the southern part includes the villages of Lempur Tengah and Sanggaran Agung. The next section will describe the perspectives of each region.

\subsubsection{History of Kerinci and the indigenous people of Kerinci}

In order to fully understand the situation in the research target area, namely Kerinci Seblat National Park and surrounding areas, it is important to understand the history of the region. Historically, Kerinci the name of the valley that lies in the middle of the national park that is now known as Kerinci Seblat National Park. There are two variations in the origin of the word "'Kerinci": First: the word 'Kerinci" originally comes from the ancient people of the area. Before the Christian, there is no explanation about people who live in Kerinci. There are differences both in writing and dialect of each village to say "Kerinci". Every village has a unique dialect and/or language (Agung, 2001).

The following are several examples of how Kerinci is said in various local dialects: Kincai, Kincei, Kinci, Krinci and Kurinci. The word 'Kerinci" for Netherland and English people who colonized Bengkulu was "Korintji'". The English-speaking people mention it as ' 'Korinchi',. With respect to the meaning of Kerinci, local people usually connect the term to the region cultural history. First, the word 'Kerinci' originally comes from the word "'Kunci", or the key, which means that the region is a closed area. Geographically, the Kerinci valley is located near the Bukit Barisan. Some people recognize Kerinci as a closed area. The other story mentioned that Kerinci word has two roots of words "Kering and Cair" or "Dry and Liquid". It means that Kerinci is a valley which has an island in the middle, Tanah Cuguk. The foothills are covered by swamps. The swamps are dry in dry season and adversely in the rainy season (Agung, 2001).

The ethnic composition in the Kerinci region is complete and unique (Agung, 2001; The KSNP authority, 2014; Government of Kerinci Regency, 2012). Referring to several studies focused on the history of Indonesia, specifically the arrival of the first inhabitants, it has been determined that the ancient people of Kerinci are of mixed origin, with people living in the valley being referred to as "Kecik Wok Gedang Wok" and those outside the valley as Melayu Tua (Proto Melayu). An ancient people group called 'Old Malay" is regarded as the original inhabitants of Indonesia, as well as many other Southeast Asian 
nations such as Malaysia, Vietnam, Thailand, the Philippines, and the ancestors of the peoples of the Polynesia islands covering Hawaiian islands.

Today, Kerinci consists of various ethnic groups, but is predominantly those descended from the following regions: Kerinci, Melayu Jambi, Minangkabau and Java. These cultures introduce various habit and cultural aspects into the daily life of local villages. Cultural diversity can be seen in many aspects of the communities' lives, for example the annual art performance, the Festival of Lake Kerinci. The strength of various cultures and customs help to support natural tourism and increase the attractiveness of the area with respect to ecotourism.

\subsubsection{Lempur Tengah Village: managing ecotourism based on customary rights and conflicts related to ecotourism attractions}

Chapter 5 of this dissertation explained that Lempur Tengah Village is the oldest village in Kerinci. Most of the forest that lies within the village are maintained and preserved by the local customary law. The majority of local people intend to maintain Lempur Tengah as a customary village where people refer to the values, norms and customary laws of the village for handling problems and maintaining order.

\footnotetext{
"The indigenous people of Kerinci are not capable of destroying the forests or natural resources. They understand that the forest is the customary forest which must be maintained according to the customary laws. Moreover, in each region there are Depati who set up policies related to the values and norms of customary law' (Respondent 24, Community leader, Sungai Penuh city).
}

Lempur Tengah Village, as well as adjacent villages, has many potential tourist destinations such as lakes, indigenous forests and well-preserved ancient culture. Lakes and waterfalls in Lempur Tengah are also popular destinations for both local people and people from outside the region; examples of such lakes and waterfalls include Lake Lingkat, Lake Kaco, Lake Kecik, Telun Tanjung Waterfall and the indigenous forest of Lekuk 50 Tumbi. The destinations in Lempur Tengah are divided into two types: Natural scenery and historical heritage. Most of the natural destinations are managed by the KSNP authority due to them being within the conservation area. The historical destinations are jointly managed by the local communities and local governments. 
The tourist destinations of cultural heritage are the remains of ancient buildings such as mosques, rice granaries, ancient stones like cylindrical stones, gong stones and batuah stones, and ancient houses, including cultivation systems which were used at the time.

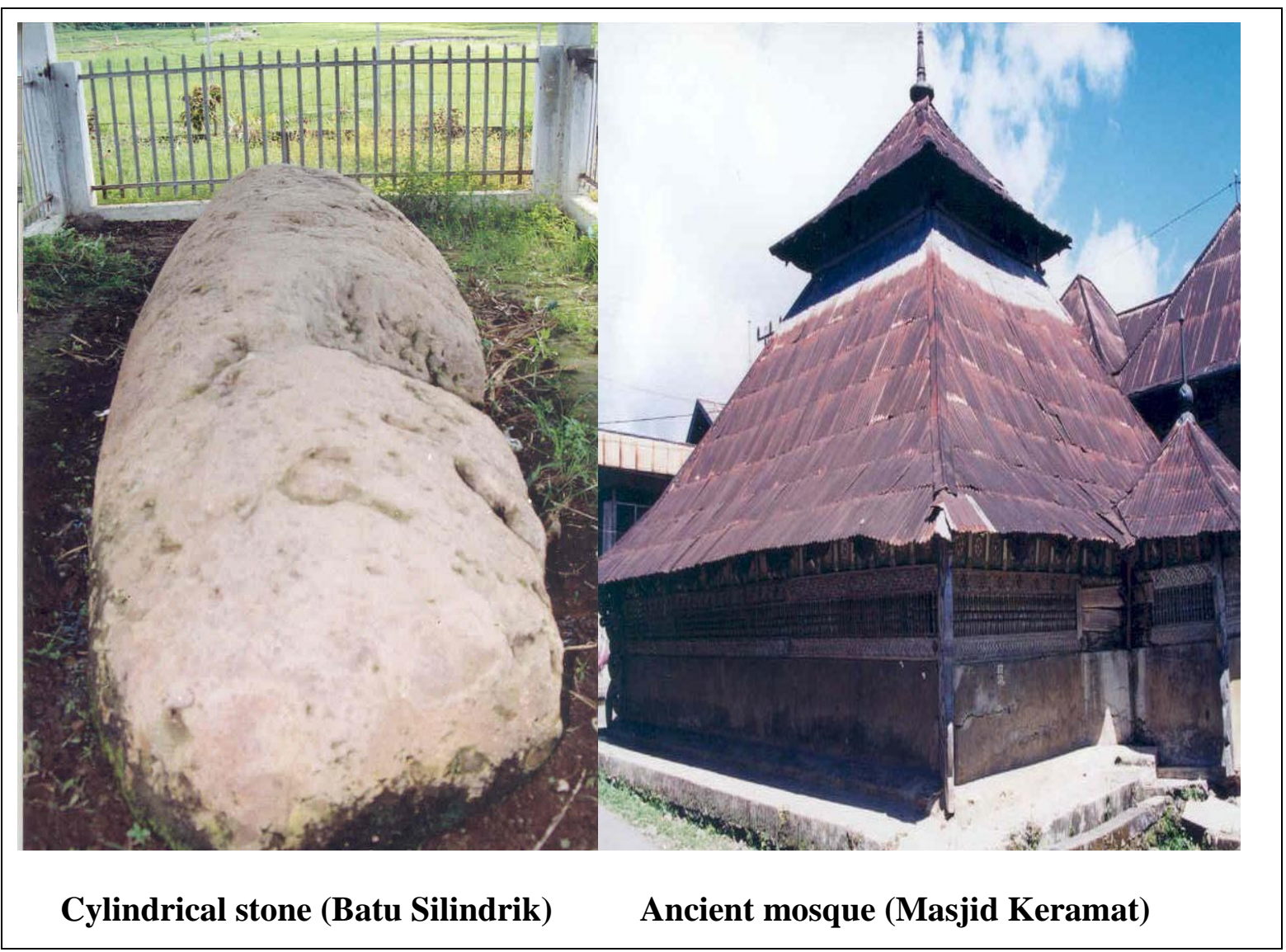

Source: The Tourism Office of Kerinci Regency,2014

\section{Picture 16 Archaeological heritage of indigenous people in Lempur Tengah}

Conflicts related to the management of ecotourism have arisen due to land previously managed by the local communities being designated as conservation areas and part of the KSNP core zone, for example Lake Kaco.

It is not easy for local people to manage the tourist attractions, especially with regards to promotion of the attractions. Moreover, the staffs of the KSNP authority are relatively reluctant to support conservation endeavors conducted by people from the villages. Nevertheless, local people always try to promote the tourist destinations in the region such as Lake Kaco. It takes an average of three hours to walk to Lake Kaco because the road is not good and is even dangerous in some instances due to the potential for tourists to meet wild animals such as tigers and bears, among others. However, these animals may serve as attractions for eco-tourists. 
Lake Kaco provides one example of the difficulties in managing the region's natural resources. It is generally difficult to find a win-win solution in which each actor benefits. This is especially true for members of local communities and the staff at the KSNP authority. It is different with local government that in indirectly supports local people in the management of tourist attractions in an effort to increase their incomes. The support of the local government is not only related to economic aspects, but also to social and cultural elements of the local people. Moreover, the local people maintain their values and norms which have been established over long periods of time; these are commonly represented in the daily lives of the people, as well as in their behavior towards the environment. A large proportion of the people living in Lempur Tengah are elderly people, while the majority of younger people prefer to find jobs in other cities or countries. Several associations have been established abroad, particularly in Brunei and Malaysia, by people from Kerinci Regency. These associations attempt to present people in other countries with information about the Kerinci culture, as well as promote the Kerinci Regency potential for ecotourism.

Conflicts, with regard to the management of ecotourism in the conservation area between the local community and The KSNP authority, have occurred as a result of ticketing. Youth in the community, as well as community leaders and local government officials established a youth association known as the Pancagura adventure group. The association seeks to provide opportunities for tourism and to guide tourists who want to visit the natural attractions in Lempur Tengah. In 2014, there were 25 members in the association, most of which were in senior high school. These members were trained to guide tourists and to serve as forest security to keep out illegal loggers. Visitors could enter the area by purchasing a ticket for IDR 150 thousand (\$10), with IDR 20 thousand (\$1.5) going towards administrative fees. In an effort to avoid conflicts with KSNP, the association refrained from building a facility to welcome visitors. One of the local respondents stated the ticket price has been assigned by stakeholders and it is known by local communities and local government which then forwarded to the manager of KSNP. This conflict related to the ticket price was continuing until this study took place.

\subsubsection{Sanggaran Agung village: strengthening the economy}

The Sanggaran Agung Village, in Danau Kerinci Sub-district, is located in the area around Lake Kerinci, which is a very popular attraction for tourists and serves as a symbol of tourism for Kerinci Regency. Here, there is a prestigious event conducted every year, The Lake Kerinci Festival (Festival Masyarakat Peduli Danau Kerinci). The festival 
presents various traditional forms of art and entertainment such as traditional dances, songs and handmade products. The festival has taken place 14 times in 2015 alone. During the festival, the local tourist office helps to promote some of the region's tourist attractions such as waterfalls and mountains. The festival takes place over a period of three to four days.

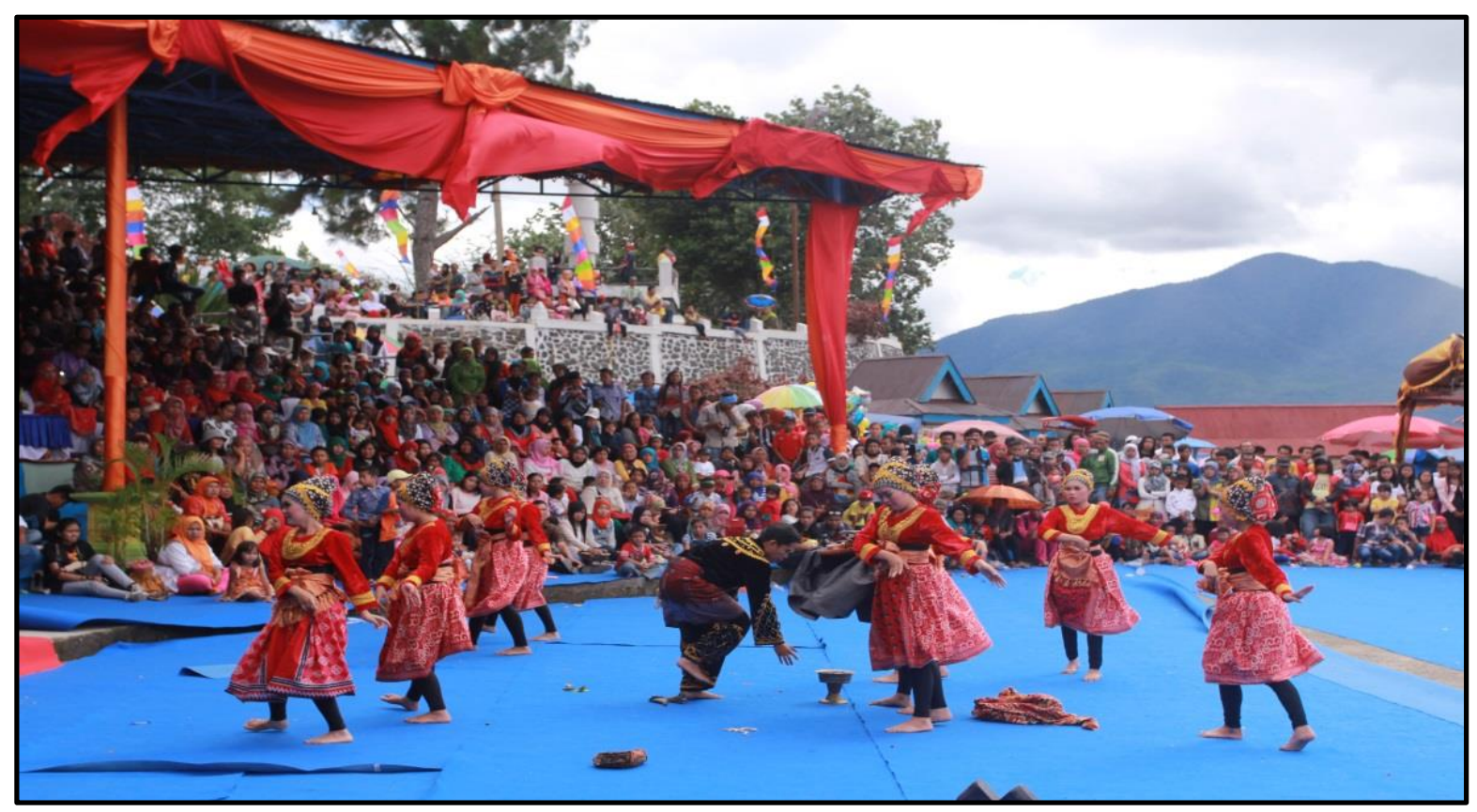

Source; Author's Photo

Picture 17 One of traditional dances is performing at Lake Kerinci Festival in 2014

The event provides multiple benefits for the regions, especially for the local people living in Sanggaran Agung Village. In the future, the event may involve the participation of many stakeholders in an effort for the communities to collaborate with the local government, as well as small- and medium-sized enterprises to gain a higher profit. However, the empirical study indicated that the local government was unable to capitalize on opportunities for promoting the festival. Most of tourist locations in Sanggaran Agung are natural panoramic scenes such as Lake Kerinci, Belang Cave, Kelelawar Cave, waterfalls, and the forest cultivated with cinnamon and tea plantations (Tourist Office of Kerinci Regency, 2014). Those locations have a very high potential for developing ecotourism in the region.

There are many benefits to the local economy with respect to the cultivation of cinnamon in customary and state forests. Local people have established home enterprises which utilize cinnamon as a raw material for cinnamon oil, syrup, chips and other products. As with the other villages in this study, Sanggaran Agung has few conflicts which are related to the management of the natural conservation area. The location of residential and plantation areas are not adjacent to the conservation area in KSNP. The village is bordered 
by the customary forests and state forest. It would there be very beneficial and provide great opportunities if the surrounding area could be managed by local people and the local government rather than only by KSNP.

The population of Sanggaran Agung is mostly made up of the indigenous people of Kerinci, with less than $10 \%$ of the ethnic population coming from Minangkabau, Batak and Java. Unlike communities in Lempur Tengah, people in Sanggaran Agung are not interested in establishing the area as an indigenous village. According to several of the respondents, this general lack of interest has been caused by the growing home industries for cinnamon products. Therefore, small and medium enterprises (SMEs) which utilize cinnamon seem more prosperous than ecotourism. Another reason for this general lack of interest is the overall lack of knowledge about tourism and its utilization.

"Communities prefer to farm and to build upon the home industry of cinnamon products. They also do not know how to develop and utilize ecotourism opportunities"' (Respondent 30, Staff at the office of Tourism Kerinci Regency).

In this regard, the Tourism Office has been collaborating with the KSNP authority in an effort to encourage locals to help in the development of ecotourism and to build awareness about maintaining KSNP. One of the programs was training local people to serve as tourism guides. The outcome of this program has been a common understanding and good cooperation among stake holders. Other programs that have been developed to support tourism development have been especially focused on building infrastructures, for example toilets, walking paths and other things that may make it easier for visitors. The most important aspect is to build infrastructure and establish a code of ethics involving a traditional leader and customary law.

\subsubsection{Lindung Jaya Village: tea plantations and Mount Kerinci as interesting attractions.}

The village of Lindung Jaya, part of Kayu Aro Sub-district, is located 3 kilometers from the entrance gate of Mount Kerinci with the majority of people being Java ethnicity. Most of the local people are farmers who cultivate horticulture-based crops such as potatoes, corn and cassava, as well as raise cattle. The cultivation area is located around Mount Kerinci, with some of this cultivation land being located in the conservation area of KSNP; furthermore, the land has been used by the community for a long period of time. Despite the land overlapping with the conservation area, the community has continued cultivation in the 
area because there is no clarity to move it. The reminder for local people is forbidden to cultivate further in the conservation area in Mount Kerinci. The other reason is due to unclear borders between the conservation and cultivation area.

Lindung Jaya does not have as many tourist attractions as the other villages considered in this investigation. Most of the village is located on the state owned tea plantation (Perseroan Terbatas Perkebunan Nusantara VI/PTPN VI), with most of the community members working as tea pickers. However, tourists that come to climb Mount Kerinci influence the communities and their knowledge about the ecotourism opportunities around them. The communities are aware that there are two popular destinations near the village: Mount Kerinci and Lake Gunung Tujuh, as well as Telun Berasap Waterfall and local caves. Several of the ecotourism attractions in Kayu Aro are listed in Table 30.

Table 30 Ecotourism destinations, attraction types and the organizer

\begin{tabular}{|c|c|c|c|}
\hline No & Name of destination & Type of attraction & Organizer \\
\hline 1 & Lake Belibis (Kersik Tuo) & Natural panoramic, $45 \mathrm{~m}$ & the KSNP authority \\
\hline 2 & $\begin{array}{l}\begin{array}{l}\text { Mount } \\
\text { Tuo) }\end{array} \\
\text { Kerinci }\end{array}$ & Natural panoramic, $3,085 \mathrm{~m}$ & $\begin{array}{l}\text { the KSNP authority } \\
\text { Office of culture and } \\
\text { tourism }\end{array}$ \\
\hline 3 & $\begin{array}{l}\text { Flower park of Asri Murni } \\
\text { (Kayu Aro) }\end{array}$ & $\begin{array}{l}\text { Natural panoramic, an area } \\
1400 \mathrm{~km}\end{array}$ & $\begin{array}{l}\text { Office of culture and } \\
\text { tourism }\end{array}$ \\
\hline 4 & $\begin{array}{l}\text { Batu Tongkang (BLK II } \\
\text { Kayu Aro) }\end{array}$ & $\begin{array}{l}\text { Natural panoramic, altitude } \\
500 \mathrm{~m}\end{array}$ & $\begin{array}{l}\text { The State owned tea } \\
\text { plantation VI }\end{array}$ \\
\hline 5 & Tea plantation (Jayu Aro) & Agro-tourism, 5,200 ha & $\begin{array}{l}\text { The State owned tea } \\
\text { plantation VI }\end{array}$ \\
\hline 6 & $\begin{array}{l}\text { Aroma Pecco (Bedeng } \\
\text { Delapan) }\end{array}$ & Natural panoramic, 10 ha & $\begin{array}{l}\text { Office of culture and } \\
\text { tourism }\end{array}$ \\
\hline 7 & River Sangir & Natural panoramic & The KSNP authority \\
\hline 8 & $\begin{array}{l}\text { Swamp Bento (Kersik } \\
\text { Tuo) }\end{array}$ & Natural panoramic & The KSNP authority \\
\hline 9 & $\begin{array}{l}\text { Swamp Ladeh } \\
\text { (Kebun Baru) }\end{array}$ & Natural panoramic, 3,150 ha & The KSNP authority \\
\hline 10 & $\begin{array}{l}\text { Waterfalls Pauh Tinggi } \\
\text { (Pauh Tinggi) }\end{array}$ & Natural panoramic, $4 \mathrm{Ha}$ & The KSNP authority \\
\hline 11 & Cave Kasih (Kayu Aro) & Natural panoramic, 1,400 ha & The KSNP authority \\
\hline
\end{tabular}

Source: Tourism Office of Kerinci Regency, 2014 
The majority of ecotourism destinations are located in Kayu Aro and most of them are in the conservation area of KSNP. Natural panoramic views are very common in this area and are mostly managed by the KSNP authority. Conflict has occurred in some instances with regard to the management of ecotourism opportunities, specifically among the local government, the office of Culture and Tourism and the KSNP office. For communities in Kayu Aro, including people in Lindung Jaya, it is not particularly important who the organizer of these tourist destinations is; the most important thing is that they are provided with inputs and infrastructures for their cultivation, such aspects may include fertilizer subsidies or improving delivery capabilities so that they can market their products in Sungai Penuh city and West Sumatra province.

Based on the empirical study and the in-depth interviews, Lindung Jaya Village does not have specific attractions for ecotourism. However, they recognize many opportunities, for example through providing tourist guides or building small hotels in nearby locations. Currently, there are three hotels in Lindung Jaya that are suitable for tourists and climbers; however, there is a general lack of sufficient facilities. From the hotels, the visitors can see beautiful panoramic views of Mount Kerinci. For local people, there are other potential destinations that need to be considered such as the tea plantation which is known as Aroma Pecco. Views of the tea plantation can be enjoyed from many spots throughout the area.

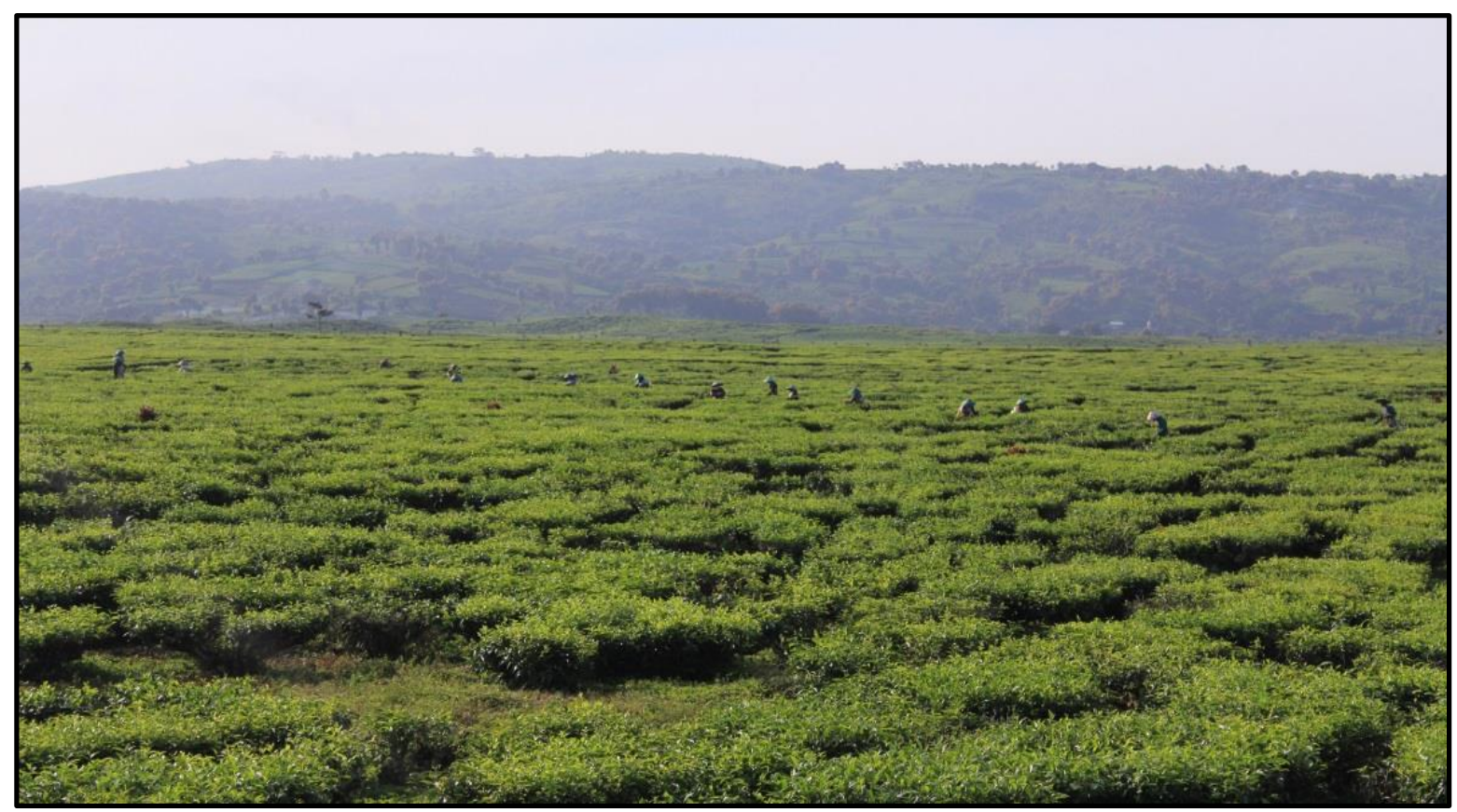

Source: Author's Photo

Picture 18 Tea pickers are picking tea leave in the state owned plantation in Kayu Aro 
Despite the potential for ecotourism, there is no direct benefit to the local communities because of the existence of Mount Kerinci ecotourism icon both in the local and national levels. This is contradictory to the benefits achieved from some of the mountains in other regions, such as Mount Gede Pangrango in West Java, Mount Semeru and Mount Bromo in East Java, which have a significant effect on the improvement of the local economy. It may be that the local government lacks the necessary experience to promote Mount Kerinci as the highest mountain on the island of Sumatra and the second highest in Indonesia. The KSNP authority also fails to maximize the potential for ecotourism in KSNP.

\subsubsection{Pelompek Village: managing the entrance gate and tourist guides entering Lake Gunung Tujuh}

The Pelompek Village is adjacent to the conservation area of KSNP. As mentioned in Chapter 5, illegal logging occurs mostly in this Village. The primary ethnicities in this village are Minangkabau and the origin people of Kerinci. The majority of community members are farmers who need land for plant cultivation. Some farmers have changed their cultivation patterns from perennial crops like cinnamon to horticulture-based crops influenced by the cultivation systems in other communities in Kayu Aro. Horticulture cultivation realizes greater profits than cinnamon production.

Lake Gunung Tujuh is a very attractive site for tourists and nature lovers. Furthermore, local people are interested in being responsible for the management of the area's ecotourism opportunities. Members of the local communities know how to reach the attractions and not only act as tour guides, but also help to manage the parking area at the entrance gate of Gunung Tujuh. Initially, the manager of KSNP did not agree that communities should be permitted to manage tourist destinations, in an effort to avoid vertical conflicts, the KSNP manager and local people established a local group of nature lovers with the communities being granted management of the parking area, as well as cleaning and maintaining the area surrounding Gunung Tujuh. Gunung Tujuh is relatively more crowded than Mount Kerinci because the location can be reached within three hours through a relatively flat track from the entrance (Pelompek Village). Tourists are allowed to camp in Gunung Tujuh, leading to a more natural experience. Furthermore, a beautiful and unique view is present, for example that of the full moon which is a favorite for visitors staying in the area. Moreover, visitors are able to enjoy Lake Tujuh in the utilization zone. Although there are not as many destinations in this village, destinations in Gunung Tujuh 
tend to be more crowded than those in the other villages. The most popular attractions in the village are Lake Gunung Tujuh, Telun Berasap Waterfall and Putri Dian Suryani Waterfall.

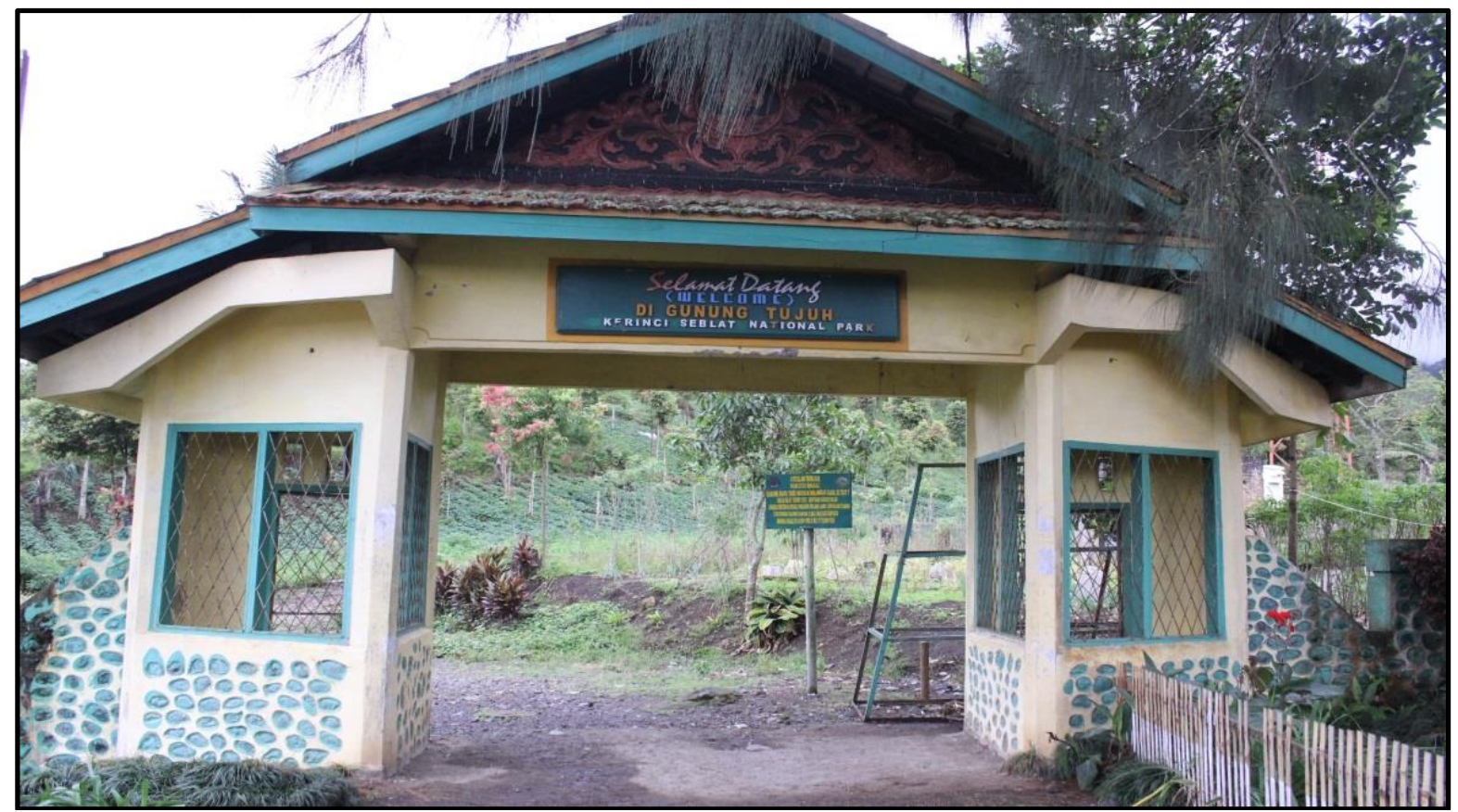

Source: Author's photo

Picture 19 The main entrance of Lake Gunung Tujuh located in Pelompek Village

The path to Lake Gunung Tujuh is itself an interesting attraction for ecotourists due to the presence of endemic plants and animals. Unfortunately, most visitors are unaware of this opportunity because the KSNP staff does not inform them about the extensive existence of biodiversity. The staff worries that visitors may damage the area because they do not care about the importance of the plants and animals, or may try to hunt while they are in the area. Lack of awareness regarding the region's biodiversity may actually be more detrimental to the area's ecology and ecosystems. This is evidenced by the continuing encroachment of people into the conservation area which frequently harms rare plant species and repels protected animals from their natural habitats; if more awareness is spread to biodiversity, some of this may be stopped. Interestingly, the willingness of local communities to participate in the management of ecotourism attractions has not found a satisfactory response from the KSNP management. The local government, however, is prepared to facilitate the improvement of awareness for biodiversity conservation, training local community to be tourist guides and security for visitors, dissemination of information to the communities about the rules related to the use and management of natural resources and the establishment youth and local organizations. 


\subsection{Developing ecotourism to improve the economy and protect the sustainability of the area}

In developed countries, particularly those of Western Europe, national parks and other protected areas are maintained as a 'living landscape' with a diverse range of utilization. Living landscape in Kerinci Regency means that the area provides tourism facilities, as well as maintains personal residences, livelihoods, land (farming) and roads which can be utilized and further contribute to communities' welfare. However, there are both positive and negative impacts that result from maintaining a living landscape. Tourism provides many opportunities for both national park management and local entrepreneurs. On the other hand, it can result in some negative impacts on the local environment, such as pollution and changes local values and norms.

Issues related to land use in the protected areas of KSNP have long existed. The conservation areas are the forefront in the protection of the region's biodiversity. In 1997, the Commission on Environment and Development (COED) proposed that $12 \%$ of the terrestrial surface area in the region be kept as a conservation area to represent all types of biomass (Gossling, 1999). However, the local people have utilized this area for a long period of time and continue to use the conservation area as a source of livelihood.

\subsection{National design and administration for the development of ecotourism in KSNP}

The Regulation of the Minister of Forestry, No P.03/Menhut-II/2007 concerning the Organization and Technical Implementation Unit of National Parks, defines the Programs of Biodiversity and Forest Protection. Furthermore, the programs cover the development of essential ecosystems and encourage the empowerment of protected forests, investigation and forest protection, conservation of species, controlling forest fires, development of environmental services and natural attractions, supporting management, and the implementation of other tasks of the Director General of Forest Protection and Natural Conservation. With regards to the regulation, KSNP is an area intended to protect ecosystem, preserve the biodiversity of genetic resources, support education and research, and develop culture and cultivation practices. Table 31 shows the percentage of successful implementation for each task offset by the KSNP authority in 2013. 
Table 31 Percentage of successful implementation set by the KSNP authority in 2013

\begin{tabular}{|c|l|c|}
\hline No. & \multicolumn{1}{|c|}{ Activity } & $\begin{array}{c}\text { Percentage of successful } \\
\text { implementations (\%) }\end{array}$ \\
\hline 1 & $\begin{array}{l}\text { Development of essential ecosystems and } \\
\text { empowerment of protected forests }\end{array}$ & 91.74 \\
\hline 2 & Investigation and forest protection & 86.65 \\
\hline 3 & Conservation of species and genetic diversity & 96.25 \\
\hline 4 & $\begin{array}{l}\text { Development of environmental services and natural } \\
\text { attractions }\end{array}$ & 97.60 \\
\hline 5 & $\begin{array}{l}\text { Controlling forest fires } \\
\text { tasks }\end{array}$ & 95.28 \\
\hline 6 & $\begin{array}{l}\text { Supporting management and implementing other } \\
\text { ang }\end{array}$ & \\
\hline
\end{tabular}

Source: The KSNP authority, 2014

As shown in Table 31, developing environmental services and natural attractions was a relatively successful endeavor in 2013 with $79.60 \%$ of these efforts being achieved. Moreover, this success means that the KSNP authority realized several great opportunities for ecotourism in KSNP. However, one problem associated with increasing ecotourism activities is the extended involvement in the management efforts, particularly involving multiple stakeholders, especially local governments and communities, which often leads to increased conflict. Another obstacle is that ecotourism attractions lie mostly within the conservation area, which implies that the destinations cannot be managed by actors outside the KSNP area. The KSNP authority has been successful in developing and maintaining the conservation and protected areas, however, with a successful implementation rate of $91.75 \%$, which is more than any of the activities intended to develop ecotourism. It can therefore be stated there are inherent linkages between biodiversity conservation and ecotourism.

There are 22 ecotourism destinations located in the conservation area of KSNP, which are spread across four provinces: Jambi, West Sumatra, South Sumatra and Bengkulu. Table 32 describes the ecotourism attractions within the KSNP area, especially those in Kerinci Regency. 
Table 32 Tourist destinations in the KSNP conservation area in Jambi Province

\begin{tabular}{|l|l|l|}
\hline No. & Name of ecotourism attraction & Location (Regency) \\
\hline 1 & Lake Gunung Tujuh, Lake Duo, and Lake Belibis & Kerinci \\
\hline 2 & Lake Depati Empat, Lake Ceram and Lake Kumbang & Merangin \\
\hline 3 & Telun Berasap Waterfall & Kerinci \\
\hline 4 & Mendikit Waterfall and Sungai Mentilin Waterfall & Merangin \\
\hline 5 & Cave Kasah & Kerinci \\
\hline 6 & Mount Kerinci, Mount Tujuh and Mount Raya & Kerinci \\
\hline 7 & Sitinjau Laut Hill and Kayu Embun Kerinci Hill & Kerinci \\
\hline 8 & Mount Masurau, Mount Nilo and Mount Sumbing & Merangin \\
\hline 9 & Ladeh Panjang Swamp and Bento Swamp & Kerinci \\
\hline 10 & Bukit Tapan natural panoramic & Kerinci \\
\hline 11 & Batang Merangin River & Kerinci and Merangin \\
\hline 12 & Grao Solar, Grao Sakti and Grao Kunyit & Merangin \\
\hline
\end{tabular}

Source: The KSNP authority, 2014

The field survey and in-depth interviews conducted for this study show that there are many popular ecotourism sites for visitors in the Kerinci region, namely Mount Kerinci, Lake Gunung Tujuh, Ladeh Panjang Swamp, Mount Masurai, Telun Berasap Waterfall and the Bukit Tapan panorama view. These popular ecotourism locations are briefly described as follows (Bulletin Kerinci, 2012):

\section{(1) Mount Kerinci}

Mount Kerinci is the highest peak on the island of Sumatra and the highest active volcano in Indonesia with a height of $3,805 \mathrm{~m}$. Entrance to Mount Kerinci can be done by passing through the official gate which was built by the KSNP manager; Entrance 10 which lies approximately $5 \mathrm{~km}$ from Lindung Jaya. The temperature at the peak can reach $0^{0}$ Celsius, with an average temperature ranging from 5 to $10^{\circ} \mathrm{C}$. The climbing paths to reach the peak are provided and maintained by the manager of KSNP. Along this path, there are some shelters for climbers and visitors to rest.

\section{(2) Lake Gunung Tujuh}

The trip to Lake Gunung Tujuh takes 4 hours on foot from the main entrance. Lake Gunung Tujuh is a unique place because it is located in the middle of Gunung Tujuh 
and has an altitude of 1,960 $\mathrm{m}$. The lake was formed over time by volcanic activity; Lake Gunung Tujuh is separated by valley from Mount Kerinci. The lake is one of the main biodiversity centers in KSNP with various rare plants and wild animals, in addition to a very beautiful natural presence.

\section{(3) Ladeh Panjang Swamp}

The Ladeh Panjang swamp is located on a mountainous area with an altitude of 1,950 m. It takes an average of one hour to reach the swamp from Sungai Penuh, and passed through the Kebun Baru village. From this village, however, visitors walk for 7 hours to reach the swamp. The Ladeh Panjang swamp serves as the habitat of many wild animals. Therefore, the location is the perfect place to develop and maintain wildlife.

\section{(4) Mount Masurai}

Mount Masurai has a peak altitude of 2,720 m. This location can be reached in 6.5 hours when traveling from Bangko city, the capital of Jambi Regency. Bangko is near Sungai Penuh, which is the capital of Kerinci Regency. Mount Masurai is primarily forest with a canopy-rise, as well as home to many rare and ornamental plants, like Kantung Semar, and wildlife.

\section{(5) Telun Berasap Waterfall}

Telun Berasap Waterfall is not far from Lindung Jaya and Pelompek villages. The waterfall does not meet the technical requirements to be considered as an ecotourism destination because the location is more appropriate for outdoor recreation than ecotourism. However, its potential is promising with regards to influencing economic improvement for the surrounding community. These opportunities, however, have not been fully authorized for local people, local government and the KSNP manager.

\section{(6) Bukit Tapan Panorama}

Access to the Bukit Tapan panorama view is relatively easy, since visitors can use different types of vehicles that take a travel time of roughly 40 minutes from Sungai Penuh city. Visitors are required to obtain permission from the manager of KSNP to enter this area. The panoramic view is a favorite location for bird watching due to the wide variety of rare bird species in this area. Moreover, there are also habitats for various species of primates, Sumatran tigers and rabbits. The surrounding forest is a rainforest encompassed in low and high mountains. The road infrastructure for this location is good due to the highway connecting the provinces of West Sumatra and Jambi. 
There are two government mandating regulations in place related to entering the conservation areas. These regulations are the Regulation of Director General of Natural Conservation No. P.7/IV-SET/2011 on procedures to enter the natural reserve area, the Natural Conservation Area and Game Forest, and Government Regulation 59 of 1998 regarding to the Tariff on Non-Tax Revenues at the Ministry of Forestry and Plantation Jo PP 741999 dated August 10, 1999 regarding Tariff on Non-Tax Revenues at the Ministry of Forestry and Plantation. First, visitors participating in non-tourism activities such as research, education, expedition, retrieval snapshoot, film documentation, training and advertising must get a permit to enter the conservation area, known as a Surat Ijin Masuk Kawasan Konservasi (SIMAKSI).

Second, visitors who enter the conservation area for tourism purposes must pay the entrance fee. The admission price has been determined in accordance with the regulations and is set as: 1) IDR. 2,500 (\$ 0.25) for Indonesian visitors, 2) IDR 20,000 (\$1,5) for foreigner tourists, 3) Free of charge for visitors who are recognized as a cadre of conservation. Charges are also added on for carried goods such as cameras IDR $5000(\$ 0.5)$ and recording equipment IDR 125,000 (\$12.5) for domestic tourists; for international tourists these fees are IDR 50.000 (\$5) for a camera and IDR. 125,000 (12.5) for a mobile phone with a camera. The KSNP manager has appointed the branch offices of KSNP in Sungai Penuh, Padang, Bangko and Curup to serve as the entrance locations for non-tourism activities. Several locations, such as the offices in Mount Tujuh, Mount Kerinci and Sulap Hill, are designated to provide entrance for tourism purposes.

Income obtained from the entrance tickets is directly deposited into the state fund as non-tax revenue. During the period of 2011-2013, non-tax revenues as a direct income of KSNP increased as described in Figure 5: in the same period, a substantial fluctuation occurred in KSNP with respect to the number of visitors, as shown in Figure 6. 


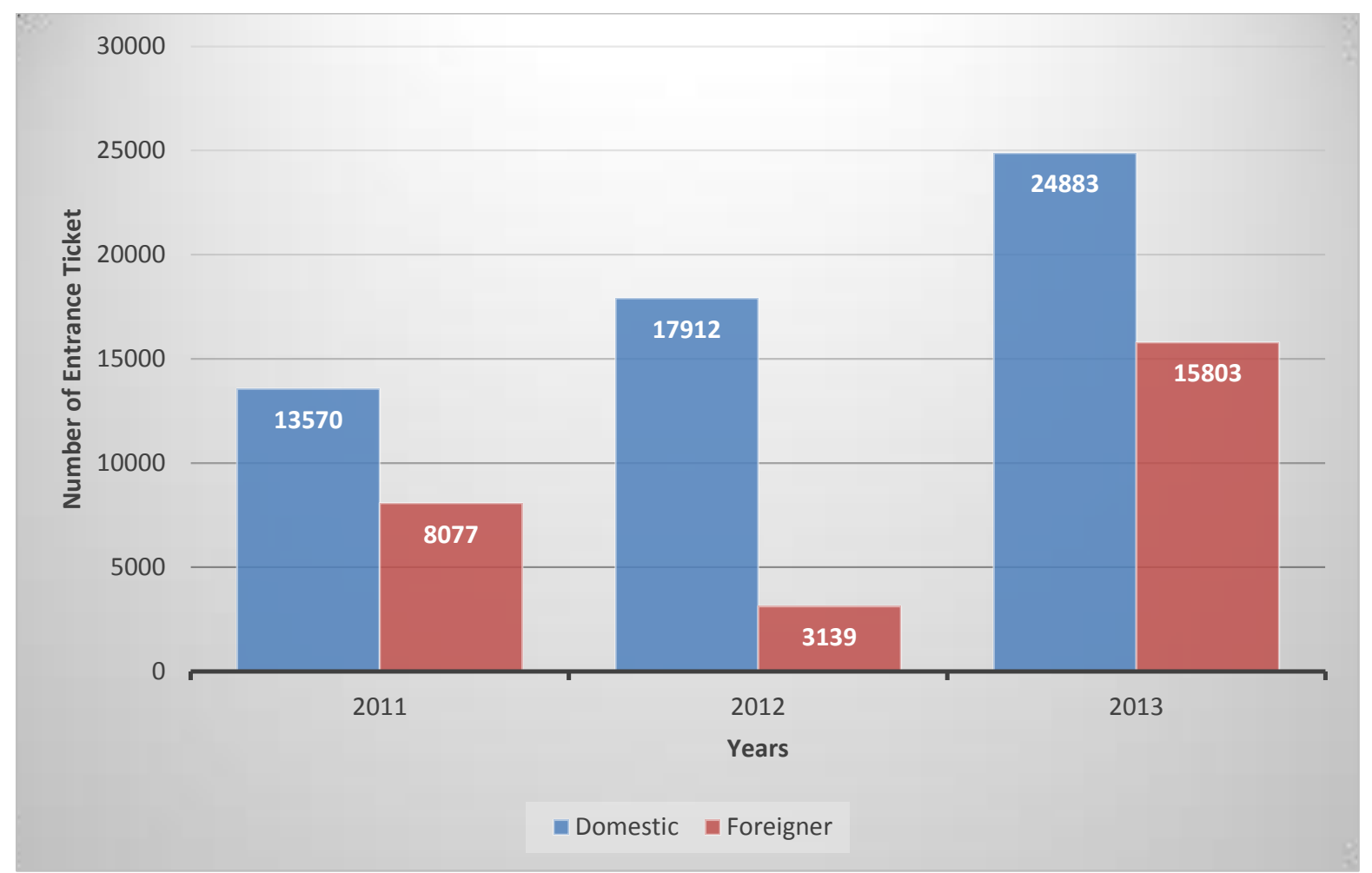

Source: The KSNP authority, 2014

Figure 5 Non-tax revenues of the KSNP authority, 2011 to 2013

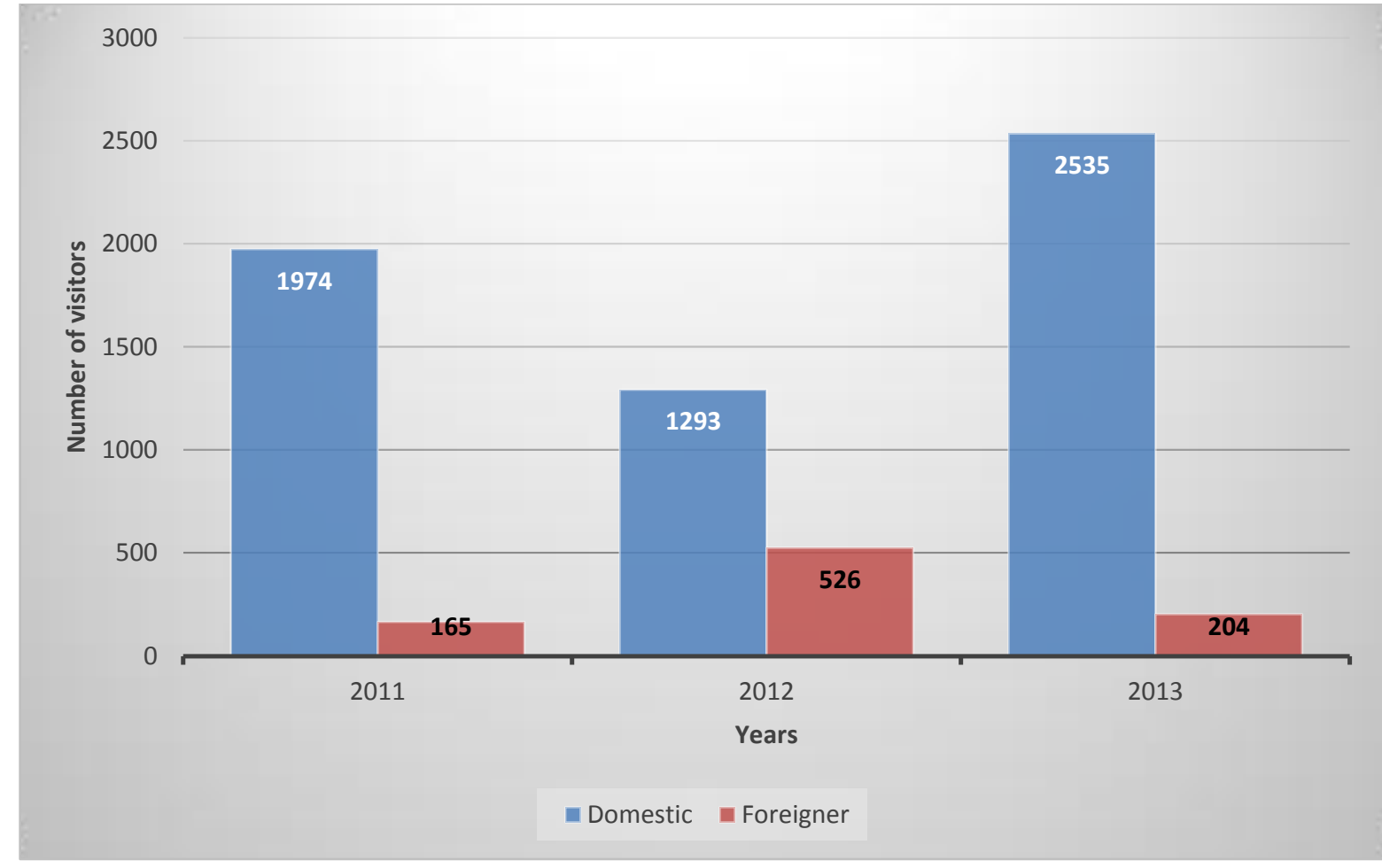

Source: The KSNP authority, 2014

Figure 6 Number of KSNP visitors from 2011-2013 


\subsection{Local governments efforts to create ecotourism destinations}

In the past, tourism has not been a priority sector in the regional development strategy put in place by the government of Kerinci Regency despite the abundant natural resources and rich ecotourism attractions. In order to fully maximize these opportunities, the local government needs to focus more on the development of infrastructures, human resources, local economic competitiveness, democracy, good governance, and quality of management and conservation. The tourism activities are limited to tourism promotion as the priority program.

One of the primary objectives of the local government, through the Office of Tourism, is the promotion of tourist attractions, including those related to ecotourism destinations and their respective facilities. Most tourist destinations in the region are located in the following villages: Lindung Jaya (Kayu Aro Sub-district), Pelompek (Gunung Tujuh Sub-district), Lempur Tengah (Gunung Raya Sub-district) and Sanggaran Agung (Danau Kerinci Subdistrict). Consequently, there are often conflicts of interest among the local governments, local communities and the KSNP authority. The local government is interested in managing these locations, even those within the core zone of KSNP due to the potential that these attractions provide for the increase of economic welfare within local communities. The government intends to involve traditional institutions, community associations and youth associations to manage and maintain the sites.

Some of the tourism promotion activities are carried out by the local government in collaboration with the indigenous people, the tourism office of Jambi province. These activities frequently cover workshops on tourism awareness in order to generate great ideas that can be used for the management of natural resources and to facilitate local communities and the staff of the KSNP authority.

\subsection{Problems with ecotourism management}

\subsubsection{Biodiversity management}

The problem often arising among the local communities, local government and national agencies is related to access to the utilization of biodiversity within the KSNP region. The regulation of the Director General of Forest Protection and Natural Conservation No. 077/IV-KK/2007 assigned the Head of the KSNP authority to manage the zones within the KSNP region. The zones include the core zone, wilderness zone, utilization zone, rehabilitation zone, specific zone, and traditional zone; unfortunately, information and 
awareness related to these zones and their distinct purposes have not been clearly relayed to the local people.

There is also a lack of coordination among the local government, the Office of Forestry and Plantation, and the manager of KSNP, especially regarding programs associated with sustainable natural resource protection and prevention. This lack of coordination therefore influences economic and political interests. Negative economic activities such as illegal logging and hunting of wildlife are a continual threat in the region. Political interests in the management of the conservation area are a trending issue related to the election of a regional head, but this was only done for political rhetoric. On the other hand, the KSNP authority argued that their office is understaffed and is therefore unable to properly control and manage the region's biodiversity.

The issuance of natural resources utilization permits is another significant problem among actors. Conflicts of interest have arisen because the authority is the only party that may issue ecotourism entrance tickets. Thus, any ticket provided to tourists by local people is considered to be illegal, even though some parts of the KSNP area lie within the customary forest.

"If we look at licensing, we often notice that illegal logging is taking over the protected forest; these loggers appear to be licensed, and none of the authorities impose punishment. However, if local people are caught in actions deemed to be illegal logging, they are directly put into the cell. It is not fair in this case. Obtaining a letter of permit for a company is done very quickly. In contrast, for community members, the process is very slow. Indeed, KSNP is still lacking in terms of supervision, but it can be prevented through good cooperation between the KSNP official and the local people"' (Respondent 52, Jambi provincial government staff).

\subsubsection{Ecotourism planning in Kerinci Seblat National Park}

Maintaining the conservation area and promoting ecotourism in KSNP is a concern for all involved institutions. However, there is no integration among stakeholders that helps to maintain and improve ecotourism packages. Each institution acts according to its own ideas with little considerations of the others. In several ceremonial moments such as traditional cultural performances, festivals and other activities cooperation among them were done for this event. 
Actually, the national and local governments have several good strategies in place for the future. On the national scale, the manager of KSNP has developed several annual programs for conservation and development of the essential ecosystem, species and genetic conservation, environmental services and natural attractions. For example, creating site plans for tourist destinations in KSNP, developing the destinations of KSNP, coaching a group of nature lovers, fostering conservation cadres for beginner and advanced levels, providing a conservation camp, coaching the Kerinci Bird watching Club (KBC). The local government, through the Office of Tourism and the Office of Forestry and Plantation, has initiated several tourism and natural preservation events such as the Festival of Lake Kerinci to promote the tourist attractions and biodiversity in Kerinci Regency. The local communities in the four villages have their own cultures which they readily communicate with younger generations in order to ensure continuous maintenance of the Kerinci forests.

In implementation, however, there have been conflicts of interests among stakeholders, including some issues which institutions intended to manage, utilize and prosper from such activities. For example, the issue related to the entrance ticket was a source of conflict amongst the agencies. The main problem in the northern part of Kerinci, including the villages of Pelompek and Lindung Jaya, was encroachment of protected areas. It is often difficult when differences in perceptions occur between the local communities and the manager of KSNP.

A good example of ecotourism management is in the village of Lempur Tengah, where a successful collaboration between the local community and the local government has led to effective management of the destination in the area. The local community in Lempur Tengah has greater authority to manage the tourist destinations than many other villages; however, the KSNP officials object when they are not involved in managing the area due to concerns regarding the conservation of biodiversity.

\subsubsection{Community participation}

Increasing public participation is one of the greatest dilemmas for managing ecotourism in the KSNP area. Limited access to conservation land use for stakeholders is also a significant obstacle. Local communities, indigenous people, and the local government support the development of the potential for ecotourism; their efforts, however, have been constrained by the regulations put in place by the authority which prohibit anyone from utilizing the protected region. On the other hand, the authority has had a difficult time in applying the conservation rules as a result of an increasing number of forest encroachment 
cases. Moreover, an appropriate, win-win solution has not yet been found regarding community participation, especially in the conservation area

Kerinci Regency has many tourism attractions which are not widely known throughout the Indonesian society. Therefore, the participation of local communities becomes an important element in helping to promote these attractions. An expected outcome of participation is that local people will be more willing to help and take an active role in the management efforts and will finally realize the importance of conservation. The local government and local communities hold the opinion that the KSNP authority should involve the community members in management efforts. Differences in perception among stakeholders should be used as a stepping stone to improve prosperity in society and establish a balance between utilizing the interesting attractions and nature.

\begin{abstract}
'So far we have seen that KSNP only preserve forests and invite the public to maintain the area without offering any compensation. The compensation can be interpreted as a form of cooperation between KSNP and the communities. Compensation is not only in the form of money, but also in the form of fulfillment of for required good, such as seeds, fertilizer, and daily good. If the budget is limited, KSNP can ask communities to join in some activities, such as becoming tour guides or selling souvenirs to help attract visitors" (Respondent 51, Head of Community Empowerment and Tourism, Kerinci Regency).
\end{abstract}

\title{
7.6.4. Implementation of policies
}

Implementation of agreements and policies are still an obstacle for stakeholders regarding the development of ecotourism activities. The local community holds the perspective that only the local government and a local NGO have supported them in their desire to utilize ecotourism locations within the conservation area. An agreement between local people and the KSNP authority was made, but has not been overly effective. In this context, the authority worries that such activities will damage the conservation area. Furthermore, the manager of KSNP held the impression that adverse events occurred in the area when local communities permitted visitors to enter the conservation area.

The local people, however, believes that KSNP has frequently broken promises with respect to the implementation of the agreed upon programs and plans. Other stakeholders feel that KSNP has failed to fully communicate with the local communities about the programs and regulations related to the utilization of natural resources. 
' 'The KSNP authority has not evenly distributed the socialization program; this is proven by the fact that a lot of people do not understand and tend to violate the rules. The local people cannot be blamed if the government is still not able to provide knowledge and prosperity to the people. For the KSNP party, there are many good programs and plans, but implementation was not really good" (Respondent 50, Section Head of Tourism Government of Jambi Province). 


\section{Chapter VIII. Developing Collaborative Management: Modelling, Obstacles and Opportunities for Collective Action among Stakeholders}

Continued conflicts of interest, along with unresolved designation of management in the Kerinci region is due to the opposing viewpoints of the various actors, specifically between local people and national park authority. Nonetheless, collaborative management is an approach that has the potential to provide many advantages to the situation, particularly increased effectiveness of management, greater acceptability of management actions, enhanced understanding of natural and human systems, increased trust between government agencies and stakeholders, reduced enforcement expenditures and transaction costs, and increased public awareness of conservation issues (Pinkerton, 1989; Borrini-Feyerabend, 1996; Schusler, T.M., Decker, D.J, Pfeffer, M.J., 2003).

According to the current empirical study relating to Kerinci Seblat National Park (KSNP), there are many differences in the perspectives of the two main actors (local people and the KSNP authority) regarding the management of natural resources within the conservation area. Either the local people or the park authority has realized that each party has the power to recognize the management and mastery access to natural resources. The park claims they have de jure property rights, while members of the local people assume that they have de facto property right as a result of their long settlement history the surrounding area. This difference in perspective generally occurs in all of the effected regions, but especially in areas where people inhabited the land before it was designated as a conservation forest area (Burkard, 2007; Mehring, et al., 2011).

Furthermore, another problem arises regarding the approach of the national parks which tends to be less focused on programs and targets. The approach of the park is mostly to assume power over the local people. The activities that have been done though persuasive but the message of the activity that would be delivered is the public should be aware of their actions in the utilization of forests in its surroundings is a violation of law. If a member of the local community, or any another resource user, goes against regulation, then they would be accused as a destroyer a protected forest and must be subject to applicable law.

This chapter focuses on developing an appropriate model among the stakeholders, determining kind of obstacles to develop collaboration between the actors and describing the conditions that support the establishment of a collaborative management approach according to the results of the empirical study. 


\subsection{Modelling collaborative management action}

Synthesizing the results of field studies from a variety of perspectives related to collaborative management of natural resources is a process that can help to build a model or framework which bridges the gap between previous ideas (literature study) and recently obtained evidence (empirical study). Figure 7 illustrates the results of this synthesis. The main stakeholders studied are the local community and the government agencies. The aim of the investigation was to determine the stakeholder's perspectives regarding the building of a collaborative management of natural resource among them. Furthermore, this study investigated four selected villages as the location of the study such as Lempur Tengah Village, Lindung Jaya Village, Sanggaran Agung Village and Gunung Tujuh Village, as well as a general overview of the local government of Kerinci Regency as a whole. Representing the agency of the national government is the KSNP authority which is the manager of Kerinci Seblat National Park (KSNP).

Based on the perspectives from respondent about the two major stakeholders (the local community and the park manager), there are some necessary criteria for modelling a co-management approach. The criteria consists of the pattern of collaboratively managing with all actors involved, considering the pattern of participation, power sharing and the implementation of process. 


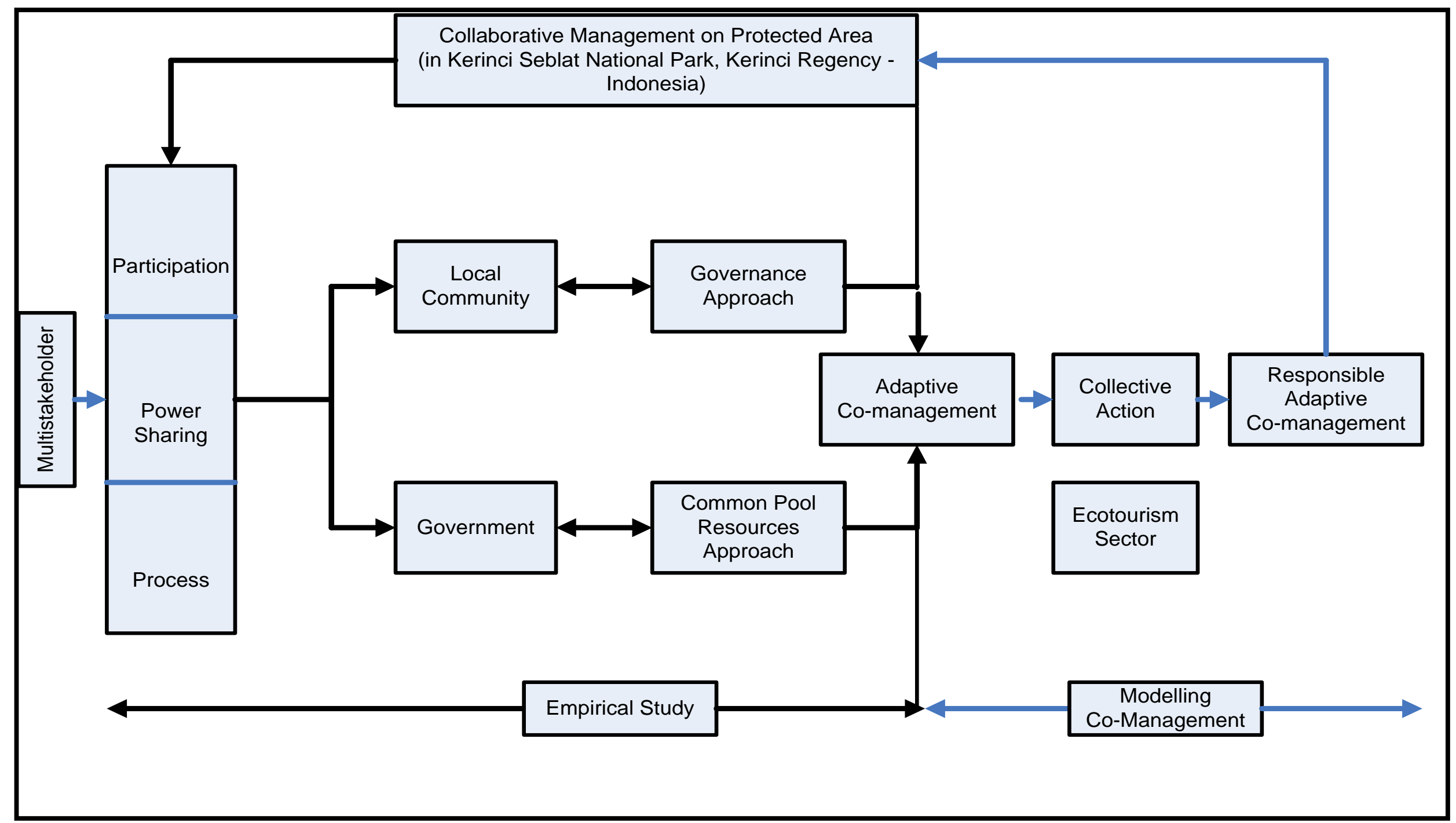

Figure 7 The modelling of responsible-adaptive co-management from the empirical study 


\subsubsection{Managing collaboration}

The collaborative management should be done with the emphasis on the function instead of the structure. If co-management established and carried out in accordance with the structure, implementation is likely to ignore the functional side. Instead, collaborative management is an organization or institution in which the ongoing problem-solving process, not a fixed state, implemented, involving extensive consultation, negotiation and learning together in problem solving network (Carlsson and Berkes, 2005).

With the understanding that managing natural resources should be made functional collaboration, the study of co-management should emphasize how the various management tasks are organized and distributed with respect to function, not structure. Such an approach has the effect of highlighting the result of the division of power, and not the starting point (Carlsson \& Berkes, 2005).

Hence the emphasis on the function of collaborative management and power sharing are the results, the study of collaborative management of the environment should be the emphasis is no longer on the role or regulations related to the results of an ongoing collaboration, but the emphasis is on awareness should be grown. The focus of comanagement is an interdependent involvement of the stakeholder, separate collaboration of public authorities, private businesses, scientific experts, groups of users and social interest groups, non-governmental organizations and representatives of stakeholders in the particular ecological domain (Bouwen \& Taillieu, 2004).

\subsubsection{Which stakeholders are involved?}

It is not sufficient to rely solely on a scale of actors at the same level to gain a full understanding of the best management approaches for natural resource, but requires local, regional and national agencies and groups to settle the affairs of the abundance of resources ecosystem dynamics of various scale, trends and uncertainties (Berkes, 2008). Collaborative management is a continuous learning process for actors or stakeholders. Therefore, organizational development relates to the concept of determining which actors are allowed to participate as stakeholders. As previously stated, the development of collaborative management organizations is an interdependent involvement of the stakeholder, such as collaboration of public authorities, private businesses, scientific experts, groups of users and social interest groups, non-governmental organizations and representatives of stakeholders in the particular ecological domain (Bouwen \& Taillieu, 2004). 
Based on this field study, there are three factors that are de jure and de facto, the main actor for the co-management of the local community, the park and the local government. The local community is the de facto actor as it has had a long history in the region prior to the establishment of the protected forest areas were designated as a national park. The park administrators make up a party that has a strong legal legitimacy, de jure, to manage and guard the continuity of the existence of the national park. The local government is a party that can be a mediator between the local community and the park in resolving the many disputes related to the utilization of forest areas, although in some cases, the local government tend to favor the local people. This is due to the local government generally feels responsible for the welfare of the local residents, as well as recognizes the associated economic interests and an opportunity to generate local revenue through the use of natural resources.

In addition to the actors listed above, another important factor which needs to be considered for the effective development of co-management is NGOs. It has been shown that the presence of (some) NGOs has direct benefits, as perceived by the local community, in developing the knowledge and improving the welfare of the local communities. This may be related to the two state agencies that are in charge of organizing patterns of co-management in the area of the Kerinci region. For example, there are NGOs that do not only provide guidance to the local community in terms of agriculture, but also serve as a supplier and marketing partner for agricultural commodities. These patterns of the cooperation have had a significant impact on local residents and have improved their confidence for doing co-management.

Each party has a different perspective as to the development constraints of this partnership. The local communities generally choose a governance approach in the development of co-management, with the expectation that the ways of democracy will be more effective in settling disputes. Meanwhile, the park generally prefers the common pool resource (CPR) approach. The park is aware that they have the power de jure, but also face limited manpower to properly manage the area eligible for consideration.

\subsubsection{Participation}

Participation can be described as the managerial techniques implemented on decisionmaking in the organization of the commons, which focus on effectiveness contingencies (Bouwen, 2004). Based on the empirical study, as described in the Chapter 7, the local communities under consideration are four selected villages for this research that have claimed that the land use of the KSNP's a part is due to economic pressures. The land use of the Park is also based on the hereditary right of land ownership, except for the Lindung Jaya Village in the Kayu Aro Sub-district, where expansion plans are motivated by high economic needs. 
Involved in the organization of collaborative management efforts should of course be the three actors most closely affected by the use and management of the national park, namely the local community, the local government and the national park's administration. In addition to these three actors, it is important for NGOs to be involved. These NGOs are often involved in the process of advocacy and mentoring, which can easily be cooperated on by the other three actors. The Lembaga Tumbuh Alami (the LTA) and The Warsi are two examples NGOs that are genuinely accepted in the area at the regional level and the provincial level.

Other parties that may be considered for involvement in the development of collaborative management are travel agents (travel package manager). From the empirical study, it has been determined that the presence of actors from the tourism sector can help to develop collaborative management, because they can act as a mediator for the local community and the national parks in the event of conflict. To be a concern that in the village Lempur Tengah, the presence of actors in the tourism sector would be little role for Lempur Tengah that the local community-led youth are better able to manage the tourism attractions in this area. In Sanggaran Agung, the local government is more dominant in tourist management. By distance from Sanggaran Agung to The capital of Regency, Sungai Penuh city, allows tourists to mobility. Unlike the situation in the two villages in the northern part, Lindung Jaya in Kayu Aro and Pelompek in Gunung Tujuh, the presence of an ecotourism package managers, for instance hotel services, potter, souvenir businesses and tour guides have a more important role than the other actors such as the village goverment or the local community. There are two favorite destinations in these two villages namely Mount Kerinci and Lake Gunung Tujuh.

The issue remains as to how all of the involved actors can be brought together to work towards the same objectives, through collective action which allows all actors to work together. The appropriate approach may either be that of the CPR approach or through various management approaches. The current empirical study indicates a tendency towards the usage of the CPR, predominately by the KSNP managers, for interacting with the community; in this sense, the emphasis is on the need for public awareness of regulations and punishments in the instance of national park law violation. However, the local people recognize that the trend of the local governments is to seek cooperation with the national park manager. There is the desire of the community to prior efforts have been made forcibly to expel a user or regional land encroachers, so that the priority of the park is in coordination with the vertices of society and actors. Furthermore, the national park generally views society as an exogenous factor, in which local people are viewed as destroyers of the national park; this viewpoint often leads to conflict between the two parties. If the potential of conflict is mapped, it can be expected that 
the conflict between the local community and the national park may ensue. While actors such as the local government, even though it should be in the neutral position, it tends to be aligned to the local community, as evidenced in the empirical study. The governance-based perspective is preferred to be done.

\subsubsection{Power sharing}

Power sharing within the framework of co-management is the end of the process, not the starting point (Carlsson \& Berkes, 2005). Associated with the development of inter-multistakeholder co-management, it is not uncommon for research, including the current study, to find evidence of unbalanced power sharing between stakeholders, which ultimately creates conflict. When referring to the perspective of the common pool resources (the CPR), the actors involved will all try to influence the division of powers. Ultimately, the stronger actor will play a more significant role in the partnership. Moreover, this approach recognizes that power sharing is the first step for successful co-management. This is unlike the management perspective that sets power sharing as a result of the co-management process in which the involved actors focus on solving each problem.

The current empirical study shows that the greatest problem for the KSNP area, either by residents who live around the four villages or those who come from outside the villages, is the demand for agricultural land (cultivated land) and the recognition of the rights of indigenous forest, which all lead to encroachment issues. Land disputes became frequent because the national park views the local population as the prime suspect of destruction and encroachment, yet fails to provide any realistic solutions. Although the intensity of land encroachment is different areas in all four villages, there is the same desire of the residents, so that throughout the four villages, people are willing to be relocated and were willing to leave farms that enter the protected area as long as an agreement in place among the actors. In the Pelompek village, people opt for outside-replacement land provided by the KSNP officials, which includes cultivating-farming inputs such as fertilizers, seeds and irrigation access. In the Sanggaran Agung Village, people who are caught encroaching on the KSNP land are willing to be relocated as long as they are given input assistance in the form of agriculture and training of agricultural and plantation commodities processing into finished products. Villagers in the Lempur Tengah Village prefer to be granted customary rights of forest management and local communities are not concerned about who among the state-two actors will be more dominant and take the initiative.

For the local government and the national park authority, local people's desire to be given assistance in the form of agricultural and livestock inputs and mentoring assistance for 
marketing is a difficult thing to do as a whole. Limited funding and human capabilities become an obstacle to the fulfillment of that desire. Therefore, the national park is often accused of not being aligned with the welfare needs of local communities. Meanwhile, local governments tend to be passive in meeting the desired objectives of local communities. Another issue is that in the past, these collaborations did not work out as desired; for example, the national park had provided assistance in the form of cinnamon trees to the local community, at the foot of Mount Kerinci, who encroached the region of KSNP to plant seedlings cinnamon exactly on the border of agricultural land with an area of KSNP though farmland itself included in the KSNP region. The purpose of this program was to prevent people from passing through the border, which was planted with cinnamon to benefit their land. In this case, the local government, military and police were involved in solving the dispute. Ultimately, the program failed because many of the tree seedlings were dead or missing and the action led to more widespread encroachment in the area.

When considering the above issues, it can be seen that each party would prefer to have more power than the others. Each party maintains its position as deserving to have access to the land, along with the power to acquire and to manage the land. However, it has been observed that members of the local communities were actually willing to be moved even it will be controlled the deal happens that lasted more continuous. In this case, the management approach, which emphasizes deliberation and democratic principles and is run according to the management perspective, may be appropriate. Co-management can be carried out for management of KSNP, however, the CPR approach is not appropriate for this case.

\subsubsection{Process}

In the past, the national park authority has lost the trust of the local communities, so that implemented programs focused more on bringing awareness to the negative effects of deforestation, along with the enforcement of legal regulations extensively throughout the forest area and particularly in the national park. For local governments, the cooperation between local communities and the national park manager is possible as long as there is a positive impact on welfare. As for the local communities themselves, the park's manager has ineffectively made efforts to support the local communities, yet these approaches did not have any impact on their basic needs, especially in terms of local livelihoods.

There are two key factors to consider: First, that members of the local community are willing to leave the land as long the KSNP authority compensate them with program that fit their wants and needs, it is regarded that aspect of the actual function wants more highlighted than the formal aspects. This means that each party can focus on solving their individual 
problems. Second, if the functional aspects are put forward, the management of the public perspective would be more appropriate in co-management arrangements with the condition as long as the local government supports the voice of the local community, though not directly at odds with the national park. Related to this condition, the national park has put forward more formal rules in an effort to resolve cases of violations.

\subsection{Obstacles related to developing co-management in Kerinci Seblat National Park according to stakeholders' perceptions}

The majority of Indonesia's conservation area, especially national parks, are currently facing serious problems. These problems often lead to conflicts which originate from damage to the conservation area, reduction of a land area, land acquisitions and land seizures from various actors who want to utilize the area. The majority of national parks are under pressure from local people both inside and outside of the parks (Mulyana, et al., 2010). Therefore, during the development of a national park, particular attention should be paid to the life patterns of people who have long been settled in the area before assigning this land to a national park (Alikodra, 2013).

The present investigation of Kerinci Seblat National Park (KSNP) has shown that there are two main obstacles to building collaborative management: repetitive law violations and persistent negative assessments of the KSNP authority; meanwhile, the park seems reluctant to build more intimate relationships with the local communities. With respect to law violations especially in the conservation area of KSNP, there are several factors at work such as the lack of awareness and information regarding laws and regulations. In these regions, common law violations are land encroachment, which attempts to expand a cultivation area within the conservation area, and the disappearance of stakes or separation between the KSNP areas with the community-owned forests. Negative perceptions of the KSNP manager were that activities organized by the KSNP authority did not meet the communities' problem root, as well as the KSNPs overall inability to cooperate with the local community and the local governments. The following sections will further explain the primary problems related to developing a co-management in the region.

\subsubsection{Repetitive law violations}

Repeated violations of the law is one of the biggest problems to build a program of effective co-management with a view to preserving conservation area. This law violations committed by the people from the local community, as well as people from outside the 
community; in both cases, the cultivation of land KSNP generally the biggest problem. Based on interviews with key informants, violations in protected areas is mainly caused by people who do not understand the rules and / or people who do not know how to preserve the ecosystem in KSNP. Requirement of land for cultivation and traditional perceptions of the local community that forest products are gifts from God is the reason to use a conservation area. In addition, many local residents have lived in the area of KSNP for a long period of time, and were there before the area was designated as a protected area, which is another reason when is conducted a discussion forum with the KNSP manager.

Encroachment on the conservation area often occurs in the northern part of Kerinci Regency, particularly in the Lindung Jaya village and Pelompek village. The land use for agriculture is high in the area because most people are categorized as farmers and are also in the productive age; therefore, few of them have left the Kerinci region to migrate to other areas or region. These individuals choose to continue their parents farming operations, especially after marriage, in order to meet the household needs. Consequently, local people frequently expand their cultivation area into the conservation area. On the other hand, the local people, especially younger generations in the southern part of Kerinci Regency such as Lempur Tengah Village and Sandaran Agung Village prefer to leave their villages to continue their education or work efforts in other provinces or abroad as migrant workers. They generally return to their village only after they feel established economically or are no longer able to work. However in this southern part of Kerinci Regency, law violations on the conservation area are still a relevant issues, specifically related to illegal logging and hunting of wildlife.

Another case of a barrier to develop collaborative management is a boundary stake where is originally placed between the local people's area and the KSNP area is moved or removed. Based on experience, the completion of the barrier case sometimes ends the conflict, which the local people was more defensive than the officers of KSNP. The barrier stakes are usually red and yellow stakes, where the yellow stakes serve as the border for the customary forests, where forests can be made into plantations with the permission of the person in charge of indigenous forests and, of course, permission from the manager of KSNP.

'Sometimes local people are more assertive than the officers of KSNP. For example, in a few months ago there was the local encroachers arrested by the officer, but the local people in large numbers turned hostile towards the officers. The situation can be controlled through bartering between the local people and the KSNP authority, without the involvement of the law, as it should be. The 
officer of KSNP did it in order to save the officer, to avoid bloody clashes and to avoid conflicts. Before the suspected people freely, the arrested people was suggested in order not to repeat his actions" (Respondent 13, Staff of The KSNP authority).

\subsubsection{Negative perceptions towards the KSNP authority}

The other problems in establishing co-management is the negative perceptions, especially those of the local community towards the authority of KSNP. In the perspectives of the local people, many of the introduced KSNP's programs do not meet the local people's needs and also the KSNP authority do not keep their agreements with the local people related to the KSNP programs to maintaining the conflict area so it is difficult to find a sufficient solution to change this perception because each actor is persistent in their arguments.

According to the key respondents of this study such as community leaders, traditional leaders and village officials, they just recognize the socialization activities of the authority like the program of awareness improvement on the conservation programs. The activities were dominated by presentations of the manager of KSNP's activities, which include the introduction of laws and regulations, as well as the identification of environmental detriments such as illegal logging. These activities tend to be less attractive to local communities because they do not benefit the community. The local people think only of survival in their daily life. In addition, the socialization did not conduct for all villages. For example, there are fifteen villages in one sub-regency, but the KSNP manager did socialization to villager about some conservation programs in only two villages. Consequently, there are many people who do not understand the rules and those who do are against the rules. The perception of local people is that the manager of KSNP should not blame the communities for violations because they do not feel that the KSNP manager has thoroughly explained the regulations and has failed to provide sufficient information.

The other perception is that the authority cannot keep its commitments. For example, the local people, especially farmers who want to build a road through the conservation area to more easily sell their agricultural commodities. Perishable agricultural commodities can be sold immediately to minimize deteriorated quality, however the authority is still very reluctant to open new roadways for fear that it will disturb the ecosystems in the KSNP area. Opening new roadways is an opportunity for local people (farmers) to market their agricultural products and to increase their income. The community holds the opinion that the authority of KSNP avoids meeting with local communities in an effort to avoid coming up with a solution that pleases both parties. 
"'For the KSNP manager, it should not be selfish. There are many programs without implementation and results. There are reasons related to the rules of research, economics, ecotourism and other classical rules. Local people did not really understand these rules" (Respondent 7, 50 years old, community leader in Кауи Aro).

Basically, local people really would like to cooperate with the authority of KSNP. However, the authority seems only to make promises which usually fall through. For example, KSNP had to establish a Nucleus Estate of Smallholders or Perkebunan Inti Rakyat $(P I R)$. The estate was cultivated by the core commodities of local people. For the initial step, the program was successful; however, the program was not sustainable in the following steps.

\subsection{Opportunities supporting collaborative action}

\subsubsection{Key success factors to build co-management in KSNP: Perspectives of stakeholders}

Co-management covers the sharing of rights and responsibilities among government agencies and the local community, with efforts being made on the basis of mutual agreement or negotiated agreement. This approach is required in the conservation area in order to minimize the potential for conflict and encourage co-management, factors that into similarities between stakeholders can be one solution previous experiences proved that the conventional strategy and the management of conflicts of interest of the state have often failed (Birner \& Mappatoba, 2002).

The needs of the local community can serve as a bridge for the implementation of comanagement with the local government and the KSNP authority. Although cases of land encroachment and illegal logging were found, the local communities who are also living in the area surrounding KSNP are aware of the prohibition regarding the use of lands in the protected area. This is especially true in the village of Lempur Tengah and surrounding local communities, which greatly appreciate the presence of customary law that prohibits them from damaging the surrounding forest. The perspective to conserve natural resources based on customary laws and norms can be used as a factor that supports developing a co-management. Sandström (2014) says that in relation to the development of an ongoing collaboration management effort, it is critical to identify who has access to and may use the resources in general. 
Basically, according to key respondents, the community within Kerinci Regency have their own way of preserving and conserving the ecosystems in KSNP, while the bad news is that immigrants may try to enter without understanding the environment and the importance of the well-respected territory. Some of the cultural activities organized on an annual basis in the two regions, Ketoresno in Kayu Aro and its surroundings, as well as Kenduri Sko in Lempur Tengah Village and surrounding communities of Lempur Tengah, provide evidence that the local community have great concern for the natural environment based on norms and traditional values. Such activities can be an entry point for the implementation of comanagement, especially in hopes of holding an event which may bring a sense of unity to all involved parties. Ketoresno and Kenduri Sko are the cultural events that combine traditional rituals into a ceremony which represents the benefits of harvest and serves as an expression of gratitude to God, the creator and giver.

Another factor that could affect the development of a co-management among the stakeholders in the Kerinci region is a program to care for the natural environment that has been initiated by the KSNP authority by targeting younger generations. The program also represents a form of empowerment to these youths; one of these programs is the Bakti Sakawana organization under the auspices of KSNP. The organization aims to train young men and women to be conservation keeper. Becoming a member of this organization is very easy; there are an unlimited number of openings and all candidates must simply go through the various phases, namely reception, orientation, conservation and inauguration. During training, the students are instructed by coaches from both the internal staffs of KSNP and the external trainers of KSNP with material that introduces the environment, aids in learning the meaning of the preservation of nature, agricultural elements and information about medicinal plants which is good considering the conditions of the integrity of the soil, and cultivation of agricultural or fisheries farm. This organization has been in operation for a long time; moreover, it provides an opportunity for the sons of the soil to get to know the area and begin having a role in protecting the forest. Moreover, the program gives way to future prospects that may become involved in the other KSNP programs later on. The another activity initiated by the KSNP authority, and relatively well-accepted by other stakeholders, is a partnership that involves NGOs and local communities through the program of the forest and land rehabilitation (Rehabilitasi Hutan dan Lahan/RHL) as part of the Forester Kerinci Seblat, which currently has 15 members. This program was developed to make improvements to the existing ecosystems in Gunung Tujuh sub-district, as well as to serve as a form of cooperation between the public and the KSNP authority in preserving nature. 


\subsubsection{Political and economic development to encourage a co-management}

The community and the KSNP manager need a joint solution for dealing with past problems that have not yet been solved. In this regard, it is important to have people who can respond quickly in the face of unresolved issues. This is also the duty of researchers or academics, namely to find the appropriate solution that can be extended upon all parties. However, there must also be support from the government and the KSNP manager to resolve the problem because people for this time tend to follow the government's decisions related to implementing the program which has not been regarded by the local people exactly.

A few years ago there was a plan of cooperation where the KSNP wanted to hold a small industry training camp for local communities, yet no follow-through occurred. This is another instance of awareness being raised for a program and not going any further, participants were already collected, the local government had already met to discuss the opportunity, they planned to empower local communities in the program with training models and other similar tactics, but the program was never implemented. And there used to be a discourse of their wish to provide compensation in order to maintain the quality of the environment or protected forests, but only just a discourse. A member of government or the manager of KSNP compensate forest protection by society given by the local government and also compensation please just managed by local governments, most of the compensation can be perceived and utilized by the community. For agricultural products in the western are wood, as much as $15 \%$ was sent to West Sumatra, the rest-many to Jambi, Palembang, Lampung, and Java. Supposedly from the KSNP authority includes programs that contribute in order to empower local communities.

\subsection{Solutions for conflicts related to protected natural resources management in the KSNP area}

In the Lempur Tengah village and surrounding communities, there is a desire to establish indigenous communities. The goal is to be given autonomous territory and forest management. Community-driven leaders of customary forest is theirs. Yani (2007) defines community customary law as regulating the ownership, control and utilization of forests to meet the various needs of community members. The utilization of indigenous forest by local communities are generally in the form of forest land used for agriculture, as a source of timber, fuel wood, traditional medicines, as well as a wild animal habitat. Yani (2007) further explains that the utilization of the indigenous forests will be governed by customary laws. 
Customary laws must be respected and complied with by the relevant customary law community. These laws have been known as the indigenous wisdom.

Local people who live surrounding the KSNP area are also demanding to be given the autonomous authority to manage these areas, by laws which they hoped would be strengthened with legally binding regulations. This means that attention and support is needed from both the local government and the national agency (the KSNP manager), as well as the facilities that the community tends to progress. The local communities should be involved in all matters related to policy making, so that they feel like they have a role in the process and they are taught to be aware of the importance of the environment. Because so far the government only forced manner without solutions or alternatives to the sustainability of local communities and promote KSNP, first it was suspected by the constraints on local government policy. Hence, there is a need for policies that lead to improvements in agriculture and deceive the public in the management of around KSNP.

\subsection{Similar need in the northern and southern regions to remove encroachers}

Involved parties must be invited to meet and talk together in order to find the best solution for all actors, namely the KSNP official, the Kerinci community and the local government. Furthermore, efforts should be made during these meetings to encourage the support of sustainable development and to proof a degree of coexistence among all parties. Basically, the community must be involved, be involved, so that they involve keep the KSNP area, so the collaboration of stakeholders give an effect to reach a common goal. The government has been urged to give attention to farmers whose land has penetrated the region. The desire of local communities, particularly for those who have been identified as encroachers, are given seedlings, fertilizers and cattle assistance if they are willing to leave the protected area. For example, community members in Kayu Aro, mainly farmers who farm at the foot of Mount Kerinci, expect attention and help from local governments and the KSNP manager to provide appropriate solutions such as farm aid. This could be overcome by the government and the park should take the initiative to conduct a survey or needs assessment to meet the requirements of local communities. Once these needs are recorded properly and the right of local communities then consulted back. For example, the community at the foot of Mount Kerinci are active in agricultural businesses and can be encouraged to leave the land as long as they are compensated. However, preferably this cattle breeding business should be conducted in groups in order to control. This revolving group business and also to avoid moral hazard farmers themselves. The success of cattle breeders in South Solok in West Sumatra province has been greatly inspired by the farmers and ranchers at the foothills of 
Mount Kerinci. However, several speakers from the KSNP authority said that cooperation with local people had ever done, but the results were disappointing. Community members were given a number of 200 ducks and advocation to be managed as a group, but it was failed because they were not open to the park. At the end of the survey, reports indicated that there were dead and a duck are organized into its own, if the program was successfull. The program would continue to the next program. It is not only to continue the program but also there would probably be larger cooperation between the park and local communities in which in this case, the program is form of a cow or goat rearing to enable people to not penetrated KSNP.

Another perception of local people is a desire to be involved within protection program for the KSNP area. People consider that the protected forest is not only to be managed by the manager, but also the forest should be owned by local people. Although there is no exclusive definition to describe co-management, there is a clear dichotomy between the state and local resource users (Carlsson and Berkes, 2004). It needs to be determined that collaborative management is a paradigm can be implemented to see the forest as a multipurpose. Aspect that has not worked is the utilization of forest environmental services such as travel services, water resources, water catchment (watershed), and other environmental services. Another potential utilization is a community-based forest management. For this time in this study area, the cooperation has only showed that the cooperation between the KSNP authority and local communities is only a socialization program of KSNP about the importance of local people conserve the forest. Supposedly, Governments of both local government or the KSNP authority should have special attention to the local people. Both Governments have full responsibility for the local community economy improvement of particular concern to farmers. On the another hand, the local People also must protect the forest from outsiders who want to take natural resources properly will damage the forest and local people should have a common purpose with the park to preserve nature and the ecosystem. In the future, there must be cooperation among local communities, the KSNP authority, local government, military, and police in crushing the person who is not responsible, if need be investigated to the brain from all the action that is detrimental to nature. Problems arise will in every situation, however, the establishment of a good cooperation will allow stakeholder to resolve the problem and to stop destroying activities within the forest by unresponsible people. It is very likely that an increase is in economic welfare could result from successfully Overcoming the problems related to encroachment. Finally, the ecotourism sector can be a driving sector for the economy, or serve to endorse activities or roomates improve welfare. 


\subsection{Considering ecotourism as the most potential factor in collaborations between stakeholders and KSNP management}

Basically, local communities, local government and the KSNP authority also need a joint solution in dealing with problems that have not been solved a long time, there must be those who can respond quickly in the face of the unresolved issues such as illegal logging, encroachment, and so forth. This also is the duty of the researchers or academics to find the appropriate solution to be given to all parties concerned. But there must also support from local government and the KSNP manager because people just follow how the flow of government that makes its way scenario of community life and the direction it goes. The local government and or the KSNP authority should compensate the communities' forest protection efforts. There are two supposed forest protection as a compensation of collaborative management from the local government. They are forest protection by society given by the local government and also compensation just managed by local governments. The most important of compensation is how to most of the compensation can be perceived and utilized by local communities. To date, several good programs and activities have been initiated and managed by the KSNP manager, local government and local communities that are related to ecotourism. Moreover, some of these programs have been organized on a large-scale organized and have been heavily centered on nature. These events indirectly promote the beauty and charm of the wealth of nature that lies within Kerinci Regency. Unfortunately, many of these programs are driven by only one stakeholder, when in reality, a collaboration would allow the programs from being just good, to being great. Some of the program and events are great candidates for the consideration of co-management efforts in terms of ecotourism.

The Festival of Lake Kerinci. The Festival of Lake Kerinci Seblat is an annual event that is held by the local government, in this case the Regional Tourist Office, in cooperation with local communities in Kerinci Regency and the KSNP authority. The Festival of Lake Kerinci Seblat is a good opportunity for introducing the culture, customs and natural resources of the region, or in this case to promote the Kerinci tourism attractions. This annual event has become a cultural highlight in the Kerinci communities, especially in 2014 was the first year festival of Lake Kerinci after it had been a vacuum for two years earlier that is 2012 and 2013. If the festival was not held three years in a row (in 2014), the permission of the national tourist ministry would be revocated to present the same festival in the future. The indigenous people were also very enthusiastic in welcoming the Festival of Lake Kerinci in 2014. Additionally, there is a Kerinci Bird Watching Club (KBWC), which is also under the 
KSNP authority, i.e., they move to Bird also cooperates with other institutions, but the existence of such organizations has not heard from again.

The focus group discussion of tourism consciousness. The tourism consciousness programm is the annual event of stakeholder meeting that is organized by the provincial tourist office. When this study was conducted, this event was presented by the provincial government. The committee invited some stakeholders such as local communities, youth local group concerned in organizing tourist events, local government, leader of coummnity, village chiefs, and the KSNP officials. In this event, local government and the KSNP representative presented the presentation talking about preservation and conservation protected area. Related tourism awareness program, all of stakeholder can preserve both flora and fauna. It should also be supported by regulation, but it is not quite to the regulation only. However, the regulation should be engaged with the customary low which is owned by local communities or indigenous communities. These laws can be implemented well if the laws are supported by all of stakeholder including the police to protect security.

Society is ready to assist the government in promoting tourism both domestically and overseas, therefore as long as those responsible and really realize every program that those have planned, it is not only used as a discourse to appease the public, it is not a solution, but also it even exacerbate the situation with the more her encroachment or illegal use of protected forest.

Managing parking areas at the entrance of the conservation area. Providing opportunities for communities to manage visitor parking lots around Lake Gunung Tujuh. Granting access to a local nature lovers group consisting of fifteen people on a regular basis fifteen days doing activities to clean up the way along the heading track to Lake Gunung Tujuh. Also the group of nature lovers who are predominately in an older age group is focused on replanting and rehabilitating of damaged plants along the pathway, particularly in conservation areas.

\subsection{The responsible-adaptive co-management as an appropriate strategy}

The community-based resources management (CBRM) strategy is recently known as a strategy which is still better in terms of natural resource management compared to the other strategies. This is partly because these strategies work in coordination with collective action choice when developing the design and the structure of the institution (Melissa Leach, 1999; Armitage, 2005). Moreover, there is no single definition of the CBRM. The CBRM is generally defined as a full community participation in resource management and decision- 
making to the technical level. Exogenous and endogenous variables are needed as an analysis technique to strengthen the CBRM strategy. This approach has been used across the country and is used in the management of wildlife, forests, fisheries, water resources, coastal area as well as national parks. It has been recorded in more than 50 countries and in 500,000 management organizations at the local level around the world have transferred authoritybased resource management and decision-making from the national level to the local level since 1990 (Armitage, 2005).

Over the course of time, the term of social forestry has changed to community forestry, and eventually joint forest management. Such management requires local control and it is indeed to provide powerful control over access to community forests. Unfortunately, many parties use this opportunity to use directly. The CBRM management in many implementations often does not meet expectations (Meinzen-Dick \& Knox, 1999). Then, the concept of natural resource management to shift the terms of Joint Forest Management (JFM), which is a program supported by the Ford Foundation and is also supported by the community and donors. It has attempted to distinguish between community forestry and forest management, based on the level of local control and collaboration. Over the last few decades, there has been a shift in the approach to natural resource management, going from a centralized to a community-based management system. Therefore, community involvement is always needed. Nevertheless, local communities are often blamed for the destruction of forests. At the same time, local people have lost control over much of the forests that have been managed by community members for generations (Fisher, 1995)

In order to it can differentiate between community forestry and JFM on the basis that any particular characteristics can be distinguished from the use of various projects, but there is a lot of overlap. Here, it becomes interesting because the involved parties to distinguish between community forestry and JFM based on the level of local control and collaboration.

Researchers prefer to use the term ',collaborative forest management" because this issue is related to a broader scope, before the term is exploring the different programs according to certain characteristics. Thus, the management of natural resources in Kerinci Regency is more aligned with responsible management. Natural resource managers should not stand alone, but each stakeholder is encouraged to cooperate. Overall, the CBRM seems less precise because the local people themselves still want government intervention in the sense that there is some level of cooperation between the public and the government. Here, the coorporation is instead of transferring responsibility from the state to local users or it shares responsibility for the management of natural resources, but the responsibility is in terms of the mindset of stakeholders to one another. For example, local people do not just think increased 
prosperity solely with their traditional livelihood, but they are also responsible for helping the government to maintain and preserve nature. How the way is, it does not damage the environment or penetrated and local communities are responsible for programs provided to them. Instead, the state is not only responsible for the preservation and protection of forests in order to ensure sustainability, but also the state government takes responsibility for the wellbeing of local communities. When referring to the wishes, the coorporation needs the people of each village, it can be conclude that this approach is in line with the area-based rural development (Giessen, 2009). With the area-based rural development perspective, management of conservation area can be an encounter with difficulties in the reality of different. Responsible adaptive co-management approach will also facilitate local communities build its social resilience. Keck \& Sakdapolrak (2013) has identified three dimensions related to social resilience; (1) Coping capacities to cope with and to overcome; (2) Adaptive capacities to learn from past experiences and to adjust their future challenges;

(3) Transformative capacities to foster individual welfare and sustainable societal robustness. 


\section{Chapter IX. Conclusion and Recommendation}

\subsection{Conclusion}

In writing this dissertation, the question arises as to how these experiences can be reproduced in the context of achieving the related research objectives it can give an offer against the idea or the model of the collaboration management in areas such as KSNP, where more than 50 percent of the area is designated as a conservation area.

The Kerinci society, especially villagers who live around the border of the park, are local people who have had the experience of collaborating with other parties involved in the management of KSNP. The ICDP program was introduced to these individuals in 2006, but it did not go smoothly because the program was intended to establish public awareness regarding the management of the conservation forest and was not in accordance with the original plan. The community viewed the program more as a way of granting help to community members so that they could economically improve their lives by bringing attention to the sustainability of the natural surroundings. Exogenous activities and initiatives did not blend with the characters, desires and needs of the local community.

Several patterns that have been developed by both the KSNP authority and the local governments seem to be less effective or have not achieved the expected results. For example, the program that led to the devolution, was not an efficient solution for solving cases related to illegal logging or forest encroachment in the KSNP area. The devolution, better known as the CBRM, is a strategy widely used for solving problems related to natural resource management; moreover, the natural resource management efforts have caused conflicts amongst users, ranging from the national to the local level. According to data from the KSNP management, the four villages that were selected for further evaluation in this research have had extensive issues with KSNP related to land encroachment and illegal logging, particularly in Gunung Tujuh and Kayo Aro villages which face high levels of land encroachment.

Several NGOs have tried to implement initiation and advocacy approaches to bridge the conflicts of interest between the local community and the KSNP authority. For instance, the LTA (Lembaga Tumbuh Alami) did not only make an information approach, but also gave options to farmers for planting coffee. Moreover, the farmers were also mentored starting from the introduction of seeds and including the processes of cultivating, harvesting, processing and marketing. Coffee farmers perceived this program as being very beneficial. Some of the respondents in the field study even suggested that this pattern of cooperation should be made between the local community and the local government, including the KSNP 
authority, in order to reduce the number of cases of land encroachment and conflicts of interest. In the academic world, this idea is known as 'collaborative management' and provides equal opportunities in terms of power and responsibility sharing to all involved stakeholders. The situation in Kerinci Regency could have been dealt with through a collaborative adaptive management approach. This approach provides equal opportunities in terms of power sharing, gives regulations that allow high levels of participation among stakeholders and provides a sustainable learning process for the stakeholders, which is important since decision-making is a continuous process. This is in accordance with the main principle of adaptive co-management: power sharing is the final process, not the starting point. How the shared actions among stakeholders are regulated depends on the approach that is developed during the process. It is important to determine if the management approach is based on discussion and consensus, or if it is based on common pool resources in which the state, through its agents, plays more roles in the management setting. In this regard, empirical studies in KSNP Regency, in particular the experience in the four villages within the regency of Kerinci, showed the distinction of the perspective between the local community and the KSNP authority. The investigation indicated that the local community desired having a discussion that would resolve problems among the users of the natural resources. The people in the four villages offered solutions that focused more on agricultural activities. Members of the three villages, Sanggaran Agung, Pelompek, and Lindung Jaya, wanted to solve the problem by emphasizing the importance of fulfilling the needs of the farmers. In order to expel the local people, as well as those deemed to be the forest encroachers who threaten the sustainability of KSNP, the KSNP party or the local government should provide aid or present the idea of shifting patterns and forms in the farm cultivations. All three of the villages had different ideas for how they could best interact with the other parties. Lindung Jaya village, as well as other villages at the foot of Mount Kerinci, wanted the KSNP authority and the local government to give them calves or cattle to encourage other methods of farming. This approach would allow farmers to switch to cattle production activities, there is no reason to utilize the conservation area land. This was intended in order to farmers who had moved to the breeder pattern would not return to use the conservation area lands. Meanwhile, those from the villages of Pelompek and Sanggaran Agung, especially those who actively used the conservation areas, preferred the solution of through the provision of seedlings, guidance and marketing. The community hoped that with the mentoring and involvement of the KSNP party, along with the government including seeds, grants, mentoring and marketing, that it would be able to minimize the forest encroachment because farmers would be more focused on productivity and the outcomes of marketing. Another case was the alternative solution 
given to the people of Lempur Tengah Village, where it was proposed that the village be an indigenous village. One of the consequences of this policy, however, is that the forest management will be controlled by local customs, while any uses and exploitations related to the land will be organized either alongside or completely by the KSNP authority. The role of traditional institutions influence the relation patterns of community to benefit the natural resources had also been examined by Koch, Faust, \& Barkmann (2008).

It is thus apparent that the solution proposed as a collective action to link the governance perspective dominantly performed by the local community with the CPR perspective dominantly performed by the KSNP authority is the proposition of an adaptive collaborative management. With this adaptive co-management, the power and responsibility sharing will be conducted through discussion and consensus with all stakeholders. Moreover, the participation rate of the community will be much greater than that of the KSNP authority when is the CPR approach is used. This process also becomes a sort of social learning endeavor for society as a whole because a collective action with regards to either agricultural activities or in the context of cultural concerns will last for a long time.

In the end, however, it must also be realized that the adaptive co-management approach emphasizes the wants and needs of each stakeholder. This means that each involved stakeholder or actor will only think of sustainability in the sense that they will only think about the outcomes which produce results for them. In other words, the adaptive comanagement approach leads to more sustainable actions and it gives opportunities to each stakeholder to maintain their position. In the case of KSNP, for example, the local community will act in a way that the cooperation is advantageous for them with respect to farm management and the overall level of well-being, while the KSNP authority may attempt to satisfy the wants and needs of the local community in the short term., although they are still trying to achieve their personal long term goals for the area. This goal is to expel the encroacher from the KSNP area. Later, the survival is the responsibility of each members of the community.

Here, the researcher captures one aspect of the management collaboration that can continuously bridge the interests of multi-stakeholders and binds them to each other infinitely, this aspect is referred to as the "perspective responsible adaptive co-management". Thus, the correct solution for collective action is by using this paradigm. This proposal is based not only on the collected data and the field observations, but also on the study of literature. Moreover, this approach does not merely look at the aspects of process, participation, power sharing and multiple stakeholders, but it also considers the responsibilities that must be taken by all involved stakeholders. For instance, when the KSNP authority has fulfilled the wants of the 
local community, the community does not only gradually leaving the encroachment area, but they also have developed an understanding of guarding the nature protection program and protecting the area's biodiversity. On the other hand, when the community has followed the wishes of the KSNP authority and leaves the encroachment areas, the KSNP party does not only work with the local government provide aid, or seeds or calves, but also increases economic prosperity in the local communities to provide long term solutions for economic marketing. The community gives an example performed by the LTA (Lembaga Tumbuh Alami) which is not only to provide coffee seedlings, but also the NGOs provides technical guidance for cultivation methods, and accompanies coffee farmers from the planting stage until the harvest stage and even provides solutions for marketing. If this kind of help is done by the KSNP authority in collaboration with the local government, the local community will then switch their farming system to be more compliant with the other parties' wishes.

If collaboration happens in this way, then the resource management strategies especially in KSNP, no longer need the CBRM approach because this co-management approach leads more to the devolution of power. Based on empirical studies, the local community does not want the responsibility and the power sharing to be given entirely to them. The local community does indeed want aid for their farming activities, but they also want the KSNP party and the local government to assist them in their farming activities. Based on the experience obtained through the implementation of this devolution, some abusive practices by certain parties or by the local community were often found; hence, the purpose of the protection of the conservation area is not accomplished. In addition to this negative experience, the area had already encountered failure with regards to co-management approaches through the unsuccessful introduction of the ICDP project. The adaptive comanagement approach is also believed to be less appropriate because at the end of the program, each party will maintain their original position and follow principles of sustainability: the sustainability of the program and the desire of each stakeholder. For example, when each party meets, the KSNP authority will encourage nature preservation and the protection of biodiversity. On the other hand, the community will maintain their original perception, i.e., continuing their standard farming activities and attempting to enhance wealth. In short to enrich the case studies of the KSNP area and perhaps to give solutions for the natural resource management for all stakeholders involved, the researcher once again proposes the concept of responsibility-adaptive co-management.

Adaptive co-management is still included as a potential approach because a collective action to compose new institutions for both rules and organization still requires processes, power sharing and participation. The principles are not enough, however, a principle which 
should be put in place is responsibility. Moreover, each stakeholder should have one vision, i.e., how the various parties can cooperate interdependently, to be dependent on one another in fulfilling what is wanted and needed by all parties and to ensure collective responsibility.

\subsection{Recommendations}

The focus of the recommendation from this study is related to the potential development of ecotourism. Ecotourism is important because even though the results of the empirical research studies did not find any indication that the local community was interested in the development of ecotourism, the researcher sees the potential of ecotourism as a hidden gem. This potential has not yet emerged, however, because the management efforts related to ecotourism have not been rapid enough, nor has a course of action been established. The researcher believes in the potential for ecotourism, and that it can also be one sector which can unify the vision of multiple stakeholders in the frame of the responsible-adaptive comanagement. The local government and the KSNP authority should be the two main parties involved in this co-management. To begin with, this sector cannot be charged to the community even though the initiative comes from them. The community of the Lempur Tengah village, for example, wanted their village to be an indigenous village. To realize this, responsibility cannot simply be handed over to the community; instead, the local government and the KSNP authority should play a primary role in the transition. Regarding the development and the management of ecotourism, the KSNP authority and the local government should be the primary drivers behind the movement, which ultimately invites the local community to initiate their collective action. Second, the current government under the rule of the new president has endeavored to make tourism a leading sector in the Indonesian economy. The new government's announced target is to increase the arrival of international tourists to 20 million people annually by the year 2019 (Pambagio, 2016). These plans are supported by the 16 Region National Tourism Strategy which KSNP including one of them, although the KSNP area is not included in the sixteen priorities such as Lake Toba (North Sumatra), Tanjung Lesung (Banten), Tanjung Kelayang (Bangka Belitung), Thousand Islands (DKI Jakarta), Borobudur (Central Java), Region Bromo-Tengger (Java Timut), Mandalika, Labuan Bajo (NTT), Wakatobi (Southeast Sulawesi) and Morotai (Maluku Utara). The researcher believes that the potential for ecotourism and tourism attractions within the Kerinci region will be one of the destinations of interest in the near future.

It is important to develop the ecotourism sector in the Kerinci valley, first because the government program that is launching the National Tourism Strategic Area will greatly impact the development of supporting infrastructure, such as airports, seaports, river and lake 
transportation, toll roads, etc. Thus, it is necessary readiness robust and reliable in terms of policy, the readiness of infrastructure and human resource development. The interesting thing will be the development of human resources that will inevitably come to include local communities or indigenous peoples. This means that if the responsible-adaptive comanagement approach discussed in this research were to be implemented between three or more of the stakeholders in relation to the development of ecotourism. It is not possible to develop the core destination areas in KSNP, yet some interesting eco-tourism attractions are still present in the utilization zones. In order to promote eco-tourism in KSNP, the types of regulation and organizational structures will be a crucial point in the negotiations within the framework of collaborative natural resource management. Furthermore, it is important for the KSNP authority to continue introducing preservation programs. Moreover, Indonesia has designated KSNP to be one of four Geoparks in Indonesia, which is referred to as the Merangin Geopark and is known to have many plant fossils within the region's rocks (Perdana, 2013). Indonesian Geoparks are included a network of global Geoparks, which are a region or geological heritage site that have ecological values and cultural heritage. These are frequently areas of conservation, education and sustainable development. Global Geoparks is a network of garden earth world shaped by UNESCO (United Nations Educational, Scientific and Cultural Organozation), which convened on two separate occasions to discuss the worldwide Geopark (Alamendah's, 2015). 


\section{References}

Abood, S. A., Lee, J. S., Burivalova, Z., Garcia-Ulloa, J., \& Koh, L. P. (2015). Relative Contributions of the Logging, Fiber, Oil Palm, and Mining Industries to Forest Loss in Indonesia. Conservation Letters 8(1), pp 58-67.

Adiprasetyo, T. (2010). Rancang Bangun Kebijakan Pengelolaan Taman Nasional Secara Berkelanjutan di Era Otonomi Daerah. Bogor: IPB.

Adiwibowo, S., Shobudddin, M., Savitri, L. A., Syaf, S., \& Yusuf, M. (2008). Analisis Isu Permukiman di Tiga Taman Nasional Indonesia. Bogor: SAINS-Sajogyo Institute.

Agnello, R. J., \& Donnelley, L. P. (1975). Property Rights and Efficiency in the Oyster Industry. The Journal of Law \& Economics, Vol. 18, No. 2 , pp 521-533.

Agrawal, A. (2003). Sustainable Governance of Common-Pool Resources: Context, Methods, and Politics. Annual Review of Anthropology, Vol. 32 , pp. 243-262.

Agung, I. (2001). Menguak Tabis Prasejarah di Alam Kerinci (Seri Sejarah Kerinci 1) (1 ed.). Jambi: Pemerintah Kabupaten Kerinci.

Agung, I. D., \& Idris, I. (2001). Menguak Tabir Prasejarah di Alam Kerinci. Sungai Penuh: Pemerintah Kabupaten Kerinci.

Akama, J. S., \& Kieti, D. M. (2003). Measuring tourist satisfaction with Kenya's wildlife safari: a case study of Tsavo West National Park. Tourism Management, 24, 73-81.

Alamendah's. (2015, September 26). alamendah.org. Retrieved from alamendah.org: https://alamendah.org/2015/09/26/gunung-sewu-jadi-geopark-dunia-kedua-diindonesia/

Alfonso Peter Castro, E. N. (2001). Indigenous People and Co-Management: Implications for Conflict Management. Environmental Science and Policy 4, 229-239.

Alikodra, H. S. (2013). Keanekaragaman Hayati bagi Ketahanan Bangsa Indonesia. In D. S. Suharjito, \& H. R. Putro, Pembangunan Kehutanan Indonesia Baru: Refleksi dan Inovasi Pemikiran (pp. 69-87). Bogor: IPB Press.

Allen, G. R. (2008). Conservation hotspots of biodiversity and endemism for Indo-Pacific coral reef fishes. Aquatic Conservation: Marine and Freshwater Ecosystem, 18, 541556.

Andrade, G. S., \& Rhodes, J. R. (2012). Protected Areas and Local Communities: an Inevitable Partnership toward Successful Conservation Strategies? Ecology and Society 17(4): 14.

Andy Crabtree, T. R. (2004). Collaborating around Collections: Informing the Continued Development of Photoware. Conference Paper. 
Appanah, S. (2016). Forest landscape restoration for Asia-Pacific forests. Bangkok: the Food and Agriculture Organization of the United Nations and RECOFTC - The Center for People and Forest.

Armitage, D. (2005). Adaptive Capacity and Community-Based Natural Resource Management. Environmental Management Vol. 35, No.6, pp 703-715.

Armitage, D. R., Plummer, R., Berkes, F., Arthur, R. I., Charles, A. T., Davidson-Hunt, I. J., . . . Wollenberg, E. K. (2009). Adaptive co-management for social-ecological complexity . Front Ecol Environ 7 (2), pp 95-102.

Arnold, J. M., \& Pe'rez, M. R. (2001). Can non-timber forest products match tropical forest conservation and development objectives? Ecological Economics 39, pp 437-447.

Aumeeruddy, Y. (1994). Local Representations and Management of Agroforests on the Periphery of Kerinci Seblat National Park, Sumatra, Indonesia. Montpelier - France: the United Nations Educational, Scientific and Cultural Organization .

Austin, K., Alisjahbana, A., Darusman, T., Boediono, R., Budianto, B. E., Purba, C., Stolle, F. (2014). Indonesia's Forest Moratorium: Impacts and Next. Washington, DC: World Resources Institute (Working Paper).

Auzel, P., \& Hardin, R. (2011). Colonial History, Concessionary Politics, and Collaborative Management of Equatorial African Rain Forests.

Babu, S. C., \& Reidhead, W. (2000). Monitoring natural resources for policy interventions:a conceptual framework, issues, and challenges. Land Use Policy 17, pp 1-11.

Badan Perencanaan Pembangunan Daerah Kabupaten Kerinci. (2009). Rancangan Peraturan Daerah tentang Rencana Pembangunan Jangka Menengah Daerah Kabupaten Kerinci tahun 2009-2014. Sungai Penuh: Bappeda, Kabupaten Kerinci.

Badan Perencanaan Pembangunan Daerah Kabupaten Kerinci. (2012). Rencana Tata Ruang Wilayah Kabupaten Kerinci tahun 2012-2032. Sungai Penuh: Bappeda Kabupaten Kerinci.

Badman, T., \& Bomhard, B. (2008). World Heritage and Protected Areas. Gland, Switzerland : IUCN (International Union for Conservation of Nature).

Bank, T. W. (2006). Sustaining Economic Growth, Rural Livelihoods, and Environmental Benefits: Strategic Options for Forest Assitance in Indonesia. Washington: World Bank.

Bank, T. W. (2006). Sustaining Economic Growth, Rural Livelihoods, and Environmental Benefits: Strategic Options for Forest Assistance in Indonesia. Washington D.C.: The World Bank.

Barkmann, J., Burkard, G., Faust, H., Fremerey, M., Koch, S., \& Lanini, A. (2010). Land tenure rights, village institutions, and rainforest conversion in Central Sulawesi (Indonesia). Environmental Science and Engineering, 141-160, pp 141-160. 
Barr, C., Barney, K., \& Laird, S. A. (2014). Governance Failures and the Fragmentation of Tropical Forests. In C. Kettle, \& L. Koh, Global Forest Fragmentation (pp. pp 132157). CAB International.

Barrow, C. (2006). Environmental Management for Sustainable Development (2nd Edition). New York: the Taylor \& Francis.

Baumol, W. J., \& Oates, W. E. (1988). The theory of environmental policy. Cambridge, the United States of America: the Press Syndicate of the University of Cambridge .

Becker, H. S., \& Gee, B. (1957). Participant Observation and Interviewing: A Comparison .

Bellwood, D. R., \& Meyer, C. P. (2009). Searching for heat in a marine biodiversity hotspot. Journal of Biogeography 36, 569-576.

Bennet, N. J., \& Dearden, P. (2014). Why local people do not support conservation: Community perceptions of marine protected area livelihood impacts, governance and management in Thailand. Marine Policy 44 , 107-116.

Berg, B. L. (2007). Qualitative Research Methods for the Social Sciemces. United States of America: California state University, Long Beach.

Berkes, F. (2007, September 25). Community-based conservation in a globalized world. PNAS, vol. 104, no. 39, pp. pp $15188-15193$.

Berkes, F. (2009). Evolution of Co-Management: Role of Knowledge Generation, Bridging Organization and Social Learning. Journal of Environmnetal Management, 90, 16921702.

Bernard, H. R., \& Gravlee, C. C. (2015). Handbook of Methods in Cultural Anthropology (Second Edition). London, the UK: Rowman \& Littlefield.

Beunen, R., Regnerus, H. D., \& Jaarsma, C. F. (2008). Gateways as a means of visitor management in national parks and protected areas. Tourism Management, 29, 138145.

Bickman, L., \& Rog, D. J. (1998). Handbook of Applied Social Research Methods. London, the UK: Sage Publications, Inc.

Birner, R., \& Mappatoba, M. (2002). Community Agreements on Conservation in Central Sulawesi: A Coase Solution to Externalities or a Case of Empowered Deliberative Democracy? STORMA Discussion Paper Series Sub-program A on Social and Economic Dynamics in Rain Forest Margins (pp. 1-31). Research Project on Stability of Rain Forest Margins (STORMA) .

Blouch, R. (2010). Zoning for People Within Indonesia's Kerinci Seblat National Park. Journal of Sustainable Forestry, 29, pp 432-450.

Blouch, R. (2010). Zoning for People Within Indonesia's Kerinci Seblat National Park. Journal of Sustainable Forestry, pp. 432-450. 
Borrini-Feyerabend, G., \& Hill, R. (2015). Governance for The Conservation of Nature. In G. L. Worboys, M. Lockwood, A. Kothari, S. Feary, \& I. Pulsford, Protected Area Governance (pp. pp 169-206). Canberra.

Borrini-Feyerabend, G., Kothari, A., \& Oviedo, G. (2004). Indig e nous and Local Communities and Protected Areas Towards Equity and Enhanced Conservation. Gland, Switzerland and Cambridge, UK: World Commission on Protected Areas (WCPA).

Borrini-Feyerabend, G., Pimbert, M., Farvar, M. T., Kothari, A., Renard, Y., Jaireth, H., . . . Warren, P. (2004). Sharing Power. Learning by doing in co-management of natural resources throughout the world. Teheran: IIED and IUCN/ CEESP/ CMWG.

Bouwen, R., \& Taillieu, T. (2004). Multi-party Collaboration as Social Learning for Interdependence: Developing Relational Knowing for Sistainable Natural Resource Management. Journal of Community \& Applied Social Psychology 14, pp 137-153.

Bratamihardja, M., Sunito, S., \& Kartasubrata, J. (2005). Forest Management in Java 19751999 Towards Collaborative Management. Bogor: ICRAF Southeast Asia Working Papaer.

Brax, J. (2002). Zoning the Oceans: Using the National Marine Sanctuaries Act and the Antiquities Act to Establish Marine Protection Areas and. Ecology Law Quarterly, Volume 29 , Issue 1 , 71-130.

Bromley, D. W. (2008). Formalising property relations in the developing world:The wrong prescription for the wrong malady. Land Use Policy 26, pp 20-27.

Brook, R. M. (2006). Factors Influencing Farmer's Concern Regarding Bovine Tubercolusis in Wildlife and Livestock around Riding Mountain National Park. Journal of Environmental Management 80, 156-166.

Brooks, T. M., Mittermeier, R. A., Fonseca, G. A., Gerlach, J., Hoffmann, M., Lamoreux, J. F., . . Rodrigues, A. S. (2006, JULY 7). Global Biodiversity Conservation Priorities. SCIENCE 313, 58, pp. 58-61.

Bruner, A. G., Gullison, R. E., Rice, R. E., \& Fonseca, G. A. (2001, JANUARY 5). Effectiveness of Parks in Protecting Tropical Biodiversity. SCIENCE, pp. 126-128.

Buckles, D. (1999). Conflict and collaboration in natural resource management. In D. Buckles, Conflict and collaboration in natural resource management (pp. 2-8). Washington, D.C.- USA: the International Development Research Centre (the World Bank).

Burkard, G. (2007). Community Conservation Agreements as Institutions for the Common Pool Resource Forest Margin: Genesis, Performance and Contexts in the Napu Valley . STORMA Discussion Paper Series Sub-program A on Social and Economic Dynamics in Rain Forest Margins (pp. 2-29). Goettingen-Germany: Research Project on Stability of Rain Forest Margins (STORMA) . 
Campbell, S. J., Kartawijaya, T., Yulianto, I., Prasetia, R., \& Clifton, J. (2013). Comanagement approaches and incentives improve management effectiveness in the Karimunjawa National Park, Indonesia. Marine Policy 41, pp 72-79.

Cantú-Salazar, L., \& Gaston, K. J. (2010, November 1). Very Large Protected Areas and Their Contribution to Terrestrial Biological Conservation. BioScience, Vol.60, No.10, pp. pp 808-818.

Carlson, K. C. (2012). Carbon Emissions from Forest Conversion by Kalimantan Oil Palm Plantation . Nature Climate Change, 283-287.

Carlsson, L., \& Berkes, F. (2005). Co-management: concepts and methodological implications. Journal of Environmental Management 75, 65-76.

Central Statistical Agency of Indonesia's Government. (2016, April 10). www.bps.go.id. Retrieved from www.bps.go.i.

Cernea, M. M., \& Schmidt-Soltau, K. (2006). Poverty Risks and National Parks: Policy Issues in Conservation and Resettlement. World Development, Volume 34, Issue 10, pp $1808-1830$.

Chape, S., Harrison, J., Spalding, M., \& Lysenko, I. (2005). Measuring the extent and effectiveness of protected areas as an indicator for meeting global biodiversity targets. Philosophical Transactions of The Royal Socitey B, 443-455.

Chape, S., Harrison, J., Splading, M., \& Lysenko, I. (2005). Measuring the Extent and Effectiveness of Protected Areas as An Indicator for Meeting Global Biodiversity Targets. Philosopical Transactions of The Royal Society, pp 443-455.

Chomitz, K. M. (2006). At Loggerheads? Agricultural Expansion, Poverty Reduction, and Environment in The Tropical Forest. Washington DC: The World Bank.

Chowdhury, M. S., \& Koike, M. (2010). An overview on the protected area system for forest conservation in Bangladesh. Journal of Forestry Research, 111-118.

Clifton, J. (2003). Prospects for co-management in Indonesia's marine protected areas. Marine Policy 27, 389-395.

Clifton, J., \& Benson, A. (2006). Planning for Sustainable Ecotourism: The Case for Research Ecotourism in Developing Country Destinations. Journal of Sustainable Tourism, pp 236-254.

Coase, R. H. (1937). The Nature of the Firm. Economica, New Series, Vol. 4, No. 16, pp 386405.

Colfer, C. J., \& Capistrano, D. (2005). The Politics of Decentralization Forests, People and Power. the UK and USA: Center for International Forestry Research (CIFOR).

Conley, A., \& Moote, M.A. (2010). Evaluating Collaborative Natural Resource Management. Society \& Natural Resources: An . 
Coria, J., \& Calfucura, E. (2012). Ecotourism and the development of indigenous communities: The good, the bad, and the ugly. Ecological Economics 73 , pp 47-55.

Cundill, G., \& Fabricius, C. (2009). Monitoring in adaptive co-management: Toward a learning based approach. Journal of Environmental Management 90, pp 3205-3211.

Dauvergne, P. (1993-1994). The Politics of Deforestation in Indonesia. Pacific Affairs, Vol. 66, No. 4, 497-518.

DeFries, R., Hansen, A., Turner, B. L., Reid, R., \& Liu, J. (2007). Land Use Change around Protected Areas: Management to Balance Human Needs and Ecological Function. Ecological Applications, 17(4), pp. 1031-1038.

Defries, R., Hansen, A., Turner, B. L., Reid, R., \& Liu, J. (2007). Land Use Change around Protected Areas: Management to Balance Human Needs and Ecological Function. Ecological Applications, Vol. 17, No. 4, pp 1031-1038.

Deguignet, M., Juffe-Bignoli, D., Harrison, J., MacSharry, B., Burgess, N., \& Kingston, N. (2014). United Nations List of Protected Areas. Cambridge, The UK: United Nations Environment Programme-World Conservation Monitoring Centre .

Dietz, T., Ostrom, E., \& Stern, P. C. (2003, December 12). The Struggle to Govern the Commons. SCIENCE, Vol 302, pp. pp 1907-1912.

Dinas Kehutanan dan Perkebunan Kabupaten Kerinci. (2011). Statistik Kehutanan dan Perkebunan Kabupaten Kerinci 2011. Sungai Penuh: Dinas Kehutanan dan Perkebunan.

Dudley, N. (2008). Guidelines for Applying Protected Area Management Categories. Gland, Switzerland: IUCN (International Union for Conservation of Nature).

Dudley, N. (2013). Guidlines for Applying Protected Area Management Categories. Gland, Switzerland: IUCN.

Eagles, P. F., McCool, S. F., \& Haynes, C. D. (2002). Sustainable Tourism in Protected Areas Guidelines for Planning and Management. Gland, Switzerland and Cambridge, UK: IUCN.

Eilenberg, M. (2015). Shades of green and REDD: Local and global contestations over the value of forest versus plantation development on the Indonesian forest frontier. Asia Pacific Viewpoint, Vol. 56, No. 1, 48-61.

Elo, S., \& Kynga“s, H. (2007). The qualitative content analysis process. Journal of Advanced Nursing 62(1), pp 107-115.

Engel, S., Pagiola, S., \& Wunder, S. (2008). Designing payments for environmental services in theory and practice: An overview of the issues. Ecological Economics 65, pp $663-$ 674.

Engel, S., Palmer, C., \& Pfaff, A. (2013). On the Endogeneity of Resource Comanagement: Theory and Evidence from Indonesia. Land Economics, 89 (2), pp 308-329. 
Etzold, B., Jülich, S., Keck, M., Sakdapolrak, P., Schmitt, T., \& Zimmer, A. (2012). Doing Institutions: A Dialectic Reading of Institutions and Social Practices and Its Relevance for Development Geography. Erdkunde Vol.66, No.3, pp 185-195.

Ezebilo, E. E., \& Mattsson, L. (2010). Socio-economic benefits of protected areas as perceived by local people around Cross River National Park, Nigeria. Forest Policy and Economics 12, 189-193.

Faust, H., Maertens, M., Weber, R., Nuryartono, N., Rheenen, T. v., \& Birner, R. (2003). Does Migration lead to Destabilization of Forest Margins? - Evidence from an interdisciplinary field study in Central Sulawesi . STORMA Discussion Paper Series Sub-program A on Social and Economic Dynamics in Rain Forest Margins . Goettingen: Research Project on Stability of Rain Forest Margins (STORMA) .

Faust, H., Maertens, M., Weber, R., Nuryartono, N., Rheenen, T. v., \& Birner, R. (2003). Does Migration lead to Destabilization of Forest Margins? Evidence from an interdisciplinary field study in Central Sulawesi. STORMA Discussion Paper Series.

Fennell, D. A. (2003). Ecotourism: an introduction (2nd Edition). London: the Taylor \& Francis.

Ferraro, P. J., \& Kiss, A. (2002, November 29). Direct Payments to Conserve Biodiversity. SCIENCE, Vol 298, pp. 1718-1719.

Feyerabend, G. B. (1996). Collaborative Management of Protected Areas: Tailoring The Approach To The Context. Gland, Witzerland: IUCN.

Fisher, R. (1995). Collaborative Management of Forest for Conservation and Development. IUCN-The World Conservation Union.

Forestry and Plantation Office of Kerinci Regency. (2010). Data Luar Hutan dan Perkebunan Kabupaten Kerinci. Sungai Penuh: Dinas Perkebunan dan Kehutanan.

Fortin, M.-J., \& Gagnon, C. (1999). An Assesment of Social Impacts of National Parks on Communities in Quebec, Canada. Environmental Conservation 26, 200-211.

Frankistoro, F. (2006). Potensi Keanekaragaman Jenis Tumbuhan di Taman Nasional Kerinci Seblat (Studi Kasus di Resort Gunung Tujuh dan Kecamatan Kayu Aro, Kabupaten Kerinci, Jambi). Tesis. Bogor: Fakultas Kehutanan, Institut Pertanian Bogor.

Fritzherbert, E. S. (2008). How Will Oil Palm Expansion Affect Biodiversity? Trends in Ecology and Evolution, 538-545.

FuÈhrer, E. (2000). Forest functions, ecosystem stability and management. Forest Ecology and Management 132, pp 29-38.

Fung, A. (2006). Varieties of Participation in Complex Governance. Public Administration Review, Vol. 66, Special Issue: Collaborative Public Management, pp 66-75.

Fung, A., \& Wright, E. O. (2001). Deepening Democracy: Innovation in Empowered Participatory Governance. Politics \& Society, Vol. 29, No. 1, pp 5-41. 
G.R., v. d. (2010). Global Fire Emissions and the Contribution of Deforestation, Savana, Forest, Agricultural, and Peat Fire (1997-2009). Atmospheric Chemistry and Physic 10, 11707-11735.

Garrick, D., Whitten, S. M., \& Coggan, A. (2013). Understanding the evolution and performance of water markets and allocation policy: A transaction costs analysis framework. Ecological Economics 88, pp 195-205.

Gaston, K. J., Jackson, S. F., Cantú-Salazar, L., \& CruzPiñón, G. (2008). The Ecological Performance of Protected Areas. Annual Review of Ecology, Evolution, and Systematics, Vol. 39 , 93-113.

Gatto, M., Wollni, M., \& Qaim, M. (2015). Oil palm boom and land-use dynamics in Indonesia: The role of policies and socioeconomic factors. Land Use Policy 46, pp 292-303.

Gaventa, J. (2002). Towards Participatory Local Governance: Six Propositions for Discussion. In I. Christoplos, B. Ogle, R. Persson, L. Prage, \& J. Toborn, Participation - Where is It Heading? (pp 29-35). UPPSALA, Sweden: the Swedish University of Agricultural.

Gehring, K. (2013). Who Benefits from Economic Freedom? Unraveling the Effect of Economic Freedom on Subjective Well-Being. World Development Vol. 50, pp 74-90.

Geographic, National. (2011, Juli). Jejak Langkah Taman Nasional di Nusantara. Jakarta: National Geographic.

Getzner, M., Jungmeier, M., \& Pfleger, B. (2012). Evaluating Management Effectiveness of National Parks as a Contribution to Good Governance and Social Learning. Klagenfurt: InTech.

Giessen, L. (2009). Regional governance in rural development programmes - which role for forestry? Folia Forestalia Polonica, series A, 2009, Vol. 51(1), pp 54-60.

Giessen, L. (2011). Reviewing empirical explanations of policy change: Options for its analysis and future fields of research. Allgemeine Forst-und Jagdzeitung, pp 248-259.

Giessen, L., Kleinschmit, D., \& Böcher, M. (2009). Between power and legitimacy Discourse and expertise in forest and environmental governance. Forest Policy and Economics 11, pp 452-453.

Gillison, A., \& Liswanti, N. (2004). Assessing biodiversity at landscape level in northern Thailand and Sumatra (Indonesia): the importance of environmental context. Agriculture, Ecosystems and Environment, 104, 75-86.

Gossling, S. (2002). Human-Environmental Relations with Tourism. Annals of Tourism Research, Vol. 29, No. 2, pp 539-556.

Government of Kerinci Regency. (2009). Rencana Program Investasi Jangka Menengah (RPIJM) Kabupaten Kerinci. Sungai Penuh: Pemerintah Daerah Kabupaten Kerinci. 
Government of Kerinci Regency. (2012). Rencana Tata Ruang Wilayah Kabupaten Kerinci tahun 2012-2032. Sungai Penuh: Badan Perencanaan Pembangunan Daerah (Bappeda).

Gregersen, H., Contreras-Hermosilla, A., White, A., \& Phillips, L. ( 2004). Forest Governance in Federal Systems: An Overview of Experiences and Implications for Decentralization. Jakarta: SMK Grafika Desa Putra, Indonesia.

Gross-Camp, N. M. (2012). Payments for Ecosystem Services in An African Protected Area: Exploring Issues of Legitimacy, Fairness, Equity and Effectiveness. Cambridge Journals, 24-33.

Grover, V. I., \& Krantzberg, G. (2013). Co-Management: Principles and Complexities. In V. I. Grover, \& G. Krantzberg, Water Co-Management (pp. pp 1-15). Hamilton, Canada: CRC Press.

Gurney, G. G., Cinner, J., Ban, N., Pressey, R. L., Pollnac, R., Campbell, S. J., Setiwan, F. (2014). Poverty and protected areas: An evaluation of a marine integrated conservation and development project in Indonesia. Global Environmental Change, vol. 26, pp. 98-107.

Gurung, D. B., \& Seeland, K. (2008). Ecotourism in Bhutan Extending its Benefits to Rural Communities. Annals of Tourism Research, Vol. 35, No. 2, pp 489-508.

Haba, J. (2013). Bukit Tigapuluh: Persepsi Stakeholder dan Masyarakat Melayu. In H. Hidayat, J. Haba, R. Siburian, \& H. Hidayat, Politik Ekologi Pengelolaan Taman Nasional Era Otda (pp. pp 11-40). Jakarta: LIPI Press \& Yayasan Pustaka Obor Indonesia.

Hall, P. A., \& Taylor, R. C. (1996). Political Science and the Three New Institutionalisms. MPIFG Scientific Advisory Board, as a public lecture during the Board's meeting (pp. pp 1-32). Köln, Germany: Max-Planck-Institut für Gesellschaftsforschung.

Hayes, T. M. (2006). Parks, People, and Forest Protection:An Institutional Assessment of the Effectiveness of Protected Areas. World Development, Vol. 34, No. 12, 2064-2075.

Hein, J., Adiwibowo, S., Dittrich, C., Rosyani, Soetarto, E., \& Faust, H. (2015). Rescaling of Access and Property Relations in a Frontier Landscape: Insights from Jambi, Indonesia. The Professional Geographer, pp 1-10.

Hendratmoko, Y., \& Pratiwi, D. I. (2013). Aplikasi Investasi Pariwisata Alam Taman Nasional Kerinci Seblat. Sungai Penuh: Balai Besar TNKS, Sub Bagian Perencanaan dan Kerjsama.

Hermanns, T., Helming, K., Schmidt, K., König, H. J., \& Faust, H. (2015). Stakeholder Strategies for Sustainability Impact Assessment of Land Use Scenarios: Analytical Framework and Identifying Land Use Claims . Land 4, pp 778-806. 
Hidayat, H. (2013). Kerinci Seblat: Dalam Diskursus Otonomi Daerah. In H. Hidayat, J. Haba, \& R. Siburian, Politik Ekologi Pengelolaan Taman Nasional Era Otda (pp. pp 42-75). Jakarta: LIPI Press \& Yayasan Pustaka Obor Indonesia.

Hidayat, H., Haba, J., \& Siburian, R. (2011). Politik Ekologi Pengelolaan Taman Nasional Era Otda. Jakarta: LIPI Press \& Yayasan Pustaka Obor Indonesia.

Hillman, A. K. (2001). Shareholder Value, Stakeholder Management, And Social Issues: What's The Bottom Line? Strategic Management Journal, 22, 125-139.

Holton, J. A. (1995). Building Trust and Collaboration in A Virtual team. Team Performance Management: An International Journal, 36-47.

Howard S. Becker, B. G. (1957). Participant Observation and Interviewing: Comparison. sfaajournals.net, pp. 28-32.

Hsieh, H.-F., \& Shannon, S. E. (2005). Three Approach to Qualitative Content Analysis. Qualitative Health Research, Vol.15, No. 9, pp 1277-1288.

http://jambiprov.go.id/index.php?letluaswil/unduh. (2015, December 30). Retrieved from http://jambiprov.go.id/index.php?letluaswil/unduh

Hughes, R. F. (2001). Integrating Conservation and Development Experience: A Review and Bibliography of The ICDP Literature. London: International Institute for Environmental and Development, Simmons Printers, Chelmsford.

Hughes, R., \& Flintan, F. ( 2001). Integrating Conservation and Development Experience: A Review and Bibliography of The ICDP Literature. London, United Kingdom: International Institute for Environment and Development.

Hvenegaard, G. T., \& Dearden, P. (1998). Ecotourism Versus Tourism in A Thai National Park. Annals of Tourism Research, Vol. 25, No. 3, 700-720.

Imperial, M. (1999). Institutional Analysis and Ecosystem-Based Management: the Institutional Analysis and Development Framework. Environmental Management, 449-465.

Indarto, J., Kaneko, S., \& Kawata, K. (2015). Do Forest Permits Cause Deforestation in Indonesia? International Forestry Review, 17(2), pp 165-181.

Indonesia, R. o. (1990, March 18). Undang-Undang Republik Indonesia Nomor 5 tahun 1990 tentang Konservasi Sumber Daya Alam Hayati dan Ekosistemnya. Retrieved from http://www.hukumonline.com/: http://www.hukumonline.com/pusatdata/download/lt4c3d7bbdb37aa/node/371

Indonesian Goverment. (Nomor 28 tahun 2011). Pengelolaan Kawasan Suaka Alam dan Kawasan Pelestarian Alam. Indonesia.

Indonesia's Ministry of Tourist. (2016, April 10). http://www.kemenpar.go.id/. Retrieved from http://www.kemenpar.go.id/: http://www.kemenpar.go.id/asp/index.asp 
Indrawan, M., Lowe, C., Sundjaya, Hutabarat, C., \& Black, A. (2013). Co-management and the creation of national parks in Indonesia: positive lessons learned from the Togean Islands National Park. Journal of Environmental Planning and Management, Vol. 57, No. 8, 1183-1199.

Irawan, S., Tacconi, L., \& Ring, I. (2013). Stakeholders' incentives for land-use change and REDD+: The case of Indonesia. Ecological Economics 87, pp 75-83.

IUCN. (1996). World Conservation Congress; Resolution and Recommendation. Montreal, Canada: IUCN.

IUCN. (2008). World Heritage and Protected Areas. In T. Badman, \& B. Bomhard, World Heritage and Protected Areas (p. p 2). Gland, Switzerland: IUCN (International Union for Conservation of Nature).

IUN. (2007). Defining Protected Areas. Gland, Switzerland : IUCN.

John R. Parkins, R. E. (2005). Public Participation as Public Debate: A Deleberative Turn in Natural Resource Management. Society and Natural Resources, 18, 529-540.

Johnson, R. B., \& Onwuegbuzie, A. J. (2004). Mixed Methods Research: A Research Paradigm Whose Time Has Come. Educational Researcher, Vol. 33, No. 7, pp 14-26.

Johnson, R. B., Onwuegbuzie, A. J., \& Turner, L. A. (2007). Toward a Definition of Mixed Methods Research. Journal of Mixed Methods Research Volume 1 Number 2, pp 112133.

Juutinen, A., Mitani, Y., Mäntyamaa, E., Shoji, Y., Siikamäki, P., \& Svento, R. (2011). Combining ecological and recreational aspects in national park management:A choice experiment application. Ecological Economics, Vol. 70, Issue 6, 1231-1239.

K.Obidzinski, \& M.Chaudhury. (2009). Transition to timber plantation based forestry in Indonesia: towards a feasible new policy. International Forestry Review, 11(1), pp 7987.

Karki, S. T. (2013). Do protected areas and conservation incentives contribute to sustainable livelihoods? A case study of Bardia National Park, Nepal. Journal of Environmental Management 128, 988-999.

Karyoedi, M. (2006). Eksternalitas dan Transaction Costs dalam Mekanisme Pasar pada, Pengembangan Lahan dan Properti di Kawasan Perkotaan-Bandung. Jurnal Perencanaan Wilayah dan Kota, Vol.17/No.2, pp 1-20.

Kasih, N. (2012). Konsep Pemberdayaan Masyarakat Kawasan Taman Nasional Kerinci Seblat (TNKS), Wilayah Kabupaten Musi Rawas Provinsi Sumatera Selatan. Bogor: Sekolah Pascasarjana, Institut Pertanian Bogor.

Keck, M., \& Sakdapolrak, P. (2013). What is Social Resilence? Lesson Learned and Ways Forward? Erdkunde Vol.67 No.1, pp 5-19. 
Keen, M., Brown , V. A., \& Dyball, R. (2005). Social Learning in Environmental Management Towards a Sustainable Future. the UK and USA: Earthscan.

Khalik, I. (2007). Analisis Kelembagaan Pengelolaan Daerah Penyangga Taman Nasional Kerinci Seblat: Studi Kasus di Eks HPH PT Maju Jaya Raya Timber Kabupaten Bengkulu Utara, Provinsi Bengkulu . Bogor: Sekolah Pascasarjana, Institut Pertanian Bogor.

Khan, T. (2014). Kalimantan's biodiversity:developing accounting models to prevent its economic destruction. Accounting, Auditing \& Accountability Journal, Vol. 27 Iss 1, pp. $150-182$.

Kitzinger, J. (1995). Introducing Focus Groups. BMJ, Glasgow University Media Group, 299302.

Klain, S. C., Beveridg, R., \& Bennett, N. J. (2014). Ecologically sustainable but unjust? Negotiating equity and authority in common-pool marine resource management. Ecology and Society 19(4): 52.

Koch, S., Faust, H., \& Barkmann, J. (2008). Diff erences in Power Structures Regarding Access to Natural Resources at the Village Level in Central Sulawesi (Indonesia). Austrian Journal of South-EastAsean Vol 1, No 2, pp 59-81.

Krott, M., Bader, A., Schusser, C., Devkota, R., Maryudi, A., Giessen, L., \& Aurenhammer, H. (2014). Actor-centred power: The driving force in decentralised community based forest governance. Forest Policy and Economics 49, 34-42.

L.Strauss, A., \& Corbin, J. M. (1998). Basics of Qualitative Research : Techniques and Procedures for Developing Grounded Theory. Thousand Oaks, California ; London, United Kingdom; New Delhi, India: Sage Publications, Inc.

Lambin, E. F., \& Meyfroidt, P. (2011, March 1). Global land use change, economic globalization, and the looming land scarcity. PNAS no.09, pp. pp 3465-3472.

Lambin, E., Meyfroidt, P., Rueda, X., Blackman, A., Borner, J., Cerutti, P., . . . Wunder, S. (2014). Effectiveness and synergies of policy instruments for land use governance in tropical regions. Global Environmental Change, Volume 28, pp 129-140.

Lambini, C. K., \& Nguyen, T. T. (2014). A comparative analysis of the effects of institutional property rights on forest livelihoods and forest conditions: Evidence from Ghana and Vietnam. Forest Policy and Economics Volume 38, pp 178-190.

Lars Carlsson, F. B. (2005). Co-management Concepts and Methodological Implications. Journal of Environmental Management 75, 65-76.

Laurance, W. F., Sayer, J., \& Cassman, K. G. (2014, February 1). Agricultural expansion and its impacts on tropical nature. Trends in Ecology \& Evolution, Vol. 29, No. 2, pp. pp 107-116. 
Lee, J. S., Abood, S., Ghazoul, J., Barus, B., Obidzinski, K., \& Koh, L. P. (2014). Environmental Impacts of Large-Scale Oil Palm Enterprises Exceed that of Smallholdings in Indonesia. Conservation Letters 7(1), pp 25-33.

Lemos, M. C., \& Agrawal, A. (2006). Environmental Governance. Annu. Rev. Environ. Resour., 31, 297-325.

Leonard, B., \& Rog, D. J. (1998). Handbook of Applied Social Research Methods. (D. J. Leonard Bickman, Ed.) London: SAGE Publications, Inc.

Leslie, D. (2015). Tourism enterprise : developments, management and sustainability . London, UK: CAB International.

Leverington, F., Costa, K. L., Pavese, H., Lisle, A., \& Hockings, M. (2010). A Global Analysis of Protected Area Management Effectiveness. Environmental Management.

Linkie, M. M. (2010). Habitat Destruction and Poaching Threaten the Sumatran Tiger in Kerinci Seblat National Park, Sumatra. International Forestry Review, Vol. 12, No. 4 , 349-360.

Linkie, M., Dinata, Y., Nofrianto, A., \& Leader-Williams, N. (2007). Patterns and perceptions of wildlife crop raiding in and around Kerinci Seblat National Park, Sumatra. Animal Conservation 10, 127-135.

Linkie, M., Dinata, Y., Nofrianto, A., \& Leader-Williams, N. (2007). Patterns and perceptions of wildlife crop raiding in and around Kerinci Seblat National Park, Sumatra. Animal Conservation 10, pp 127-135.

Linkie, M., Smith, R. J., Zhu, Y., \& Leader-Williams, N. (2007). Evaluating Biodiversity Conservation around a Large Sumatran Protected Area. Conservation Biology, Volume 22, No. 3, pp 683-690.

Linkie, M., Smith, R. J., Zhu, Y., Martyr, D. J., Suedmeyer, B., Pramono, J., \& LeaderWilliams, N. (2008). Evaluating Biodiversity Conservation around a Large Sumatran Protected Area. Conservation Biology, Vol. 22, No. 3, 683-690.

Liu, J., Qu, H., Huang, D., Chen, G., Yue, X., Zhao, X., \& Liang, Z. (2014). The role of social capital in encouraging residents' pro-environmental behaviors in community-based ecotourism. Tourism Management 41, pp 190e201.

Mahanty, S., Stacey, N., Holland, P., Wright, A., \& Menzies, S. (2007). Learning to learn: Designing monitoring plans in the Pacific Islands International Waters Project. Ocean \& Coastal Management 50, pp 392-410.

Mancur Olson, J. ( 1995 ). The Devolution of the Nordic and Teutonic Economies. The American Economic Review, Vol. 85, No. 2, pp 22-27.

Mancur Olson, J. (1996). Distinguished Lecture on Economics in Government: Big Bills Left on the Sidewalk: Why Some Nations are Rich, and Others Poor. The Journal of Economic Perspectives, Vol. 10, No. 2, pp. 3-24. 
Manor, J. (1999). The political economy of democratic decentralization /. Washington, United State: The International Bank for Reconstruction and Development/ The World Bank.

Manullang, S. (1999). Kesepakatan Konservasi Masyarakat dalam Pengelolaan Kawasan Konservasi. Jakarta: Environmental Policy and Institutional Stregthening IQC .

Manurun, R. (2002). Ecotourism in Indonesia. In T. Hundloe, Linking Green Productivity to Ecotourism; Experiences in The Asia-Pasipic Region (pp. 98-101). Brisbane: University of Queensland Printery.

Mappatoba, M. (2004). C-Management of Protected area; The case of Community Agreements on Conservation in the Lore Lindu National Park, Central Sulawesi Indonesia. Göttingen: Cuvillier Verlag.

Margono, B. A., Potapov, P. V., Turubanova, S., Stolle, F., \& Hansen, M. C. (2014, August). Primary forest cover loss in Indonesia over 2000-2012. Nature Climate Change, pp. pp 730-735.

Marion Mehring, C. S.-E. (2011). Local Institutions: Regulation and Valuation of Forest UseEvidence from Central Sulawesi, Indonesia. Land Use Policy 28, 736-747.

Maryam Alavi, D. E. (2001). Knowledge Management and Knowledge Management system: Conceptual Foundations and Research Issues. MIS Quartely, 107-136.

Matthew B. Miles, A. M. (1994). Qualitative Data Analysis: An Expanded Sourcebook. the United States of America: Sage Publications, Inc.

McCann, L., \& Easter, K. W. (2004). A framework for estimating the transaction costs of alternative mechanisms for water exchange and allocation. Water Resources Research, VOL. 40, pp 1-6.

McNeely, J. A. (1994). Lesson From The Past: Forest And Biodiversity. Biodiversity and Conservation.

Meadowcroft, J. (2004). Participation and sustainable development: modes of citizen, community and organisational involvement. In W. M. Lafferty, Governance for Sustainable Development; The Challenge of Adapting Form to Function (pp. pp 162190). Cheltenhan, UK \& Northampton, MA, USA: Edward Elgar Publishing Limited.

Medail, F., \& Quezel, P. (1999). Biodiversity Hotspots in the Mediterranean Basin: Setting Global Conservation Priorities. Conservation Biology, Volume 13, No. 6, 1510-1513.

Mehring, M., Seeberg-Elverfeldt, C., Koch, S., Barkmann, J., Schwarze, S., \& StollKleemann, S. (2011). Local institutions: Regulation and valuation of forest useEvidence from Central Sulawesi, Indonesia. Land Use Policy 28, 736-747.

Melissa Leach, R. M. (1999). Environmental Entitlements: Dynamics and Institution in Community-Based Natural Resource Management. World Development, Vol. 27, No.2, 225-247. 
Menell, P. S., \& Meurer, M. J. (2013). Notice Failure And Notice Externalities. The John M. Olin Center for Law, Economics and Business, pp 1-59.

Miandy, F., \& Arifin, H. S. (2007 ). Rencana Pengembangan dan Pengelolaan Lanskap Kawasan Obyek Wisata Danau Kerinci, Kabupaten Kerinci, Jambi. Jurnal Lanskap Indonesia| Vol 3 No 1, pp 46-52.

Miller, E. A., \& Banaszak-Holl, J. (2005). Cognitive and Normative Determinants of State Policymaking Behavior: Lessons. The Jouranl of Federalism, 191-216.

Ministry of Forestry. (2004). Peraturan Menteri Kehutanan Nomor P.19/Menhut-II/2004 tentang Kolaborasi Pengelolaan Kawasan Suaka Alam dan Kawasan Pelestarian Alam. Retrieved from http://ekowisata.org/wpcontent/uploads/2011/11/P_19_2004.pdf

Ministry of Forestry. (2006). Peraturan Menteri Kehutanan Nomor P.56/Menhut-II/2006 tentang Pedoman Zonasi Taman Nasional Menteri Kehutanan. Retrieved from http://ekowisata.org/wp-content/uploads/2011/11/P_56_20061.pdf

Ministry of Forestry. (2007). Peraturan Menteri Kehutanan Nomor P.03/MENHUT-II/2007 Tahun 2007. Retrieved from http://www.hukumonline.com/pusatdata/detail/lt54d97a918dee4/nprt/lt51f6625366f35 /peraturan-menteri-kehutanan-no-p.03_menhut-ii_2007-tahun-2007-organisasi-dantata-kerja-unit-pelaksana-teknis-taman-nasional

Miranda, L. (2012). The Role of International Law in Intrastate Natural Resource Allocation: Sovereignty, Human Rights, and Peoples-Based Development. Vanderbilt Journal of Transnational Law, Vol. 45, 785-840.

Mittermeier, R. A., Myers, N., Thomsen, J. B., Fonseca, G. A., \& Olivieri, S. (1998). Biodiversity Hotspots and Major Tropical Wilderness Areas: Approaches to Setting Conservation Priorities. Conservation Biology, Volume 12, Issue 3, 516-520.

Moeliono, M. W. (2009). The Decentralization of Forest Governance: Politics, Economics and the Fight for Control of Forest in Indonesian Borneo. (M. W. Moeliono, Ed.) London: Earthscan.

Moravia, H. (2009). Studi Arahan Wilayah Pengembangan Industri Pertanian sebagai Strategi Pembangunan Wilayah Kabupaten Kerinci. Skripsi. Bogor: Sekolah Pascasarjana, Institut Pertanian Bogor.

Muhtaman, D. R., \& Prasetyo, F. A. (2006). Forest Certification in Indonesia. In B. Cashore, F. Gale, E. Meidinger, \& D. Newsom, Confronting Sustainability: Forest Certification in Developing and Transitioning Countries (pp. pp 33-67). Yale Publishing Services Center.

Mulyana, A., Minnigh, P., Indriatmoko, Y., Limberg, G. U., Iwan, R., Saparuddin, \& Hamzah. (2010). KebijakanPengelolaan Zona Khusus; Dapatkah Meretas Kebuntuan dalam Menata Ruang Taman Nasional di Indonesia. BRIEF, 1-6. 
Mulyana, A., Moeliono, M., Minnigh, P., Indriatmoko, Y., Limberg, G., Utomo, N. A., . . . Hamzah. (2010, April 01). Establishing special use zones in national parks; Can it break the conservation deadlock in Indonesia? brief, pp. 1-6.

Muradian, R., Corbera, E., Pascual, U., Kosoy, N., \& May, P. H. (2010). Reconciling theory and practice: An alternative conceptual framework for understanding payments for environmental services. Ecological Economics 69, pp 1202-1208.

Murasman. (2009). Rencana Pembangunan Jangka Menengah Kabupaten Kerinci. Jambi: Pemerintah Kabupaten Kerinci.

Murniati, G. D. (2001). The Contribution of Agroforestry Systems to Reducing Farmer's Dependence on The Resources of Adjacent National Parks: A Case Study from Sumatra, Indonesia . Agroforestry System, Vol. 52, 171-184.

Mustalahti, I., \& Rakotonarivo, S. (2014). REDD+ and Empowered Deliberative Democracy: Learning from Tanzania from Tanzania. World Development Vol. 59, pp 199-211.

Myers, N., Mittermeier, R. A., Mittermeier, C. G., Fonseca, G. A., \& Kent, J. (2000, February 24). Biodiversity hotspots for conservation priorities. NATURE, pp. 853-858.

Myers, N., Mittermeier, R. A., Mittermeier, C. G., Fonseca, G. A., \& Kent, J. (2000, February 24). Biodiversity hotspots for conservation priorities. NATURE, Vol 403, pp. 853-858.

Myers, N., Mittermeier, R. A., Mittermeier, C. G., Fonseca, G. A., \& Kent, J. (2000, February 24). Biodiversity hotspots for conservation priorities. NATURE, Vol 403, pp. 853-858.

Natividad, J., \& Neidel, J. D. (2003). An Inside Look at the "Secret Valley". Sungai Penuh: Pemerintah Kabupaten Kerinci.

Naughton-Treves, L., Holland, M. B., \& Brandon, K. (2005). The Role of Protected Areas in Conserving Biodiversity and Sustaining Local Livelihood. Annual Review of Environment and Resources, Vol. 30, 219-252.

Nelson, E., Mendoza, G., Regetz, J., Polasky, S., Tallis, H., Camero, D. R., Shaw, M. R. (2009). Modeling multiple ecosystem services, biodiversity conservation, commodity production, and tradeoffs at landscape scales. The Ecological Society of America 7, 411.

North, D. C. (1990). Institutions, Institutional Change and Economic Performance. Cambridge University Press, Cambridge, UK.

Novra, A. (2007). Dampak Alokasi Pengeluaran Pemerintah Daerah Terhadap Deforestasi Kawasan dan Degradasi Taman Nasional Kerinci Seblat, Disertasi. Bogor: Sekolah Pasca Sarjana, Institut Pertanian Bogor.

Nugraha, R. T., \& Sugardjito, J. (2009). Assessment and management options of human-tiger conflicts in Kerinci Seblat National Park, Sumatra, Indonesia. Mammal Study 34, 141154. 
Nurrochmat, D. R., Darusman, D., \& Ruchjadi, D. (2014). Rekonstruksi Sistem Tenurial Kehutanan. Risalah Kebijakan Pertanian dan Lingkungan, 24-29.

Nurrochmat, D. R., Darusman, D., \& Ruchjadi, D. (2014). Rekonstruksi Sistem Tenurial Kehutanan. Risalah Kebijakan Pertanian dan Lingkungan, Vol. 1 No.1, 24-29.

Olson, J. M., Roese, N. J., Meen, J., \& Robertson, D. J. (1995). The Precondition and Consequencies of Relative Depriviation: Two Field Studies. Journal of Applied Social Psycology, 25,11, pp 944-964.

Olson, M. (1965). The Logic Of Collective Action: Public Goods and the Theory of Groups. Cambridge: Harvard University Press.

Olsson, P., \& Folke, C. (2004). Adaptive Comanagement for Building Resilence in SocialEcological System. Environmental Management, Vol.34, No. 1, 75-90.

Olsson, P., Folke, C., \& Berkes, F. (2004). Adaptive Comanagement for Building Resilience in Social-Ecological Systems. Environmental Management Vol. 34, No. 1, pp. 75-90.

Orams, M. B. (2002). Feeding wildlife as a tourism attraction: a review of issues and impacts. Tourism Management 23, 281-293.

Ostrom, E. (1990). Governing The Commons The evolution of institutions for collective action . Cambridge, United Kingdom : Cambridge University Press.

Ostrom, E. (1999). Collective Action and The Evolution of Social Norms. Workshop in Political Theory and Policy Analysis Center for the Study of Institutions, Population, and Environmental Change (pp. pp 1-44). Bloomington: Indiana University, Bloomington .

Ostrom, E. (2005). Understanding Institutional Diversity. The United States of America: Princeton University Press.

Ostrom, E. (2011). Background on The Institutional Analysis and Development Framework. Policy Stuides Journal, Vol. 39, No.1, 7-358.

Pambagio, A. (2016, April 10). http://news.detik.com/. Retrieved from http://news.detik.com/: http://news.detik.com/kolom/3165029/terobosan-kebijakan-pariwisata-indonesiakasus-danau-toba

Papadopolous, Y., \& Warin, P. (2007). Are innovative, participatory and deliberative procedures in policy making democratic and effective? European Journal of Political Research 46, pp 445-472.

Pearson, L. J., \& Dare, M. (2014). Co-management of protected areas: an opportunity for all? Australia New Zealand Society for Ecological Economics 2013 Conference. Canberra, Australia.

Peluso, N. L. (1995). Whose Woods Are These? Counter-Mapping Forest Territories in Kalimantan, Indonesia. Antipode 27,4, pp 383-406. 
Perdana, P. P. (2013, December 14). http://nationalgeographic.co.id/. Retrieved from http://nationalgeographic.co.id/:

http://nationalgeographic.co.id/berita/2013/12/indonesia-saat-ini-miliki-lima-tamanbumi

Peter A. Hall, Rosemary C.R. Taylor. (1996, May 9). Political sciences and The Three New Institutionalisms. MPIG Discussion Paper.

Pfaff, A., Robalino, J., Lima, E., Sandoval, C., \& Herrera, L. D. (2014). Governance, Location and Avoided Deforestation from Protected Areas: Greater Restrictions Can Have Lower Impact, Due to Differences in Location. World Development Vol. 55, pp. $7-20$.

Phalan, B., Bertzky, M., Butchart, S. H., Donald, P. F., Scharlemann, J. r., Stattersfield, A. J., \& Balmford, A. (2013). Crop Expansion and Conservation Priorities in Tropical Countries. PLoS ONE 8(1), 1-13.

Phelps, J., Webb, E. L., \& Agrawa, A. ( 2010 , April 16). Does REDD+ Threaten to Recentralize Forest Governance? SCIENCE Vol 328 , pp. pp 312-313.

Pinkerton, E. W. (1994). Local Fisheries Co-management: A Review of International Experiences and Their Implications for Salmon Management in British Columbia . Sci. 51, pp 2363-2378.

Pomeroy, R. S., \& Berkes, F. (1997). Two to tango: the role of government in fisheries comanagement . Marine Policy, Vol. 21, No. 5, pp. 465-480.

Pomeroy, R. S., McConney, P., \& Mahon, R. (2004). Comparative analysis of coastal resource co-management in the Caribbean. Ocean \& Coastal Management 47, pp $429-447$.

Powel, B., Ickowitz, A., McMullin, S., Jamnadass, R., Padoch, C., Pinedo-Vasquez, M., \& Sunderland, T. (2013). The Role of Forests, Trees and Wild Biodiversity for NutritionSensitive Food Systems and Landscapes. Bogor-Indonesia \& Nairobi-Kenya: CIFOR \& ICRAF.

Pretty, J. (2003, December 12). Social Capital and the Collective Management of Resources. SCIENCE, Vol 302, pp. pp 1912-1914.

Pretty, J., Toulmin, C., \& Williams, S. (2011). Sustainable intensification in African agriculture. International Journal of Agricultural Sustainability, 9:1, pp 5-24.

Purwandana, D., Ariefiandy, A., Imansyah, M. J., Rudiharto, H., Seno, A., Ciof, C., . . . Jessop, T. S. (2014). Demographic status of Komodo dragons populations in Komodo National Park. Biological Conservation 171, 29-35.

Purwanti, F. (2008). Konsep Co-management Taman Nasional Karimun Jawa. Bogor: Sekolah Pascasarjana-IPB. 
Purwanto, S. A. (2005). Taman Nasional, Hak-hak Masyarakat Setempat dan Pembangunan Regional. Antropology Indonesia Vol. 29, No. 3, pp 269-288.

Qodri, H. (2001). Hukum Adat Sakti Alam Kerinci; Suatu Pedoman dan Ico Pakai di Tigo Luhah Siulak Tanah Sekudung. Sungai Penuh.

R.S. Defries, J. R. (2008). Agricultural Intensification Increases Deforestation Fire Activity in Amazona. Global Change Biology, 2262-2275.

Raymond E., P. C. (2007, May 18). Tropical Forest and Climate Policy. Science, pp. 985-986.

Reid, W. V. (1998, July 1). Biodiversity hotspots. Trends in Ecology \& Evolution, Volume 13, Issue 7, pp. 275-280.

Reinius, S. W., \& Fredman, P. (2007). Protected Areas as Attraction. Annals of Tourism Research, Vol. 34, No. 4, 839-854.

Republic of Indonesia. (1990). Undang-Undang Republik Indonesia Nomor 5 Tahun 1990 tentang Konservasi Sumberdaya Alam Hayati dan Ekosistemnya. Retrieved from http://search.hukumonline.com/id/search/browse?q=UU+nomor+5+tahun++1990+

Republic of Indonesia. (1999). Undang-Undang Republik Indonesia Nomor 41 Tahun 1999 tentang Kehutanan. Retrieved from http://www.hukumonline.com/pusatdata/download/lt4f196a25e3d3c/node/254: http://www.hukumonline.com/pusatdata/download/lt4f196a25e3d3c/node/254

Republic of Indonesia. (2011). Peraturan Pemerintah Republik Indonesia tentang Pengelolaan Kawasan Suaka Alam dan Kawasan Pelestarian Alam. Retrieved from https://www.minerba.esdm.go.id/library/sijh/PP\%2028\%20thn\%202011.pdf

Republic of Indonesia. (1999). Peraturan Pemerintah Republik Indonesia Nomor 7 Tahun 1999 tentang Pengawetan Jenis Tumbuhan dan Satwa. Retrieved from file://D:/Download\%20Doni/ppno7th1999ttgpengawetanjenistumbuhandansatwa.pdf

Ridwansyah, M. (2007). Evaluasi Ekonomi Penggunaan Lahan Eks-Areal Hutan Konsesi di Sekitar Daerah Penyangga Taman Nasional Kerinci Seblat, Disertasi. Bogor: Sekolah Pascasarjana, Institut Pertanian Bogor.

Robinson, B. E., Holland, M. B., \& Naughton-Treves, L. (2014). Does secure land tenure save forests? A meta-analysis of the relationship between land tenure and tropical deforestation. Global Environmental Change 29, pp 281-293.

Rodrugues, A. S., Andelman, S. J., Bakarr, M. I., Boltani, L., Brooks, T. M., Cowling, R. M., $\&$ al., e. (2004, April 8). Effectiveness of the global protected area network in representing species diversity. NATURE, pp. 640-643.

Rotich, D. (2012). Concept of Zoning Management in Protected Areas. Journal of Environment and Earth Science, Vol 2, No.10, 173-183.

Sabatier, P. A., Leach, W. D., Lubbel, M., \& Pelkey, N. W. (2005). Theoritical Frameworks Explaining Partnership Success. In P. A. Sabatier, W. Focht, M. Lubel, Z. 
Trachtenberg, A. Vedlitz, \& M. Matlock, Swimming Upstream; Collaborative Approach to Watershed Management (pp. 173-199). Cambridge: The MIT Press.

Sandelowski, M. (1995). Qualitative Analysis: What It Is and How to Begin. Research in Nursing \& Health, 371-375.

Sandström, C. (2009). Institutional Dimensions of Comanagement: Participation, Power, and Process. Society and Natural Resources, 22, 230-244.

Satu Elo, H. K. (2008). The Qualitative Content Analysis Process. Journal of Advanced Nursing, 17-115.

Saunders, D. M. (2002). Freshwater Protected Areas: Strategies for Conservation. Conservation Biology, Vol. 16, No.1, 30-41.

Sayer, J. S. (2012). Ten Principles for A Landscape Approach to Reconciling Agriculture, Conservation, and Other Competing Land Uses. PNAS, Vol. 10, No. 21, 8349-8356.

Schusler, T. M., Decker, D. J., \& Pfeffer, M. J. (2003). Social Learning for Collaborative Natural Resource Management. Society \& Natural Resources, 15, 309-326.

Schusser, C., Krott, M., Logmani, J., Sadath, N., Movuh, M. C., \& Salla, M. (2013). Community Forestry in Germany, a Case Study Seen Through the Lens of the International Model. Journal of Sustainable Development; Vol. 6, No. 9, pp 88-100.

Schwartzman, S. N. (2000). Arguing Tropical Forest Conservation: People versus Parks. Conservation Biology, Vol. 14, No. 5, 1370-1374.

Schwartzman, S., Moreira, A., \& Nepstad, D. (2000). Rethinking Tropical Forest Conservation: Perils in Parks. Conservation Biology, Vol. 14, No. 5, 1351-1357.

Schwarze, S., Schippers, B., Weber, R., Faust, H., Wardhono, A., Zeller, M., \& Kreise, W. (2007). Forest Products and Household Incomes: Evidence from Rural Households Living in the Rainforest Margins of Central Sulawesi. Springer Verlag Berlin 2007, pp 209-224.

Secco, L., Re, R. D., Pettenella, D. M., \& Gatto, P. (2014). Why and how to measure forest governance at local level: A set of indicators. Forest Policy and Economics 49, pp 5771.

Sekretariat DPRD Kabupaten Kerinci. (2011). Penetapan Ibu Kota Kabupaten Kerinci Provinsi Jambi. Sungai Penuh: DRPD Kabupaten Kerinci.

Selfa, T., \& Endter-Wada, J. (2008). The Politics of Community-Based Conservation in Natural Resource Management: A Focus for International Comparative Analysis. Environment and Planning A, 948-965.

Shafer, C. L. (1999). National Park and Reserve Planning to Protect Biological Diversity: Some Basic Elements. Landscape and Urban Planning, 44, 123-153. 
Simberloff, D., Martin, J.-L., Genoves, P., Maris, V., Wardle, D. A., Aronson, J., Vila, M. (2013). Impacts of biological invasions: what's what and the way forward. Trends in Ecology \& Evolution, Vol. 28, No. 1, pp 58-66.

Singleton, S. (2000). Cooperation or Capture? The Paradox of Comanagement and Community Participation in Natural Resource Management and Environmental Policymaking. Environmental Politics, Volume 9, Issue 2, pp 1-21.

Sloan, S., Jenkins, C. N., Joppa, L. N., Gaveau, D. L., \& Laurance, W. F. (2014). Remaining natural vegetation in the global biodiversity hotspots. Biological Conservation 177, $12-24$.

Smith, T. B., Kark, S., Schneider, C. J., Wayne, R. K., \& Moritz, C. (2001, August 1). Biodiversity hotspots and beyond: the need for preserving environmental transitions. TRENDS in Ecology \& Evolution Vol.16 No.8, p. 431.

Sodhi, N. L. (2004). Southeast Asian Biodiversity: An Impending Disaster. Trends in Ecology and Evolution, Vol. 19, No. 12, 654-660.

Sodhi, N. L. (2010). Conserving Southeast Asian Forest Biodiversity in Human-Modified Landscape. Biological Conservation 143, 2375-2384.

Statistics of Kerinci Regency. (2013). Kerinci Dalam Angka 2013. Sungai Penuh: Statistics of Kerinci Regency.

Steve Selin, D. C. (1995). Developing a Collaborative Model for Environmental Planning and Management. Environmental Management.

Stibig, H.-J., Achard, F., Carboni, S., Raši, R., \& Miettinen, J. (2014). Change in tropical forest cover of Southeast Asia from 1990 to 2010. Biogeosciences, 11, pp 247-258.

Stone, M. J. (2002). Ecotourism \& Community Development: Case Studies From Hainan, China. Waterloo, Ontario, Canada: the University of Waterloo.

Stringer, L. C., Dougill, A. J., Fraser, E., Hubacek, K., Prell, C., \& Reed, M. S. (2006). Unpacking "Participation" in the Adaptive Management of Social-ecological Systems: a Critical Review. Ecology and Society 11(2): 39.

Stuart J. Davies, L. U. (1999). Smoke-haze from the 1997 Indonesian Forest Fires: Effects on Pollution levels, Local Climate, Atmospheric CO2 Concentrations, and Tree Photosynthesis. Forest Ecology and Management 124, 137-144.

Sugardjito, J., Boekhorst, I. J., \& Hooff, J. A. ( 1987 ). Ecological Constraints on the Grouping of Wild Orang-utans (Pongo pygmaeus) in the Gunung Leuser National Park, Sumatra, Indonesia . International Journal of Primatology, VoL 8, No. 1, 17-41.

Suharjito, D., \& Putro, H. R. (2013). Peran Ilmu Pengetahuan dalam Pembangunan Kehutanan Indonesia. In D. S. Suharjito, \& H. R. Putro, Pembangunan Kehutanan Indonesia Baru: Refleksi dan Inovasi Pemikiran (pp. 3-6). Bogor: IPB Press. 
Suhendang, E. (2013). Perkembangan Paradigma Kehutanan. In D. S. Suharjito, \& H. R. Putro, Pembangunan Kehutanan Indonesia Baru: Refleksi dan Inovasi Pemikiran (pp. 9-49). Bogor: IPB Press.

Sukardi, D. S. (2006). Melestarikan Pertumbuhan Ekonomi, Penghidupan Pedesaan, dan Manfaat Lingkungan. The World Bank: Washington D.C.

Sunderlin, W.D., Angelsen, A., Belcher, B., Burgers, P. Nasi, R., Santoso, L., \& Wunder, S. (2005). Livelihoods, Forests, and Conservation in Developing Countries: An Overview. World Development Vol. 33, No. 9, pp 1383-1402.

Sunderlin, W.D., Larson, A.M., Duchelle, A.E., Resosudarmo, I.A., \& Awono, A. (2014) How are REDD+ Proponents Addressing Tenure Problems? Evidence from Brazil, Cameroon, Tanzania, Indonesia, and Vietnam. World Development Vol. 55, pp. 37-52.

Supriatna, J. (2013). Berwisata Alam di Taman Nasional. Jakarta: Pustaka Yayasan Obor Indonesia.

Syaf, S. (2012). Pembentukan Identitas Etnik dalam Arena Ekonomi Politik Lokal di Era Desentralisasi (Pergulatan Politik Identitas Etnik di Kendari, Sulawesi Tenggara), Disertasi. Bogor: Sekolah Pascasarjana, Institut Pertanian Bogor.

Tedlock, B. (1991). From Participant Observation to the Observation of Participation: The Emergence of Narrative Ethnography. Journal of Anthropological Research, Vol. 47, No. 1, 69-94.

The KSNP Authority. (2014). Laporan Tahunan Balai Besar TNKS tahun 2013. Sungai Penuh: Balai Besar TNKS.

The World Bank. (2003). Rural Development and Natural Resources Sector Unit Indonesia Country Unit East Asia and Pacific Regional Office. Indonesia: World Bank.

The World Bank. (2006). Sustaining Economic Growth, Rural Livelihoods, and Environmental Benefits: Strategic Options for Forest Assitance in Indonesia. Washington, D.C.: The World Bank.

Tokuda, M., \& Yukawa, J. (2007). Biogeography and Evolution of Gall Midges (Diptera: Cecidomyiidae) Inhabiting Broad-Leaved Evergreen Forests in Oriental and eastern Palearctic Regions. Oriental Insects, Vol. 41, pp 121-139.

Tomićević, J., Shannon, M. A., \& Milovanović, M. (2010). Socio-economic impacts on the attitudes towards conservation of natural resources:Case study from Serbia. Forest Policy and Economics; Vol.12, 157-162.

Tourism Office of Kerinci Regency. (2014). Potensi Pariwisata Kabupaten Kerinci. Singai Penuh: Dinar Pariwisata Kabupaten Kerinci.

Tscharntke, T., Clough, Y., Bhagwat, S. A., Buchori, D., Faust, H., Hertel, D., Wanger, T. C. (2011). Multifunctional shade-tree management in tropical agroforestry landscapes - a review. Journal of Applied Ecology 48, pp 619-629. 
Vedeld, P., Jumane, A., Wapalila, G., \& Songorwa, A. (2012). Protected areas, poverty and conflicts A livelihood case study of Mikumi National Park, Tanzania. Forest Policy and Economics 21, pp 20-31.

Verbist, B., Putra, A. E., \& Budidarsono, S. (2005). Factors driving land use change: Effects on watershed functions in a coffee agroforestry system in Lampung, Sumatra. Agricultural Systems 85, pp 254-270.

Verhoef, E. (1994). External Effects and Social Costs of Road Transport. Transpn. R\&-A. Vol. 28A, No. 4, pp 273-28.

Vodouhê, F. G., Coulibaly, O., Adégbidi, A., \& Sinsin, B. (2010). Community perception of biodiversity conservation within protected areas in Benin. Forest Policy and Economics 12, 505-512.

Vodouhê, F. G., Coulibaly, O., Adégbidi, A., \& Sinsin, B. (2010). Community perception of biodiversity conservation within protected areas in Benin. Forest Policy and Economics, Volume 12, Issue 7, pp 505-512.

Wahyuni, N. I., \& Mamonto, R. (2012). Persepsi Masyarakat Terhadap Taman Nasional dan Sumberdaya Hutan: Studi Kasus Blok Aketawaje, Taman Nasional Aketawaje Lolobata (Communities Perception toward National Park and Forest Resources: Case Study at Aketajawe Block, Aketajawe Lolobata National Pa. Info BPK Manado Volume 2 No 1, pp 1-16.

Wallace, G. N., \& Pierce, S. M. (1996). An Evaluation of Ecotourism in Amazonas, Brazil. Annolr of Tourism Research, Vol. 23, No. 4, pp 843-873.

Walpole, M. J., \& Goodwin, H. J. (2000). Local Economic Impacts of Dragon Tourism in Indonesia. Annals of Tourism Research, Vol. 27, No. 3, pp 559-576.

Weaver, D. B. (2001). The encyclopedia of ecotourism. London, UK: CAB International.

Weaver, D. B., \& Lawton, L. J. (2007). Twenty years on: The state of contemporary ecotourism research. Tourism Management 28, pp 1168-1179.

Weeks, R., Aliño, P. M., Atkinson, S., II, P. B., Binson, A., Campos, W. L., . . . Lynett. (2014). Developing Marine Protected Area Networks in the Coral Triangle: Good Practices for Expanding the Coral Triangle Marine Protected Area System. Coastal Management, 42, pp 183-205.

Werner, S. (2001). Environmental Knowledge and Resource Management: Sumatra's Kerinci-Seblat National Park. Berlin: Technischen Universität Berlin .

West, P. I. (2006). Parks and Peoples: The Social Impact of Protected Areas. Annual Review of Anthropology, Vol. 35, 251-265.

West, P., Igoe, J., \& Brockington, D. (2006). Parks and Peoples: The Social Impact of Protected Areas. The Annual Review of Anthropolog, 35, 251-77. 
White, A. T., Aliño, P. M., Cros, A., Fatan, N. A., Green, A. L., Teoh, S. J., . . . Wen, W. (2014). Marine Protected Areas in the Coral Triangle: Progress, Issues, and Options, Coastal Management. Coastal Management 42:2, pp 87-106.

White, A., \& Martin, A. (2002). Who owns the world's forests? forest tenure and public forests in Trantition. Washington, D.C.: Center for International Environmental Law.

Wicke, B., Sikkema, R., Dornburg, V., \& Faaij, A. (2011). Exploring land use changes and the role of palm oil production in Indonesia and Malaysia. Land Use Policy $28, \mathrm{pp}$ 193-206.

Widianto, H. (2016, April 10). http://www.pikiran-rakyat.com/. Retrieved from http://www.pikiran-rakyat.com/wisata/2016/01/26/358547/kejar-target-20-jutawisman-pariwisata-percepat-akselerasi: http:/www.pikiranrakyat.com/wisata/2016/01/26/358547/kejar-target-20-juta-wisman-pariwisatapercepat-akselerasi

Williams, B. K. (2011). Adaptive Management of Natural Resources-Framework and Issues. Journal of Environmental Management 92, 1346-1353.

Wilson, C., \& Tisdell, C. (2001). Why farmers continue to use pesticides despite environmental, health and sustainability costs. Ecological Economics 39, pp 449-462.

Wilson, K. A., Meijaard, E., Drummond, S., Grantham, H. S., Boitani, L., Catullo, G., . . . Watts, M. (2010). Conserving biodiversity in production landscapes. Ecological Applications, Vol. 20, No. 6, 1721-1732.

Winberg, E. (2010). Participatory Forest Management in Ethiopia, Practices and Experiences. Addis Ababa: Food and Agriculture Organization, Sub Regional Office for Eastern Africa (SFE) .

Wiratno, Indriyo, D., Syarifudin, A., Kartikasari, A., \& Kartikasari, A. (2001). Berkaca d; Cerm;n Retak: Refleks; Konservas; dan ImpUkasi Bagi Pengelolaan Taman Nasional. FOReST Press, The Gibbon Foundation, and PILINGO Movement.

Wood, P., Sheil, D., Syaf, R., \& Warta, Z. (2014, May 1). The Implementation and Sustainability of Village Conservation Agreements Around Kerinci Seblat National Park, Indonesia. Society \& Natural Resources, 27:6, pp 602-620.

Wood, P., Sheil, D., Syaf, R., et al. (2014, May 1). The Implementation and Sustainability of Village Conservation Agreements Around Kerinci Seblat National Park, Indonesia. pp. 602-620.

Wunder, S., Engel, S., \& Pagiola, S. (2008). Taking stock: A comparative analysis of payments for environmental services programs in developed and developing countries. Ecological Economics 65, pp $834-852$.

Young, J. C., Jordan, A., Searle, K. R., Butler, A., Chapman, D. S., Simmons, P., \& Watt, A. D. (2013). Does stakeholder involvement really benefit biodiversity conservation? Biological Conservation158, 359-370. 
Young, J., Richards, C., Fischer, A., Halada, L., Kull, T., Kuzniar, A., . . W Watt, A. (2007). Conflicts between Biodiversity Conservation and Human Activities in the Central and Eastern European Countries. A Journal of the Human Environment, 36(7), pp 545550. 


\section{Declaration of originality and certificate of authorship}

I, Doni Yusri, hereby declare that I am the sole author of this dissertation entitled ''Perspectives of Sustainable-Collaborative Management: a Case Study in Kerinci Seblat National Park, Sumatra-Indonesia". All references and data sources that were used in the dissertation have been appropriately acknowledged. I furthermore declare that this work has not been submitted elsewhere in any form as part of another dissertation procedure. I certify that this dissertation written by me as the author.

Göttingen, June 2016 (Doni Yusri) 


\section{Acknowledgement}

First, I would like to express my gratitude and praise to God because the completion of this dissertation is a great gift from the Almighty. Second, I would like to thank several people from the depths of my heart, those who patiently and attentively kept pushing, supporting and motivating me to finish this dissertation. I realize that writing a dissertation is a journey full of challenges and tests. The following individuals have been very inspiring to me and are worthy of mention here.

First, Professor Heiko Faust who, with friendliness, sincerity and trust, has given me the opportunity to gain knowledge and has helped me immensely in completing this dissertation. Also, Professor Christoph Dittrich who has been patient and continued to support me in finishing this dissertation. I will never forget either of you.

Second, I would also like to give thanks and love to my wife, Heti Mulyati, and our angel, our beloved Zaneeta Aidha Khanza who have accompanied me on every step of the way and kept me smiling in my hard times.

Also to my friends and colleagues, I would like to thank you for the advice, input and motivation needed to get through studying and completing my dissertation.

Finally, I would like to thank my dissertation examiner committee for their willingness to read and take the time to provide feedback and constructive criticism. 
Appendix 1: List of the 50 National Parks in Indonesia

\begin{tabular}{|c|c|c|c|}
\hline \multirow{2}{*}{ No. } & National Park & \multirow{2}{*}{ Provinces } & \multirow{2}{*}{$\begin{array}{c}\text { Total Area } \\
\text { (Hectare) }\end{array}$} \\
\hline & (Taman Nasional/TM) & & \\
\hline 1 & TN Gunung Leuser & $\begin{array}{l}\text { Nanggroe Aceh Darussalam; } \\
\text { Sumatera Utara }\end{array}$ & $1,094,692$ \\
\hline 2 & TN Batang Gadis & Sumatera Utara & 108 \\
\hline 3 & TN Tesso Nilo & Riau & 83,068 \\
\hline 4 & TN Siberut & Sumatera Barat & $190,500.00$ \\
\hline 5 & TN Kerinci Seblat & \begin{tabular}{|l|} 
Sumatera Barat; Jambi; \\
Sumatera Selatan; Bengkulu
\end{tabular} & $1,375,349.867$ \\
\hline 6 & TN Bukit Dua Belas & Jambi & $60,500.00$ \\
\hline 7 & TN Bukit Tiga Puluh & Jambi; Riau & $144,223.00$ \\
\hline 8 & TN Berbak & Jambi & 162,7 \\
\hline 9 & TN Sembilang & Sumatera Selatan & $202,896.31$ \\
\hline 10 & TN Bukit Barisan Selatan & Bengkulu; Lampung & 365 \\
\hline 11 & TN Way Kambas & Lampung & $125,621.30$ \\
\hline 12 & TN Ujung Kulon & Banten & $120,956.00$ \\
\hline 13 & TN Kepulauan Seribu & DKI Jakarta & $107,489.00$ \\
\hline 14 & TN Gunung Halimun Salak & Jawa Barat; Banten & $113,357.00$ \\
\hline 15 & \begin{tabular}{|l|} 
TN Gunung Gede \\
Pangrango \\
\end{tabular} & Jawa Barat & $21,975.00$ \\
\hline 16 & TN Gunung Ciremai & Jawa Barat & $15,500.00$ \\
\hline 17 & TN Karimun Jawa & Jawa Tengah & $110,117.30$ \\
\hline 18 & TN Gunung Merbabu & Jawa Tengah & $5,725.00$ \\
\hline 19 & TN Gunung Merapi & Jawa Tengah; DI Yogyakarta & $4,567.93$ \\
\hline 20 & $\begin{array}{l}\text { TN Bromo Tengger } \\
\text { Semeru }\end{array}$ & Jawa Timur & $50,276.20$ \\
\hline 21 & TN Meru Betiri & Jawa Timur & $58,000.00$ \\
\hline 22 & TN Baluran & Jawa Timur & $25,000.00$ \\
\hline 23 & TN Alas Purwo & Jawa Timur & $43,420.00$ \\
\hline 24 & TN Bali Barat & Bali & $19,002.89$ \\
\hline 25 & TN Gunung Rinjani & Nusa Tenggara Barat & $41,330.00$ \\
\hline 26 & TN Komodo & Nusa Tenggara Timur & $132,572.00$ \\
\hline 27 & TN Manupeu Tanadaru & Nusa Tenggara Timur & $87,984.09$ \\
\hline 28 & TN Laiwangi Wanggameti & Nusa Tenggara Timur & $47,014.00$ \\
\hline 29 & \begin{tabular}{|l|} 
TN Kelimutu \\
\end{tabular} & Nusa Tenggara Timur & $5,356.50$ \\
\hline 30 & TN Gunung Palung & Kalimantan Barat & $90,000.00$ \\
\hline 31 & TN Danau Sentarum & Kalimantan Barat & $132,000.00$ \\
\hline 32 & TN Bukit Baka Bukit Raya & $\begin{array}{l}\text { Kalimantan Barat; Kalimantan } \\
\text { Tengah }\end{array}$ & 181,09 \\
\hline 33 & TN Betung Kerihun & Kalimantan Barat & $800,000.00$ \\
\hline 34 & TN Tanjung Puting & Kalimantan Tengah & $415,040.00$ \\
\hline
\end{tabular}




\begin{tabular}{|c|l|l|c|}
35 & TN Sebangau & Kalimantan Tengah & $568,700.00$ \\
\hline 36 & TN Kayan Mentarang & Kalimantan Timur & $1,360,500.00$ \\
\hline 37 & TN Kutai & Kalimantan Timur & $198,604.00$ \\
\hline 38 & $\begin{array}{l}\text { TN Bantimurung } \\
\text { Bulusaraung }\end{array}$ & Sulawesi Selatan & $43,750.00$ \\
\hline 39 & TN Taka Bonerete & Sulawesi Selatan & $530,765.00$ \\
\hline 40 & TN Rawa Aopa Watumohai & Sulawesi Tenggara & $105,194.00$ \\
\hline 41 & TN Wakatobi & Sulawesi Tenggara & $1,390,000.00$ \\
\hline 42 & TN Lore Lindu & Sulawesi Tengah & $217,991.18$ \\
\hline 43 & TN Kepulauan Togean & Sulawesi Tengah & $362,605.00$ \\
\hline 44 & $\begin{array}{l}\text { TN Bogani Nani } \\
\text { Wartabone }\end{array}$ & Sulawesi Utara; Gorontalo & $287,115.00$ \\
\hline 45 & TN Bunaken & Sulawesi Utara & $89,065.00$ \\
\hline 46 & TN Aketajawe Lolobata & Maluku Utara & $167,300.00$ \\
\hline 47 & TN Manusela & Maluku & $189,000.00$ \\
\hline 48 & TN Teluk Cendrawasih & Papua Barat & $1,453,500.00$ \\
\hline 49 & TN Lorentz & Papua & $2,450,000.00$ \\
\hline 50 & TN Wasur & Papua & $413,810.00$ \\
\hline
\end{tabular}

